

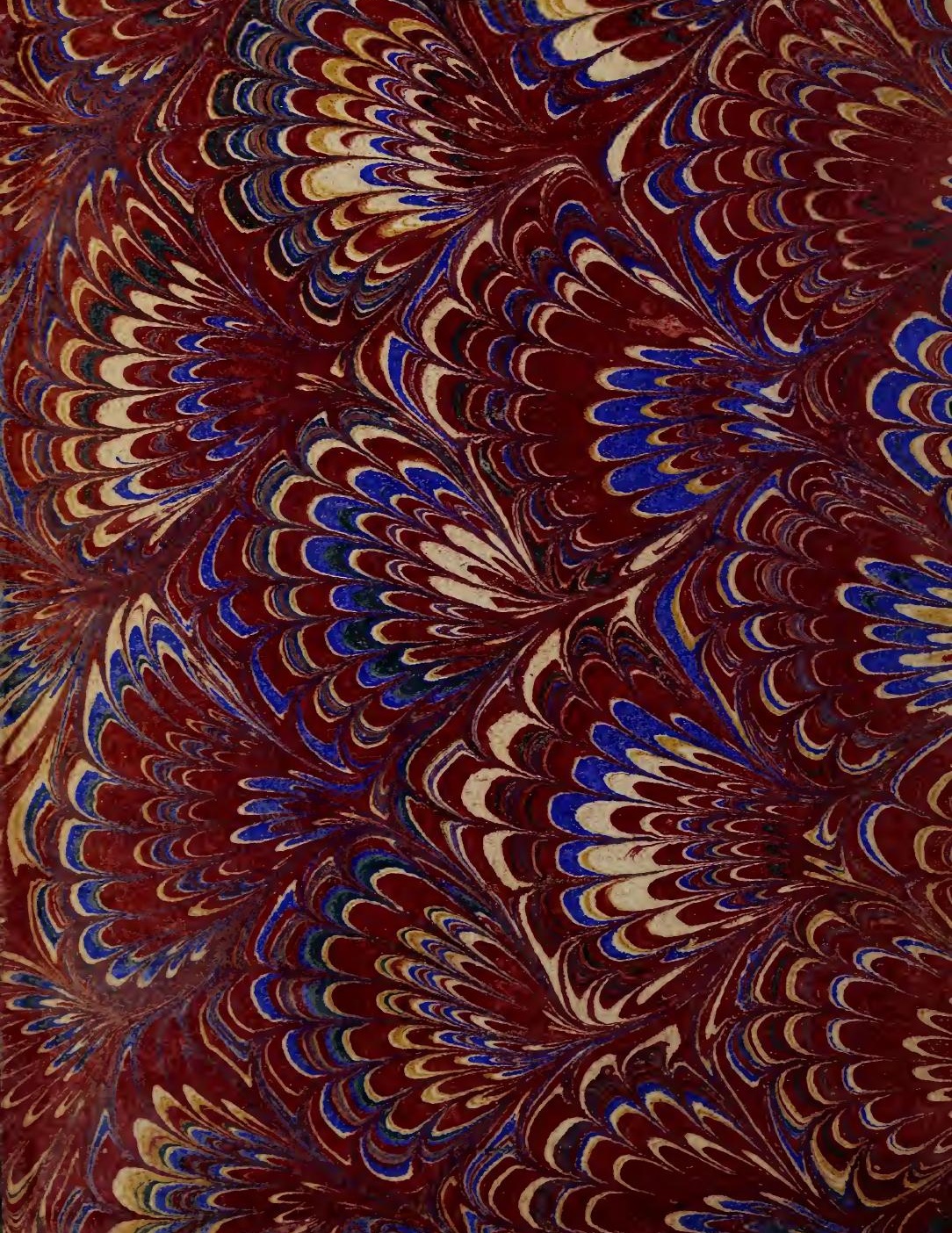

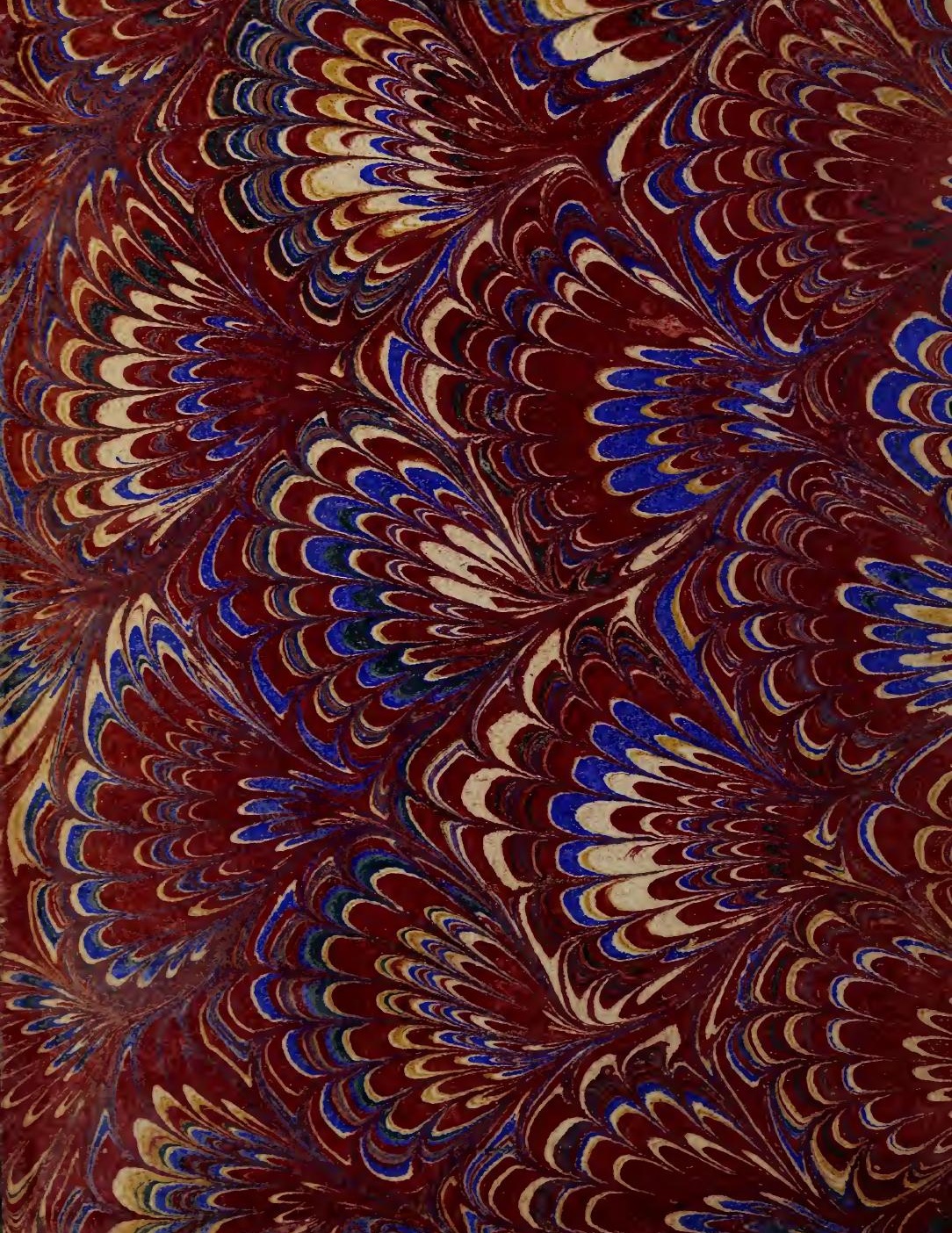

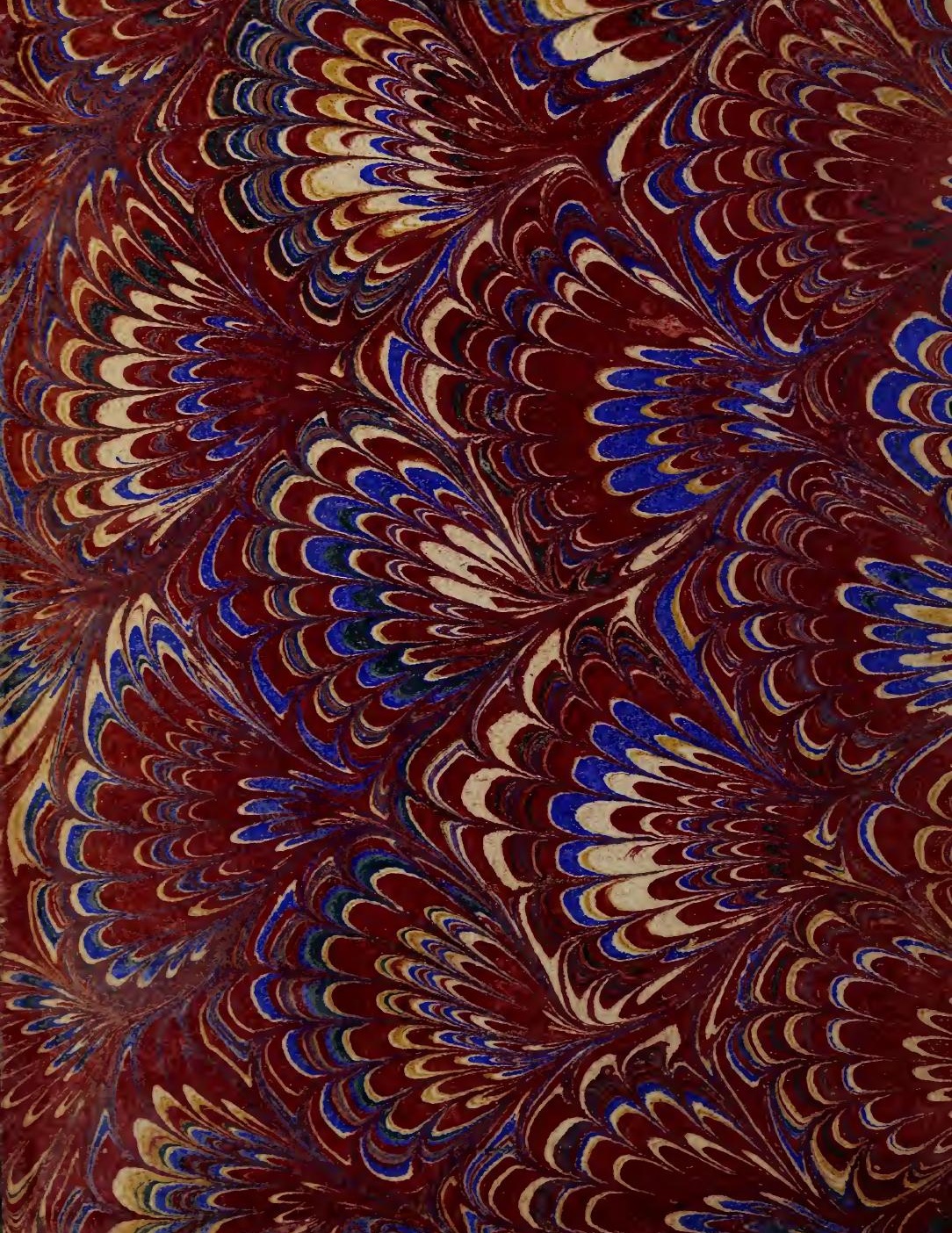
res recentery

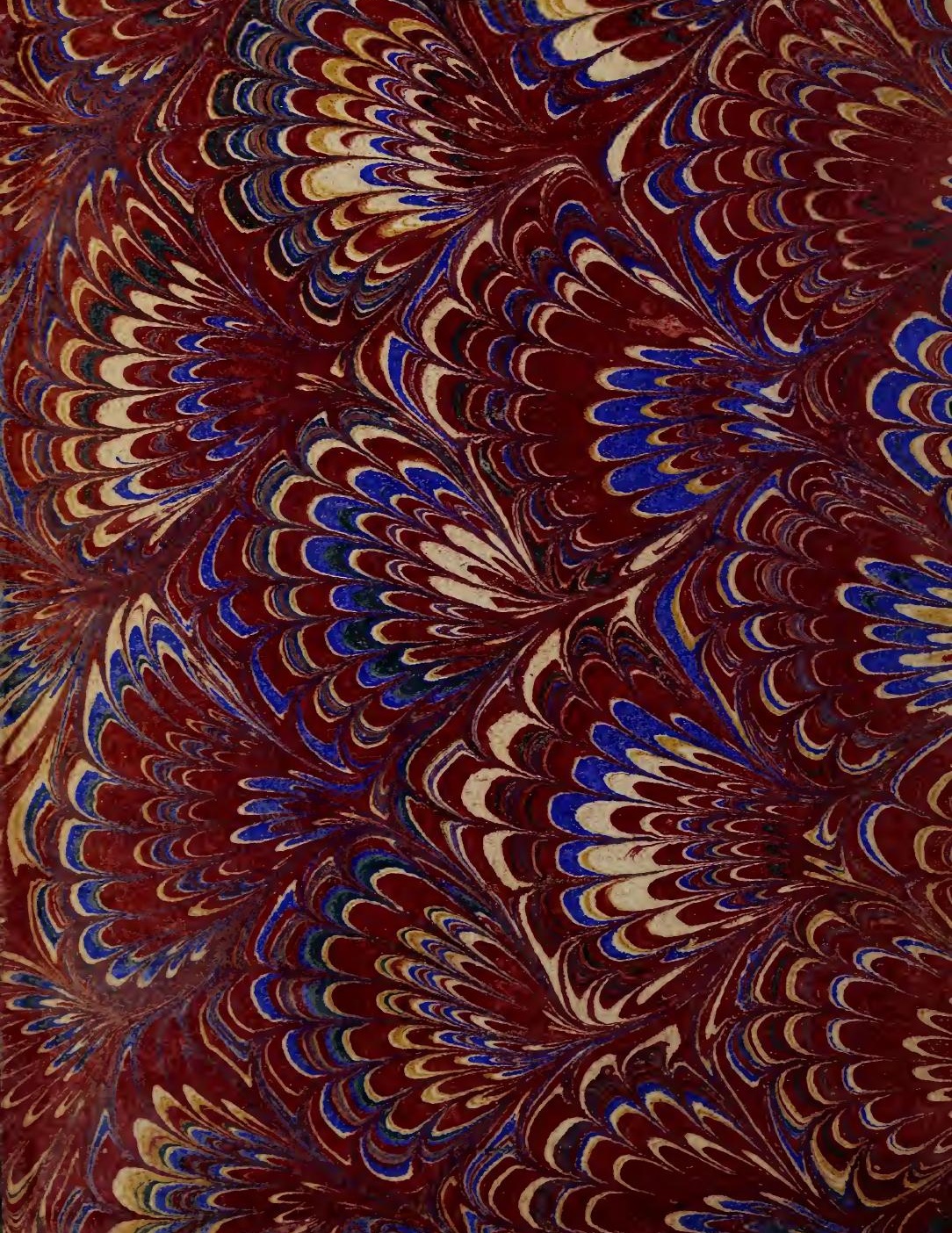
(cenes ce (t) 


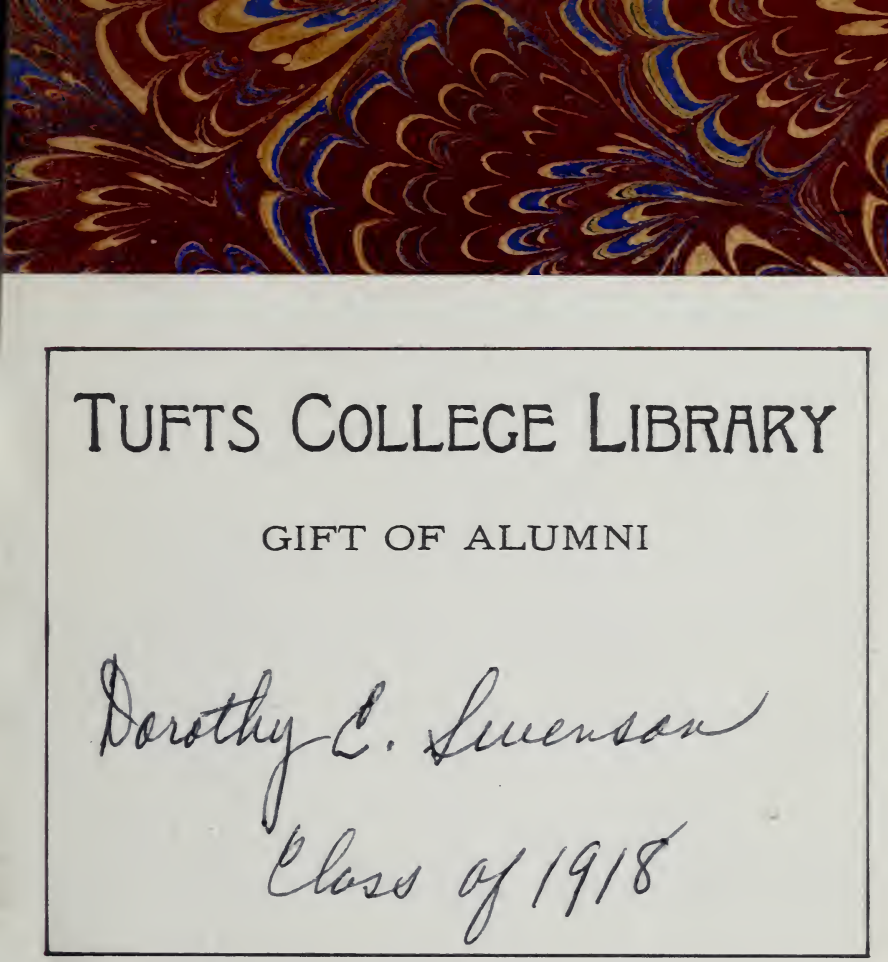

\section{TUFTS COLLEGE LIBRARY}

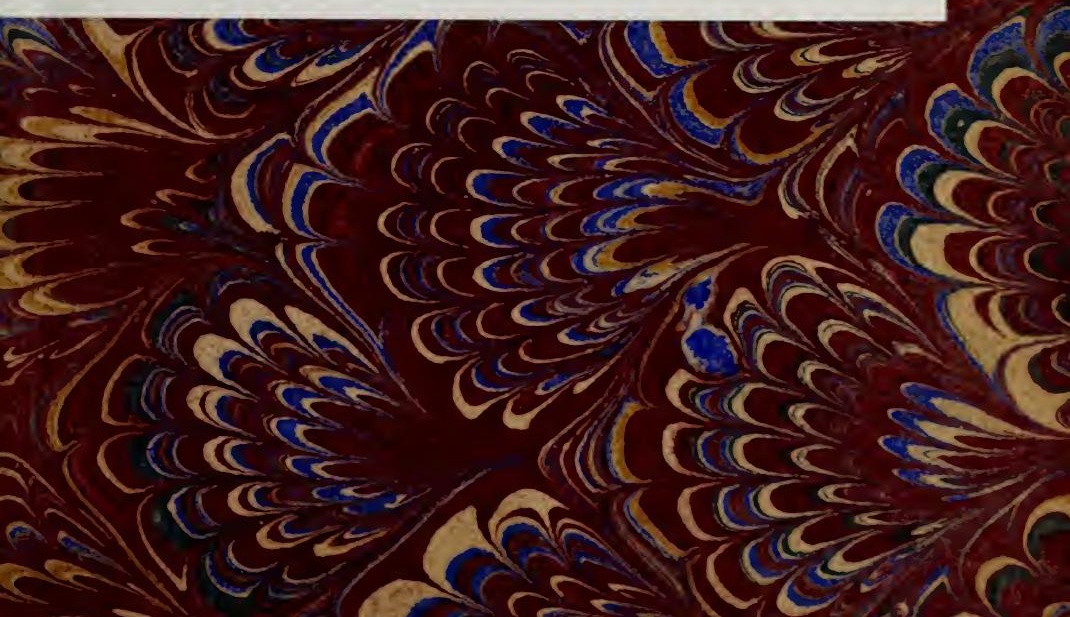




$$
x^{4}+1
$$






$$
26 \frac{159}{\frac{159}{70}}
$$




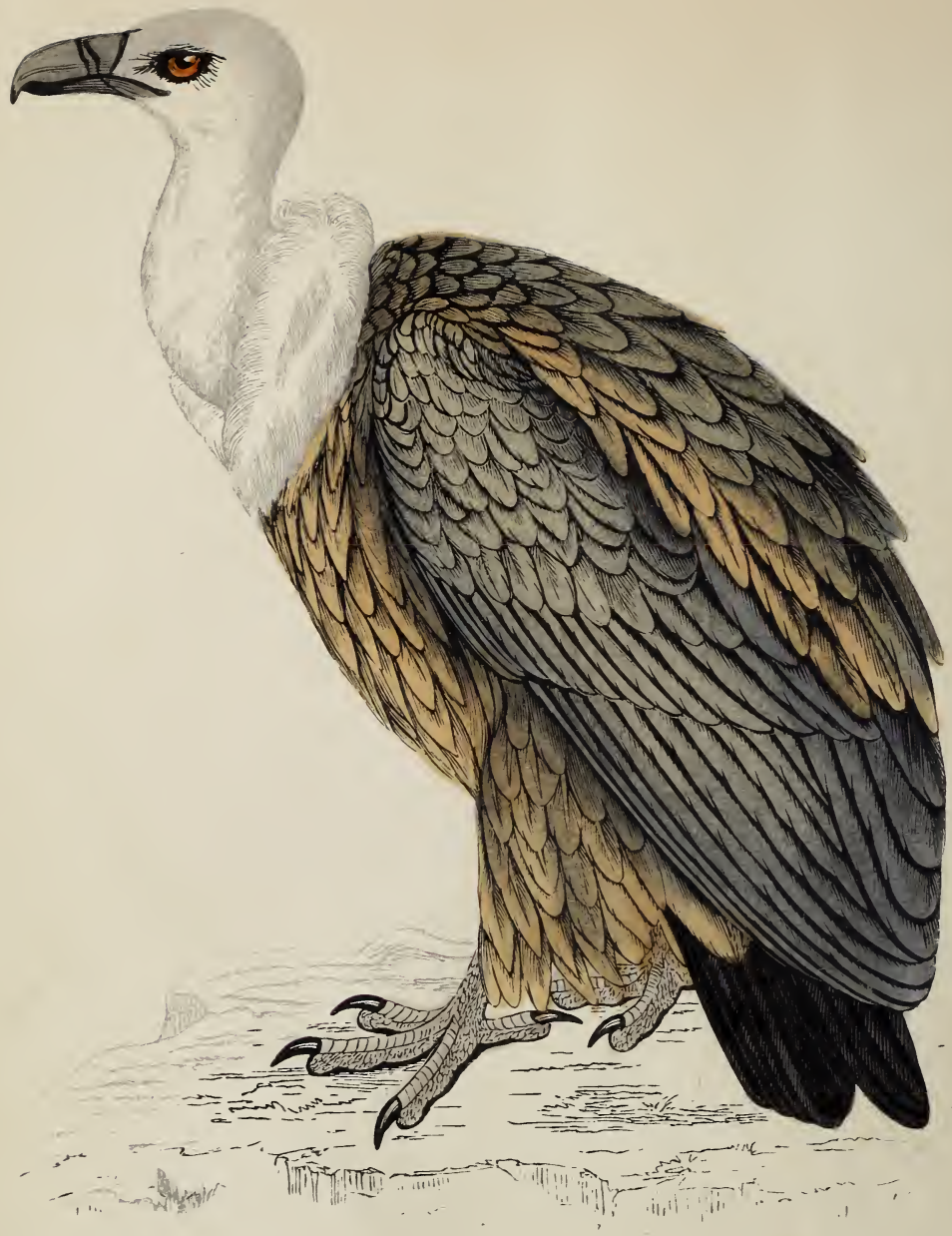



Digitized by the Internet Archive in 2013 


\section{H I S T O R Y}

$\mathrm{OF}$

\section{BRITISH BIRDS.}

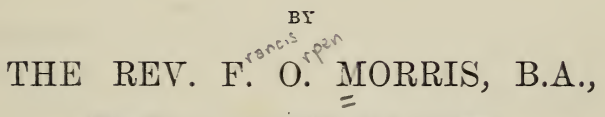

MEMBER OF THE ASHMIOLEAT SOCIETY.

VOL. I.

CONTAINING FORTY-THREE COLOURED ENGRATINGS.

'Gloria in excelsis Deo.'

I, $\mathrm{O} \mathrm{N} \mathrm{D} \mathrm{O} \mathrm{N} \mathrm{:}$

GROOMBRIDGE AND SONS, 5, PATERNOSTER ROW. 


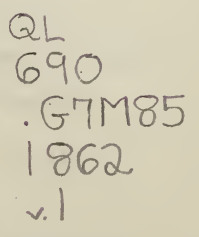




\section{O N T E N T S}

THE FIRST VOLUME.

Griffon Vulture .

Egyptian Vulture . . . . . . . . . 3

Erne • . . . . . . . . . 6

Golden Eagle. . . . . . . . . . 14

Spotted Eagle . . . . . . . . . . 21

Osprey . • . . . . . . . . . 23

Buzzard . . . . . . . . . . . 30

Rough-legged Buzzard . . . . . . . . 38

Honey Buzzard . . . . . . . . . 44

Kite . . . . . . . . . 52

Swallow-tailed Kite . . . . . . . . . 59

Jer-Falcon . . . . . . . . . 62

Peregrine . . . . . . . . . . 67

Hobby . . . . . . . . . . . 76

Orange-legged Hobby . . . . . . . . 81

Merlin . . . . . . . . . . . 85

Kestrel . . . . . . . . . . . . . . 92

Goshawk . . . . . . . . . . 103

Sparrow-Hawk . . . . . . . . . . 109

Marsh Harrier . . . . . . . . . 117

Hen Harrier . . . . . . . . 122 
Montagu's Harrier . . . . . . . . 127 Short-eared Owl . . . . . . . . . . 130 Long-eared Owl . . . . . . . . 134 Eagle Owl . . . . . . . . . . . 138 Scops-eared Owl . . . . . . . . . . 143 Snowy Owl . . . . . . . . . . . . 146 Tawny Owl . . . . . . . . . . . 151 White Owl . . . . . . . . . . 155 Little Owl . . . . . . . . . . . . 163 Tengmalm's Owl . . . . . . . . . 167 Mottled Owl * . . . . . . . . . 170 Hawk Owl . . . . . . . . . . 174 Great Shrike . . . . . . . . . 178 Red-backed Shrike . . . . . . . . . 182 Woodchat . . . . . . . . . . 187 Great Tit . . . . . . . . . . 190 Cole Tit . . . . . . . . . . . 194 Crested Tit . . . . . . . . . . 198 Blue Tit . . . . . . . . . . 202 Marsh Tit . . . . . . . . . . 210 Long-tailed Tit . $. \quad . \quad$. . . . . 214 Bearded Tit . . . . . . . . . . 219 


\section{HISTORY OF BRITISH BIRDS.}

\section{GRIFFON VULTURE.}

$\begin{array}{ll}\text { Gyps fulvus, } & \text { GRAY. } \\ \text { Gyps vulgaris, } & \text { SAvIGNY. } \\ \text { Vultur fulvus, } & \text { GOULD. }\end{array}$

Gyps--A Vulture. Fulvus--Yellow-tawny.

THE Griffon Vulture is an inhabitant of various parts of Europe, Asia, and Africa, regardless alike, seemingly, of cold and heat. It is met with in Turkey, Greece, the Tyrol, and Silesia; on the Alps and the Pyrenees; and is particularly abundant on both sides of the straits of Gibraltar, and as it has once been known, as presently mentioned, to visit this country, it may be hoped that it may again be met with here.

Like the rest of its congeners, this bird feeds on carrion, and thus performs a useful part in the economy of nature. Occasionally it will attack weak or sickly animals, but this is only as a 'dernier resort,' and when it cannot supply its appetite by the resources which are more natural to it. Thus, 'vice versâ,' the Eagle, whose congenial prey is the living animal, will, when forced by the extremity of hunger, put up with that food which under other circumstances it rejects, and leares for the less dainty Vulture.

When the Griffon meets with a plentiful supply of carrion, it continues feeding on it, if not disturbed, which it easily is by even the minor animals, until quite gorged, and then remains quiescent until digestion has taken place: if surprised in this condition, it is unable to escape by flight, and becomes an easy capture. It feeds its young, not by carrying food to them in its talons, as is the habit of the Eagles, Falcons, Hawks, and $\mathrm{Owls}$, but by disgorging from its maw part of what it had swallowed.

vol. 1 . 
Only one example of this grand addition to British ornithology has as yet occurred. A single specimen-an adult bird, in a perfectly wild state, was captured by a youth, the latter end of the year 1843, on the rocks near Cork harbour, and was purchased for half-a-crown for Lord Shannon, by whom, when it died, it was presented to the collection of the Dublin Zoological Society.

This species, also, like the rest of its kindred, possesses great powers of flight, though it is not rapid on the wing, and often soars upwards, almost always spirally, until it has become invisible to the human eye: it descends in the same manner in circles.

It builds its nest, as might be expected, on the highest and most inaccessible rocks, or sometimes on lofty trees, but in the winter it frequents more the lower and open grounds. The structure is three or four feet in diameter. The eggs, two or three in number, rather larger than those of a goose, of a dingy white colour, sometimes marked with a few pale red blots.

The length of this bird is about three feet eight inches. The bill is by some described as bluish lead-colour, by others, as yellowish white or horn-colour; the cere, bluish black; iris, reddish orange. The head and neck are covered with down, which, as well. as the ruff round the neck, and which is of the same material, is dull white; the eyes are margined with black. The upper and middle part of the breast also dull white, mixed with light brown, the lower part reddish yellow brown. The expansion of the wings eight feet. The back, and the wing coverts, light yellowish brown, the shafts light brown; the larger under wing coverts, dull white; lesser under wing coverts, light brown; primaries, dark brown; the tail the same colour. The legs and toes lead-colour, the former reticulated, the latter each with six large scales in front; the claws black.

The male and female are scarcely distinguishable, except in size-the former being smaller than the latter; as is the case generally with birds of prey; why, it is extremely difficult to say. Some reasons which have been advanced must at once be pronounced unsatisfactory.

Immature birds differ very considerably in plumage from those which have attained to the adult state: the former are much spotted all over, and the down on the head and neck is conspicuously marked with brown. 



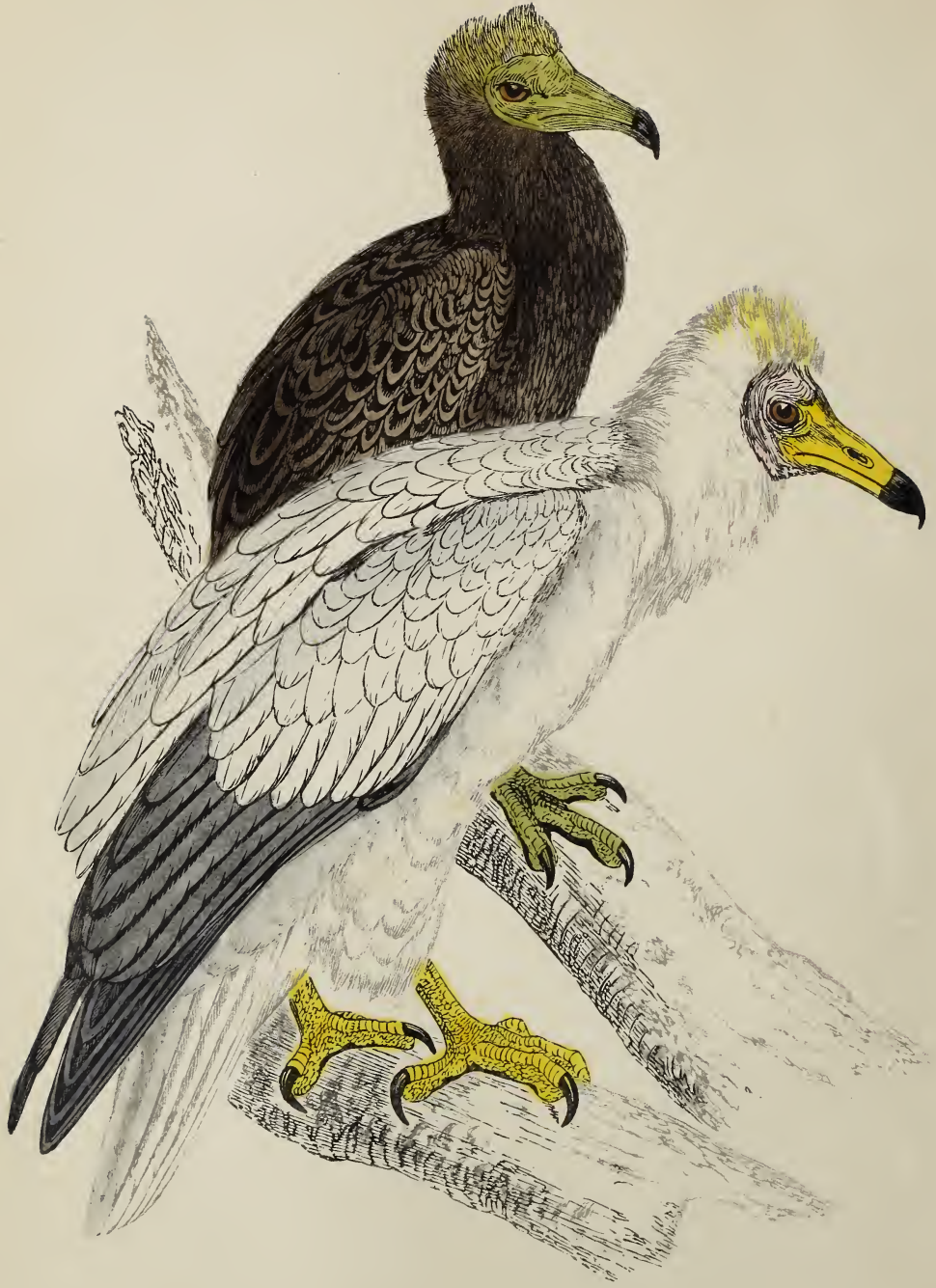






\section{EGYPTIAN VULTURE.}

\author{
Neophron percnopterus, \\ Vultur \\ Cathartes
}

SAVIGNY.

BEWICK.

TEMMINCK.

Neophron-Quære, ne-Intensitive, and Osphraino-To smell. Percnopterus, percos, or percnos-Black, or spotted with black. PteronA wing.

THIs species is, as might be gathered from its name, most numerous in Africa, being met with from the Isthmus of Suez to the Cape of Good Hope. It is also widely spread throughout Europe, being found in Spain, France, Italy, and Malta; in Turkey, very abundantly, in Switzerland, Norway, and other parts of this continent, as also in India; and has occurred, but only on one occasion, as mentioned below, in England. Perhaps the more cleanly state of our towns, as compared with the condition of those on the continent, may in some degree account for this unfrequency, as making its presence as unnecessary to us as uncongenial to itself.

Two specimens of this bird, supposed to be a pair, were observed in Somersetshire, near the shore of the Bristol Channel, in the month of October, in the year 1825-one of them was on the wing at the time, and was seen in the neighbourhood for a few days afterwards; the other was feeding on a dead sheep, and being either too hungry or too sated to be disposed to leare it, was easily approached sufficiently near to be shot. It was preserved, and came into the possession of the Rev. A. Matthew, of Kilre, in the before-named county.

The Egyptian Vulture, like others of its tribe, delights and rerels in the most decomposed carcases, the natural consequence of which is, a most disgusting odour from itself, and when dead it quickly putrefies. Occasionally it will feed on reptiles, by way perhaps of a more delicate meal, and on small animals; sometimes, through lack of other food, it will 'follow the plough,' for the sake of the worms and insects turned up by it, but its farourite haunt seems to be the sea-shore, where 
for the most part it finds its proper and legitimate sustenance in sufficient abundance.

As sefore obscrved, it is extremely abundant on the northern shores of Africa, but becomes gradually less frequent as the latitude becomes higher. It is held in much and deserved respect in those countries of which it is a denizen, as acting gratuitously, through a benevolent arrangement of Providence, the part of a scavenger, by devouring all decaying animal substances which would otherwise still further putrefy, and rapidly become fruitful sources, in these hot climates, of pestilence, disease, and death. Its habits in fact are those of the other Vultures, except that it is of a more timid character. It is occasionally seen in small flocks; and is sometimes tamed.

The Egyptian Vulture builds on high and inaccessible precipices, and lays from two to four eggs, which are generally white, or bluish white, but sometimes mottled a little with brown, and occasionally as much so as those of the Kestrel; they are widest in the middle, and taper towards each end.

It makes its nest about the end of March, and the young are hatched late in May, but remain in the nest until July, as they are not ready sooner to take flight.

The adult bird is about two feet seven inches in length. The base of the bill is bare of feathers, and of a pale fleshcolour; the space between the bill and the eyes is corered with a white down; iris, red; front of the crown and cheeks also bare of feathers, and flesh-coloured; back of the crown, feathered with a sort of crest, which the bird has the power of raising when in any way excited; throat bare of feathers, and flesh-coloured; the feathers on the lower part of the neck long and pointed. The whole of the rest of the plumage, white or yellowish white, with the exception of the greater quill feathers, which are black, and the bases of the secondaries, which are brown. The legs and toes are pale yellowish grey; the toes partially reticulated, the middle one having five scales, and the outer and hinder ones, three each; the outer and middle ones are united at the base; the claws black, and not strongly hooked, as in the Eagles, owing to the different use they are required for.

The female resembles the male, but is a little larger.

In the young bird the whole plumage is of a dull greyish brown, with yellowish spots on the tips of the feathers; the quills black, as in the adult. As it adrances in age, the dark parts of the plumage become of a rich purple brown. 
The following is the description of a yearling bird, the age, as is believed, of the specimen before spoken of:-Bill, of a dark horn-colour; cere, which is thickest at the base, and reaches over balf the length of the bill, jellow; iris, red; (Meyer says that at a jear old the iris is brown;) there are a few bristles on the edges of the bill, and between it and the eyes; crest, as in the adult bird. The head is covered with a bare skin of a deep reddish colour; the neck clothed with long hackle feathers, which form a kind of ruff of deep brown, tipped with cream-colour; and the nape with thick white down, interspersed with small black feathers. The chin has some tufts of hair beneath it. The back is cream white; the wings, fire feet six to fire feet nine inches in expanse; secondaries, palc brown, tipped and edged with jellowish white; larger wing corerts, deep brown, varied with cream white; lesser wing corerts, deep brown near the body, succeeded by lighter feathers, and these again by cream-coloured ones; tail, long and wedge-shaped; legs, yellowish grey; the middle toe has four scales on the last joint, and the outer and inner ones three each; the claws are blackish brown, and only slightiy curved. 


\section{ERNE.}

Haliëtus albicilla,
Falco
Aquila
SeLby.

Montagu. JENYNS.

( $H$ jals-The sea. Aietos-An Eagle. Alba-White, Cilla-A tail.

IF, beyond perhaps a kind of daring courage, and even this, most probably, the mere result of hunger, the Golden Eagle cannot be shewn to have any valid claim to the title usually conferred upon it, so neither can the present species, or in fact any other of the tribe to which it belongs, assert any nobility beyond that of appearance and personal strength.

The Erne, or Sea Eagle, seems to be a compound of the characteristics of the Vultures, the Eagles, the Hawks, the predatory Gulls, and the Raven. It is a bird of imposing aspect, though less striking and handsome than the Golden Eagle, and not so compact: when excited it throws its head backwards, sets up the pointed feathers of the head and neck, and assumes many elegant and graceful attitudes. Its proper habitat is near the sea-shore, or fresh-water lakes surrounded by precipitous mountains: it is not however confined exclusively to coast localities, for it sometimes has been met with inland -in one instance as much as forty miles from the sea, and it occasionally also resorts to the sides of streams, in quest of salmon, trout, and other fish.

This species is of very frequent occurrence in many parts of the old world, and is in this country far more numerous than the Golden Eagle. It is the most abundant in the northern parts of Ireland and Scotland, and in the Orkney and Shetland Islands, but has also been repeatedly met with in England. It is most frequently seen in Scotland, north of Aberdeen and the Ord of Caithness, and but rarely south of St. Abb's Head.

In flight, the feet are drawn close up, and the neck doubled back, so that the head appears as it were to grow from the shoulders. In this attitude it beats its hunting grounds, the 




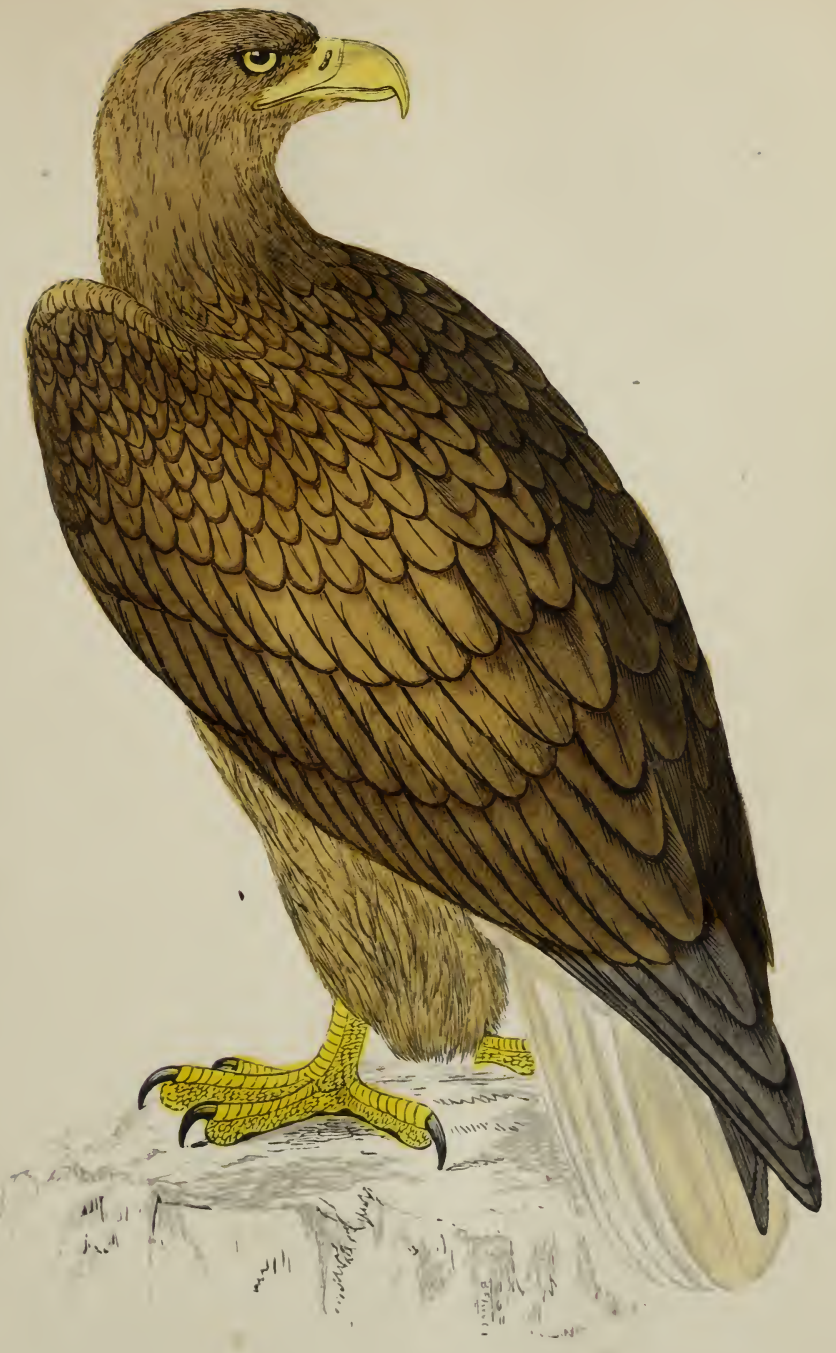


cliffs, or mountain sides, the open moors, or the shores of the ocean or lake, sailing with a gentle and hardly perceptible motion of its wings, like the Buzzard, or, if flying off in a straight line to a distance, with regular flappings like a Raven. When at rest, in its ordinary position, it sits with its wings drooped, like the Cormorants and Vultures, with the latter of which it was indeed classed by Linnæus, and it will be perceived that I have placed it next to those birds for the like and other reasons. It is not so easy on the wing as the Golden Eagle, though swift and strong in flight on occasion, and often extremely graceful. It rises with difficulty from a level surface, along which it flaps for some distance before it can do so, and may thus sometimes be brought within gun-shot, by running or riding down quickly upon it. It is described as being therefore for this reason seldom met with in such a situation at rest, but as then preferring some projection, or pointed surface, from which it can the more easily launch into the air: when it has done so and has got upon the wing, it wheels away in large circles.

Fish afford its proper and most congenial food, and these it occasionally plunges upon, after the manner of the Osprey, a little below the surface, and sometimes, an humble imitator of the predacious White-headed Eagle, is said to rob the original captor, the Osprey, of its prey, by forcing it to drop it in the air, and then seizing it before it has time to fall into its native element.

It also preys on various aquatic birds, such as gulls, puffins, and guillemots; occasionally on fawns, young roebucks, and even, though very rarely, on full-grown deer, as well as on sheep and other smaller animals, lambs, dogs, and cats, as also, on straggling domestic poultry, and in default of these, will readily feed on carrion of any kind. Herein also it seems to shew a strong affinity to the Vultures, for on meeting with such, it remains on the spot for hours and sometimes for days together, and quits it only when it no longer affords the means of satisfying the cravings of its appetite. A whole puffin was once found in the stomach of one of these birds. This species has the power of abstaining for a rery long time from food. One has been known to have lived for four or fire weeks in 'total abstinence.'

Its note, which is a domble cre---a harsh and loud scream, uttered many times in succession-and which may be heard at the distance of a mile or more, is siniller and sharper than 
that of the Golden Eagle, and is rendered by the wordskooluk, klook.

The following curious exploit of one of these birds is related by Mr. Meyer:- 'A circumstance illustrative of the great muscular strength which these birds possess, I had the pleasure it witnessing in one confined in the Zoological Gardens in the Regent's Park, in the severe winter of 1835 . I was employed in completing a sketch of the bird in question, when I observed him make many endeavours with his beak to break the ice that had frozen upon the tub of water placed in his cage. Finding all his efforts to get at the water in this manner were ineffectual, he deliberately mounted the uppermost perrh in his cage, then suddenly collecting his strength he rushed down with irresistible force, and striking the ice with his powerful claws, dashed it to atoms, throwing the water around him in all directions. After performing this feat of strength and sagacity, he quietly allayed his thirst and returned to his perch. This is no doubt the mode employed by this species in a wild state, to obtain its aquatic food, from the frozen rivers and inland seas it frequents in various parts of the continent.'

From the vast altitude at which the Erne often flies, it would seem, in common with those of its class, to be able to live in a much more rarefied atmosphere than many other birds. Occasionally a pair of these Eagles are seen fighting in the air, and their evolutions are described as being then most beautiful, as indeed they may easily be imagined to be. The 'point d'appui' is, in common parlance, to get the upper hand, so as, secure from assault, to be able to attack from a vantage ground, thus to call it though in the air, and when one of the two has succeeded in this endeavour, and is launching itself at its adversary, the latter suddenly turns on its back, and is in a moment prepared, with upraised feet and outspread talons, to receive its foe; a 'cheval de frise' not the most desirable to impinge upon.

In the Hebrides, the great damage done by, and therefore feared from Eagles of this species, makes the people interested in their destruction. Various ingenious and jet simple modes of trapping and destroying them have been devised, some requiring great patience, but all at times successful in the end. Sometimes the farmer builds a temporary hut, in which he lies hid within sight of the carcase of some animal, which he has placed at once both within shot and within view, 
and after a greater or less exercise of patience, is rewarded by the approach of the Eagle, attracted to its quarry, either by its own immediate perceptions, or from its following other birds attracted to it by the exercise of theirs. The ravens, crows, and sea-gulls have preceded him to the repast, but his arrival, harpy like, at once disperses them; the tables are turned, and they are compelled at first to withdraw to a respectful distance while he regales himself. But when he himself has become a carrion, laid low by the deadly aim of the ambuscade, it falls again to their lot to finish at leisure the feast which so lately he had disturbed; perhaps even to make a second course of his own defunct body. Mr. Macgillivray says that he has known no fewer than five of these birds destroyed in this manner by a single shepherd in the course of one winter, and he also says that in the Hebrides, where a small premium, a hen, I believe, from each house, or each farm-house in the parish, is given for every Eagle killed, as many as twenty fall victims every jear.

The same motive which prompts to the destruction of the parent birds, leads also to various 'hair-breadth 'scapes' in attempts to destroy their joung. By means of ropes, the attacking party is lowered over the edge of some awful-looking precipice, some 'imminent deadly' crag-for it is only in the most secure retreats that the Erne builds, conscious, as it would seem, of the odium under which, he lives, and the proclamation of outlawry which has been made against him in consequence -and having taken dry heather and a match with him, sets fire to the nest, and both it and its tenants are consumed before the gaze of the bereaved parents. Sometimes the eyrie can be approached and destrojed without the aid of ropes, by the experienced and adventurous climbers, who, habituated to the perils of those stupendous cliffs, make little of descents and ascents which would infallibly turn dizzy the heads of those who have only been accustomed to 'terra firma.'

This bird is the perpetual object of the buffets of the raren and the skua gull, of whom he seems to be in the greatest dread. It is indeed related that the latter does not exercise this hostility in the Hebrides, but that it does in the Shetland Islands; but I cannot understand how one individual bird, and still less how a colony of birds, can be gifted with an instinct not possessed by a colony of its own species in the same region.

In prowling for food near the ocean, the Erne generally 
flies along the side of the cliff, at an elevation of a tew hundred feet, but its powers of sight, or of smell, enable it to discover a dead quarry from a vastly greater height, and from thence it will stoop like a thunderbolt upon it. True it is, that its sense of smell does not enable it to detect the presence of a man concealed from its sight at the distance of only a few yards, but this can be no argument whatever against its having a keen scent for that which forms naturally a large proportion of its food, and especially when it is so strongly calculated to act powerfully on the organs of scent.

The Erne is never a gregarious bird; its habits perhaps forbid the exercise of the sociable qualities. Five is the largest number that have been seen in company, even when assembled to prey on a common carrion, and at other times, if as many as three are observed together, it is probably just before the breeding season, or at, and subsequent to that time: it is not until some weeks after the joung birds have forsaken the nest, that both the parents leave it altogether.

An Erne has been known to be attacked by a hawk, supposed to be, probably a Goshawk, and struck down into the sea, both birds falling together. One has been seen in the island of Hoy, sailing off with a pig in its talons, which on enquiry at the farm from whence it had been stolen, was found by the clergyman of the place, who witnessed the fact, to have been four weeks old. Another which had a hen in its talons, dropped it to make a swoop at a litter of pigs, but the sow, with maternal courage, repelled the aggressor, who consequently lost his previous prey, which escaped safely, decidedly a narrow escape, into the farm-house. Another is recorded to have. entered a turf pig-stye, in which a pig had died, and being unable to escape through the hole at the top, by which it had descended, in the way of the hungry mouse in the fable, was caught in this novel and unintentional kind of trap, and slain in due course. Others are decoyed in Sutherlandshire, and doubtless in the same manner elsewhere, into a square kind of stone box with an opening at one end, in which has been fixed a noose: the Eagle, after eating of the bait placed within it, walks lazily out of the opening, and is caught by the loop.

On one occasion, a large salmon was found dead on the shore of Moffat water, and an immense Erne lifeless also beside it, having met its fate by being hooked by its own claws to a fish too large and powerful for it to carry off-an unwilling 
example of 'the ruling passion strong in death,' and an unwonted passage in the life and death of a fish, in whose case the usual order of things in the matter of hooking was rerersed.

The following somewhat similar story is related by Bishop Stanley:- A halibut, a large flat-fish, resembling a turbot, reposing on or near the surface of the water, was perceired by an Erne, which immediately pounced down and struck his talons into the fish with all his force. Should the halibut be too strong, the Eagle, it is said, is sometimes, but rarely, drowned in the struggle. In this case, however, as more frequently happens, he overcame the fish, on which he remained as if floating on a raft, and then spreading out his wide wings, he made use of them as sails, and was driven by the wind towards the shore.'

The Erne, like the Golden Eagle, is said to have not unfrequently supplied the wants of different persons in the Hebrides, by the food it had brought to its nest in abundance, for its young. It does not, as that bird, attack those who molest its nestlings, but there are two curious accounts on record of its assailing, in an unprovoked manner, persons whom it had surprised in hazardous situations on the edges of some dangerous cliffs. Mr. Leadbeater had one of these birds which became quite tame, and eren affectionate to those about it.

It is said that the Erne is more plentiful in Britain in the winter than at any other season, which, if so, would make it appear that it partially migrated. It builds in March, and sits rery close, but is by no means so courageous as the Golden Eagle in defending its brood; one instance to the contrary is indeed on record, but the exception only prores the rule.

The nest, which is about fire feet wide, and rery flat, haring only a slight hollow in the middle, is a mass of sticks, heather, or sea-weed, as the case may be, arranged in a slorenly manner, and lined with any soft material, such as grass, wool, or feathers. It is placed on some precipice, or in the hollow of a crag or rock, overhanging the sea, or else on some inland fastness, perhaps an island in a lake, or sometimes on a rock at the edge of one. The male bird is said to take his turn at incubation with the female. The Erne is less strongly attached to its haunts than the Golden Eagle, but it seems in some degree fond of them, and not unfrequently returns to the same breeding place for several years in succession.

The eggs, which, by a merciful provision, are few in number, as are those of the other Eagles, one, or at the most, two, 
(though some say three, and that the third is always an addled one,) are white, yellowish white, or yellowish brown, and some are wholly cuvered with light red spots, while others have only the large end dotted over. One of these birds has been known to lay an egg after having been in confinement for more than twenty years. The young are hatched about the beginning of June, and fully fledged about the middle of August.

The Erne varies much both in size and in colour, which latter becomes more cinereous as the bird advances in age, and this was the cause of the one species, in the different stages of its plumage, having been imagined to be two distinct ones. One has been killed in Sutherlandshire, entirely of a silvery white hue, without any admixture of brown, and another of the like appearance was seen at the same time in company with it. A very curious variety in the Zoological Society's Collection is thus described by Meyer, in his 'Illustrations of British Birds,' 'No painting can fitly represent the delicate and beautiful colour of this bird. When its feathers are ruffled, as may be frequently observed, at the pleasure of the creature, a delicate azure blue tint is seen to pervade the basal part of the feathers, which, appearing through the whole transparent texture, imparts to its plumage the singular tint it displays. It is observable that the beak of this individual is rather less in depth at the base than is usual in this species, and the iris yellowish white.'

It is also to be remarked that the differences in size between the male and the female, is not nearly so great as is usual in the case of the other Eagles, and so conspicuously so in the species next described, and that they are also very similar in general appearance. The following is the description of the adult bird:- Weight, about eight or nine pounds; length, about three feet. Bill, dark straw-colour (at two years old, increasing in intensity of colour as the bird grows older,) and with a bluish skin, slightly bristled over, extending from its base to the eyes; cere, yellow; iris, bright yellow, and remarkably beautiful and expressive. The feathers underncath the lower bill are bristly; crown of the head and neck, pale greyish brown, the feathers being hackles; breast and back, dark brown. The wings, when closed, reach the end of the tail, the fourth and fifth quill feathers being the longest: their expanse is about six feet and a half; secondaries, brown, partly tinged with grey. The tail, which is rather short and rounded, and consists of twelve broad feathers, has a small 
portion of its base deep brown, and the rest white, that is, when fully adult, which some say is after the third moult, and others not until the bird is five years old. The legs, which are feathered a little below the knee, are straw-coloured, and have a series of scales in front. The middle toe has eight large scales, tile outer one tive, and the inner and hinder ones four each. Another description assigns to the first and second toes three; to the third twelve; and to the fourth, six. Another describes the middle toe as having sixteen, and the side and hind toes, six each; and, again, another gives thirteen to the middle one; so that it seems to me pretty certain, that no distinctive character is to be derived from their number: age may very possibly have something to do with it. The claws are black, the middle one being groored on the under side.

The young birds, when first hatched, are covered with down of a whitish appearance: when fully fledged, the bill is deep brown tinged with blue; the cere, greenish yellow; iris, dark brown; head, deep brown; chin, dingy white; nape, white tipped with brown; breast, dull white spotted with brown; back, light brown; primaries, blackish brown; lower tail coverts, dull white, tipped with deep brown; tail, greyish at the upper end, and the rest deep brown; feet, yellow; claws, blackish brown. When further adranced in plumage, the bill is bluish black, paler towards the base; cere, yellowish; iris, chesnut brown; head, crown, and neck, dark brown, the roots of the feathers white, and the tips paler than the rest. The breast is variegated with different shades of reddish brown, a few white feathers being interspersed. The wings expand to the width of about seven feet. The tail is brown of different shades, darkest towards the end; the legs and toes, Jellow; and the claws, bluish black, tinged with brown. 


\section{GOLDEN EAGLE.}

Aquila chrysaëtos,
Fulco
Selby. JenyNS. Montagu.

\section{Aquila-An Eagle, possibly from Aquilus-Dark-sunburnt. Chrysaëtos-Chrusos-Gold. Aietos-An Eagle.}

THE Golden Eagle is so called from the golden red feathers on the head and nape of the neck. It seems to have established a prescriptive right, though on what exclusively sufficient grounds it might be difficult to say, to the proud appellation of the king of birds, as the Tiger, in the corresponding predatory class among quadrupeds, has obtained that of 'Royal.' The epithet would however be more appropriately conferred upon the Lion, to whom many noble qualities, to be looked for in vain either in the Tiger or the Eagle, have in all ages been attributed, though whether even in his case justly, is more than doubtful.

The appearance, however, of this bird, is certainly very noble and majestic, though not more so, perhaps, than that of many others of its family, and if his aspect is fine in the only state in which we can have an opportunity of observing him closely, how much more striking would it appear, if we could, ourselves unseen, behold him in his state of nature, standing on the outermost projection of some overhanging precipice of the mountain, and looking out, with his large and piercingly lustrous eye into the far distance below, for some quarry on which to stoop for his own food, or that of his young ones in the nest.

The Golden Eagle seldom strays far from its native haunts, and is, probably from the nature of its habits, not numerous in any particular spot; but those habits make it but too much so where it is found, which is, as may at once be imagined, in the most mountainous and rocky districts-the natural haunts of these 'feræ naturæ' which are its food-or in large 




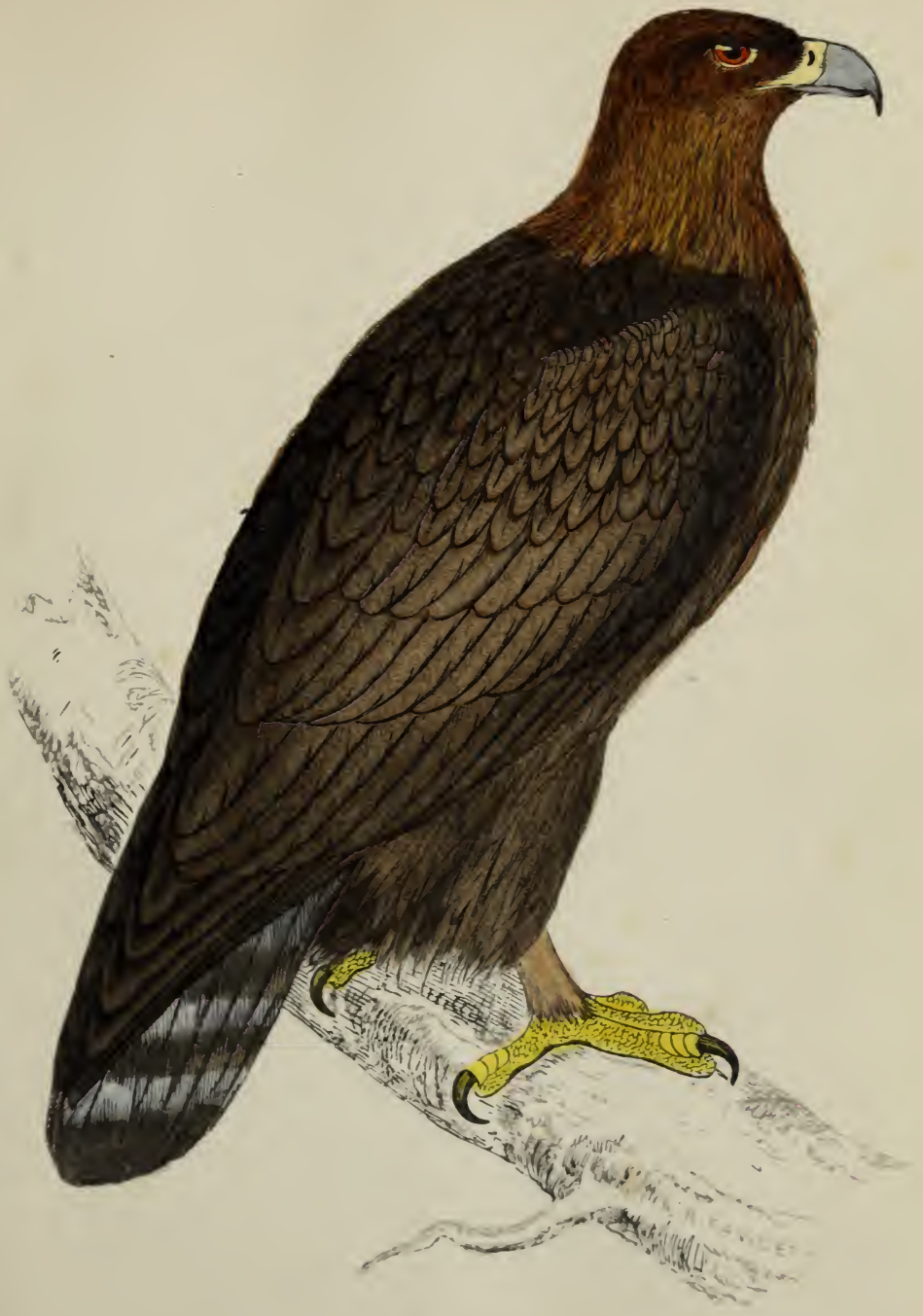



forests on the plains. It is met with in India, and various parts of Asia, as well as in erery part of the continent of Europe, and also in North America, in greater or less numbers. It was formerly far from uncommon in England, and in still more ancient times, in all probability, was much more frequent. In Yorkshire, one has been recorded by Arthur Strickland, Esq. as having occurred in the East Riding, and a second was killed by Admiral Mitford's gamekeeper. Another was shot in 1847, at Littlecott, the seat of Mr. Popham, near Hungerford, in Berkshire: it had glutted itself on a dead deer, and was unable to fly away on the approach of the keeper, who fired six times before he killed it. Another was captured in Cheshire, in the jear 1845, at Somerford Park, the seat of Sir Charles Peter Shakerley, Bart., and another, in the same county, a few years previously, near Eaton Hall, the seat of the Marquis of Westminster.

It has been known to breed regularly, even up to a comparatively recent date, in Cumberland and Westmorland, and also formerly in Derbyshire; in which county one was captured alive, near Glossop, in some severe weather, in the jear 1720; another, about the sear 1770, was shot at Hardwick Park, a seat of His Grace the Duke of Devonshire, one of the foundations of the celebrated 'Bess of Hardwick', another about the year 1820, near Cromford, and another was seen at Matlock in 1843, but, though frequently shot at, it was not procured. They are still not very unfrequently to be seen in the highlands of Perthshire and Sutherlandshire, chiefly in the north and north-west parts, and on the mountains of other counties in Scotland, such as Ben Lomond, and Ben Neris, and still more frequently on the mountains of Ireland. Thirteen or fourteen were killed between the years 1828 and 1S32, in the county of Donegal, and some hare been in the habit of breeding in the Island of Achil, as well as near Killarner, and at Rosheen, near Dunfanaghy: others have been mct with near Belfast, Tralee, Monastereran, the mountain of Croagh Patrick, and in many other parts of that island, as also on the Scottish border, and in the highlands of Wales, as well as, though but rarely, in Shetland.

The flight of the Golden Eagle, when not pursuing its prey, is at first slow and heavy like that of the Heron, and when sailing in the air, much resembles that of the Common Buzzard. It often ascends to a vast height when looking out for food, and on perceiving its quarry, descends upon it like a flash of 
lightning, though sometimes in doing so, it will make several spiral turns at intervals, as if to break the extreme violence of the shock of its fall. If it does not then at once discern its victim, which has, perhaps, attempted to hide itself, it peers about with its outstretched neck in every direction, when, if it again eatch a glimpse of it, as it is almost sure to do, it is down upon it directly with extended legs, and scarce seeming to touch it, bears it off in triumph. It usually thus secures the animal, seizing it before it can even attempt to escape, or perhaps paralyzed through fear, but occasionally, as in the instances hereafter stated, follows in pursuit. One is mentioned which was seen hovering above a hare, which it frightened from bush to bush, until at last it forced it to leave its cover, and attempt escape, when it was almost immediately overtaken and pounced upon.

It is a curious fact that two Eagles will sometimes course a hare together-one flying directly over it, and the other following it near the ground; and one has been known to stoop at a hare pursued by the hounds, and to carry it off, a hundred yards before them-a singular realization of the fable of Tantalus.

The female is noisy and clamorous at the approach of spring, and also before wet or stormy weat?.'.er.

The food of the Eagle consists principally of the smaller animals, such as sheep, lambs, fawns, rabbits, and rats, as also of birds, such as blackcock, grouse, and sea-gulls. It does not hesitate, however, on occasion, to attack larger game, but assails with characteristic resoluteness even roebucks and other deer. It is said to fix itself on the head of the victim it has aimed at, and to flap with its wings in the animal's eyes, until in distraction it is driven over some precipice, or into some morass, where it then becomes a secure and easy prey. One was seen flying in one of the Orkney Islands with a pig in its talons, which it dropped alive when fired at. Another, in Ireland, alighted and carried off a lamb, with which it flew in a straight direction towards its haunt in the Mourne mountains. There arrived, it was seen to soar upwards, probably towards its nest, but dropped the lamb at the edge of a wood, and it was recovered unhurt-the distance flown was reckoned to be more than two miles with this burden to support. There are at least three authenticated instances of their having carried off children in this country-one of these in one of the Orkney Islands, and another in the Isle of Skye, 
but both, providentially, were rescued. Doubtless there have been often such cases, some not recorded, having occurred in remote districts, and others possibly not even known of.

The numbers of animals and birds destroyed by Eagles must be very great: the remains of three hundred ducks and forty hares were found in the eyrie of one in Germany; and it is on record, that a peasant in the county of Kerry, and another in the county of Antrim, supported their families for a considerable time, by means of the animals brought by parent Eagles to their nests.

The Golden Eagle never feeds on carrion, unless forced by hunger, when unable to meet with prey to kill for itself.

The age attained by the Eagle is unquestionably rery great: one that died at Vienna, is reported to have lired, even in confinement, one hundred and four years. It rarely drinks, but is fond of washing itself. It is said to keep fat to the last, as if the faculties of its natural instinct did not deteriorate as its age increased, but were sufficient, with the benefit of its experience, to supply the place of its pristine strength. One which I have lately seen the body of, previous to the skin being stuffed by Mr. Graham, of Iork, was remarkable for the quantity of fat upon it. It appeared to be a very old bird, and the talons were of an extraordinary length. It had just been sent from Assjnt, in Sutherlandshire, by W. M. E. S. Milner, Esq, M.P. The Golden Eagle is easily kept in confinement, and in some cases becomes to a certain extent tamed, from being constantly familiarized with the sight of its keeper. It is, nevertheless, on the whole extremely intractable; one howerer is related to have been tamed at Fortwilliam, near Belfast, by Richard Langtry, Esq., which would come at its master's call, and another to have been trained by Captain Green, of Buckden, in Huntingdonshire, to take hares and rabbits. Another, as I presume it to have been, is mentioned by the late Bishop Stanley, in his 'Familiar History of British Birds,' as having been so thoroughly tamed as to have been left at perfect liberty, neither chained or pinioned: of this freedom it would often avail itself, and after having been absent for two or three weeks would again return. It never attacked children, but on one occasion, it is supposed from its master having neglected to bring it its usual supply of food, it assailed him with some violence. Young pigs it would occasionally make a meal of. After having been safely kept for ten or twelve years, it was unfortunately, in the end killed 
by a savage mastiff dog. The battle was not witnessed, but it must have been a long and well-fought one. The Eagle was slain on the spot: he did not, however, die unrerenged, for his antagonist very shortly afterwards expired of his wounds. Again, instances have occurred where Eagles which have carried off such animals as weasels, stoats, etc., have been attacked with relentless bite by these fell blood-suckers, and have at last fallen to the ground lifeless in consequence. There is a similar story told of the encounter of one in the air with a cat, which it had carried off. He was fairly brought to the ground, the talons of the cat proving more effective than his own, and both were captured together.

When the Golden Eagle has pounced upon its victim, it kills it, if small, by a stroke with its talons, behind the head, and another at the region of the heart. It seems not to use the bill for slaughter, but only for tearing up its prey when killed. It generally, in spite of its care and skill in skinning or plucking, swallows part of the fur or feathers, or small bones, or parts of bones of the animal or bird it has seized, and these it afterwards disgorges from its mouth in large pellets.

In India, and other countries, there are numerous accounts of young children having been carried off by Eagles, but, as it must now be impossible to say with any certainty what species they were of, though possibly in some, or even. in many cases, they may have been of the one I am treating of, yet as in others, beyond all doubt, they have been birds of the Vulture kind, or of other species of Eagles, I omit them from this account, recording those instances alone in which the bird at present before us has been the robber.

By the Ancients the Eagle was denominated the Bird of Jove, and alone deemed worthy of bearing his thunder. The Highland Chieftain at the present day exhibits the Eagle's plume as the designation of his nobility, and as uncivilized nations have also always associated birds of this tribe with the idea of courage, quickness, and dignity, their warriors too in like manner pride themselves on the badge which the feathers of the Eagle furnish them with, either as an emblematic trophy of past, or a pledge of future bravery and daring. They prize it so highly, that they will often exchange a valuable horse for the tail feathers of a single Eagle. They also adorn with them their arrows, and the calumet or pipe of peace. The feathers of the Eagle are used in our own country for making certain salmon flies. 
The nest, which is very large, and has no lining, according to some authors, but is stated by others to be lined a little with grass or wool, and where these cannot be procured, or not in sufficient plenty, with small sticks, twigs, rushes, seaweed, or heather, is generally built on high and inaccessible rocks and precipices, or the stump of some tree projecting from them, or the lofty trees of the forest. It is always, where possible, rebuilt of the same materials-the accustomed eyrie being made use of for many successive years, or, most likely, from the most farourable locality as to food and security combined having been chosen, for many generations, if its owners are not driven from it by their only superior enemy; man. This latter assertion must however be understood with certain exceptions, as in the instances recorded abore.

The eggs, generally two in number, but in some cases three, are purely white, sometimes greyish white, and sometimes completely mottled or marbled over with light russet brown.

The length of the male bird is about three feet or three and a half, and the expanse of the wings eight feet to eight and a half; the female, as is the case with the rest of the Eagle tribe, is larger, measuring about three feet and a half in length, and nine feet in width: one was killed at Warkworth, in Northumberland, which measured the unusual size of eleren feet and a quarter from tip to tip.

In the adult, which weighs from nine to sixteen or eighteen pounds, the bill, (with which it sometimes makes a snapping noise,) is horn-colour, or deep blue; the cere, pure yellow; the iris, which is dark in the roung bird, grows lighter as the bird advances in age, and ends in being of a clear orange brown; the crown of the head and the nape, the feathers of which are hackles, are sometimes bright golden red, but generally of a grey or hoary colour; all the rest of the body is obscure dark brown, more nearly approaching to black as the bird grows older; but when in extreme age, to which the Eagle is known to reach, its plumage becomes rery light coloured, thin and worn, so much so, as to make it appear that the bird had ceased to moult. The tail, which is a little longer than the wings, and of a square shape, with the exception of the two middle feathers, which exceed the others in length, and are rather pointed, is deep brown, paler on the base, barred with dark brown, with one broad bar terminating it. The legs are feathered down to the toes, and the plumage on them is of a clearer brown than that of the 
rest of the body. The feet are at first greyish yellow, which merges into pure yellow; the expansion of the foot seven inches, including the claws; the middle toe measures three inches and a half in length, and there are on it three or four large scales; and on the outer, inner, and hinder toes, three, on the last joint of each. The claws are black, much hooked, and very formidable weapons of attack or defence, the middle one being three inches in length. During the first year there is a well-defined white bar on the upper and larger half of the tail, but after this period, it is at each moult encroached upon by the brown colour of the lower half, until the roots alone of the feathers remain white. 



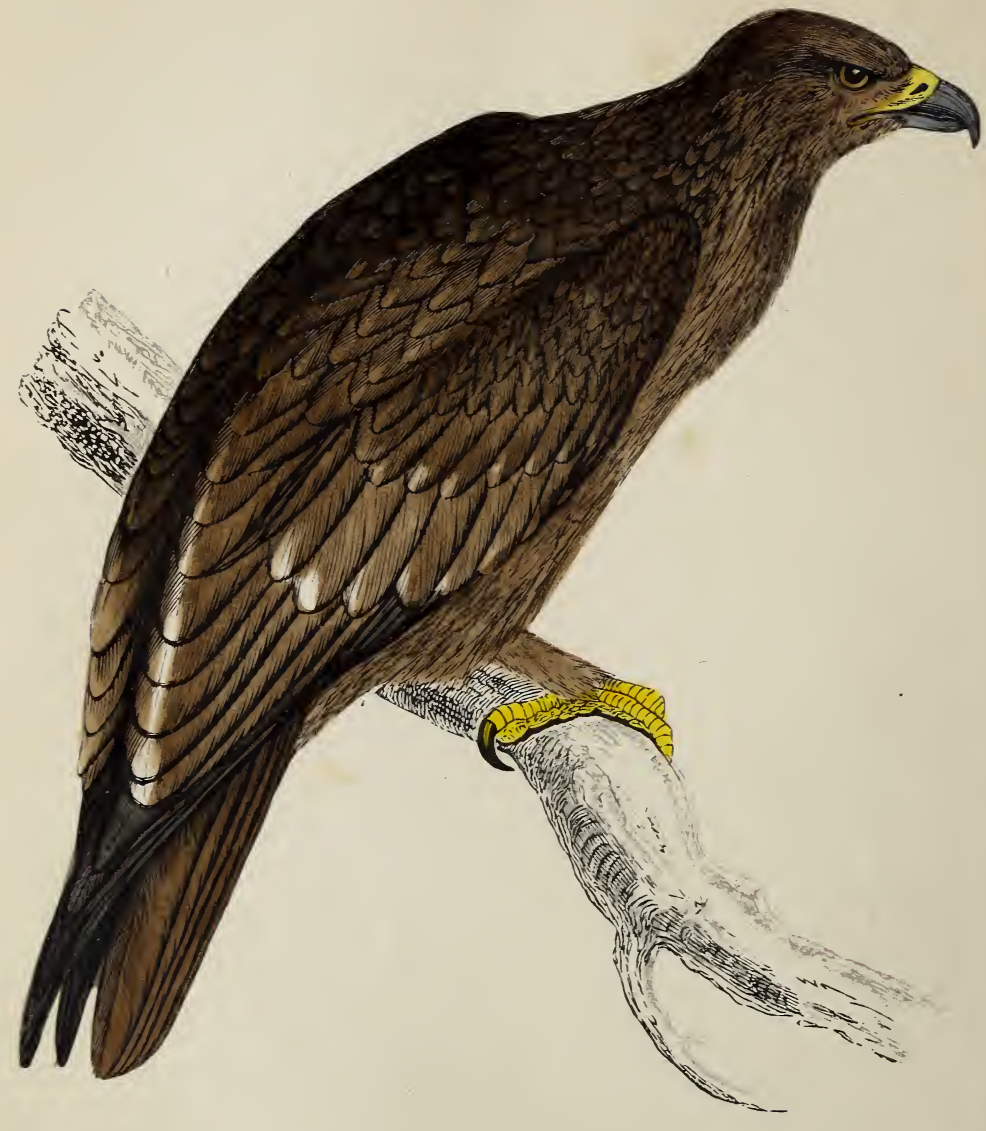

SPOTTED EAGLE. 




\section{SPOTTED EAGLE.}

\author{
Aquila navia, \\ " melanaëtos, \\ Falco navius,
}

Aquila-An Eagle.
GOULD.

SAvignt.

Temminck.

ThE Spotted Eagle is an inhabitant of most parts of Europe, having been observed in France, Belgium, Italy, where among the Apennines it is very common; Germany, Sicily, and Russia; also in the northern districts of Africa, and in Asia, in India, in Siberia, the Bengal territory, Nepal, and near Calcutta. As in the case of the Griffon Vulture, only one example of this addition to our native Fauna, has, as yet, been obtained for preservation. It is singular, also, that the one in question occurred in the same neighbourhood as the other alluded to, namely, in the county of Cork. It was shot in the month of January, in the year 1845, in the act of derouring a rabbit, in a fallow field, on the estate of the Earl of Shannon, near Castle Martyr. Another individual in lighter plumage, no doubt its mate, was killed at the same place, about the same time, but unfortunately was not preserved: both had been observed for the two preceding months sweeping over the low grounds in the neighbourhood. It has been thought that very probably this species has been confounded in Ireland with the Golden Eagle, and that it may be indigenous there, both the specimens above mentioned having been in immature plumage. It has by some been asserted, that it is a common species in that country, and known by the name of the Silver Eagle. One is said to have been kept in captivity at Cahirciveen, and a pair are related to have bred regularly on the island of Valentia.

Cuvier says, that it was formerly employed in falconry, but that being deficient in courage, it was only employed for taking the smaller kinds of game. It seems to form one of the connecting links between the Eagles and the Buzzards, as I hare in a previous article stated that the Sea Eagle seems, in like 
manner, to do between the Eagles and the Vultures. In fact, though called an Eagle, and classed with those birds, it would seem to be possessed of more of the characteristics of the Buzzards.

The Spotted Eagle flies low in hawking after its prey. It feeds on rabbits, rats, and other small animals and reptiles, as also on birds, particularly on ducks, as well as on some of the larger species of insects.

It builds on high trees, and lays two whitish eggs, slightly streaked with red. Like the Osprey, it seems to suffer smaller birds to build without molestation, in the immediate vicinity of its nest, or even in the outer parts of the nest itself.

This species is about two thirds the size of the Golden Eagle in linear dimensions. It measures about two feet three and a half or four inches in length. In the adult state, the general colour of the plumage is brown, varying in depth of tint according to the age of the bird. The bill is dark bluish horn-colour; cere, yellow. The head, both above and below, of a light brown; neck, dark reddish brown, the feathers, as in the Golden Eagle, being hackles; back, the same colour. The breast is rather lighter than the back. The wings, which when closed reach to the end of the tail, have the fourth and fifth quill feathers nearly of an equal length, but the fifth rather the longer, as it is also the longest in the wing; the primaries are almost black-all the feathers white at the base. The tail coverts are bright brown; tail, dusky black, barred with a paler colour, and the end of a reddish hue. The feet are yellow; claws, black.

The young bird in its first year has the bill of a dark bluish horn-colour, darker towards the tip than at the base; cere, yellow; iris, hazel; the head, neck, and back, dark chocolate brown; breast, the same; the margins of the greater and lesser coverts, as also the tertials, tipped in a well-defined elliptical form with yellowish white or white. The tail is dark chocolate brown. The legs are feathered down to the feet, and these feathers are variegated with lighter shades of brown; toes, yellow, reticulated for part of their length, but ending with four large broad scales; claws, nearly black. In its second year, the colour of the whole plumage becomes more uniformly of a general dark reddish brown. 



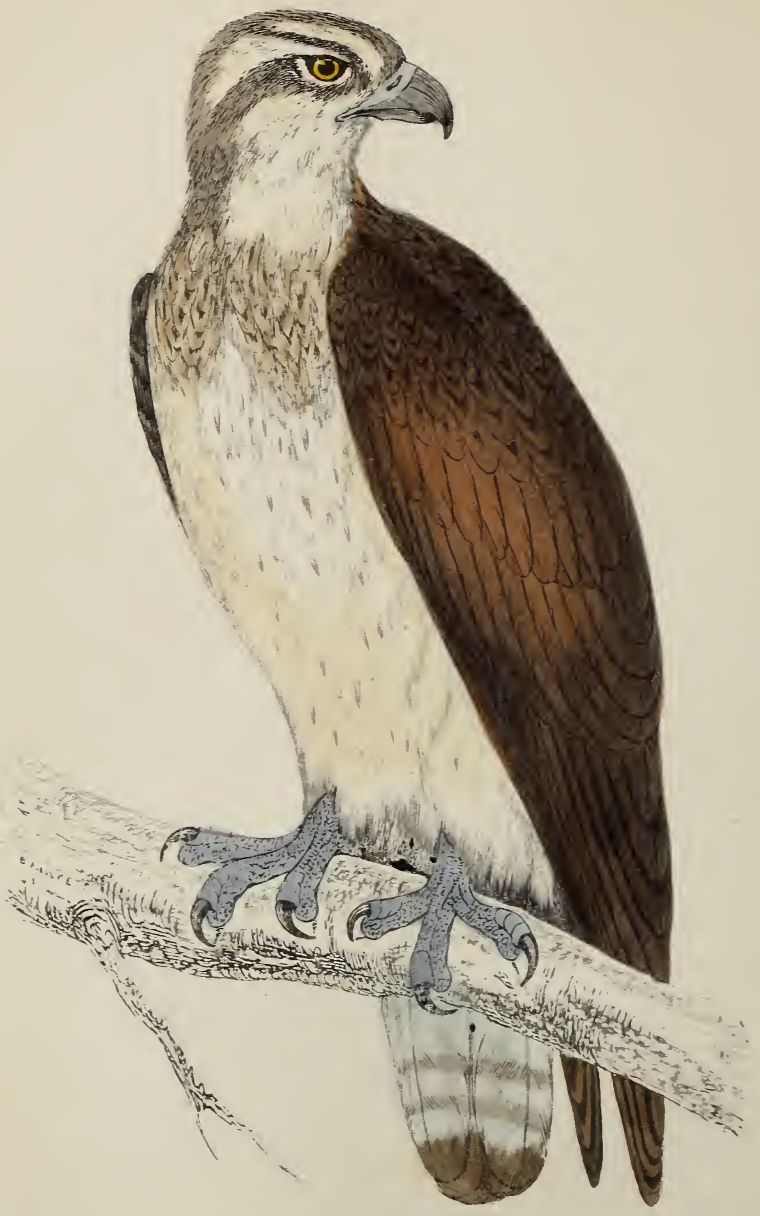





\section{OSPREY。}

Pandion haliaëtus,
Falco "6
Balbusardus haliaëtus,
Aquila :6
SAVIGNT.

BEWICK.

Fleming.

JENYNS.

Pandion-The name of a Greek hero, changed into a bird of prey.

Haliuëtus. (H)als-The sea. Aietos-An Eagle.

IT is not every one who has had the fortune-the good fortune-to visit those scenes, where, in this country at least, the Osprey is almost exclusively to be met with. In these, which may in truth be called the times of perpetual motion, there is indeed hardly a nook, or mountain pass, which is not yearly visited by some one or more travellers. Where shall the most secure dweller among the rocks be now free from the intrusion of, in ornithological language, at least 'occasional visitants?' Still the case is not exactly one to which applies the logical term of 'universal affirmative.' Though every spot may be visited, it is not every one who visits it. How many of those who shall read the following description of the Osprey, have taken the 'grand tour' of Sutherlandshire?

In that desolate and romantic region, though even there at wide intervals, and 'far between,' and in a very few other localities, the Fishing Hawk may yet be seen in all the wild freedom of his nature. There it breeds in the fancied continuance of that safety, which has for so many ages been real. You may see, even in the year eighteen hundred and fifty, an occasional eyrie on the top of some rocky islet in the middle of the mountain lake.

This species is very widely distributed over a large portion of the globe, being met with, in greater or less abundance, in Europe, Africa, and America, sometimes in very considerable numbers, and doubtless in Asia also. In America it seems to be most particularly numerous, a whole colony tenanting the same building place. It is also met with in Russia, Siberia, Kamtschatka, Scandinavia, France, Spain, and Germany, Swit- 
zerland, and Holland, in Egypt, Tripoli, Nigritia, the Cape of Good Hope, Japan, and New Holland, and has been hitherto far from unfrequent in England, most numerous at either extremity of the country, namely, in Sutherlandshire and Devonshire. Specimens have been killed in Berkshire, at Donnington and at Pangbourne, the latter one in the year 1810, in the month of January. Three in Oxfordshire, one of them at Nuneham Park, the seat of George Harcourt, Esq.: and one at Udimore, in Sussex, by the keeper of F. Langford, Esq. in November, 1848. Others in Shropshire, Somersetshire, and Hertfordshire. One is mentioned by the Rev. Gilbert White, in his 'Natural History of Selborne,' as having been killed at Frinsham Pond, in Hampshire.

It has been frequently observed at Killarney, in Ireland, and no doubt occurs in many other parts of the sister island.

It has been in the habit of building regularly in many parts of Scotland, on Loch Awe, Loch Lomond, Loch Assynt, Scowrie, Loch Maddie, near Durness, and Rhiconnich, in short, on many, or most of the Highland Lochs; also at Killchurn Castle, and is said to breed in the Orkney Islands, Killarney, and near the Lizard Point. It has frequently been seen on and near Dartmoor, in Devonshire: two were procured in that locality in the month of May, in the year 1831, at Estorer; one in the same year at another place in the same county, and two on the Avon. Three or four have been met with in the county of Durham-one seen near Hartlepool-others in Sussex -one in Hampshire, in Christchurch bay, where, Mr. Yarrell says, this bird is called the Mullet Hawk, a name far from unlikely to be appropriate, for these fish are remarkably fond of basking near the surface of the water, so that they may easily be killed with stones. In Yorkshire numerous specimens have been at various times procured; so many that I need not here more particulary enumerate them. There is no record of the Osprey having been seen in the Hebrides.

The Osprey being so strictly a piscivorous bird, is only met with in the immediate neighbourhood of water; but salt and fresh water fish are equally acceptable to it-bays and the borders of the sea, as well as the most inland lakes, rivers, and preserves, are its favourite resort: when young, it may even, it is stated, be trained to catch fish.

Temminck and Wilson state that the Osprey migrates in the winter. In Scotland, it is said to arrive in Sutherlandshire in the spring, but on the other hand the specimens which 
have occurred on the Tweed, are recorded as having appeared there in the autumn.

The Osprey is in some degree, or rather in some situations, a gregarious bird. As many as three hundred pairs have been known to build together in America, which, as before remarked, seems to be by far its most abundant habitat. It is a very frequent circumstance for several pairs thus to congregate; the similarity of their pursuit by no means seeming to interfere with that harmony which should ever prevail among members of the same family. They sometimes unite in a general attack on their common enemy, the White-headed Eagle, and, union being strength, succeed in driving him from their fishing-grounds, of which they then maintain the peaceable possession.

It would appear from the mention of the Osprey, by Izaak Walton, under the name of Bald Buzzard, that it was formerly used in falconry.

The flight of the Osprey, though generally slow and heary like that of the Buzzard, and performed with a scarcely perceptible motion of the wings, is strikingly easy and graceful. It rises spirally at pleasure to a great height, darts down perhaps at times, and then again sails steadily on. When looking out for prey, on perceiving a fish which it can strike, it hovers in the air for a few moments, like the Kestrel, with a continual motion of its wings and tail. Its stoop, which follows, though sometimes suspended midway, most likely from perceiving that the fish had escaped, or to 'make assurance doubly sure,' is astonishingly rapid. The similar action of the Sea Swallow may serre to give some faint idea of it.

If the fish it has pounced on be at some distance below the surface, the Osprey is completely submerged for an instant, and a circle of foam marks the spot where it has descended: on rising again with its capture, it first, after mounting a few yards in the air, shakes its plumage, which, though formed by nature extremely compact for the purpose of resisting the wet as much as possible, must imbibe some degree of moisture, which it thus dislodges. It then immediately flies off to its nest, if it be the breeding-season, or to some tree if it is not, and in that situation makes its meal. When this is ended, it usually, though not always, again takes wing and soars away to a great height, or else prowls anew over the waters - unlike the other Hawks, which, for the most part, remain in an apathetic state, the result apparently of satisfied hunger: 
thus continues the routine of its daily life. Sometimes it is said to devour its food in the air, but I cannot think this. The audacious White-headed Eagle often robs the too patient Osprey of its hardly-toiled-for prey before it has had time to devour it itself, forcing it to drop it in the air, and catching it as it falls.

The sole food of the Osprey is fish, and from its manner of taking it by suddenly darting or falling on it, it has been called by the Italians, 'Aquila plumbina,' or the Leaden Eagle. It is however said by Montagu, that it will occasionally take other prey-that one has been seen to strike a young wild duck, and having lost its hold of it, to seize it again a second time before it reached the water. I must, however, express the strongest doubt of this having been the case. If the circumstance as described to him really occurred at all, I can hardly think but that some other species must have been mistaken for the one before us, particularly from the latter fact mentioned, for Wilson, whose opportunites of observing this bird were so abundant, says expressly, that not only does it feed exclusively on fish, but that it never attempts to seize a second time one which it may have dropped. It usually takes its prey below the surface of the water, and never catches it when leaping out, even when in the case of the flying fish it has ample opportunities of doing so, though when that persecuted creature is again submerged, it will follow it into its more legitimate element, and take it there without scruple. It never preys on any of the inferior land animals, which it might so easily capture were it thus disposed. Even when the lakes, which supply its usual food, are frozen over, and when it is difficult to imagine how it can supply its wants without resorting to other, even if uncongenial, food, it does not do so.

The Osprey seldom alights on the ground, and when it does so, its movements are awkward and ungainly. It is not in its element but when in the air; occasionally however it remains for several hours together in a sluggish state of repose.

It builds at very different times, in different places-in January, February, March, April, and the beginning of May: the latter month appears in this country to be the period of its nidification. It repairs the original nest, seeming like many other species, to have a predilection from year to year, for the same building place. The saline materials of which it is composed, and perhaps also the oil from the fish brought to it, 
have the effect, in a few jears, of destroying the tree in which it has been placed. The male partially assists the female in the business of incubation, and at other times keeps near her and provides her with food-she sits accordingly very close Both birds, when the young are hatched, share the task of feeding them with fish, and have even been seen to supply them when they have left the nest and have been on the wing themselves; they both also courageously defend them against all aggressors, both human and others. They only rear one brood in the year. If one of the parents happen to be killed, the other is almost sure to return, ere long, with a fresh mate: where procured, as in other similar cases, is indeed a mystery.

The nest of the Osprey is an immense pile of twigs, small and large sticks and branches, some of them an inch and a half in diameter-the whole forming sometimes a mass easily discernible at the distance of half a mile or more, and in quantity enough to fill a cart. How it is that it is not blown down, or blown to pieces by a gale of wind, is a question which has yet to be explained. It occasionally is heaped up to the height of four or fire feet, or even eight, and is from two to three feet in breadth, interlaced and compacted with sea-weed, stalks of corn, grass, or turf; the whole, in consequence of annual repairs and additions, which even in human dwellings often make a house so much larger than it was originally intended to be, not to say unsightly, becoming by degrees of the character described above. It is built either on a tree, at a height of from six, seven, or eight to fifteen feet, and from that to fifty feet from the ground; on a forsaken building, or the ruins of some ancient fortress, erected on the edge of a Highland Loch, the chimney, if the remains of one are in existence, being generally preferred, or on the summit of some insular crag; in fact, it accomodates itself easily to any suitable and favourable situation. Bewick, erroneously following Willughby, (and Mudie him,) says that the Osprey builds its nest 'on the ground among reeds'-it very rarely indeed does so. It is a curious fact that smaller birds frequently build their nests in the outside of those of the Osprey, without molestation on the one hand, or fear on the other. Larger birds also build theirs in the immediate vicinity, without any disturbance on the part of either.

The eggs, which are sometimes only two in number, but occasionally three, and in some instances, but very rarely, as 
many as four, are described by several writers, apparently following Willughby, to be of an elliptical form. They are laid in May, and are about the size of those of a hen, and are generally similar to each other in colour, but occasionally vary considerably in size and shape: the ground colour is white, or dingy jellowish, or brownish white, much mottled over, particularly at the base, in an irregular manner, with jellowish brown or rust-colour, with some specks of light brownish grey. The larger spots are sometimes of a very fine rich red brown.

Weight of the male, between four and five pounds; length, about one foot ten or eleven inches; bill, black, bluish black, or brownish black, probably according to age, and blue or horn-colour at the base; cere, light greyish blue; iris, yellow. The rudiment of a crest is formed by the feathers of the nape, which are lanceolate; head, white in the fully adult bird; until then, the feathers are brown, margined with white; crown, whitish or yellowish white, streaked with dark brown longitudinal marks; neck, white, with a brown mark from the bill down each side. The nape, whitish, streaked with dark brown; chin, white, with sometimes a few dusky streaks; throat, white or brownish white, streaked with dark or dusky brown; breast, generally white, mottled about the upper part with a few rather light brown feathers, forming an irregular band, and also more or less sprinkled with yellowish or brown markings-the margins of the feathers being paler than the rest. Selby says that the brown admixture is indicative of a young bird, the adults generally, if not always, having that part of an immaculate white, and there can I think be no doubt but that it is so. The whole plumage, especially on the under side, is close set, as is the case with water birds, their frequent submersions requiring such a defence.

The back, dark brown-in some individuals the feathers being margined with a paler shade; wings, long, and of wide expanse, measuring five feet three or four inches across. When closed, they extend a little beyond the end of the tail-not quite two inches; the first three quills are deeply notched on the inner side near the end; primaries, dark brown, black, or nearly black at the ends. The tertiaries assume the form of quills; larger and lesser under wing coverts, white, barred with umber brown; tail, short and square, waved with a darker and a lighter shade of brown above, and beneath barred with greyish brown on a white ground-the two middle feathers darker than the others. The legs reticulated, and pale blue. 
They are very short and thick, being only two inches and a quarter long, and two inches in circumference-great strength being required for its peculiar habits. They are feathered in front about one fourth down, the feathers being short and close. The toes, pale greyish blue, and partially reticulated, with a few broad scales near the end, and furnished beneath, particularly the outer one, with some short sharp spines, or conical scales, for the evident purpose of holding fast a prey so slippery as that which the bird feeds on. The outer toe is longer than the inner one, the contrary being the case with others of its congeners, and adapted for a more than ordinary turning backwards, the better to grasp and hold a fish. The hind toe has four scales, the others only three. The claws, black, and nearly alike in length: those of the first and fourth toes being larger than those of the others.

The female is considerably larger than the male, but the colour of both is much alike. There is, however, in her a greater prevalence of brown over the white, and it is of a deeper shade, approaching on the lower part of the breast to brownish red. Weight, sometimes upwards of five pounds; length, two feet to two feet and an inch; expanse of thi wings, about five feet and a half.

The young birds are much variegated in their plumage, which becomes of a more uniform hue as they adrance in age- the grey and the brown giving, way by degrees to white.

Variations of plumage occur in the Osprey, even in its fully adult state; the white being more or less clear, and the brown more or less prevalent: the legs also vary from light greyish blue to a very pale blue, with a tinge of yellow. 


\section{BUZZARD.}

Buteo vulgaris,

Falco luteo,
Fleming.

Pennant.

Buteo-...........?

Vuigaris-Common.

Dr. JoHrson assigns as the meaning of the word Buzzard, 'a degenerate or mean species of Hawk,' but being by no means one of the admirers of the author of the Dictionary, I shall take leave to differ as much from the present as from another well-known definition of his touching the 'gentle art,' of which for many jears I have been a professor.

The Buzzard is plentifully distributed over nearly the whole of the continent of Europe, and is also found in North America, and in the more northern parts of Africa. It inhabits Spain and Italy, Denmark, Sweden, Norway, and Russia, Holland and France, but does not appear to be known in the Orkney or Shetland Islands. In England, Scotland, Wales, and Ireland, it is sufficiently abundant, affecting both the wildest and the most cultivated districts, but in both taking a more than ordinary care to choose such situations as will either exempt it from the intrusion, or enable it to have timely notice of the approach of an enemy. Still, with all its precautions, and with every aid that its own instinct and the most retired or the most rugged localities can afford, it, like too many others of our native birds, is gradually becoming more rare. The advancement of agriculture upon grounds heretofore wild and uncultivated, the natural consequence of an increase of population within a fixed circumference, and other causes, contributing to this fact, which at all events a naturalist must lament.

The Buzzard is found in a variety of situations, such as rocky cliffs, chases, parks where timber abounds, or in 'ci devant' forests. It remains in England throughout the year, but, nevertheless, is partially migratory.

I am much indebted to my liberal-minded friend, Arthur Strickland, Esq., of Bridlington-Quay, for the following striking 




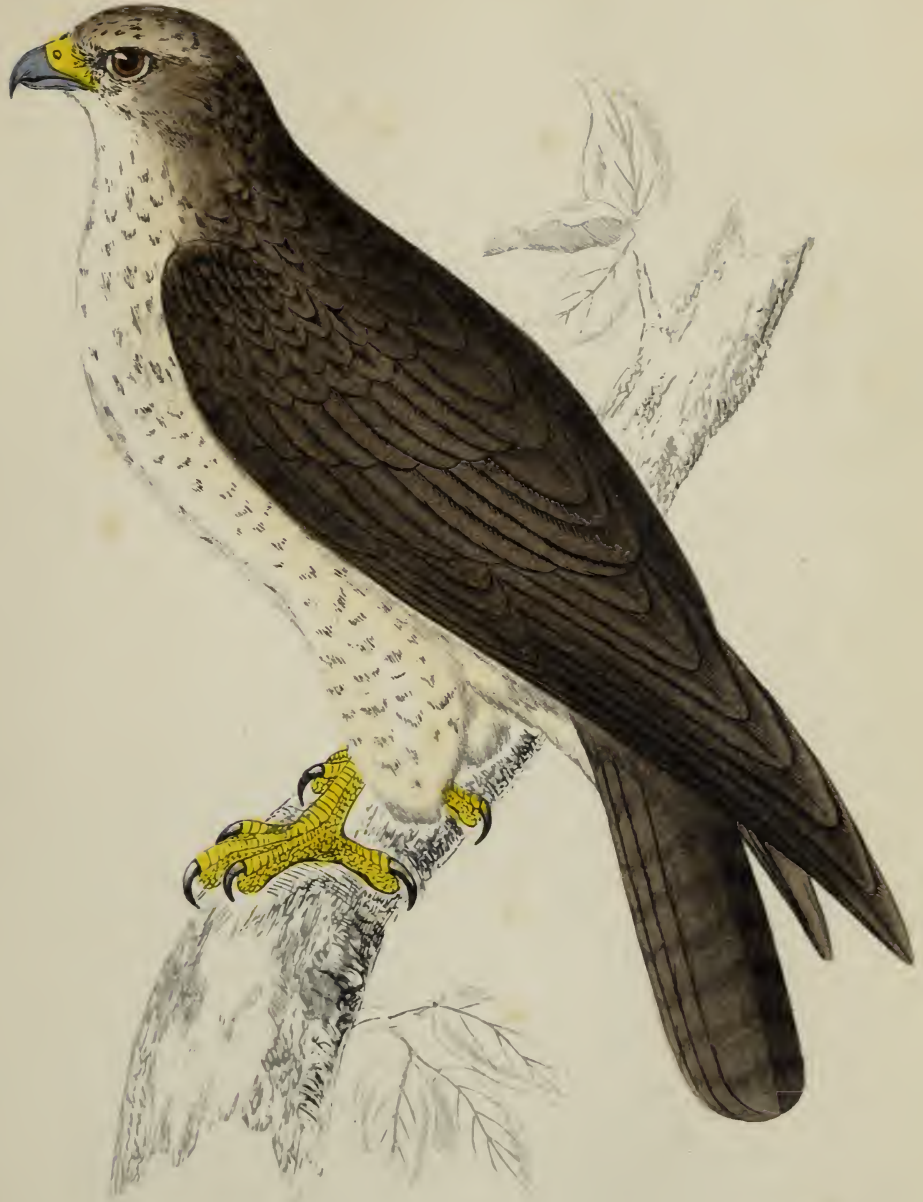



notice of the fact of its migration in this country, communicated to him in the year 1847 , by his brother, then residing at Coleford, in the forest of Dean, in Gloucestershire. I must observe that the letter was not originally intended to be published.

'Coleford, 1847.

I have a curious circumstance in ornithology to tell you. There is no account that I have heard of relating particularly to the migration of some of the Hawks, proving them to assemble in flocks for the purpose of migration, and going off together in large parties like Swallows, but of this I have positive proof in the Common Buzzard. On the 2nd. of August, 1847, just at sunset, we were assembled in the jard to the number of fire persons; we were busily engaged talking on a fine bright evening: the air was filled as far as we could see, (about forty jards to the north, and one hundred to the south,) with great Hawks, all proceeding together steadily and slowly to the westward. Those immediately above us were within gunshot of the top of the house-with large shot I might have brought some down from where I stood. The man called them Shreaks-a common name for the Wood Buzzard. The evening was so bright, and they were so near, that I saw them as plain as if they were in my hand. They were flying in little parties of from two to fire, all these little parties flying so close together that their wings almost touched, whilst! each little party was separated from the next about fifteen or twenty yards: fourteen parties passed immediately over us that I counted, but as I did not begin to count them at first, and as I have no doubt the flock extended beyond the boundary of four view, I cannot tell how many the flock consisted of. On this day a remarkable change occurred in the weather, which may have caused an early migration.'

Again, the same gentleman writing from Coleford in the following year, 1848, says-

'Coleford, 1848.

I last year wrote you a history of the migration of large parties of the Great Wood Buzzard. This year, on the 29th. of July, 1848, a party went over numbering forty, and the next day another flight of eighteen. I calculate the Hawks in three months must eat more than a ton weight of food, 
as I know that one Hawk will readıy eat more than our pounds weight of beef in a week-what can they have lived upon? there is next to no game in the forest or country anywhere.'

Whether the flights of the birds mentioned were adults moving from one part of the country to another, or young birds leaving their paternal home, in obedience to those laws of population to which even lordly man is forced to submit, it is difficult in the absence of ascertained facts, to hazard even a conjecture. Temminck has observed that the species before us migrates at certain periods of the year, and that it is at such times frequently associated with the Rough-legged Buzzard, which, if so, is rather curious.

Their flight when thus migrating appears to be slowly performed-retarded by various evolutions in the air-and many of the birds often remain for days, and even weeks together at some halting place or places on their way.

In confinement the Buzzard is easily tamed, and becomes in fact quite companionable. Various amusing anecdotes are recorded of different individuals which have been thus kept. It has generally been described as being of a slow and sluggish nature, but it is so only comparatively, with reference to some other species of birds of prey, and must not come under a wide and unexceptionable censure. According to Bewick, whom other writers seem to have followed in forming their estimate of the character of the bird before us, it is so cowardly and inactive that it will fly before a Sparrow Hawk, and when overtaken, will suffer itself to be beaten, and eren brought to the ground, without resistance. I however incline much rather to the opinion of $\mathrm{Mr}$. Macgillivray, that the Buzzard is by no means such a poltroon as he generally has had the character of being.

The Juzzard is described by some writers as flying low, but such however is by no means the result of repeated observations which I have lad opportunities of making upon it: I have almost invariably seen it flying at a very considerable elevation. Unquestionably it does, because it must, fly low, not only sometimes, but often, but that it passes no small portion of its time in lofty aerial flight, I must unhesitatingly affirm. The slow sailing of this bird, as I have thus seen it, is very striking-the movement of its wings is hardly perceptible, but onward it steadily wends its way: you can scarcely take your eyes off it, but follow it with a gaze as 
sceady as its own flight, until 'by degrees, beautifully less,' it leaves you glad to rest your eyeballs, and if you look again for it, you look in vain. When soaring aloft, the flight of the Buzzard is even peculiarly dignified, if I may use such an expression, nor do I know of any bird by which, on the wing, the attention is more immediately arrested. It looms large also in the distance, and those who have had frequent opportunities of comparing together its apparent size and that of the Golden Eagle, have said that the former may easily be mistaken for the latter, if both are not seen together in tolerable propinquity. Even when high in the air, particularly on a bright and sunny day, the bars and mottled markings on the wings and tail, the motions of which latter are also clearly discernible in steering its course, appear visibly distinct.

The flight of this species appears heavy, but is not so in reality: a series of sweeps, when, in piscatorial language, the bird is on the feed. It rises slowly at first, more after the manner of an Eagle than a Falcon, and when on the wing proceeds sedately in quest of its prey, which, when it perceives, halting sometimes for a moment, it darts down upon, and generally with unfailing precision. Its quarry is then either 'consumed on the premises,' or carried off for the purpose to some more convenient or more secure place of retreat, or to its nest, to supply the wants of its young. It does not continue on the wing for a very long time together. When not engaged in flight, it will remain, even for hours together, in the same spot-on the stump of a tree, or the point of a cliff, motionless; as some have conjectured, from repletion; and others from being on the look out for prey, at which, when coming within its ken, to stoop in pursuit. It frequents very much the same haunts, and may often be seen from day to day, and at the same hour of the day, beating the same hunting-ground.

I am inclined to think that the species of prey most naturally sought by the Buzzard is the rabbit. It feeds, however, for necessity has no law, on a great variety of other kinds of food. It destroys numberless moles, of which it also seems particularly fond, as well as field mice, leverets, rats, snakes, frogs, toads, the young of game, and other birds, worms, insects, and newts. The latter it seems to have been thought to have obtained by some means or other from their pools, but such a supposition is by no means necessary, for those little animals, like many other water reptiles, are often to be 
found wandering on dry land-out of, and far away from their more proper element. The way in which the Buzzard procures moles is, it is said, by watching patiently by their haunts, until the moving of the earth caused by their subterraneous burrowings, points out to him their exact locality, and the knowledge of it thus acquired he immediately takes advantage of to their destruction. His feet, legs, and bill being often found covered with earth or mud is thus accounted for.

The Buzzard never, or very rarely, attempts to obtain its prey by pursuit. It prowls about, and pounces down on whatever may be so unlucky as to fall in its way. Feeding, as it does, on various kinds of vermin, it is of great service in corn-growing countries, and according to Mr. Meyer, is itself esteemed a delicacy on the continent, notwithstanding the not over nice selection of its own food.

The note of the Common Buzzard is wild and striking, its shrillness conveying a melancholy idea-though, as every feeling of melancholy produced by any thing in nature must be, of a pleasing kind-when beard in the retired situations in which this bird delights. One of its local names is the Shreak, evidently derived from the sound of its note.

These birds pair in the beginning of March, at which time they may be seen wheeling about, and often at a great height abore the place of their intended abode, in slow and graceful flight. They are very attentive to their young, and are said not to drive them away so soon as other Hawks do theirs; but to allow them to remain in company with them, and to render assistance to them for some time after they have been able to fly, in the same way that Rooks and some other birds do.

The Buzzard is extremely fond, even in captivity, of the task of incubation: one at Uxbridge, a female, brought up safely several broods of chickens, to which she proved a most kind and careful foster-mother. The landlord of the inn, in whose garden she was kept, noticing her desire to build and to sit, supplied her with materials for a nest, and with hen's eggs for the purpose, and this was repeated with the like success for several years. On one occasion, thinking to sare her the trouble of sitting, he provided her with chickens ready hatched, but these she destroyed. She seemed uneasy when her adopted brood turned away from the meat she put before them to the grain which was natural to them. Several other similar instances are on record. 
The Buzzard builds both in trees, and in clefts, fissures, or ledges of mountains and oliffs, and if the latter are chosen, in the most secure and difficult situations. One in particular I remember in a most admirable recess, out of all possible reach except by being lowered down to it by a rope. The nest is built of large and small sticks, and is lined, though sparingly, with wool, moss, hair, or some other soft substance. Not unfrequently, to sare the trouble of building a nest of its own, it will appropriate to itself, and repair sufficiently for its purpose, an old and forsaken one of some other bird, such as a Jackdaw, a Crow, or a Raven, and will also occasionally return to its own of the preceding jear.

The eggs are two, three, or four in number, generally the former, and rather incline to a rotundity of form. They are of a dull greenish or bluish white, streaked and blotted, more especially at the thicker end, with yellowish or pale brown. Sometimes they are perfectly white. Occasionally their markings are extremely elegant in the eye of a connoisseur. I may here mention that I strongly suspect that many colourings of different eggs are adventitious, and not intrinsic.

Mr. Hewitson, in his very much to be praised 'Coloured Illustrations of the Eggs of British Birds,' writes, 'Mr. R. R. Wingate had the eggs of the Common Buzzard brought to him from the same place for several successive years-no doubt the produce of the same bird. The first year they were white, or nearly so; the second jear marked with indistinct jellowish brown, and increasing each year in the intensity of their colouring, till the spots became of a rich dark brown.'

The Buzzard is one of those birds which either happily or unhappily, as different naturalists may choose to consider it, varies very much in plumage-scarcely any two individuals being alike. The feathers also fade and wear much before moulting - the only permanent markings are the bars on the tail. It is the upper part which varies most in depth of tint, the general colour being brown, more or less deep or dull. In the darker specimens a purple hue is apparent. The feathers are darker in the centre, and lighter at the edges; the margin being sometimes of a pale brown, or reddish yellow. Bewick says that some specimens are entirely white, and others are recorded as nearly so. The males appear to be lighter in colour than the females. Generally they are, however, dark brown, though in some cases white prevails; the feathers being snotted in the centre with brown

Weight, from thirty to 
forty ounces; length, about one foot eight inches. The general colour of the bill is black, or leaden grey, yellow at the edges, and greyish blue where it joins the cere. The cere, which is bare above and below, but bristled on the sides, is of a greenish yellow, darker in specimens of darker colour; iris, yellowish brown, or pale yellow, but it is found to vary in some degree, according to the general tone of the colour of the bird, and sometimes approaches to orange. The head, which is very wide and flattened on the top, is streaked with darker and lighter shades of brown; occasionally with yellowish white; neck, short and wide in appearance-so much so, as, in connection with the shape of the head and the general loose character of the plumage, together with the habit of these birds of prowling for food in the evening, to have led some to suppose that an approximation is furnished by the Buzzards to the Owls.

The colour of the feathers of the neck is dusky grey, very much streaked with brown; chin and throat, white, or nearly white. The breast, greyish white, or yellowish white, also very much streaked with darker and lighter shades of brownsome of the feathers being white, with brown spots in the centre of each. In some specimens the breast is nearly as dark as the back, in others it is belted beneath with a broad band of a purple tint, and occasionally is entirely variegated with reddish brown. The back, dark brown, sometimes shewing a purple hue. Wings, large, measuring from four feet to four feet and a half in extent. They are rounded at the ends, so much so that this feature is not only clearly discernible, but a distinguishing mark of the bird when on the wing: when closed they reach nearly to the end of the tail. The tips are deep brown, shaded at the base with pure white. The wings beneath are lighter, being mottled with white and brown-they are crossed irregularly with dark bars: greater and lesser wing coverts, dark brown; primaries, brownish black; greater under wing coverts, and lesser under wing coverts, dark brown. The tail, which has six, eight, ten, or twelve narrow bars of alternate lark brown and pale greyish brown, the last dark bar being the widest, is tolerably: long, rather wide, and slightly rounded at the end: the tips of the feathers are pale reddish brown. The under side of the tail is of a general greyish white, barred with dark brown. Its whole appearance is often extremely beautiful-the upper surface being varied with a fine grey brown of different shades, and reddish yellow. Upper tail coverts, dark brown; lower tail coverts, Jellowish white, or white 
spotted with brown on each feather. The legs, which are rather short, are feathered about a third down, the bare part, which is yellow, being covered nearly all round, but principally in front, with a series of scales. The toes, bright yellow, and short-the third being the longest, and united to the fourth by a tolerably large web; the others are nearly of equal length. In specimens of this bird of dark plumage, the colour of the legs is correspondingly darker than in those of a lighter hue. The toes are reticulated to about half their length; claws, black, or nearly black, and though very sharp, not rery strongly hooked.

The female is considerably larger than the male, measuring from one foot nine to one foot ten inches in length, and nearly fire feet across the wings; sometimes as much as full fire feet. The young birds, while in the nest, are of a lighter colour than the old ones, and the tips of the feathers are paler than the rest-the whole plumage being rariegated with brown and white, and the latter predominant on the back of the neck. As they adrance towards maturity, the plumage at each moult becomes gradually of a darker hue, and at the same time the white or jellowish white markings on the throat and lower parts become more apparent and distinct. The iris is deep , brown in the immature state, and becomes of its permanent colour when the bird is adult.

'A beautiful variety,' says Mr. Mejer, 'of which there is a specimen in the Zoological Museum, is also occasionally seen, but is comparatively rare. The ground of the plumage in this rariety is white, tinged in rarious parts with yellow. The head is marked down the centre of the feathers with narrow streaks of brown; a few of the feathers on the breast are marked with arrow-shaped spots of the same colour, the smaller corerts of the wings the same. The quill feathers are dark brown towards the tips; the tail is crossed on a white ground with dark brown bars, seren or eight in number, the bar nearest to the white tip broader than the rest. In the white variety the eyes also partake of the light colour of the plumage, and are pearl-coloured, or greyish white; the cere and feet are also lighter in the same proportion, being a pale lemon yellow.' 


\title{
ROUGH-LEGGED BUZZARD.
}

\author{
Buteo laqopus, $\quad$ FLEMING. \\ Falco lagopus, PenNant,

\begin{abstract}
Buteo-............?
Lagopus, Lagöos, or Lagös-A hare. Pous-A foot.
\end{abstract}

THe Rough-legged Buzzard, says the accurate Macgillivray, may, like certain other bipeds, notwithstanding his boots and whiskers, be really less ferocious than he seems to be. This qualifying remark, however, it must be noted, is made with reference to a claim put forth in behalf of the character of this bird, to rescue it from the sweeping condemnation under which the preceding species has in like manner fallen.

The Rough-legged Buzzard is found in considerable numbers in various parts of Europe, Africa, and America. It occurs from the Cape of Good Hope, and the northern shores of Africa, to Russia, Lapland, and Scandinavia; likewise in Holland and France, and is common among the Rocky Mountains in North America, as also in North Carolina, and other parts of the United States. It is particularly abundant in some of the extensive forests of Germany, and is very frequently seen in the more cultivated districts which border on them. In England it appears to be more plentiful in the eastern and south-eastern parts, than in any others, particularly in the counties of Norfolk and Sussex, in the latter of which it is said, by A. E. Knox, Esq., to be the abundant species, as compared with the other called the common one, which latter is there but rarely met with. It is quite within my own recollection that the Rough-legged Buzzard was esteemed a very rare bird in this country; in fact, it is only within the last few years, that it has been so much oftener observed as to have become less valuable than previously on account of its supposed rarity. It is always easily distinguishable by its legs being feathered down to the toes, and by the permanency more or less, in all varieties, 




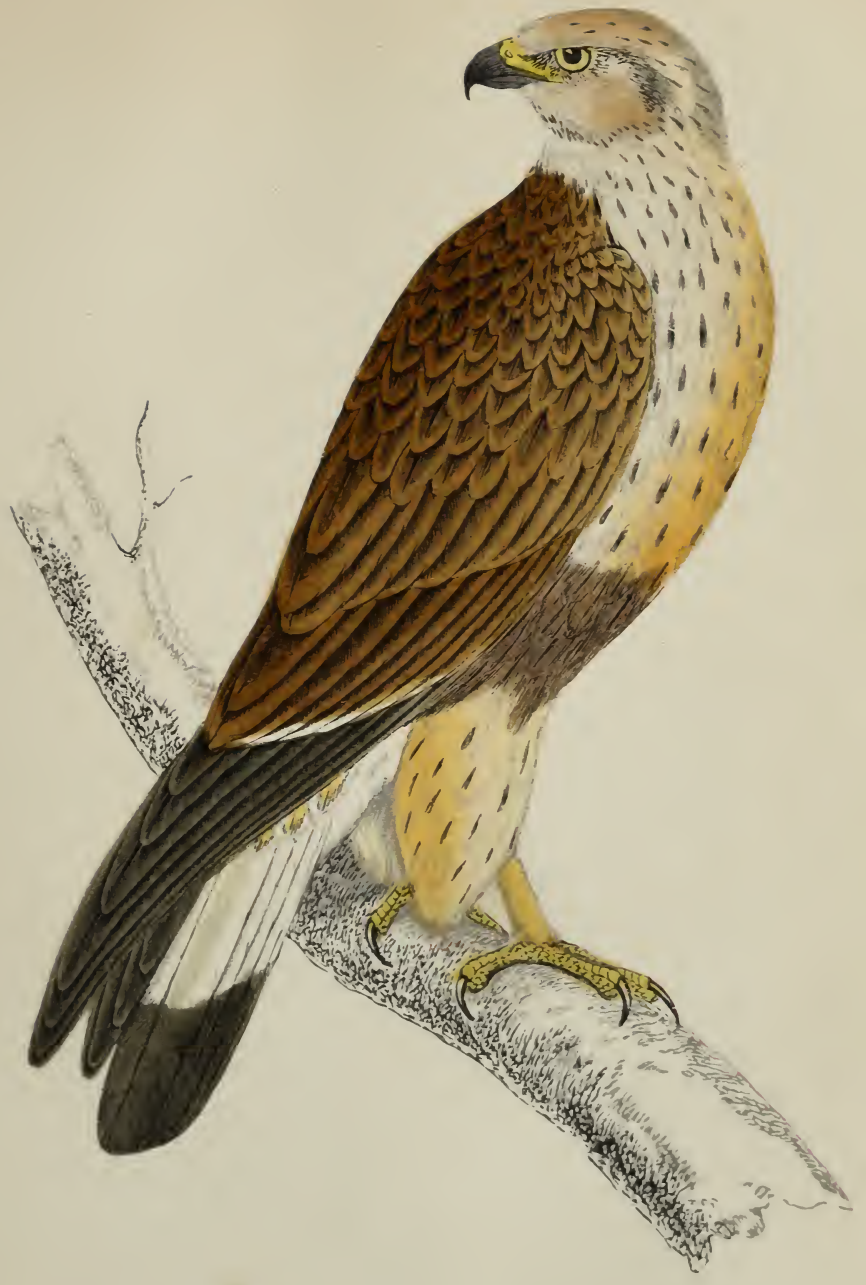

ROUGH-LEGGED BLZZABD 

of the white at the base of the tail, and, in most specimens, the white on the middle, and the dark brown patch on the lower part of the breast. It has a habit of sitting with its feathers much ruffled and loose, which gives it the appearance of being a larger bird than it really is.

Several specimens have been obtained in different parts of Ireland, as recorded by William Thompson, Esq., of Belfast, who however, considers it extremely rare there. He mentions one as having been taken alive about the middle of October, in the year 1831, near Dundonald, in the county of Down: the remains of birds, and of a rat, were found in it on dissection. Two others were seen about the same time at Killinchy, in the same county, one of which was shot, but, unfortunately not preserved. Another was shot in the autumn of the year 1836, at Castlewellan, in the same county; and another near the end of the year 1837, at Powerscourt, the seat of the Marquis of Waterford, in the county of Wicklow. Others in the southern and eastern parts of Scotland; and there is now scarce a county in England in which one or more have not been procured almost every year since attention has been directed to its specific distinction from the Common Buzzard, with which species, beyond all question, it was before continually confounded. In Yorkshire, a number of specimens were obtained near Sheffield, in the winter of 1839-40. Mr. H. Chapman, of York, has received some for preservation; and others are mentioned by Mr. Denny, as having been shot at Garforth, in the year 1s33. Two are recorded by Arthur Strickland, Esq.; one of them as having come into his own possession. It had been noticed on the Wolds for some time previously, and its flight was described as having a great resemblance to that of an Owl. Dr. Farrer reports two as having been taken in 1840: one of them shot at Clayton Heights, and the other trapped at Hawkworth Hall. One was shot at Bilham, near Doncaster, now in the possession of the Rev. Godfrey Wright, of that place, and others near Huddersfield, and at Black Hill, then a rabbit warren. For this information $\mathrm{I}$ am indebted to Mr. Allis, of Osbaldwick, near York, as well as for voluminous records of the whole of the Yorkshire Birds. To these valuable documents I shall have frequent occasion to refer, but this one acknowledgment of the favour must not be withheld.

Montagu has recorded the occurrence of a few in his time in the south of England-one of them in Kent, picked up dead on the coast, in the winter of 1792 , and Selby sereral 
as having been met with in Northumberland, in the winter of the year 1815; others in East Lothian, in 1823, and one near Alnwick, in March, 1828. In Devonshire two have been killed near Dartmoor; one at Egg Buckland, in November, 1836. Mr. Doubleday has mentioned more than fifty specimens taken in one rabbit warren, in the county of Norfolk.

This bird frequents the more wooded parts of the open country, and, if undisturbed, will continue to resort at night to the same tree, or the same wood, to roost.

The Rough-legged Buzzard remains in this country throughout the whole of the year, at least some individuals have been met with both in summer and winter. It is migratory like the species described in the preceding article, and, as there mentioned, even accompanies it in its movements, but whether its flights on those occasions are long or short-complete expatriations, or mere local removes, or 'flittings', to use a not inappropriate Yorkshire word, is a matter which at present cannot be pronounced upon with certainty. They do not always accompany the more extensive caravans of Common Buzzards, but sometimes keep to themselves in small flocks of from three to five.

It would appear that this species is more nocturnal than others of the Falcon family in seeking its prey-sometimes hawking even until long after sunset, a fact which, in connection with the looseness and softness of its plumage, has not unnaturally suggested an approximation to the Owl tribe. But, inasmuch as the Harriers approach still nearer to them in another respect, if it is to be linked with them, it must be by means of an imaginary loop-the links of the direct chain being broken, or rather superseded. That a real natural bond of union, so to call it, does exist from the highest to the lowest animal in the scale of creation, is without doubt to be received as true, but even with the materials to his hand, how shortsighted is man to trace it-how utterly blind-a mere wanderer in darkness, while all around him is light.

The flight of the species before us is, like that of the Common Buzzard, slow and stealthy. The bird is easy on the wing, and passes much of its time in hawking for its food, though it does not continue long at once in the air. Sometimes, however, it will remain for a considerable time stationary in a tree, doubtless for the same reason that actuates its predecessor (in this work.) In the breeding season it has also the like habit of soaring aloft over and around its eyrie. 
The Pnugh-legred Buzzard preys on rabbits, leverets, rats, mice, moies, frogs, lizards, birds, and insects. When instigated by hunger, it has been known to $\mathrm{fly}$ at ducks, and other larger game than the Common Buzzard aims at. In general, however, its habit is not to pursue its prey if on the wing, but to pounce on any which it may suddenly and unawares steal on. A wounded bird it will more readily fly after, conscious that it offers more certain success.

The note is a loud squeal, somewhat resembling the neighing of a foal, but, says Wilson, more shrill and savage.

This species breeds occasionally in this country, and I am happy to be able to mention Yorkshire as the county in which the fact was first ascertained, the locality being among the beautiful scenery around Hackness, near Scarborough. The nest resembles that of the Common Buzzard, being composed of sticks, and but slightl- lined. It is built, like those of other birds of the Hawk and Eagle kind, either on high trees, or precipitous and inaccessible cliffs, mountains, or rocks.

The eggs vary very considerably in colour. Some are found nearly entirely white, others of a dingy or yellowish white, more or less blotted with yellowish brown; some of a greenish white shade, spotted with pale brown, and others with reddish brown. They are from three to five in number, but generally four.

The bird before us, like the preceding one, varies also much in plumage, though not quite to so great an extent as it, the brown and the white prevailing in different individuals in a greater or less degree. The belt on the lower part of the breast, and the white at the base of the tail, are the least variable parts, but even these are by no means permanent in shape or depth of colouring. Weight, about two pounds and a half; length, from about one foot ten inches to two feet, or two feet one; bill, bluish black, or horn-colour at the base, and black at the tip; it is weak, small in size, much hooked, and has no tooth, but only a slight inclination towards.one; cere, yellow, or greenish yellow, probably according to age; iris, pale yellow, but it occasionally, as is likewise the case with the Common Buzzard, is found to rary, and is brown, or greyish white. The space between the bill and the eye is covered with short bristly feathers. The head, which is very wide and flat above, is light brown, or buff, sometimes yellowish, or yellowish white, streaked with brown. The neck, short, yellowish brown, streaked or spotted with a darker shade of 
the latter in the centre of each feather; chin, fawn-colour, tinged with rust-colour; throat, fawn-colour, or yellowish white inclining to eream-colour, and slightly streaked with brown, sometimes a mixture of fawn and rust-colour; breast, brown, with streaks, or yellowish white with spots of brown, the lower part being banded with a bar of dark brown; back, brown, the feathers being edged with a paler shade.

The wings, which measure from about four feet two to four feet three or four inches across, and reach nearly to the end of the tail-about an inch short of it-are brown, some of the feathers edged with fawn-colour; the third and fourth quill feathers are the longest in the wing, the first and second are short. The wings are partly white underneath. Greater wing coverts, pale brown, edged with dull white, or still paler brown, or yellowish white; lesser wing coverts, pale brown, edged with yellow; primaries, brownish black. The tail, which is rather long, and slightly rounded at the end, is white at the base, and irregularly barred with deeper or lighter brown near the end, which is tipped with white, the general colour being buff white on the upper half of the superior surface, and brown on the lower half; beneath, the upper half white, the lower greyish brown. In some specimens there are no indications of bars on either side of the tail, and others have only a band near the tip on the under side; upper tail coverts, white, or buff white, streaked or spotted with brown, and edged with yellowish brown; under tail coverts, yellowish white, or buff white. The legs are feathered down to the toes-this being in fact the distinguishing 'trait in its character.' The feathers are reddish, tawny yellow, or cream yellow, streaked and spotted with brown; toes, dark yellow, and rather short-the outer and middle ones are united by a membrane. They are all reticulated at the upper end, and have several large scales at the lower end, near the claws: the middle toe is said to have seven or eight, the outer one five, and the inner and hinder ones four uch; but I must here repeat the remark I have previously made. The claws, black and long, but not much hooked.

The female is considerably larger than the male-the larger measurements given above belonging to her. The lighter parts of the plumage are darker in her than in him, and the under tail coverts are spotted with brown. One variety is so very dark as to appear almost black at a little distance, and the legs and bill are darker in proportion, assuming an orange hue.

Temminck, and after him Meyer, describes a dark mottled 
variety of this species, of which the latter says that the whole head, neck, and breast, are black, the feathers bordered with reddish white; the band above the thighs white, crossed with black lines; the thighs and feathered tarsi rufous, crossed with many narrow black bars, the black occupying rather the greater portion: in these specimens the tail is white, banded near the tip with a broad black bar, above which are four or five narrower bars of the same colour. In some of them the throat and sides of the body are quite black, very narrowly streaked with yellowish white: these are considered to be the oldest birds. In autumn, after moulting, all are darker than in the summer, the plumage haring become faded.

Montagu describes another variety killed in Suffolk, having the tail of a cream-coloured white, a brown bar, above an inch in length, near the tip; above that another, half an inch broad, and above these, each feather as having a spot upon it in the middle, resembling, when spread, a third bar; the two outer feathers on each side marked with a few irregular spots of brown on the outer webs, almost the whole of their length. It was probably a male, as it measured only one foot ten inches in length.

Pennant has mentioned another, shot near London, which had the extreme half of the tail brown, tipped with dull white; but I see scarcely any variety in this from the ordinary marking of the bird, unless it be that there were no bars in the lower-the brown half of the tail. 


\section{HONEY BUZZARD.}

BOD Y MEL, OF THE ANCIENT BRITISH.

\author{
Pernis apivorus, \\ Buteo apivorus, \\ Falco apivorus,
}

Cuvier.

JENYNS.

Pennant.

Pernis-A kind of Hawk. (Aristotle.) Apivorns. ApisA Bee Voro-To devour.

THIs species is widely distributed over the earth, being found in India, and in various countries of Europe-rarely in Holland, unfrequently in France, and also in Turkey, Hungary, Italy, Germany, Denmark, Norway, Sweden, Russia, the Levant, and other parts. In Asia also, in Siberia. If the specific English name is to be considered as in any way descriptive of the bird it is attached to, it has been well observed by Mr. Macgillivray that the term 'Honey Buzzard' should be set aside for 'Bee Hawk,' as the bird does not feed on the honey, the produce of the bee, but on the bee, the producer of the honey; except therefore by a sort of recondite implication, its present name must be considered as a misnomer. There is indeed one instance to the contrary recorded by $\mathrm{Mr}$. J. T. Bold, who says that an individual of this species, kept in confinement by Mr. John Hancock, 'not only ate honey, but did so with great apparent relish, preferring it to other food.' May it not however, possibly, have been thought to be eating the honey-comb, when it was in fact only picking it to pieces, or swallowing it accidentally in search of the food which its instinct led it to expect to find in it?

One kept in a tame state by Mr. Gordon Joseph Fisher, of Newton-on-the-sea, lived in perfect amity with three Lapwings, a Seagull, and a Curlew. The one described by him ahd a quantity of moss in its stomach, which, as he very justly remarks, it had doubtless swallowed with the bees 



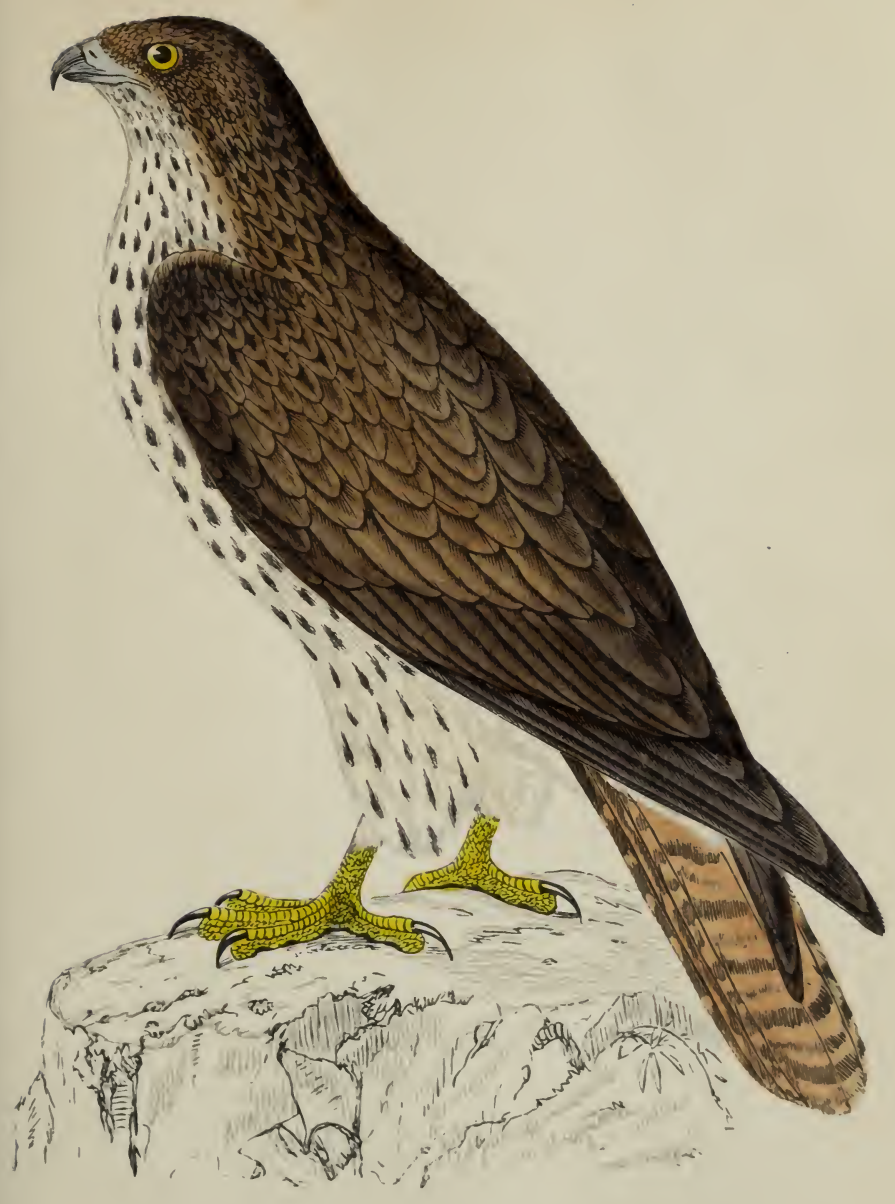



which were also found in it; yet no one would therefore contend that moss formed part of its food. It was observed by Mr. Fisher, when very hungry, to swallow pieces of comb with the larvæ in it, eating both together in its hurry; but when it was not very hungry, it used to pick the insects out, and reject the comb.

In this country many more specimens of this bird have been noticed and procured of late years than formerly, doubtless from more attention having been directed to the study of ornithology. Montagu says that in his time it was extremely rare, and he describes a specimen which was killed at Highclere, the seat of the Earl of Carnarvon, in Berkshire. The Rev. Gilbert White mentions the circumstance of a pair having built in his parish, in Selborne Hanger, (the common name in Berkshire for a wood.) Latham had only seen one recent specimen, and though Willughby says that it was tolerably common in his time, yet he most probably was not speaking with any very great accuracy. A. E. Knox, Esq. says that it is more frequent in Sussex than either the Kite or the so-called Common Buzzard. It will be observed that most of the specimens which have occurred have been on the eastern side of the island, which seems rather to confirm the supposition, suggested by the nature of its food and the season of the year it has been met with, that it is a summer visitant.

It is easily tamed, and shews little or none of the fierceness of birds of prey.

In Yorkshire, a few specimens have been met with in the East and West Ridings, more, it is said, in the neighbourhood of Doncaster, than in any other part, and it is not unlikely, as there are a great many large woods, as I well know, on all sides of that handsome town. One killed near York has the honour of being preserved in the British Museum. In the year 1849, one was obtained at Bridlington-Quay in the following curious manner:-The goodman of the house had gone to bed, and about twelve o'clock at night, he was disturbed by a beating against his window. The noise continuing, he got up, opened the lattice, and captured a fine Honey Buzzard, which had been flapping and beating against it. In Northumberland, one was killed at Wallington, and another in Thrunton Wood in the same county, in the year 1529, as recorded by the Hon. H. 'T. Liddell. One shot near Blaycion, two picked up dead on the sea shore, and two 
young male birds shot on the 26th. of August, near Hexham. These five last were procured in the year 1841. The parents of the latter two were also frequently seen. One near Twizel; one at Cheswick, near Berwick-upon-Tweed. In Sussex, A. E. Knox, Esq., in his pleasant 'Ornithological Rambles,' says that though rare, a few specimens have been met with-one in Charlton Forest; one or two near Arundel; one shot in September, in the year 1845, on Poynings Common; another obtained in the autumn of 1841, between Henfield and Horsham; and another shot in the forest of St. Leonard, by the gamekeeper of - Aldridge, Esq. Others in Norfolk, Dorsetshire, Devonshire, and Worcestershire, and, though very rarely, in Cumberland, where it has been said to have bred in the woods near Lowther. One was taken, and one shot near Yarmouth, in the county of Norfolk, in September, 1841; another at Honingham; one at Gawdy Hall Wood, near Harleston; and one at Horning, in 1841, in the same county. One in Kent, in the parish of Lydd; a few others near Tunbridge Wells; two pairs in Warwickshire, near Stoneleigh Abbey, and one in Suffolk. In Oxfordshire, a few have been recorded by my friend, (if after the lapse of so many years, 'eheu fugaces,' I may still call him so,) the Rev. A. Matthews, of Weston-on-the-Green. One of them he describes as having been taken in the following singular manner:- It had forced its head into a hole in the ground, probably in search of a wasp's nest, and becoming by some means entangled, was captured by a countryman before it could extricate itself.

In Scotland, three or four in Berwickshire, one of them about the month of June, 1845.

The Honey Buzzard frequents woods, and especially those in which water is to be met with.

The flight of this bird is, like that which is characteristic of others of the smaller species of the Hawk kind, silent and swift, a gliding through the air without apparent effort, and for the most part low. It flies generally for only a short distance, from tree to tree. When on the ground, it has been noticed by several authors, to run with great rapidity, somewhat in the way that a pheasant does. It often remains for hours together, on some solitary tree from which a good look out can be kept, and at such times has been observed to erect the feathers of the head into a sort of crest, indicative, perhaps, either of attention or sleep. 
Although it is beyond all question that the Honey Buzzard feeds at times on small animals, reptiles, and small birds, yet I feel convinced that insects are the food which is natural to it, and which it therefore prefers. This is indeed conveyed by its name, which happens in this instance, though circuitously, as before remarked, to be more appropriate than trivial names often are. Buffon says that it is itself good eating, but though it may be so in comparison with other birds more decidedly carnivorous, yet the authority of the French author will probably not have much weight with English tastes in the matter of the 'cuisine.' The larvæ of bees and wasps, found in the combs of those insects, are a favourite food with the bird before us.

The one described by Montagu, was skimming over a large piece of water, in pursuit, it would seem, of the insects to be met with in such situations, and another, at least a bird which there is every reason to believe was of this species, was observed by the Rev. Mr. Holdsworth, skimming for several successive days over a large piece of water, called Slapton Ley, in the south of Devonshire, in pursuit of dragon flies, which it seized with its talons, and then conveyed to its beak: the one mentioned before, as described by Mr. Liddell, was shot in the act of pursuing a wood pigeon. Whatever it had fed on seemed to have agreed with it, for that gentleman has described it as being so excessively fat, that the oil ran from the holes made by the shot, and that to such an extent, as to have rendered it extremely difficult to preserve the skin clean for stuffing. Rabbits, young pheasants, rats, frogs, and small birds, have been known to form the food of those birds, and even fish, when in confinement.

Its note is said to resemble that of the Golden Plover-a plaintive sound; and it has another indicative of alarm.

The young, as recorded by White of Selborne, are hatched at the end of June, so that the period of nidification must be in the month of May, or the early part of June. A female is recorded by J. P. Wilmot, Esq., in the 'Zoologist,' page 437, as having been shot off the nest in Wellgrove Wood, in the parish of Bix, near Henley-on-Thames, by a gamekeeper of Lord Camoys. The male bird kept in the neighbourhood of the nest, and was shortly afterwards shot by another of the keepers. The nest itself was also taken with two eggs, which it contained. The same gentleman also relates that both the pairs mentioned before, as procured by Lord Leigh's gamekeeper, were breeding at the time 'The 
nest of the pair mentioned by Willughby, contained two young birds; and again another, recorded by Pennant, two eggs. Of the fire specimens which I have alluded to as having been found in Northumberland, two were young birds, evidently only just come out of the nest, which was built in a wood near the place.

According to White of Selborne, the nest of this species is built in trees, in the angle formed by the larger branches, and is flat in shape. It is composed of sticks, larger and smaller, and is lined with leaves or wool, or probably any soft materials that the birds can obtain. It sometimes appropriates the old nest of a Kite or other bird as its own. 'Fools,' says the proverb, 'build houses for wise men to live in;' and the remark, it would appear, may sometimes apply to birds.

The eggs are two or three in number, and of a general dark rusty red colour, much blotted with still deeper shades of the same, somewhat like those of the Kestrel in general appearance, but very much darker. Others are but slightly dotted over at each end, the middle being belted with a dark red band; some are grey, much blotted with small spots. Others, again, are described by Temminck as yellowish white, marked with large reddish brown patches, and often entirely of that colour, or with numerous spots so close together that the white is scarcely perceptible.

This bird is of a slender and graceful form, and in many particulars fully justifies its separation by Cuvier from the preceding genus. Weight, about one pound ten ounces; length, about two feet, the males being rather under, and the females a little over that measurement. The bill, which is black and dusky, is small in comparison with those of the other Buzzards, nor is it so strong as theirs. The space between the bill and the eye is covered with short closely-set feathers, without hairs, as in most others of the Hawk tribe; cere, dusky greenish grey; iris, large and yellow, sometimes inclining to orange in the adult male. The head, which is rather flat, is very small, and looks still more so from the nature of its plumage, and this particularly, after the strikingly wide and large shape of that of the two preceding species. Its colour is a light brownish or bluish ash grey, sometimes white or cream white, the feathers in some cases being tipped with dark brown. The feathers of the neck behind are white for about two thirds of their length, and on the sides greyish brown, tending downwards 
to dark brown: sometimes the neck, like the head, is white or cream white, or pale yellowish brown; nape, dark brown or ash grey; chin, whitish; in some specimens white, as are the rest of the feathers round the base of the beak; throat, white, or yellowish white, with dark brown shaft lines; breast, white, yellowish white, or pale yellowish brown, barred transversely with broad brown bands, tinged with rust-colour, which are lighter in front, and darker towards the sides; the light feathers are tipped with bright brown; back, dark brown shaded with grey, or ash colour, the feathers themselves having a blot of a darker shade in the centre, and sometimes tipped with white, and many of them crossed by dusky marks, which cause a series of bars when the wings are closed. The wings are longer than those of the true Buzzards, and rounded at the ends; they expand above four feet; greater wing coverts, brownish grey: primaries, nearly black. The tail is very long, and in this particular, as well as in the length of the wings and the smallness of the head, this species shews an approximation to the Kites. The tip is brownish white, and the base of the feathers white, as is the case with most of the feathers on the body, if not with all. It is of a rather dark brown, tinged with grey, and barred with dark brown, but the bars vary, so that no dependence can be placed upon their number, and in some there is no bar at all; the middle feathers are the longest; tail coverts, partly white, sometimes white; under tail coverts, varied with yellowish brown and white. The legs are rather short, and feathered half way down; the lower part is a good deal reticulated, and of a dull yellow colour; toes, dull yellow. The claws, which are black, are long, rather slight, and very acute, but not much curved.

The female is larger than the male, namely, about two feet two inches: the forehead, grey; upper parts of the plumage, deep umber brown; under parts, light yellowish red, spotted with brownish red, sometimes white with dark crescent-shaped spots upon a white ground, and the upper parts barred with brown and grey.

The young are said to resemble the adult birds in colour, but Willughby describes them as covered with white down, spotted with black.

The Honey Buzzard is subject to very great variety of plumage. In the 'Zoologist,' pages 375 etc. there are figures and descriptions given by W. R. Fisher, Esq. of seven of its varieties gradually 
changing from a very dark and apparently almost black uniform colour, to nearly pure white on the breast and neck, $\mathrm{w}^{-4} \mathrm{~h}$ whice markings on the wings. One he describes as being almost entirely dark brown, with a few light spots about the neck and shoulders, and the tail as having three bars of very dark brown-the spaces between them being divided by narrower bars of a lighter tint than the former, but darker than the ground colour of the tail itself. A second, (described in a postscript, at page 795 ,) of which the predominant colour was a light brown, rather darker on the back. The feathers roun.l the neck, and also on the breast and legs, had dark margins; the quill feathers, black; secondaries, dark brown; tertiaries, lighter-all these parts exhibiting a beautiful purple gloss; tip of the tail, light yellow, barred like the other; cere, palc yellow; iris, grey. The third variety in this interesting series had the head, breast, and back of a light brown, with streaks and blots of a darker colour. The wings, dark brown with light tips; quills nearly black with light tips. The tail, like that of the first described, but more of a yellowish brown, tipped with the same. The fourth had the feathers on the top of the head and neck of a dark brown, with light tips, giving those parts a mottled appearance; round the eye, and between the eye and the bill, dark ash grey; a large patch of dark brown on the breast. The wings tipped with light brown, approaching to white on the quill feathers and secondaries; tail, as in the bird last described. In the fifth, the whole head light ash grey; wings, dark brown tipped with a lighter shade of the same; all the under parts white barred with brown. The tail, nearly like that of the last, but with a fourth bar, or several patches in the form of a bar, at the upper end, tipped with light yellow brown. The sixth had the forehead white; breast, white, with some patches of brown; round the eye and between it and the bill, dark ash grey; neck, white, with some dashes of brown; upper part of the wings, white, slightly dashed with brown; secondaries and tertiaries, brown tipped with white. The tail, barred with two shades of dark brown, and tipped with light brown. The seventh had the wings alone tipped with white, as also the secondaries and tertiaries, the under parts without the brown patches, and the dark streaks much narrowed. The tail as in the last.

Variations of plumage occur in this species as in so many others. In one described by Montagu, the breast was light brown; and in another, described by the Hon. H. T. Liddell, 
all the under part was dark brown. Some have the head of a uniform ash grey; and A. E. Knox, Esq. describes two, one of them as having the upper part of the head, the wings, and tail of a dark brown, and all the rest of the plumage of a beautiful cream white, or light straw-colour; the other as much resembling a Cuckoo in general appearance. Sometimes the whole plumage is strongly glossed with a purple tint. One is described by Temminus, having the head, neck, and all the under parts, yellowish, with dark shafts to the feathers. 


\section{ITTS.}

PUTTOCK. FORK-TAILED KITE. GLEAD.

BAREND, OF THE ANCIENT BRITISH.

Milvus regalis,

Falco milvus,

Milvus Ictinus,

"vulgaris,

MIilvus-A Kite.
Brisson.

LINN AEUS.

SAVIGNy.

Fleming.

Regalis-Royal-regal.

The Latin and English names of this species are, to say the least, inconsistent with each other, the word 'Kite' being equivalent in our language to the word craven or coward, and the term 'Royal' being inseparable from the idea of spirit and bravery. Buffon however asserts that the name 'Royal' has been given to it, not from any supposed royalty in itself, but because in former times it was considered royal game.

The Kite is common throughout Europe, being found even in very northern latitudes. It inhabits Italy, France, Switzerland, and Germany; is very uncommon in Denmark, Sweden, Norway, Russia, and Siberia; and is met with, though rarely, in Holland. It is also found in various parts of the north of Africa, and over the greatest part of Asia. Clusius relates that these birds were formerly very abundant in the streets of London, and very tame; it being forbidden to kill them on account of the use they were of, in acting the part of scavengers.

The Kite is described by authors as being local in this country, and strange indeed would it be if it were not. Where is a bird of its size, and of its handsome aprearance, and which is moreover so easily caught in traps, and so destructive of geme, to remain incognito, or in safety in these days? The marvel is that a single specimen survives, 'sola 




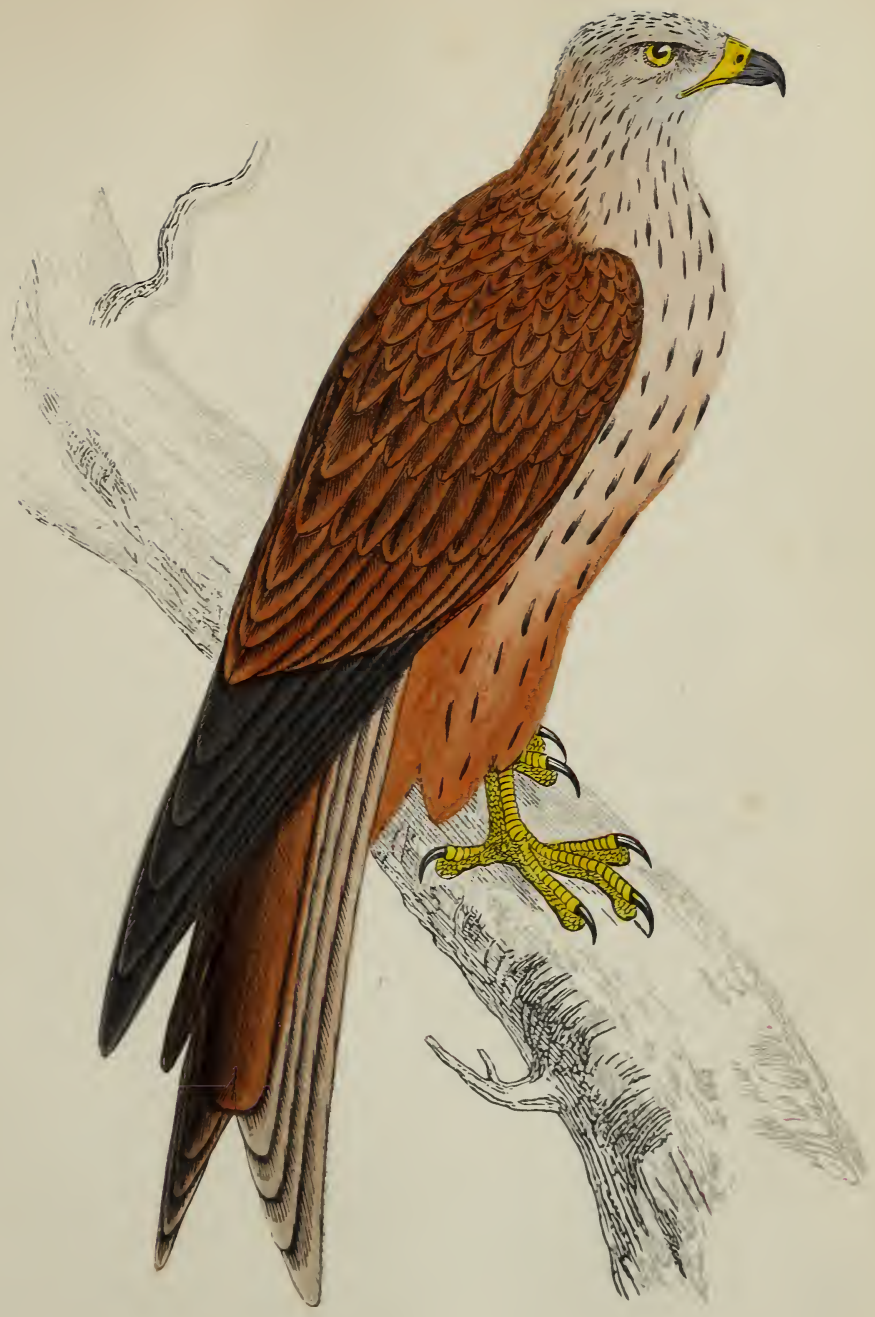



superstes,' as a living monument of the former existence of its kind. In these times of so-called 'progress' it is, however, to be feared that even this state of things may not continue -no 'Aborigines protection society' exists for the Kite.

In Yorkshire, the Kite has been in former times far from uncommon, but the following are all that are now on record. About twèty-five years ago, one was caught in a trap at Edlington wood, near Doncaster, and a pair were taken from the nest by Mr. Hugh Reid, of that place. One was obtained at Hornsea wood, in 1833, and another in Lunn wood, both near. Barnsley, in 1844. It has been observed, but very rarely, near Halifax, and one was seen by Charles Waterton, Esq., near Huddersfield. Others by Sir William Jardine, Bart., and one by Mr. W. Eddison, near Penistone, but there is no notice, that I am aware of, of any having been met with in the North or East Ridings. Not far from Alconbury hill, a well-known place on the old 'Great North' road, (how different in all but name from the 'Great Northern,') - a locality in which I perceive that $\mathrm{Mr}$. Hewitson records that he has seen it, I had the pleasure some years ago of seeing the Kite on the wing; too striking a bird, when once seen, not to be easily recalled at bidding before the mind's eye.

In addition to the before-named places, this 'Royal' bird has been a dweller in several parts of Wales, and of Scotland. Many have hitherto found a temporary refuge in various parts of the 'far north.' The waters of Loch Awe have reflected the graceful flight of some, and the 'burnished gold' of Loch Katrine has been darkened by the passing eclipse of others. In Sussex it was, says Mr. Knox, indigenous in former times, but is now no longer known there, only one near Brighton, and one near Siddlesham, having occurred within the last ten years. In the Hebrides it appears to be unknown. In Sutherlandshire it is becoming very rare, though formerly common. On the banks of Loch Fine it is said by Sir William Jardine, to be more abundant than in any other quarter of the country, on Ben Lomond, as also in many parts of the western Highlands, Aberdeenshire, Stirlingshire, Nairneshire, and Argyleshire, but only north of the Forth, being almost entirely unknown in the south of Scotland. Mr. Macgillivray says that in the space of eight years only one specimen came into the hands of the Edinburgh bird-stuffers. In the New Forest in Hampshire, it has hitherto been frequently seen. In Devonshire it seems to be very rare: Montagu only observed 
one there in the course of twelve years; one was caught on Trowlsworthy Warren, Dartmoor; one at Widey, in 1831; one at Saltram; and one at Sydenham, in 1835. A few in Durham, Cumberland, Westmoreland, Essex, and Hertfordshire: very rarely in Gloucestershire-between Gloucester and Bristol, according to Mr. Knapp.

It is said by J. J. Briggs, Esq., in his catalogue of the Birds of Melbourne, to be there sometimes seen sailing over the grass fields at a considerable height, in a steady and graceful manner; and the Rev. Messrs. Matthews, in their catalogue of the Birds of Oxfordshire, say likewise, that a few years ago it was so common there, that occasionally two or more might be seen at the same time about its favourite haunts, but that it has now become very scarce.

In Ireland, it is stated by Smith, in his history of Cork, which was completed in the year 1749 , to have been at that time common. Now, however, it is said by William Thompson, Esq., of Belfast, to be known only as a very rare visitant. The Rev. Joseph Stopford has seen it at Ballincollig Castle, in 1827, and near Blarney. In the park of Shanes Castle, the seat of Lord O'Neil, two were seen by Mr. Adams, his Lordship's gamekeeper, one about the year 1830, and the other in March, 1835. Others are said to have been observed in the same park in previous years; and one was once seen by William Ogilby, Esq., in the county of Londonderry.

It retires in great numbers from the north of Europe to Egypt and the northern shores of Africa, before winter, staying there to breed, and returning again in April to Furope, where it breeds a second time, contrary to the nature of rapacious birds in general. It remains with us the whole year, but may be, and indeed probably is, partially migratory.

The flight of the Kite is rapid, and, like :everal other birds of prey, it soars at times to a vast heigit, and there frequently remains for hours together, seemingly in the tranquil enjoyment of its easy exercise; sometimes it ascends beyond the reach of human vision: doubtless, however, its sight far excelling ours, it can perceive objects in the 'vast profound;' and at times it descends from a great altitude upon its prey, with astonishing swiftness. One of the vernacular names of this bird, the Glead or Gled, is derived, according to Pennant, from the Saxon word 'glida,' descriptive of its gliding motion. Wheeling round and round, supported on its extensive wings, and guided by the steering of its wide tail, it thus by degrees 
advances, sometimes for a time poising itself in a stationary position. If its nest is attacked or approached, it dashes in a wild manner around and near its enemy, supposed or real, with screams, either caused by alarm for its young, or intended to excite fear in its assailant. When searching for prey, it ilies at a moderate height from the ground, at an elevation of from about twenty to about one hundred feet, performing a variety of sweeps and curves, and appearing, as indeed at other times, to be not only guided, but almost partially supported, by its wide-spread and expansive tail, which it moves about from side to side. Buffon (quoted by Macgillivray) says of its flight, 'one cannot but admire the manner in which it is performed; his long and narrow wings seem immoveable; it is his tail that seems to direct all his evolutions, and he moves it continually; he rises without effort, comes down as if he was sliding along an inclined plane: he seems rather to swim than to fly.' Frequently, however, his flight is unsteady and dashing, strongly resembling that of several of the Seagulls.

The food of this species consists of small quadrupeds, such as leverets, moles, mice, rats, and rabbits; game, and other birds, especially the young; frogs, lizards, snakes, worms, insects, and occasionally carrion, and it is said by Bewick that it is particularly fond of chickens, but that the fury of the mother is generally sufficient to scare it away. In search of these, it, like the Sparrow-Hawk, sometimes approaches the poultry yard, but doubtless such approaches were far more common in former times than now. Montagu, however, in his Ornithological Dictionary, gives an account of one which was so eager in its attempt to obtain some chickens from a coop, that it was knocked down by a servant girl with a broom; and he relates that on another occasion, one of these birds carried off a portion of some food which a poor woman was washing in a stream, notwithstanding her efforts to repel him. They have been known to feed on fish, the produce of their own capture from a broad river, and will readily devour the reliques of a herring or other fishery.

The Kite, like the Buzzards, and unlike the Eagles and Falcons, does not pursue its prey, but pounces down unawares upon it.

Its note is called by gamekeepers and others its 'whew', a peculiarly shrill squeal.

The author of the 'Journal of a Naturalist,' has the fol- 
lowing curious account in his entertaining and profitable book. He says, 'I can confusedly remember a very extraordinary capture of these birds when I was a boy. Roosting one winter evening on some very lofty elms, a fog came on during the night, which froze early in the morning, and fastened the feet of the poor Kites so firmly to the boughs, that some adventurous youths brought down, I think, fifteen of them so secured! Singular as the capture was, the assemblage of so large a number was not less so; it being in general a solitary bird, or associating only in pairs.'

In the breeding season it is a common thing to witness conflicts between the male birds. Montagu speaks of two which were 'so intent on combat that they both fell to the ground, holding firmly by each others' talons, and actually suffered themselves to be killed by a woodman who was close by, and who demolished them both with his billhook. It also at such times approaches the villages, which at other times it avoids, perhaps searching for materials for its nest. The young are defended with some vigour against assailants. The hen sits for about three weeks, and during that time is diligently attended to by the male bird.

The nest is built early in the spring, between the branches of a tall tree, but rather in the middle than at the top, and occasionally on rocky precipices, and is composed of sticks, lined with any soft material, such as straw, hair, grass, wool, or feathers. It is flat in shape, and rather more closely compacted than that of some other birds of the Hawk family, and is generally built in the covert of a thick wood.

The eggs of the Kite, which are rather large and round, very much resemble those of the Common Buzzard, and possibly this fact may afford some confirmatory justification of the juxtaposition of these birds. The ground colour is a dingy white, bluish or greenish white, or dull brownish yellow, and in some instances unspotted at all; in others it is dotted minutely over with yellow or brown, or waved with linear marks, and in others is blotted here and there with brown or reddish brown, but especially at the lower end. They are generally two or three in number-rarely four.

This handsome and fine-looking bird weighs light in pro portion to its apparent size, so that it is very buoyant in the air: its weight is only about two pounds six ounces, or from that to two pounds and three-quarters; length, two feet two inches, to two feet and a half; bill yellowish, or yellowish 
krown at the base and edgr and dusky or horn-colour at the tip. In extreme age it : becomes of a yellowish colour; cere, yellow; iris, yellow; br.stles are found at and about the base of the bill. The head, dull greyish white, light yellowish brown, hoary, or ashy grey with brown or dusky streaks in the middle of each feather along the shaft; the feathers are long, narrow, and pointed. In some specimens the head is rufous. The feathers of the neck are also long and pointed, which give a kind of grizzled appearance to that part; it is light yellowish red in front, each feather being streaked with dark brown, and the tip reddish white; nape, chin, and throat, greyish white; breast, pale rufous brown, each feather with a longitudinal streak of dark brown; back, reddish orange, or rufous brown, with dusky or dark brown stripes in the centre of the feathers, the margin of each being pale, or dusky, edged with rust-colour; the breast is lighter than the back, and specimens vary much in depth of colour in both parts.

The wings extend to fire feet, and, when closed, two inches beyond the tail, the quill feathers are dusky black, from the fifth to the tenth dashed with ash-colour, with a few dusky bars, and white at the base and on the inner webs; the rest are dusky with obscure bars; of the tertiaries some are edged with white: the under surface of the wings, near the body, is rufous brown with dark brown feathers, edged with reddish brown towards the outer part of the wing. The feathers of the greater wing coverts are dusky, edged with rust-colour; the two outer primaries, nearly black; the others greyish brown on the outer web, and paler, barred with blackish brown on the inner: the fourth quill is the longest, the third only a little shorter, the fifth nearly as long, the second a good deal shorter, and the first much shorter than the second; secondaries, greyish black, or deep brown, shaded with purple, the tips, reddish white, the inner webs more or less mottled. The tail is the distinguishing feature in this bird, as the legs are in the Rough-legged Buzzard: it is both wide and long, and very much forked. The bird may by it be 'challenged' at any distance from which it is brought in sight. Its upper side is reddish orange, or bright rust-colour with white tips; and beneath it is reddish white, or greyish white, with seven or eight obscure brown bars. The middle feathers are a foot long: the outer ones between fourteen and fifteen inches. 'The two outerm sst, which turn slightly outwards at the tip, are dusky on the outer webs; the first barred on the inner web with 
the same. The bars on the upper surface shew through to the under; unper tail coverts, rufous, $\wedge r$ reddish orange; under tail coverts the same; legs, yellow or orange, short, scaled, and feathered about an inch below the knee. The toes are small in proportion to the size of the bird: the outer and middle ones are united by a mcmbrane; claws, black, or bluish black, and not much hooked.

The female is considerably larger than the male; length, two feet four inches. Her plumage inclines more to grey and orange than his. The feathers on her head become gradually more grey, until they fade to a pale hoary white. The young, when first fully fledged, are of a deep red, especially on the back, and the central markings of the feathers are darker and larger than in the adult bird; the head and neck are also darker. The iris is yellowish brown; the feathers on the back have a tinge of purple; the bars on the tail are more distinct, and the colour of it is darker than in the old bird.

After the first moult, the young birds nearly acquire their perfect plumage. The central dark markings on the feathers become less, and their red edges paler with advancing age.

The varieties of this species as to size and colour, though not unfrequent, are unimportant. 



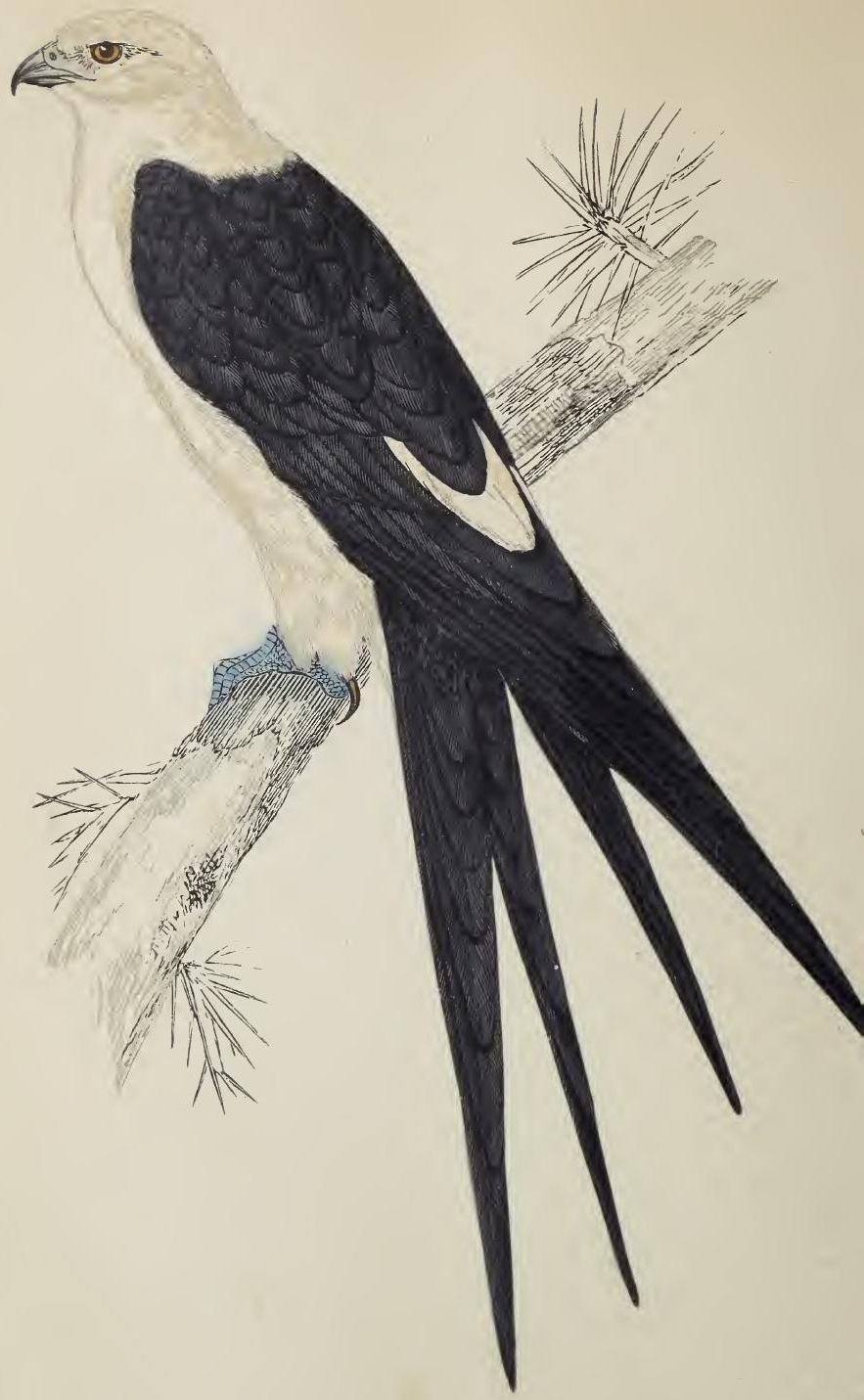





\section{SWALLOW-TAILED KITE.}

\author{
Elunus furcatus, \\ Milvus furcatus, \\ Nauclerus furcatus, \\ Falco furcatus,
}

Fleming.

JENYNS.

Gould.

IVILSON.

Eilanus-Perhaps from Elaunö-To drive or chase.

Furcatus-Forked.

Trus elegant species is very abundant in the southern and south-western states of America-to the extensive prairies of the latter of which it is peculiarly attached, and becomes much loss frequent towards the north, particularly on the eastern side of that continent. It is found also in Peru and Buenos Ayres.

Two specimens only have as yet occurred in this country, driven over probably by tempestuous winds. One of them was killed in the year 1772, at Balachoalist, in Argyleshire, and the other was captured in Wensleydale in Yorkshire, at Shaw-gill, near Hawes, on the 6th. of September, 1805. The 'pitiless pelting' of a tremendous storm, and the simultaneous buffetings of a flock of Rooks, drove it to take shelter in a thicket, in which it was caught before it was able to escape. It was kept by the person who captured it, for a month, but it then made its escape through a door which had accidentally been left open. It alighted for a short time on a tree not far off, from which it soon afterwards rose upwards spirally to a vast height, and then, guided by its instinct, went off in a southerly direction as long as it could be observed. These facts are recorded in the fourteenth volume of the 'Linnæan Transactions,' in a letter from W. Fothergill, Esq., of Carrend, near Askrigg, the next town to Hawes.

The Swallow-tailed Kite is migratory in those countries of which it is an inhabitant, visiting certain parts in the spring to breed, and leaving them again in the autumn.

The flight of this bird is singularly easy and graceful, as 
its whole appearance at once indicates. Its airy evolutions are described as being most remarkable, its tail directing them in a peculiarly elegant manner. They are engaged in flight, generally, like their miniature effigies, the Swallows, throughout the day, so that except when on their migrations they are not easily approached.

The Swallow-tailed Kite always feeds on the wing. In fine weather they soar to a great height in pursuit of large winged insects, which seem to form their favourite food, grasshoppers, locusts, cicadæ, and caterpillars, bees, wasps, and their larvæ in the comb, as well as flying insects, being extensively preyed upon by them. They also, however, devour small snakes, lizards, and frogs. In search of their terrestrial food, they sweep closely over the fields, and alighting, or rather seeming for an instant to alight to secure any whieh they may have observed, bear it off, and devour it in the air, feeding themselves with their claws. Meyer says that they sometimes take their prey off the branches of trees, as they fly among them.

The note of this species is described by Audubon as sharp and plaintive.

The pairing time is in the beginning of April, and the male and female sit alternately, each in turn feeding the other. They have only one brood in the year.

The nest, which is composed of sticks, and lined with grass and feathers, is usually built on the top of a tall tree, and the vicinity of water is preferred, probably on account of the insects to be found there.

The eggs are from four to six in number, of a greenish white colour, irregularly blotted with dark brown at the larger end.

Length, one foot eight inches, and from that to two feet, and even upwards; bill, bluish black; cere, light blue, and covered at the base with bristles; iris, silvery cream-colour, surrounded with a red ring; head, crown, nèck, nape, chin, throat, and breast, pure white. The back, wings, and wing coverts, black, with a metallic green and purple lustre. The greater part of the plumage is white at the base, which sometimes gives the bird a mottled appearance. The tail is of a black colour, glossed with green and purple, and very deeply forked; upper tail coverts the same colour; under tail coverts, white. The legs, which are short and thick, are feathered in front half way below the knee, are, like the toes, 
greenish blue. The claws, which are much curved, the outer one being very small, are dull orange, or flesh-colour.

There is little if any difference in colour between the mals and female. The young are at first covered with yellowish down; afterwards they assume the distinct divisions of colour of their parents, but do not acquire the metallic lustre until arrived at maturity. The outside feathers of the tail do not roach their full length until autumn, so that it is gradually becoming more and more forked until then. In the following spring the whole plumage is complete. 


\section{JER-FALCON.}

\section{Falco Islandicus, \\ " Gyrfalco, \\ Gyrfalco candicans,}

LATHAM.

LiNNEUS.

Flemisg.

\section{Iulco - To cut with a bill or hook. 1slandicus-Of, or belonging}

I Axr compelled to say 'not proven,' with reference to the arguments of $\mathrm{Mr}$. John Hancock, read before the British Association at Newcastle, with a view to establish the supposition that two species are confounded together in the one bird before us. It may, I think, be depended upon that the white plumage is the token of advanced age, as the dusky brown is of youth. The indentations on the bill are unquestionably alterable, and as to the specific difference endeavoured to be established from the bars on the tail, both the varieties have been found in one and the same individual specimen.

This noble bird may well be regarded as the personification of the 'beau ideal' of the true Falcons, at the head of which it pre-eminently stands. Its courageous spirit, together with its rarity even in its native countries, and the difficulty of procuring it, made it highly estimated in the days of falconry, as it was qualified and disposed to fly at the larger kinds of the 'game' of those days, such as herons and cranes. Its education was indeed difficult, but it was sure to repay the patience and perseverance required for training it for the aristocratic pastime, so highly thought of in the olden times.

I am indebted to J. Mc Intosh, Esq., of Milton Abbey, Dorsetshire, for a quaint old treatise on the subject of Hawking, as one of other former 'countrey contentments,' but I am obliged, against my will, to omit much which I should be glad, if space permitted, to insert. My thanks however are not the less due to him, and other obliging correspondents. 



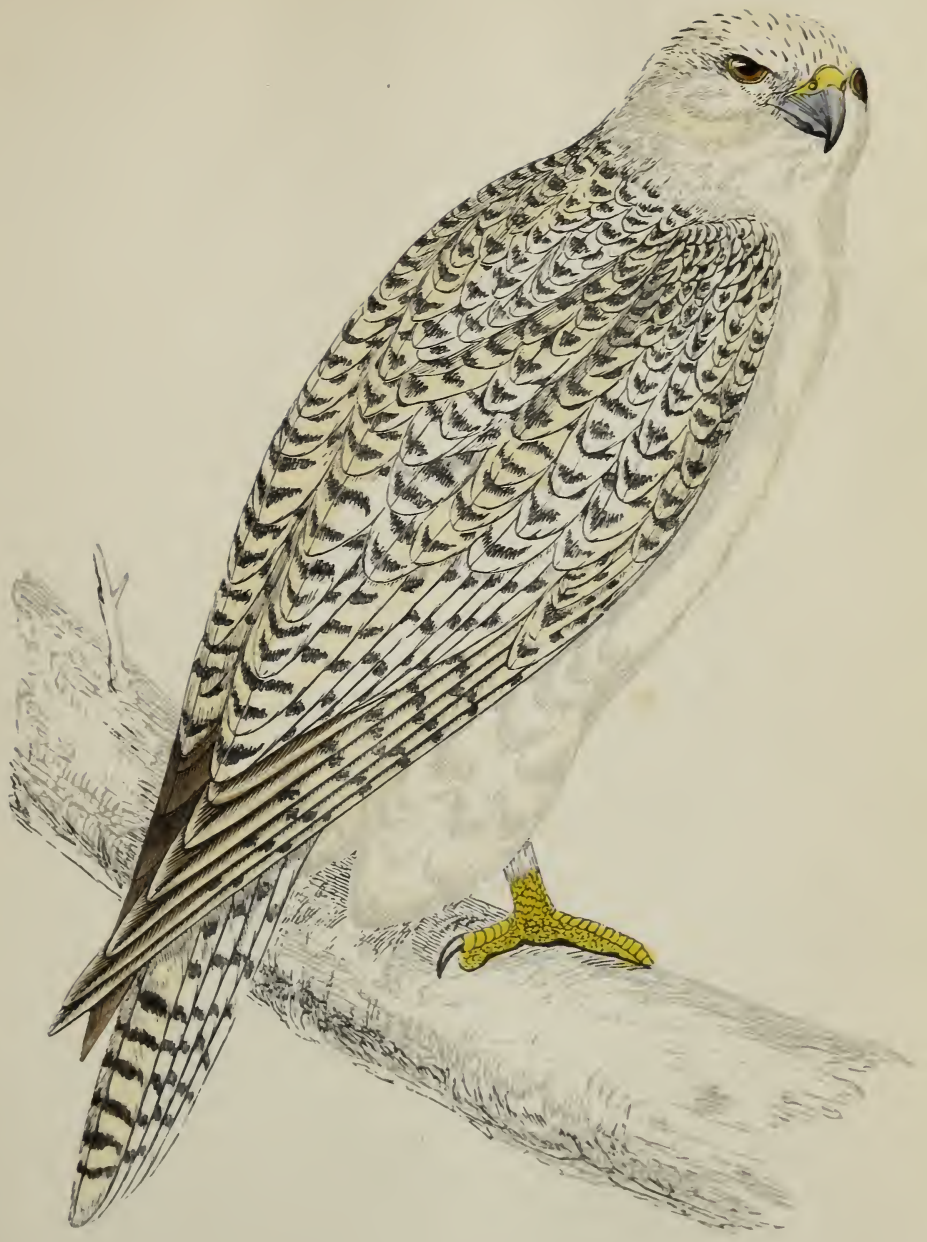



The hyperborean regions are the native place of this Falcon: thence indeed its specific name. It occurs in the Shetland and Orkney Islands, but is considered by Mr. Low, in his 'Fauna Orcadensis', to be only a visitant even there, and not a permanent resident. Iceland, Greenland, and the parallel parts of North America, and Northern Asia, are its proper haunts, as also Norway, Russia, and Lapland, and it is occasionally met with in the northern parts of Germany, and the south of Sweden. In Asia too, in Siberia.

The Jer has been but rarely killed in this country: a few in Scotland, and still fewer in England, Wales, and Ireland.

In Yorkshire, one is said to have been obtained in the year 1847 , in the month of March: another was shot in the year 1837, March 13th., in the parish of Sutton-upon-Derwent, near York, and was kept alive for some months by Mr. Allis, of York, after refusing food for the first three or four days. Another in the year 1837, in the middle of the month of March, on the moors near Guisborough, in Cleveland. It was a young bird. One was shot in Devonshire, on the Lynher river, in the month of February, 1834. Polwhele has also noticed this specimen. A young bird was killed in the parish of Bellingham, in Northumberland, in the middle of January, 1845. Two are recorded by Thomas Edmonston, Jun., Esq., as having been killed in Shetland, where he also says that it is only a straggler. The Rev. J. Pemberton Bartlett, speaks of it as 'rare' in Kent. One was seen by the Rers. A. and H. Matthews, on the 10th. of October, 1847, near Tetsworth, in Oxfordshire, in the act of devouring a wood-pigeon. They observed it again a few days afterwards near the same spot. Another had been shot a few years previous near Henley-onThames; both of these were in immature plumage. Another was caught in a trap some years ago near Brigg, in Lincolnshire, on a rabbit warren named Manton Common I believe; one in Pembrokeshire, on the estate of Lord Cawdor; and another on Bungay Common, in the county of Suffolk; one was shot in the county of Northumberland; one seen by Mr. Bullock, in Stronsa, one of the Orkney Islands; one near Aberdeen, and one killed in Sutherlandshire, in the winter of 1835. In the same year above mentioned, 1847, one was seen by W. M. E. Milner, Esq., M.P., near Thurso, in Caithnesshire.

In Ireland, but three specimens have occurred, (described as being of the other supposed specics,) one on the wing over 
a rabbit warren, near Dunfanaghy, in the county of Donegal; another near Drumboe Castle, in the same county; and the third in the year 1803, near Randalstown, in the county of Antrim.

The flight of the Jer-Falcon, which resembles that of the Peregrine, but is more lofty and swifter, is astonishingly rapid: it has been computed that this bird flies, when at its speed, at the rate of one hundred and fifty miles an hour. It is said to use its wings with more action than is required in the sailing motion of some species. It captures its prey by rising above them, hovering for a moment, and then descending upon them, and generally with unerring aim; not, however, perpendicularly, but with a literal stoop. If it misses its first stroke, it again ascends over its victim, and repeats the attack.

The food of this species consist of the smaller animals and the larger birds, such as hares and rabbits, geese, grouse, partridges, whimbrels, curlews, guillemots, ducks, plovers, and other sea and land fowl.

The Jer-Falcon breeds not only in the highest and most inaccessible rocks, but also occasionally in cliffs which are of lower elevation, both those of the sea-coast and those of inland lakes, and when engaged in the task of incubation, is particularly daring in attacking any aggressor.

The nest is composed of sticks and roots, and is lined with wool, moss, sea-weed, or probably any soft substance surtable for the purpose which the builder can procure. It is supposed to be in the habit of appropriating to itself the deserted nests of other birds.

The eggs are believed to be of a light yellowish brown colour, dotted with rusty red, with here and there an occasional patch of the same; or dull white, mottled all over with pale reddish brown. They are said to be two or three in number.

It is impossible not to be struck by the general resemblance of this species, especially in plumage, and partially also in shape, to the Snowy Owl, its noble companion in the icy regions of the north. When of full age the whole plumage is white. I have seen perfectly immaculate specimens in the possession of Mr. Hugh Reid, of Doncaster. 'The whole plumage is close and well set. Length, from twenty-two inches to two feet; bill, rather short, but thick and strong, much hooked, and of a pale blue or greenish grey colour. Much stress has been laid upon the tooth, as it is called, as establishing a specific 
difference, but 'me judice' it is by no means an unfailing mark, being worn down by attrition, and varying in different individals; cere, dull yellow; iris, dull reddish brown.

The female resembles the male, except in size, being rather larger, and the spots are broader, especially on the breast and sides. In the young bird the bill is dark blue, tipped with black; cere, bluish; iris, dark brown. All the upper parts are of a brown ash-colour; the feathers being edged with white: a dark streak descends from the corner of the bill down the side of the throat: all the feathers are margined with paler colour. The wings, nearly as long as the tail; the under parts brown, gradually becoming white, with large longitudinal brown spots; tail, barred with light brown; legs, greyish blue, or blue tinged with yellow; claws, dusky.

In birds of less mature age, and which are by far the most ordinarily met with, the head, crown, and neck are pure white, or white with a few brownish black spots or streaks; the latter is rather short and thick, at least in its plumage, in some degree in this respect resembling the Owls. The nape, chin, and throat, pure white; breast, white, or slightly spotted or lined as the other parts; back, more or less spotted and mottled with blackish brown. The wings are rather long, being, when closed, about four inches shorter than the tail; the second and third, and the first and fourth quills are respectively of nearly equal length; primaries, white, their tips dark and narrowly edged with white; larger and lesser under wing coverts, pure white. The tail, long, and slightly rounded at the end. In some specimens it is white, and in others barred alternately with blackish brown and white, or greyish white; the outer feathers are about half an inch shorter than those in the centre; tail coverts, white. The legs, bright yellow, or bluish grey, according to age; (Montagu says bluish ash-colour, and Bewick pale blue, but this is in the young bird;) they are short and robust, feathered more than half way down, and covered in front transversely with oblong scales, and behind with small round scales; toes, yellow, and covered with small scales; the second and fourth are nearly equal in length; the third the longest; the hind one the shortest: underneath they are very rough. The claws, black and strong; the hind one being the longest.

Montagu describes a bird, which he says appears to be a variety of this species, as follows:- 'It is white, with a few vol. $I$. 
scattered spots of dusky black on the upper part of the body and the head streaked with the same; the wings and tail, black, the latter with a band of white at the end, and a little white at the base; the quills slightly tipped with white; the secondary quills and under coverts elegantly barred with black and white. The wings were very short in proportion to the size of the bird, for if the primary quills had been closed, they would artainly not have reached near the end of the tail.' 



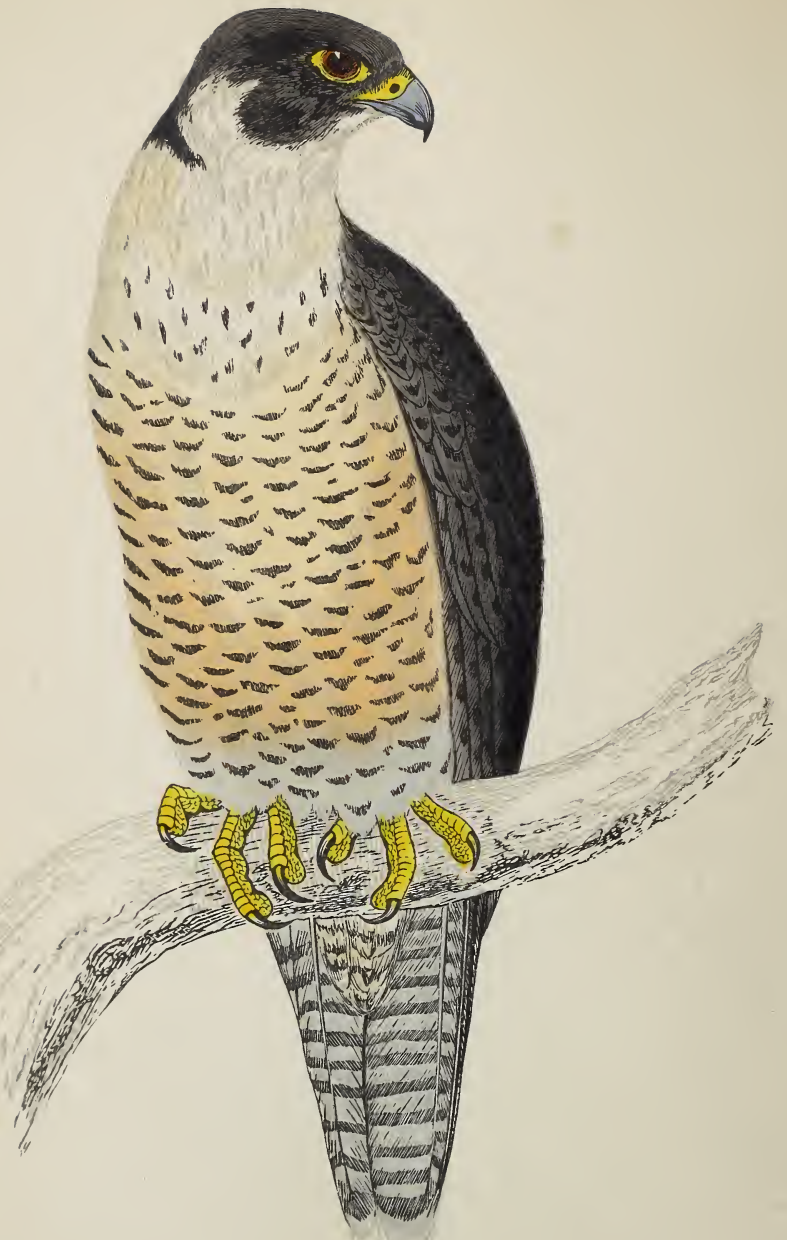

PEREGRINE. 



\section{PEREGRINE.}

Falco peregrinus, Fulco communis,
Latham. Fieming.

Latham. Selby.

Falco-To cut with a bill or hook. Peregrinus-A stranger or foreigncr -a traveller from a distant country.

The Peregrine-Falcon has always been highly prized both living and dead, in the former case for its value in falconry, on account of its courageous spirit and docility, combined with confidence and fearlessness, and in the latter for its handsome and fine appearance. It is a bird of first-rate powers of flight, and from its frequent exertion of those powers has derived its name. It has very often been seen crossing the Atlantic at a great distance from land.

The Peregrine is widely distributed, being found throughout the whole of North America, and in parts of South America, even as far south as the Straits of Magellan, and northwards in Greenland; in Africa, at the Cape of Good Hope; in most countries of Europe, particularly in Russia, Denmark, Norway, Sweden, and Lapland; in Siberia and many parts of Asia; and also in New Holland. The rocky cliffs of this country have hitherto afforded it a comparative degree of protection, but 'protection' seems exploded-explosion in fact sounding the knell of the aristocratic Peregrine.

Strange to say these birds have been known to take up a temporary residence on St. Paul's Cathedral, in London, anything but 'far from the busy hum of men,' preying while there on the pigeons which make it their cote, and a Peregrine has been seen to seize one in Leicester Square.

In the county of York many of these birds have at different periods been shot, some at Nutwell and Flamborough. Three specimens have been procured in the neighbourhood of Falmouth, of which W. P. Cocks, Esq. has obligingly sent me information. In Sussex, the Peregrine has been occasionally 
met with inland: sometimes near Petworth, Burton Park, Lewes, Chichester, Arundel, Seaford, Pevensey, Shoreham, and Rye; but seldom on the Weald. Two curious instances of the obtaining of the Peregrine are mentioned by A. E. Knox, Esq.: one was caught in a net, with which a person was catching sparrows from under the eaves of a barn, and the other was shot by a farmer, after it had dashed at a stuffed wood-pigeon, which he had fixed up in a field as a lure to decoy others within shot. I am informed by my friend, the Rev. R. P. Alington, that it is not uncommon in the spring in the neighbourhood of Swinhope, in Lincolnshire. One was shot near there a few years since by Thomas Harneis, Esq., of Hawerby House. Others have been met with in Worcestershire-one in 1849; some on Dartmoor, in Devonshire; and one was caught in a trap at Mutley, in 1831.

In Yorkshire, the Peregrine has had eyries at Kilnsea Cragg and Arncliffe, in Wharfedale, in Craven, as also near Pickering, and on Black Hambleton, the cliffs of the Isle of Wight, and of Devonshire and Cornwall; and it still breeds on Newhaven cliff, and the high cliffs which form Beechy Head, in Sussex. A pair have been in the habit of building there for the last quarter of a century: three young birds were taken from the nest in 1849, and came into the possession of $\mathrm{Mr}$. Thomas Thorncroft, of Brighton, who in his letter to me, describes them as very docile and noble: such they are indeed described to be by all who have kept them. The Bass rock in the Frith of Forth has been another of its breeding-places; as also the neighbourhood of Holyhead; the Great Orme's Head; the rock of Llandedno, in Caernarvonshire; the precipice of Dumbarton Castle; the Isle of May; the Vale of Moffatt, in Durnfriesshire; many of the precipitous rocks of Sutherlandshire; the neighbourhood of Banff and St. Abb's Head; the borders of Selkirkshire, Loch Cor, Loch Ruthven, Knockdolian, in Ayrshire; Ailsa, Ballantrae, and Portpatrick, in Scotland.

In Ireland it has had, according to William Thompson, Esq., of Belfast, many eyries in the cliffs of the four maritime counties of Ulster, as well as some in other parts: in Antrim no fewer than nine, three of them being inland, Glenariff, Salah Braes, and the Cave-hill. So also at Mc. Art's fort, three miles from Belfast, Fairhead and Dunluce Castle, the Horn in Donegal and Knockagh hill, near Carrickfergus, the Gobbins at the northern entrance to Belfast Bay, where two 
pairs built within a mile of each other-a very unusual circumstance. Tory Island, off Donegal, the Mourne mountains in the county of Down, Bray Head in that of Wicklow, the cliffs over the Killeries in Galway, Bay Lough in Tipperary, the Saltee Islands, Wexford, the Blasquet Islands, Kerry, Ardmore and Dunmore in Waterford, and the sea-coast cliffs of the county of Cork.

Whether the Peregrine is partially migratory in this country, seems at present not to have been ascertained. It appears to be thought that the old birds remain about their haunts, while the young ones, after their expulsion from the nest, are compelled to wander about.

Its flight is extremely rapid, and is doubtless well described by Macgillivray, as strongly resembling that of the Rock Pigeon. It seldom soars or sails after the manner of the Eagles and Buzzards. It does so, indeed, occasionally, but its usual mode of flying is near the ground, with quickly repeated beatings of its wings. Montagu has calculated the rate of its flight at as much as one hundred and fifty miles an hour, and Colonel Thornton, at about sixty miles. An average of one hundred may I think be fairly estimated. Meyer says that it never strikes at prey near the ground, through an instinctive fear of being dashed to pieces; but the contrary is the fact, its upward sweep preserving it generally from this danger. The recoil, as it were, of the blow which dashes its victim to the earth, overpowers in itself the attraction of gravity, and it rises most gracefully into the air until it has stayed the impetus of its flight. Instances have however been known where both pursuer and pursued have dashed against trees, or even a stone on the ground, in the ardour of pursuing and being pursued, and each has been either stunned for the time, or killed outright by the violence of the blow. Sometimes, in pursuit of its prey, the Peregrine will 'tower' upwards until both are lost to sight.

The food of the species before us consists principally of birds, such as the larger and smaller sea-gulls, auks, guillemots, puffins, larks, pigeons, ptarmigans, rooks, jackdaws, woodcocks, landrails, wild geese, partridges, plovers, grouse, curlews, ducks, and even at times the kestrel; but it also feeds on hares, rabbits, rats, and other small quadrupeds; as well as at times on larger ones, such as dogs and cats, and also occasionally on fish. It is said to harass the grey crows, but not to use them for food. Instances have been known of Peregrines 
having fallen into the sea, and been drowned, together with birds which they had struck when flying over it; the more remarkable as the prey so seized were only small, and far inferior in size to themselves: probably they had been in some way hampered or clogged, as a good swimmer may be by a drowning boy, so that although if they had fallen on the land, they might have extricated themselves, yet such opportunity has been lost by their mischance of dropping into the sea, and they have met with a watery grave. A black grouse, a bird equal to itself in weight, if not heavier, has been found in the nest of one of these Falcons, with whicls it had probably flown several miles. Sometimes, if it finds a bird which it has struck down too heavy to carry away, it will drop it, and seek another in its stead. It seldom visits the poultry yard. It is said to overpower even the Capercailie. Its clutch is less fatal than its stroke: it has been known to bear away birds for a long distance in its claw, without serious injury.

This bird has frequently been seen to stoop upon and carry off game immediately before sportsmen, both such as had been shot at and killed, and others which were being followed. It takes its prey as well by pursuit, as by a sudden descent upon it. It seldom follows it into cover. Sometimes, for what reason it is impossible to say, it has been known to strike down several birds in suecession, before securing one for its food. One instance however is recorded where having killed, and being in the act of devouring one bird, it chased and caught another of the same kind, still holding the former in one claw, and securing the latter in the other: The Peregrine has been known to cut a snipe in two, and in like manner to strike off the heal of a grouse or pigeon, 'at one fell swoop.' It is said that all the Falcons crush and destroy the head of their prey before devouring them. The Peregrine will occasionally kill and eat the Kestrel, though a bird of its own tribe. In confinement it has been known to do the same; and on one occasion to devour a Merlin, which it had slain. Two instances are recorded also of their killing and eating their partners in captivity. On both occasions the female was the cannibal, but in the latter of the two, she died a few days afterwards, from the effects of the wounds she had received from the male in his self-defence. They soon become quite tame in confinement.

It is very curious how these and all the other birds which 
form the food of the one before us, live in its immediate vicinity, without any apparent fear or dread. They seem patiently to 'bide their time,' and take their chance of being singled out from their fellows. Perhaps with equal wisdom to that of the followers of the Prophet, they are believers in fatalism, and content with the knowledge that whatever is, is, and whatever will be, will be, live a life of security, and resign it at the 'fiat' of the Peregrine, as a matter of course. This applies to cases where both are residents together; where however, strange to say, the Peregrine is only a straggling visitor, his presence but for a day or two has the effect of dispersing the flocks of birds, which had been enjoying themselves before his arrival. Its mode of striking its prey has been variously described. It has by many been supposed to stun its victim by the shock of a blow with its breast, and by others it has been known to rip a furrow in its quarry completely from one end of the back to the other, with its talons or bill. In the former case it is said to wheel about, and return to pick up the quarry it has struck. It is, as may be supposed, the terror of all it pursues, which, rather than venture again on the wing while it is in the neighbourhood, will suffer themselves to be taken by the hand.

In the pursuit of birds near the sea, the Peregrine frequently loses them by their seeking refuge on the water, where they are safe for the time from his attack. If they leave it for the land, they are again pursued, and most interesting chases of this kind have often been witnessed: they end either in the Hawk catching the bird before it can reach the water, or in his being tired out by its perseverance in thus keeping him at bay. Conscious of the disadvantage it is at on this element, it but very rarely indeed attempts to seize prey when upon it: it has, however, been known to carry off a razor-bill or guillemot from a flock in the water, and bear it away to its nest. The mention of this bird may introduce the following anecdote related by Montagu:- 'A writer in a popular periodical describes one pursuing a razor-bill, which, instead of assaulting as usual with the death pounce from the beak, he seized by the head with both his claws, and made towards the land, his prisoner croaking, screaming, and struggling lustily; but being a heavy kird, he so far overbalanced the aggressor, that both descended fast towards the sea, when, just as they touched the water, the Falcon let go his hold and ascended, the razor-bill as instantaneously diving below.' 
A sea-gull has been known to beat a Peregrine in a fair f(I)ight, baffling him by its frequent turnings, in the same way that a white butterfly by its zigzag motions escapes a sparrow.

Feeding as the Hawks do, on birds and animals, they have the habit, partaken of likewise by several other genera of birds, of casting up the indigestible part of their food, which in the present case consists of fur and feathers, in small round or oblong pellets.

The note of the Peregrine is loud and shrill, but it is not often heard except in the beginning of the breeding season.

It builds early in the spring. If one bird is shot, the other is sure to return with a fresh mate. A female bird which had been kept in confinement, has been known to pair with a wild male. She was shot in the act of killing a crow, and the fact was ascertained by a silver ring round her leg, on which the owner's name was engraved. The female while sitting, is heedless of the appearance of an enemy, but the male, who is on the look-out, gives timely notice of any approach, signifying alarm both by his shrill cry and his hurried flight. They defena their young with much spirit, and when the young are first hatched, both birds dash about the nest, in such a case, in manifest dismay, uttering shrieks of anger or distress: at times they sail off to some neighbouring eminence, from whence they descry the violation of their hearth, and again urged by their natural 'storgë,' reapproach their eyrie, too often to the destruction of one or both of them. In either case, however, the situation being a good one, and having been instinctively chosen accordingly, is tenanted anew the following spring, by the one bird with a fresh mate, or by a new pair. In the latter part of autumn, when the young birds' education has been completed, so that they are able to shift and forage for themselves, they are expelled by the old ones from the parental domain. The young are sometimes fed by the one bird dropping prey from a great height in the air to its partner flying about the nest, by whom it is caught as it falls.

The nest, which is flat in shape, is generally built on a projection, or in a crevice of some rocky cliff. It is composed of sticks, sea-weed, hair, and other such materials. Sometimes the bird will appropriate the old nest of some other species, and sometimes be satisfied with a mere hollow in the bare rock. It also builds in lofty trees. 
A simple but ingenious mode of catching the young of these and other Hawks, is mentioned by Charles St. John, Esq., in his entertaining 'Tour in Sutherlandshire.' A cap or 'bonnet' is lowered 'over the horder' of the cliff, down upon the nest; the young birds strike at, and stick their claws into it, and are incontinently hauled up in triumph.

The eggs are two, three, four, or, though but rarely, five in number, and rather inclining to rotundity of form. Their ground colour is light russet red, which is elegantly marbled over with darker shades-patches and streaks of the same. As many as four young have been taken from one nest. When this is the case, one is generally much smaller than the rest. In one instance, however, all four were of equal size; and, moreover, which is still more unusual, and perhaps accounts for the fact thus mentioned, all females-a proportion being generally preserved. Incubation lests three weeks.

The Peregrine varies more in size than perhaps any other bird of prey; sometimes it is nearly equal to the Jer-Falcon. It varies also in colour, but the band on the sides of the throat is a permanent characteristic. Its whole plumage is close and compact; more so than that of any other British species of Hawk. It is a stout and strong-looking bird.

Male; length, from fifteen to eighteen or twenty inches; bill, bluish black at the tip, and pale blue at the base; cere, dull yellowish; iris, dark hazel brown; the feathers between the bill and the eye are of a bristly character; head, bluish black, sometimes greyish black, and sometimes brownish black; neck, bluish black behind, more or less white in front, in some specimens with, and in others without spots: a dark streak from the mouth, often called the moustache, divides it; chin and throat, white or pale buff colour; breast, white, cream white, or rufous white, mottled with spots and streaks; the sides, ash grey, lined lengthways, and barred across with dark brown; back, deep bluish grey or slate colour, shaded off into ash grey, and more or less clearly barred with greyish black some specimens are darker, and others lighter, according to age.

The wings are very long and pointed, extending when closed to within half an inch of the end of the tail: the second quill is the longest, and the first nearly as long, the third a little shorter; greater and lesser wing coverts, bluish grey, barred as the back; primaries and secondaries, dark ash-coloured brown, barred on the inner webs with lighter and darker spots, 
and tipped with dull white; tertiaries, ash colour, faintly barred, greater and lesser under wing coverts, whitish, barred with a dark shade. The tail, slightly rounded, bluish black, or bluish white, tinged with jellowish grey, barred with twelve bars of blackish brown, the last the widest, and the others gradually widening towards it; upper tail coverts, bluish black, barred as the back; under tail coverts, ash grey, barred with dark shades; legs, dull yellow, short and strong, feathered more than half-way down, and scaled all round; the scales in front being the largest; toes, dull yellow, strong and, scaled and rough beneath; the second and fourth are nearly equal, the hind one the shortest, the third the longest, and the third and fourth united by a membrane at the base; claws, brownish black or black, strong, hooked, and acute.

The female is larger by comparison with the male than even is the case with other Hawks. The dark parts of the plumage are darker, and the dark markings larger: they decrease with age. Length, from nineteen to twenty-three inches; cere and iris, as in the male; head, deep greyish brown; neck in front, yellowish white, with longitudinal marks of deep brown, and on the sides and behind greyish brown; the streak on the sides is dark brown; throat, yellowish white, marked longitudinally like the neck; breast, brownish white, or yellowish white, with bars of deep brown: it is altogether more inclined to rufous than in the male, with less grey, the longitudinal spots come higher up, and the transverse spots and bars are broader and more boldly marked, and deeper in hue; back, deep greyish brown, brownish grey, or bluish grey, barred less distinctly than in the male with grey.

The wings, which are of a deep greyish brown colour, or varying as the back, expand to the width of three feet eight or nine inches; the quill feathers are of the same colour, spotted on the outer webs with ash grey, and on the inner ones with cream-colour; greater and Jesser wing coverts, blackish brown, with bars of grey on the outer webs, and spots of reddish white on the inner; secondaries, tipped with whitish. The tail has eighteen bars of ash grey and deep brown alternately; those of the latter colour are the broader: the tip is brownish white; the bars on the tail are more distinct than in the male bird.

The young are at first covered with white down: when fully fledged the bill is dull pale blue, darker at the tip; cere, greenish yellow; iris, dark brown. Forehead and sides of the 
head, yellowish white, or pale rufous; neck behind, yellowish white with dusky spots; chin, yellowish white; throat, white; the band on the side of it blackish brown; breast, reddish white, or pale reddish orange, darkest in the middle, with longitudinal markings of a dark brown colour, and the centre of each feather the same; back, brownish black shaded with grey, the feathers edged with pale brown or rufous. The quill feathers of the wings are blackish brown, spotted with brownish white on the inner webs, and tipped with the same; tail, blackish brown, barred and tipped with brownish red, or reddish white, greyish towards the base; legs and toes, greyish or greenish yellow: as the bird advances towards maturity, a bluish shade becomes observable on all the upper parts, while the lower parts become more white, and the dark marking's smaller, as well as more inclined transversely than longitudinally.

Sir William Jardine describes a variety in a state of change, as having the upper parts of a tint intermediate between yellowish brown and clove brown. The tail, instead of being harred, has an irregular spot on each web of ochraceous, where the pale bands should be, and the longitudinal streakings of the lower parts wood brown, instead of the deep ruddy umber brown seen generally in the young. 


\section{HOBBY.}

Falco subbuteo,

Pennant. Bewick. Seliy.

Falco-To cut with a bill or hook. Subbuteo, a diminutive o: Buteo-A Buzzard.

To my very dear friend, tho Rev. R. P. Alington, of Swirhope Rectory, Lincolnshir $\leadsto$ I am indebted for the original drawing of the bird before us; and many others from the same skilful hand will adorn the pages of the present work, in attitudes cntirely new and striking.

The Hobby is a spirited and daring Hawk, and very detcrmined in pursuit of its game, so that it was formerly much csteemed in falconry, and used accordingly for flying at the smaller birds. It may easily be trained to do so, and becornes very tame when kept in confinement. It has been known to dash through a window into a room, at a bird in a cage; and will occasionally follow sportsmen, and pounce upon the small birds put up by the dogs.

'Though a well-known bird,'Mr. Yarrell correctly says, it is not very numerous as a species.' It is, moreover, from its wild nature, difficult to be approached, and when met with within shot, it is generally when off its guard, in pursuit of its prey.

The Hobby is found thoughout Europe, occurring in Astrachan, Norway, Sweden, Russia, and many other parts of this continent, and is also known in Asia, in Siberia and Indiain the latter widely distributed, and in Africa near the Cape of Good Hope, and no doubt in other districts also. In many parts of England it has not unfrequently occurred. In Yorkshire, principally in the West-Riding, and occasionally near York. It is described by John Hogg, Esq., in a paper communicated by him to the British Association, at its session at York, in the year 1844, and since published in the 'Zoologist,' as being a rare species and migratory in Cleveland. In the East-Riding, one was killed near Knapton by a boy, with a stick: it was at the time in the act of devouring a rook. In Devonshire, it has been accustomed to breed in 




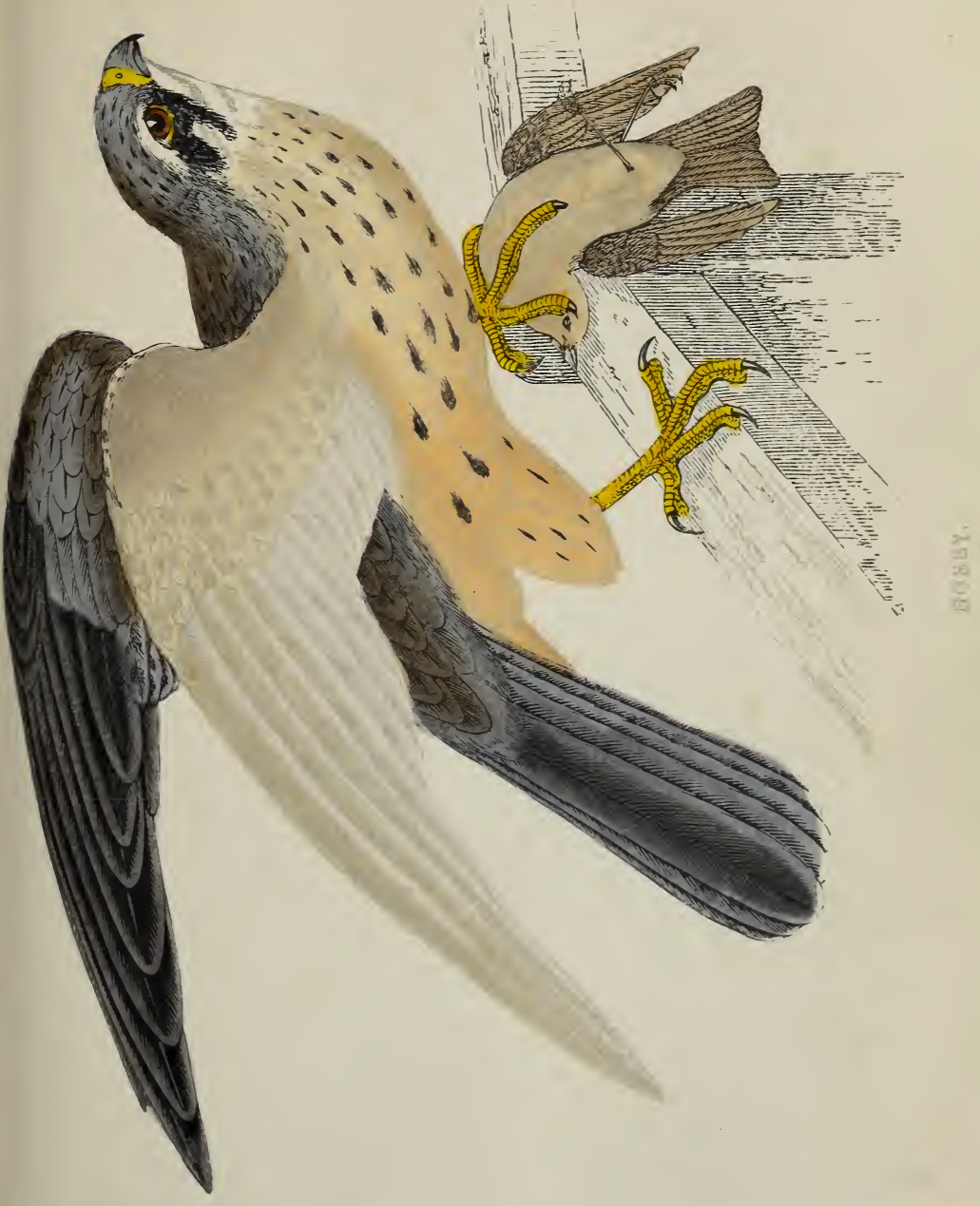



Warleigh woods; in Essex, it has been met ncar Epping; in Norfolk, it occurs as a summer visitor, but the specimens obtained are, according to John H. Gurney, Esq. and Williarn R. Fisher, Esq., in their Catalogue of the Birds of Norfolk, published in the 'Zoologist,' far from numerous, and generally in immature plumage. The same gentlemen record that it occasionally breeds in that county, and that an instance of its doing so occurred at Brixley, near Norwich, in the spring, of 1844; and they mention that an immature specimen of the Hobby was shot some years since while sitting on a church tower, in the centre of the city of Norwich. The occurrence of this species at Yarmouth, so early as the month of February, is noticed at page 248 of the 'Zoologist.' It has once been mct with in Durham. In the Isle of Wight it is, says the Rev. C. Bury, in his Catalogue of the Birds of that island, occasionally seen, but he adds that he has not been able to ascertai that it has been known to breed there. An adult male was shot in the land-slip, in October, 1841; and a pair were killed some years previous, also in the autumn, in the heart of the island. In Kent it is recorded by J. Pemberton Bartlett, Esq., to be not uncommon. In Sussex, it has occurred near Battle, Pevensey, Lewes, and Halnaker, in September, 1836, and in other parts of that county. It is sufficiently common, according to the Rev. R. P. Alington, in the neighbourhood of Swinhope, Lincolnshire; as it also has been in Derbyshire, Oxfordshire, Lancashire, Dorsetshire, where it has been known to breed; as likewise at Cottenham, in Cambridgeshire. Cumberland as yet would seem to be its northernmost range. It does not appear to be known in Scotland.

'Unlike the Peregrine,' says A. E. Knox, Esq., 'it prefers the wooded district of the weald to the downs or the open country near the coast, being there a summer visitor. Yet, even in these his favourite haunts, he must be considered scarce, and you will rarely discover his decaying form among the rows of defunct Hawlss which garnish the gable end of the lieeper's cottage-a sort of ornithological register, which would appear to indicate, with tolerable accuracy, the prevalence or scarcity of any species of raptorial bird in its immediate neighbourhood.'

"The courage and address of this Hawk are remarkable. When shooting with a friend a few years ago, during the early part of September, we observed a Hobby pursuing a partidge, which, having been wounded, was then in the act 
of 'towering.' The little fellow proved himself to be a true Falcon, by the quickness with which he rose above his quarry in rapid circles, 'climbing to the mountee,' as our ancestors termed this mancuvre, with all the ease of a Peregrine. Unfortunately, at this juncture the partridge became suddenly lifeless, as is the case with all towering birds, and fell to the ground; while the Hobby, apparently disdaining to accept a victim which he had not obtained by his own exertions, scudded away after a fresh covey.'

In Ireland, it is the opinion, much to be depended on, of William Thompson, Esq., of Belfast, that the few individuals of the Hobby recorded in former years as having occurred, have been males of the Peregrine. He gives only one specimen as having indubitably been met, which was shot on his garden wall by - Parker, Esq., of Carrigrohan, about three or four miles from Cork, up the beautiful River Lee. It by no means affects only the wilder districts, but is to be seen in such as are best cultivated, preferring, of course, those in which wood is plentiful.

It is said that the Hobby is in this country a summer visitor, appearing in April, and departing towards the end of October, or beginning of November. It has however been seen in the month of December, in the pursuit of its game, so that it would appear, at all events, not to be universally a migratory bird, at least from this country; it may besides make partial migrations from one locality to another, as pleasure or necessity happens to direct. It has been kept throughout the winter without any difficulty, by the Revs. A. and $\mathrm{H}$. Natthews. It flies, like others of its tribe, till late in the evening, in pursuit of insects or other food.

The flight of this species is extremely rapid and easy, performed with little motion of the wings, and it continues for a long time together on the wing. It will sometimes 'tower' upwards in the most spirited manner in pursuit of its prey. Its food consists of small birds, such as snipes, plovers, swallows, sandpipers, quails, and thrushes, and it would appear to be particularly partial to larks and buntings. It will even fly at the partridge, though a bird of so much greater bulk than itself. It also feeds on the larger coleopterous insects, such as cockchaffers, and on grasshoppers; the former it sometimes hawks after over ponds and streams until late in the evening. The male and female are said, according to Meyer, to lint together, but sometimes to quarrel for what 
they have caught, and so to suffer their prey to escape from them. The note is said to resemble that of the Wryneck.

The Hobby builds in the trees of woods and forests, generally among the topmost branches, but sometimes in a hole of a tree. In the former case, a preference is given to isolated fir or other plantations, as affording at the same time a less likelihood of disturbance, a better view of approach from all sides, and a supply of the several kinds of food on which the bird lives. It has also been known to build on the ledges of steep precipices or mountains. The same pair will return to their breeding place from year to year if not disturbed. The nest is built of sticks, and is lined with moss, hair, and other such materials. Occasionally the forsaken tenement of some other species of bird is made to serve the purpose of one of its own fabrication. It frequently avails itself of that of the carrion crow, or a magpie.

The eggs, which are laid about the first week in June, are two, three, or four in number; some say that the former, and others that the latter is the more frequont amounts: they are of a rather short and oval shape, and of a dingy white, or bluish white ground colour, much speckled all over with reddish or yellowish brown, or sometimes with olive green. Mr. Hewitson says that they are very much like some of those of the Kestrel, as well as those of the Merlin, but that they are larger than either; of a pinker hue, less suffused with colour, and marked with fewer of the small black dots which are scattered over the surface of the others. The young remain for some time in the neighbourhood of the nest, until they have gradually learned to cater for themselves.

In general appearance, the Hobby resembles in some degree the Peregrine, at least on the back, for the breast is streaked instead of barred. It is also of a more slender shape-the wings are longer than the tail.

Male; upper parts of a general dark slate-colour, the shafts of the feathers being darker; the lower parts yellowish or rufous white, streaked with dark-brown; weight about seven ounces or half a pound; length, about one foot or thirteen inches; bill, black or bluish black, darkest at the tip, blue at the base; cere, yellow; iris, reddish brown or orange. The head large, broad, and flat, of a dark slate-colour; crown, greyish black; neck, white on the sides, and brownish white or ferruginous on the middle part behind, a black streak or band running downwards from the angle of the bill; nape, 
greyish black; chin and throat, white; breast, yellowish white, streaked with brown; back, dark slate-colour. The wings, which expand to about two feet two inches, have the quills dusky black, with yellowish brown or ferruginous oval spots on the inner webs - the second quill is the longest in the wing; greater and lesser wing coverts, dark slate-colour. The tail, which consists of twelve feathers, and is as much as six inches long, and slightly rounded at the end, is dark brownish grey, the two middle feathers plain, the others transversely marked with reddish white or yellowish brown; under tail coverts, bright orange red or ferruginous, with dusky streaks. The legs short, and feathered about a third down, the feathers on them deep rufous, and streaked like the under tail coverts, but in extreme age these markings are said to wear off, and the ground colour alone to remain. The toes reticulated, and united at the base with short webs.

Female; weight, about nine ounces or upwards; length, thirteen or fourteen inches; bill, the same as in the male. The feathers of the head are margined with brown, which probably wears off with age; neck, white on the sides, brownish white or light ferruginous on the middle part behind; the band blackish brown; throat, white; back, greyish brown, the shafts being of a darker hue; breast, reddish white, streaked with dark brown. The wings expand to about two feet four inches; the quills are brownish black, spotted on the inner webs with reddish white. The tail greyish brown, faintly barred with a darker shade; under tail coverts, light yellowish red.

The young bird has the cere greenish yellow, of a very light shade, at first almost white; iris, dark brown or dusky; front of the head, yellowish grey, with a line of the same over the eyes; crown of the head and nape, greyish black; the feathers edged with yellowish white. The neck white on the sides, and surrounded by a ring of yellowish white, which is indistinct behind, the band black; chin, white; throat, yellowish white; breast, yellowish white, streaked with brownish black; back, greyish black, edged with dull white; quills of the wings as in the old birds; greater and lesser wing coverts, greyish black; primaries and secondaries, nearly black, edged with dull white. The tail as in the female, but the bands are light red; the tip and the quills, reddish white; beneath, it is barred with dull white and greyish black; lower tail coverts, yellowish white with brown shafts. The legs yellow; feathers of the legs, yellowish white, with oblong brown spots; claws, black. 




\section{ORANGE-LEGGED HOBBY.}

Falco rufipes,

Falco vespertinus,
Bechstein.

Grelin. Linjeus. Latham.

Falco-To cut with a bill or hook. Pes-A foot.

Rufipes. Rufus-Red.

There is not much at present to be said about the species before us, and it is so far well, in that it allows the greater space to treat of other more common, and therefore better known, British Birds. In a work of this kind, it is, for the most part, room and not matter that is wanting; 'brevis esse laboro,' and it is a matter of regret that I am obliged to do so, but a necessarily short article in the one case leaves the more scope for a longer one in another.

The Orange-legged Hobby, delighting in a mountainous and at the same time wooded region, is common in some parts of Europe, but rare in others. It is plentiful in Russia, Silesia, Hungary, Poland, and Austria; less so in Italy, Switzerland, and the Tyrol; uncommon in France, and unknown in Holland.

But very few examples of British specimens of this species have as yet been obtained. In Yorkshire, a male has been recorded by J. S. Foljambe, Esq., to have been obtained some years since; another is said to have been shot at Rossington, near Doncaster; a third was killed a few years ago near Easingwold, and was sent to Mr. H. Chapman, of York, to be preserved, with a message that if it was a cuckoo, he was to stuff it for the person who shot it; but that if it was not a cuckoo, he might, if he stuffed it, keep it for his pains. A fourth was shot on the 6th. of May, 1S-, at Stainor Wood, near Selby. Three were obtained together in the month of May, in the year 1830, at Horning, in the county of Norfolk, an adult male, a young male in immature plumage, and an adult female. A fourth specimen, a female, was also shot in Holkham Park, the seat of Mr. Coke, (Lord Leicester;)

VOL. I. 
a fifth in the same county, in the year 1832; and a sixth, a male in adult plumage, in August, 1843, near Norwichits stomach contained only beetles. Two have been procured, both males, near Plymouth, as I am informed by Mr. R. A. Julian, of that place. The first he says flew on board a vessel in the Channel near the Breakwater, and was captured; the other was brought to Mr. Pincombe, bird preserver of that town, by a person who shot it at Wembury cliff, and who said that he saw another of the same lind in company with it. One has been obtained in the county of Durham. In Scotland it has hitherto been unknown. In Ireland one, (and possibly another, but it is uncertain,) was procured in the county of Wicklow, in the summer of 1832. It was shot just as it had pounced on a pigeon, of at least its own size, in a gentleman's yard-both fell dead at the same discharge.

Mr. Meyer says-'I have more than once seen this bird, but have not been so fortunate as to obtain it. On one occasion, in the summer of 1838, I was late one evening walking in the unenclosed plantations belonging to Claremont, on a heath on which I knew they were sometimes found, when my advance roused from the ground a bird, whose peculiar flight instantly arrested my attention, and I followed it as far as the enclosure of the plantation into which it had entered would permit; I presently perceived it sitting upon the branch of a tree, in company with another bird of similar size, but differing in colour. I was near enough to observe their plumage, and no doubt remained upon my mind respecting them-they were Orange-legged Hobbies.'

The food of this species consists of the smaller birds, such as quails, and even occasionally those that are much larger, as the pigeon just mentioned, and the larger coleopterous and other insects. In pursuit of the latter it is seen skimming over watery places until late in the evening - a habit also of others of the Hawks-uttering its note from time to time. One of its specific names, 'vespertinus,' (of, or belonging to the evening,) is doubtless hence derived.

Its nest is said to be built in the hollows of trees, and it is also stated that use is sometimes made of that of a magpie or other bird.

Male; after the first moult the whole plumage of the back is more uniforn than in the female. The general colour is deep leaden blue except the legs and under tail coverts, which are bright yellowish red. Length, about eleven inches; bill, 
yellowish white at the base, the rest horn colour, inclining to yellowish brown towards the tip; cere, reddish orange; iris, dark brown; head, crown, neck, nape, chin, throat, breast, and back, dull lead colour. The wings, which reach all but to the end of the tail, are of a dull lead colour, the quills lighter with brownish black shafts; the second feather is the longest in the wing, being about half an inch longer than the first and third, which are of an equal length. Greater and lesser wing coverts, primaries, secondaries, and tertiaries, of the same dull leaden hue; tail, dull lead colour; tail coverts the same; under tail coverts, deep ferruginous; legs, which are feathered in front more than one third down with deep orange ferruginous, and the toes, light reddish. The claws, yellowish white with dusky tips. It seems possible that the white colour may be the result of age.

The female, on the upper parts of the body is of a general greyish blue barred with black; the head and back of the neck, yellowish red; the lower parts light yellowish red with longitudinal brown spots. When old, the plumage is said to become lighter in colour, and the black bars narrower. Length, about twelve inches; bill and iris, yellow; forehead, whitish; crown, pale rufous; neck, on the back part, and nape, dark reddish brown or yellowish red, as is also the moustache, sometimes approaching to black. The neck behind is barred with greyish black. The chin and throat nearly white, having a slight reddish or yellowish tint; breast, pale rufous brown, tinged with cinereous, $\cdot$ with dark reddish brown longitudinal streaks; the shafts of the feathers and a spot near the tip, dark brown. These marks are said to disappear with age. The back, greater and lesser wing coverts, blackish grey or bluish grey, transversely barred on each feather with bluish or greyish black; the quills blackish grey on the outer webs and tips, and transversely barred with white on the inner; under wing coverts, rufous with transverse bars of dark brown; primaries, secondaries, and tertiaries, dusky black. The tail on the upper surface, as also the tail coverts, blackish grey or bluish grey, transversely barred with bluish black; on the lower surface it is bluish grey, with nine or ten bars of bluish black, shewn through from above, the bars gradually wider in the direction of the tip; under tail coverts, light yellowish orange, (Meyer says white,) as are the feathers on the legs. The legs and toes deep orange yellow; claws, as in the male. The young male is at first similar in plumage to the young 
female, but at the first moult it assumes a general bluish grey colour, the feathers on the legs being ferruginous; the bill, cere, legs, toes, and claws, are like those of the old bird.

The young female has the bill, cere, and iris as in the adult; arown of the head, reddish brown with dusky streaks, the feathers tipped with light red-a small moustache descends from the front of the eye; neck on the sides, pale reddish or yellowish white, with longitudinal brown streaks and blots. The throat white; breast, as the sides of the neck; back, dark brown, the feathers being tipped with reddish brown. Wing coverts, the same; primaries, secondaries, and tertiaries, dusky black, the inner edges and the tips being buff white. The tail dark brown, crossed with numerous bars of reddish brown; under tail covertis, deep ferruginous; legs, toes, and claws, as in the adult. 



$$
\text { f }
$$






\section{MERLIN.}

Falco asalon,

Pennant, Montagu. Bewick. Fleming.

Falco-To cut with a bill or hook. Asalon-A species of Hawk, (Aristotle,) supposed to be the Merlin, or the Sparrow-Hawk.

THOUGH an Eagle, by comparison with some of the East Indian species of Hawks, the Merlin is the smallest that occurs in this country. In spirit it is 'nulli secundus,' inferior to none, and was accordingly used in former times in falconry for the pursuit of birds even much larger than itself, which it would frequently kill by a single blow on the head, neck, or breast. The author of the 'Book of Falconrie'-says that they were 'passing good Hawks, and very skilful.' Unlike the Sparrow-Hawk and the Kestrel, if pursued by swallows and other small birds, it has been known, instead of flying from them, to become in its turn the aggressor, and at once disperse them. Like the Hobby, it has been captured by its dashing through a pane in the window of a cottage, in pursuit of a yellow-hammer.

This species appears to claim citizenship in all the four quarters of the globe. In Europe it is known in Denmark, Norway, Sweden, Germany, and France; in North America, in Asia Minor, and in Africa as far south as the Cape of Good Hope. It is more frequently met with in the northern, than in the southern parts of England, though in neither can it be said to be common. The former are its breeding districts. In Yorkshire, it has very frequently occurred, especially in the West-Riding: occasionally in Derbyshire.

In Sussex, it has been repeatedly noticed in the wilder and less cultivated districts. In Berkshire, I once myself shot one, now many years ago. It was a beautiful female, flying up a brook down by which I was walking-an unfortunate 'rencontre' for it - and fell, apparently quite dead, as indeed it proved to have been; but so remarkable was the similarity 
of its plumage to the stones on which it had fallen at the side of the stream-a novel appropriation of its name of Stone Falcon-that I the less wondered at having before almost given up searching for it, and gone away with the belief' that it had not been killed, but only wounded, and had run into some cover, than at finding it when I did. It is considered rare in Cornwall, (one was shot there in 1849, November 9th., near Falmouth, and one near Penryn,) Devonshire, Dorsetshire, Kent, one at Dodington, in 1840, Essex. and Norfolk.

It breeds in Northumberland, Westmoreland, and Cumberland. It is uncommonly met with in the neighbourhood of Swinhope, Lincolnshire. The Rev. Leonard Jenyns mentions one recorded by Graves, as having been killed in Cambridgeshire. In Aberdeenshire, and other parts of Scotland, and in the Orkney and Shetland Islands, it also breeds. In Ireland it is indigenous, both in the northern and southern parts, throughout the whole of the year, but would seem to be somewhat locally migratory. It breeds on the mountains of the counties of Londonderry, Tyrone, and Down, as also in those of Waterford, Cork, Tipperary, and Kerry. In Wales, it breeds on Cader Idris, and in other parts.

The Merlin is partially migratory in this country, being for the most part a constant resident in Scotland and the northern parts of England, but appearing to be only a winter visitant in the south. It has however, on one occasion, been known to breed in the county of Suffolk, and probably may have been overlooked in more frequent instances of the same kind in those wilder districts, such as Dartmoor, which are suitable to it.

From a habit it has of perching on stones, it has acquired the name of the Stone Falcon, and as such was formerly described as a distinct species. It must have a fondness for the practice, for it carries it out even on those rocks which are left partially prominent by the receding tide, when hawking, as it sometimes does, on the margin of the sea.

It is a very courageous bird-wild and shy, and according to Temminck, is able to endure a high degree of cold, and is described by him as being commonly found within the limits of the arctic circle. It is easily tamed, though it never becomes very familiar, and was accordingly in former times employed in the chase. Except when the young are hatched, it is difficult, or account of its wariness, to lie 
approached; it is only by accident that it is occasionally met with within gun-shot.

The Merlin flies low, and with great ease and celerity. It suddenly sweeps by, and is gone almost before you have had time to glance at it, gliding along the side of a hedge or wood, and then over, or into it, and sonetimes affording a more lengthened view, by its flight over the open fields, or the wide moor, where it may be seen following its prey through its devious track, according to the nature of the ground. 'In pursuit of prey,' says Sir William Jardine, 'the Merlin does not often mount above it and rush down, as we have generally seen the Peregrine, but at once gives chase, following the victim through all its turns and windings to escape, and unless cover is at hand, is generally successful.'

Its principal food consists of birds; and it attacks and slays those which are even double its own size, such as partridges, and also quails, plovers, and pigeons, as well as larks, linnets, starlings, sandpipers, snipes, chaffinches, blackbirds, swallows, thrushes, goldfinches, and others which are smaller; as also cockchaffers and other insects. In pursuit of shore birds, dunlins, ring dotterels, and others, it will course them to the edge of, and sometimes even over the water. It is so determined on and in the capture of its prey, that it is difficult to make it leave that which it has secured, and which it often obtains by pouncing on it unawares, but it also chases it in the open air. The lesser birds it captures from the ground, but those which are too large to be thus borne off; it can only surprise when on the wing. It frequently perches on a stone or crag, flitting from one to another, as if for the purpose of surveying all around it, and when a flock of small birds comes within its ken, it singles out one from the rest, and is not attracted from it to any of the others.

The nest is generally, in this country at least, built on the ground on open moors or heaths, frequently on the side of a ravine, in a tuft of heath or projection of a rock or bank, and when this is the case, is composed of very scanty materials -a few sticks, with heather, grass, or moss - the bare ground almost sufficing for the purpose. In other countries it appears, occasionally at all events, to be built in trees, and is then made of sticks, and lined with wool. In the Orkney and Shetland Islands, it is placed among precipitous and inaccessible rocks.

'The eggs are three, four, or five, in number; Bewick say: 
six; and Temminck five or six. They are bluish white, blotted, particularly at the thicker end, with deep reddish brown or greenish brown. They vary, however, much in colour. Some of the varieties are often similar to those of the Kestrel or Peregrine, others to those of the Sparrow-Hawk, but still more to those of the Hobby. They are of course, however, rather smaller than the former, and also, in this variety, browner in colour and more closely spotted with small dots. One has been obtained of a rich crimson red, blotted with a darker shade of the same. The female sits close at first, but if disturbed or alarmed more than once, becomes extremely shy. The male takes up a position near at hand on the top of some eminence, from whence he can perceive the approach of any intruder, of which he gives notice by shrill cries of alarm. Montagu says that an instance has been known of a Merlin building in a deserted crow's nest.

Male; upper parts deep greyish blue, each feather having a black central line; the lower parts dull ruddy yellow, with longitudinal dark brown oblong spots. Weight, from five to six ounces. Length, from eleven inches to a foot, or twelve inches and a half; (one described by Montagu was only ten inches long.) The male and female differ generally but little in size, compared with others of the Hawks. Bill, short, strong, pale blue at the base, blackish blue at the tip; cere, dull yellow; iris, dark brown; (one shot at Osberton, and described by J. S. Foljambe, Esq., had the iris yellow.) Head, large, broad, and flat; forehead and sides of the head, greyish white-the latter lined with black. There is a greyish white band over the eye, margined beneath with black. Crown, dark bluish or brownish grey, each feather streaked with black in the centre. Neck, short and thick-set, dull yellowish red, encircled with a reddish brown ring, spotted or streaked with black. From the corners of the mouth descend on each side a few black streaks, forming, though faintly, the moustache borne by all the true Falcons. Nape, banded with pale red; chin, white; throat, white, or greyish, or buff white; breast, dull yellowish red, sometimes deep orange brown; the shafts and a spot towards the end, dark brown. Back, deep greyish blue, lighter towards the tail-the feathers streaked in the centre with black, as are all the other bluish feathers of the back.

The wings, which when closed, reach from within an inch and a quarter to two inches of the end of the tail, and expand 
to about two feet four inches, have the primaries black, or blackish or bluish brown, tinged with grey - the outer margin of the first spotted with white, the inner webs spotted transversely with white; underneath they are of a paler colour, barred with white: the third feather is the longest, but the second is nearly as long; the fourth a little longer than the first; the fifth an inch shorter; secondaries, deep greyish blue, and curved inwards-the shafts black; tertiaries also greyish blue. Greater and lesser wing coverts, bluish grey-the shafts of the feathers black; greater and lesser under wing coverts, yellowish white, with dusky spots and streaks. The tail bluish grey; it generally has, but is sometimes without, from even only one, but commonly from three or five to six, and, according to Pennant, eight, and even thirteen dark bands; viz:- in the proportion of six on the middle feathers, to eight (probably age is the cause of the gradual difference in their number,) on the side ones, but which merge apparently into the smaller-named number-the last being the largest and darkest. The tail is five inches long; the feathers are twelve in number, being of nearly equal length, broad, and rounded: the tip is white, underneath it is barred with darker and lighter shades of grey, with the broad band and white tip. Legs, yellow, feathered in front more than one third down, and reticulated. The feathers are rufous, with dusky streaks; toes, yellow; the first the shortest; the third the longest; the fourth a little longer than the second: the front ones are connected at the base by a short membrane; claws, black.

The female differs considerably from the male; upper parts dark bluish grey, tinged with brown-the feathers streaked with black; under parts yellowish white, with large brown spots. Weight, about nine ounces; length, about twelve inches and a half, occasionally as much as thirteen and a half or fourteen inches; bill, light blue, tipped with black. From the angle of the mouth extends a band of brown, formed by the markings on the middle of the feathers; cere, yellow; iris, as in the male; forehead, yellowish white; a yellowish line edged on the under side with blackish brown, extends over the eye; head, dark rufous brown, the feathers edged at the tip with red; crown, reddish brown, with dusky black streaks down the shafts of the feathers; neck, behind yellowish white, the feathers tipped with brown: there is a ring round it of yellowish white, streaked and spotted with dusky brown. The nape, inclining to rufous, and as the crown; chin and throat, white or yel- 
lowish white, the feathers on the side being tipped with brown; breast, pale reddish yellow, or brownish or yellowish white, marked with many oblong spots of dark brown, larger than those of the male; back and wings, brown mixed with rufous, the shaft and centre of each feather being darker, and the edge tipped with red; greater wing coverts, brown, edged with dull yellowish white or light rufous, the centre of the feathers being grey; lesser wing coverts, greyish brown, bordered with rufous, the shafts being black. Primaries, secondaries, and tertiaries, brownish black, spotted with light red spots on both the webs, and edged with red, the tips the same colour of a paler shade. Greater and lesser under wing coverts, brownish red, spotted and edged with yellowish white; tail coverts the same, edged the same. The tail, which is greyish brown, or dusky, has five bars of very pale reddish brown or yellowish white spots, and the tip banded with greyish white; the side feathers have two light bars at the base; upper tail coverts, brown, edged with dull yellowish white; under tail coverts, white, with the exception of the feathers on the sides, which have each a line of brown. Legs, yellow, the long feathers streaked with brown; the shorter ones nearly white; toes, yellow; claws, black.

The young birds when fully fledged, most resemble the adult female, but are lighter in colour; the males however less so than the females, and tinged with blue on the back. The former gradually assume more blue, but the latter change less. The centre of the feathers in the immature birds is dark brown edged with rufous, instead of being marked in the centre with grey. Bill, as in the adults; cere, dull yellow. A yellowish line extends over the eye; iris, brown, but subject to variations of shade, according to Selby; forehead, yellowish white; head streaked on the sides, which are yellowish red, with brown, and a band of the latter colour descends from the angle of the mouth; neck, yellowish behind, the feathers tipped with brown; chin, yellowish white; throat, yellowish white, the shafts of the feathers brown; breast, pale reddish yellow, streaked longitudinally with brown; back, dark brown, slightly tinged with blue, the feathers edged and marked with pale yellowish red in obscure spots, and streaked in the centre with dark brown or black; greater wing coverts, spotted with light reddish spots, and tipped with the same; primaries, very dark brown, indistinctly spotted on the outer webs with pale yellowish red, and tipped with the same, but paler; secondaries, 
spotted in the same manner on both webs; tail, dark brown, barred with five distinct bands composed of pale reddish brown spots; the tip is reddish or greyish white: there are three other bars near the base; under tail coverts, partially streaked with a narrow brown line near the end; legs, dull yellow, the feathers marked with a brown streak.

The males vary in colour as they advance in age, the blue on the back being tinged with brown at first, and becoming gradually of a purer hue. In some specimens also the breast is of a light yellowish red, and in others deep orange brown. In some the tail is without the dark bands, except the last and broadest one; and in others the middle feathers are without them, while they are apparent on the rest.

The females differ less than the males, but assume more of the character of the plumage of the latter, especially on the upper parts, as they advance in age. 


\section{KESTREL.}

WINDHOVER. STONEGALL. STANNEL HAWE.

Falco Tinnunculus, Accipiter alaudarius,
Montagu. Selby. BRISSON.

Falco Tinnunculus.

Falco-To cut with a bill or hook Tinnunculus-Conjectured from Tinnio-To chirp.

THIs species is in my opinion, not only, as it is usually described to be, one of the commonest, but the commonest of the British species of Hawks. It is found in all parts of Europe-Denmark, France, Italy, Spain, Norway, Sweden, Lapland, Greece, and Switzerland; and also in Asia, in Siberia; in Central Africa, and at the Cape of Good Hope; and also, according to Meyer, in America. It is easily reclaimed, and was taught to capture larks, snipes, and young partridges. It becomes very familiar when tamed, and will live on terms of perfect amity with other small birds, its companions. It formed, and perhaps still forms, one of the so-called 'happy family,' to be seen, or which was lately to be seen, in London. The Kestrel has frequently been taken by its pursuing small birds into a room or building. It does infinitely more good than harm, if indeed it does any harm at all, and its stolid destruction by gamekeepers and others, is much to be lamented, and should be deprecated by all who are able to interfere for the preservation of a bird which is an ornament to the country.

These birds appear to be of a pugnacious disposition, J. W. G. Spicer, Esq., of Esher Place, Surrey, writing in the 'Zoologist,' pages 654-5, says, 'all of a sudden, from two trees near me, and about fifty yards apart, two Hawks rushed simultaneously at each other, and began fighting most furiously, screaming and tumbling over and over in the air. I fired and shot them both, and they were so firmly grappled together by their talons, that I could hardly separate them, though 


dead. They were both hen Kestrels. What could have been the sudden cause of their rage? It was autumn, and therefore they had no nests.' In the next article, the following is recorded by Mr. W. Peachey, of Northchapel, near Petworth: - A few weeks ago, a man passing a tree, heard a screaming from a nest at the top. Having climbed the tree and put his hand into the nest, he seized a bird which proved to be a Kestrel; and at the same instant a Magpie flew out on the other side. The Kestrel, it appears, had the advantage in being uppermost, and would probably have vanquished his adversary, had he not been thus unexpectedly taken.' Two instances are related by the late Frederick Holme, Esq., of Corpus Christi College, Oxford, the one of a male Kestrel having eaten the body of its partner, which had been shot, and hung in the branch of a tree-'a piece of conjugal cannibalism, somewhat at variance with the proverb, that 'hawks don't poke out hawks' een;' and the other as a set off, he says of 'six of one, and half-a-dozen of the other,' a pair of Kestrels in confinement having been left without their supper, the male was killed and eaten by the female before morning.'

In Yorkshire, the Kestrel is a common bird, as in most parts of England. In Cornwall it appears to be rare. One, a male, was shot, Mr. Cocks has informed me, at Trevissom, in January, 1850, by Master Reed; and others at Penzance and Swanpool, in 1846. In Scotland it is likewise generally distributed. In Ireland it is also common throughout the island.

The debateable point respecting the natural history of the Kestrel, is whether it is migratory or not. Much has been written on both sides of this 'vexata quæstio;' and as much, or more, one may take upon oneself to say, will yet be written on the subject. My own opinion is against the idea of any migration of the bird beyond the bounds of this country. Stress has been laid, in an argument in favour of such a supposed movement, on the fact of the departure of the broods of young Kestrels from the scene of their birth. But who could expect them to remain in any one confined locality? Brood upon brood would thus accumulate, in even more than what Mr. Thornhill, in the 'Vicar of Wakefield,' calls a 'reciprocal duplicate ratio;' a 'concatenation of self-existences,' which would doubtless soon find a lack of the means of subsistence in a neighbourhood calculated probably to afford sufficient food for only a few pairs. Unless in the case of the Osprey, which must 
be admitted from the nature of its prey, brought together in vast profusion at the same period of time, to be an exceptional one. I am not aware of any Hawks which build in company in the same way that rooks do: and $I$ have never yet heard of a Kestrelry. The fact of the dispersion of the young burds is nothing more than might, from the nature of their habit of life, be looked for. Their very parents may expel them, as is the case with other birds of the same tribe. They have come together from roaming over the face of the country, to some situation suitable for them to build in, and a like dispersion of their offspring is the natural course of things.

As to any total, or almost total disappearance of the species in winter, it is most certainly not the general fact, whatever may appear to be the case in any particular locality or localities. The only one I ever shot, the brightest coloured specimen, by the way, I ever saw, was in the depth of winter, and it fell on the same day as did the Merlin which I have spoken of, as having had the misfortune to come across my path, upon snow-covered ground, with its beautiful wings stretched out, for the last time, poor bird. In the parts of Yorkshire in which I have lived, the county with reference to which the observations I have alluded to have been made, and I have lived in all three Ridings, though my assertion at present applies to the East only, I have never observed any diminution in the number of Kestrels that are seen in the winter, from those which are to be seen in summer, hovering over the open fields. It would seem very possible, from the different observations that have been made, that they may make some partial migrations in quest of a better supply of food.

Still after what I have said, I must not be understood as unhesitatingly asserting that none of our British born and bred Kestrels cross the sea to foreign parts. It would be presumptuous in any one to hazard such an assertion: in this, as in most other supposed matters of fact, our ignorance leaves but too abundant room for difference of opinion. "There be three things,' says Solomon, 'which are too wonderful for :me, yea, four which I know not;' and one of these he declares to be the way of an Eagle in the air.' We need not be ashamed of keeping company with him in a candid confession of our own shortsightedness.

Since writing the above, I find that Mr. Macgillivray remarks that in the districts bordering on the Frith of Forth, 
these birds are more numerous in the winter than in the sunmer, and he adds that probably 'like the Merlin, this species merely migrates from the interior to the coast.' And 'in the north of Ireland, generally,' says Mr. Thompson, 'Kestrels seem to be quite as numerous in winter as in summer, in their usual haunts.'

The Kestrel begins to feed at a very early hour of the morning. It has been known to do so even almost before it was light. Several others of this family, as I have before had occasion to observe, continue the pursuit of their prey until a correspondingly late hour in the evening.

Other species of Hawk may be seen hovering in a fixed position in the air, for a brief space, the Common Buzzard for instance, but most certainly the action, as performed by the Kestrel, is both peculiar to and characteristic of itself alone, in this kingdom at least. No one who has lived in the country can have failed to have often seen it suspended in the air, fixed, as it were, to one spot, supported by its out-spread tail, and by a quivering play of the wings, more or less perceptible.

It has been asserted that the Kestrel never hovers at a greater height from the ground than forty feet, but this is altogether a mistake. The rery last specimen that I hare seen thus poised, which was about a fortnight since, in Worcestershire, seemed to me as near as I could calculate its altitude, to be at an elevation of a hundred yards from the ground. I mean, of course, at its first balancing itself, for down, as the species is so often seen to do, it presently stooped, and then halted again, like Mahomet's coffin, between sky and earth, then downwards again it settled, and then yet once again, and then glided off-the prey it had aimed at having probably gone under corer of some sort: otherwise it would have dropped at last like a stone upon it, if an animal very probably fascinated, and borne it off immediately for its meal. It is a bird of considerable powers of flight. Tame Kestrels kept by Mr. John Atkinson, of Leeds, having had their wings cut to prevent their escape, exhibited, he says, great adroitness in climbing trees.

The food of the Kestrel consists of the smaller animals, such as field mice, and the larger insects, such as grasshoppers, beetles, and caterpillars: occasionally it will seize and destroy a wounded partridge, but when seen hovering over the fields in the peculiar and elegant manner so well illustrated by my 
friend the Rev. R. P. Alington, in the engraving which is the accompaniment of this description, and from which the bird derives one of its vernacular names, it is, for the most part, about to drop upon an insect. Small birds, such as sparrows, larks, chaffinches, blackbirds, linnets, and goldfinches, frequently form part of its food, but one in confinement, while it would eat any of these, invariably refused thrushes. The larvæ of water insects have also been known to have been fed on by them, and in one instance a leveret or rabbit, and in another a rat. Slow-worms, frogs, and lizards are often articles of their food, as also earth-worms, and A. E. Knox, Esq. possesses one shot in Sussex, in the act of killing a large adder. Another has been seen devouring a crab, and another, a tame one, the result doubtless of its education, as man has been defined to be 'a cooking animal,' a hot roasted pigeon. 'De gustibus non disputandum.'

'The Kestrel,' says the late Bishop Stanley, 'has been known to dart upon a weasel, an animal nearly its equal in size and weight, and actually mount aloft with it. As in the case of the Eagle, it suffered for its temerity, for it had not proceeded far when both were observed to fall from a considerable height. 'The weasel ran off unhurt, but the Kestrel was found to have been killed by a bite in the throat.' $\mathrm{He}$ adds also, 'not long ago some boys observed a Hawk flying after a Jay, which on reaching, it immediately attacked, and both fell on a stubble field, where the contest appeared to be carried on; the boys hastened up, but too late to save the poor Jay, which was at the last gasp; in the agonies of death, however, it had contrived to infix and entangle its claws so firmly in the Hawk's feathers, that the latter, unable to escape, was carried off by the boys, who brought it home, when on examination, it proved to be a Kestrel.' The Windhover has often been known to pounce on the decoy birds of bird-catchers, and has in his turn been therefore entrapped by them, in prevention of future losses of the same kind.

It is a curious fact that notwithstanding their preying on small birds, the latter will sometimes remain in the trees in which they are, without any sign of terror or alarm. They have been known to carry off young chickens and pigeons. When feeding on insects which are of light weight, they devour them in the air, and have been seen to take a cockchaffer in each olaw. Bewick says that the Kestrel swallows mice whole, and ejects the hair afterwards from its mouth in round pellets 
- the habit of the other Hawks. Buffon relates that 'when it has seized and carried off a bird, it kills it, and plucks it very neatly before eating it. It does not take so much trouble with mice, for it swallows the smaller whole, and tears the others to pieces. The skin is rolled up so as to form a little pellet, which it ejects from the mouth. On putting these pellets into hot water to soften and unravel them, you find the entire skin of the mouse, as if it had been flayed.' This, however, is said by Mr. Macgillivray, nerer to be the case, but that the skin is always in pieces. Probably in some instances there may be foundation for the assertion of the Count, but only as exceptions to the general rule.

Mever observes, which every one who has seen the bird will confirm, as frequently, though not always the case, that 'when engaged in searching for its food, it will suffer the very near approach of an observer without shewing any alarm, or desisting from its employment, and continue at the elevation of a few yards from the ground, with out-spread tail, and stationary, except the occasional tremulous flickering of its wings; then, as if suddenly losing sight of the object of its search, it wheels about, and shifts its position, and is again presently seen at a distance, suspended and hovering in the same anxious search.' In the ardour of the chase, the Windhover has been known to drive a lark into the inside of a coach as it was travelling along; and another to brush against a person's head, in dashing at a sparrow which was flitting in a state of bewildered entrancement in a myrtle bush. Mr. Thompson mentions his having seen a Kestrel after a long and close chase of a swallow through all its turns and twists, become in its turn pursued by the same individual bird. They are often followed and teased by several small birds together, as well as by Rooks, as hereafter to be mentioned when treating of the latter bird. The note of the Windhover is clear, shrill, and rathe! loud, and is rendered by Buffon by the words 'pli, pli, pli,' or 'pri, pri, pri.'

I am indebted to my obliging friend, the Rev. J. W. Bower, of Barmston, in the East-Riding, for the first record that I am aware of, of the breeding of the Kestrel in confinement. The following is an extract from his letter dated November 30th., 1549, relating the circumstance:- 'A pair of Kestrels bred this summer in my aviary. The female was reared from a nest about four years ago, and the year after scratehed a hole in the ground, and laid six or seven ergst, but she voL. I. 
had no mate that year. Last winter a male Kestrel pursued a small bird so resolutely as to dash through a window in one of the cottages here, and they brought the bird to me. I put him into the aviary. with the hen bird, and they lived happily together all the summer, and built a nest or scratched a hole in the ground, and she laid five eggs, sat steadily, and brought off and reared two fine young ones.' Some pairs of Kestrels seem to keep together throughout the winter. About the end of March is the period of nidification. The young are at first fed with insects, and with animal food as they progress towards maturity. They are hatched the latter end of April, or the beginning of May.

The nest, which is plared in rocky cliffs on the sea-coast or elsewhere, is also, when it suits the purpose of the birds, built on trees; in fact quite as commonly as in the former situations; sometimes in the holes of trees or of banks, as also occasionally on ancient ruins; the towers of churches, even in towns and cities, both in the country and in London itself, also in dove-cotes. Sometimes the deserted nest of a Magpie, Raven, or Jackdaw, or some other of the Crow kind is made use of. When built in trees, the nest is composed of a few sticks and twigs, put together in a slovenly manner, and lined with a little hay, wool, or feathers. When placed on rocks, hardly any nest is compiled-a hollow in the bare rock or earth serving the purpose. Mr. Thompson mentions a curious fact of a single female Kestrel having laid and sat on four eggs of the natural colour, in April, 1848, after having been four years in confinement.

The eggs, which are of an elliptical form, and four or five in number, sometimes as many as six-six young birds having been found in one nest,--are dingy white, reddish brown, or yellowish brown, more or less speckled or marbled over witl darker and lighter specks or blots of the same. Mr. Yarrell says that the fifth egg has been known to weigh several grains less than either of those previously deposited, and it has also less colouring matter spread over the shell than the others; both effects probably occasioned by the temporary constitutional exhaustion the bird has sustained. In the 'Zoologist,' page 2596, Mr. J. B. Ellman, of Rye, writes, 'this year I received some eggs of the Kestrel, which were rather dirty; so after blowing them, I washed them in cold water, and much to my surprise the whole colour came off, leaving the eggs of a dirty yellow, speckled with drab. Not long after 
this I received five eggs from another Kestrel's nest, which were exactly like those 1 had previously, after they were washed.'

The following curious circumstance is thus pleasingly related by the Rev. W. Turner, of Uppingham, in the 'Zoologist,' pages 2296-7:- - In the summer of 1847 two young Kestrels were reared from the nest, and proved to be male and female: they were kept in a commodious domicile built for them in an open yard, where they lived in life of luxury and ease. This summer a young one of the same species was brought and put into the same apartment; and, strange to say, the female Kestrel, sensible (as we suppose) of the helpless condition of the new-comer, inmediately took it under her protection. As it was too infantine to perch, she kept it in one corner of the eage, and for several days seldom quitted its side; she tore in pieces the food given to her, and assiduously fed her young charge, exhibiting as much anxiety and alarm for its safety as its real parent could have done. But what struck me as very remarkable, she would not allow the male bird, with whom she lived on the happiest terms, to come near the young one. As the little stranger increased in strength and intelligence, her attentions and alarm appeared gradually to subsicie, but she never abandoned her charge, and its sleek and glossy appearance afforded ample proof that it had been well cared for. The three are now as happy as confined birds can be.

'The late Frederick Holme, Esq., of Corpus Christi College, Oxford, records that a nest of this species was observed to have been begun near that city; a trap was set, and five unale birds were caught on successive days, without the oc. currence of a single female; the last of them 'beng a young bird of the year in complete female plumage.' Agrain, at page 2765, the Rev. Henry R. Crewe, of Breadsall liectory, Derbyshire, zelates the following pleasing anecdote:- 'About four year's ago, my children procured a young Kestrel, which, when able to fly, I persuaded them to give it its liberty: it never left the place, but became attached to them. In the spring of the following year we missed him for nearly a week, and thought he had been shot; but one morning I observed him soaring about with another of his species, which proved to be a female. They paired, and laid several eggs in an old dove-cote, about a hundred yards from the Rectory; but being disturbed that season, as I thought, by some White Owls, the eggs were never hatched. The next spring he again brought a mate: they again bult, and reared a nest 
of young ones. Last year they did the same; but some mischievous boys took the young ones when just ready to fly. Though in every respect a wild bird as to his habits in the fields, he comes every day to the nursery window, and when it is opened, will come into the room and perch upon the chairs or table, and sometimes upon the heads of the little ones, who always save a piece of meat for him. His mate will sometimes venture to come within a yard or two of the house, to watch for him when he comes out of the room with his meat: she will then give chase, and try to make him drop it, both of them squealing and chattering to our great amusement. The male never leaves us; indeed he is so attached to the children, that if we leave home for a time he is seldom seen; but as soon as we return, and he hears the voices of his little friends calling him by name, he comes flying over the fields, squealing with joy to see them again. He is now so well known amongst the feathered tribes of the neighbourhood, that they take no notice of him, but will sit upou the same tree with him: even the lioolss appear quite friendly.'

Male; weight, about six ounces and a half; length, thirteen inches and a half, to even fifteen inches; bill, pale blue, or bluish grey, the tip black, and the base close to the cere tinged with yellow; cere, pale orange, or yellow; iris, dark brown, approaching to black; the eyelids are furnished with short bristles; forehead, yellowish; head on the crown, ash grey, each feather being streaked in the centre with a dusky line; on the sides, the same colour tinged with yellow: there is a blackish grey mark near the angle of the mouth pointing downwards, and a line of the same along the immer and upper edge of the eye; neck and nape behind and on the sides, lead-colour, faintly streaked with black, with a purplish tinge, as is the case with the other black feather's; chin and throat, yellowish white, without spots; breast, pale yellowish red, each feather streaked with dark brown, and a spot near the end of the same; back, bright cinnamon red, the shafts of each feather being blackish grey, with a spot of the same colour near the end.

The wings, which are rather long and broad, but narrow towards the ends, expand to the width of two feet three inches, and reach to within about an inch and a half from the tip of the tail: when closed they reach to within about two inches of it; greater wing coverts, brownish black, tinged 
with grey; primaries, brownish black, tinged with grey, margined with a paler shade, and the inner webs thickly marked with white or reddish white; the second is the longest, the third almost the same length, the fourth a little longer than the first, which is nearly an inch shorter than the second; underneath barred with darker and paler ash colour; secondaries, as the back on the inner side, namely, on the outer web, the inner being dusky with reddish white markings; and on the outer side as the primaries; greater and lesser under wing coverts, white, the latter beautifully spotted with brown. The tail, which consists of twelve long sounded feathers, the middle ones being an inch and a half longer than the outer ones, is ash grey, or bluish grey; the shafts, and a bar, which shews through near the end, of an inch in breadth, blackish brown, or purple black, the tip greyish white; upper tail coverts, ash grey, or light bluish grey, as the tail. The legs, which are feathered in front more than a third down, and covered all round with angular scales, and the toes, bright yellow or orange: the third and fourth are connected at the base by a very short web. Claws, black, tinged with grey at the base.

The female differs but little in sice from the male, at least in comparison with others of the Hawks. Length, from fourteen inches and a half to fifteen inches and a half; bill, cere, and iris, as in the male. Head, reddish, slightly shaded with bluish grey; neck, chin, throat, and breast, pale yellowish red streaked with dark brown-those on the sides forming transverse bands; back, dull rust-colour, barred with dark brown, each feather having four bands of brown and three of red, and tipped with the latter, the shafts dark browu. The wings expand to the width of two feet four inches, or even to two feet and a half; the spots are less distinct than in the male. Greater and lesser wing coverts, darker than in the male; primaries, brown, with transverse spots of pale red; secondaries, marked as the back. Greater and lesser under wing coverts, reddish white or yellowish white, with oblong brown spots. The tail and upper tail coverts, as the head, and the former barred with about ten narrow bars of blackısh brown, the end one nearly an inch in breadth, the tip reddish white. The under surface is more uniform in colour, and less distinctly barred than in the male. Under tail coverts, unspotted, as in the male. The feathers on the legrs streaked with small dark markings. 
The young are at first covered with white down, tinged with light sand-colour; iris, bluish black: when fully fledged, the bill is light bluish grey, tipped with yellowish grey or horn-colour; cere, pale greenish blue; iris, dusky, tinged with grey. Head, light brownish red, streaked with blackish brown. At the first moult the bluish grey appears mixed with the red in the male, and becomes more pure as the bird adrances in age. Neck on the sides, pale yellowish red streaked with dark brown; nape, as the head; chin, throat, and breast, pale yellowish red streaked with dark brown. Back, light red, but of a deeper shade than in the old birds-each feather crossed with dark brown bands. Greater and lesser wing coverts, dark brown, tipped and spotted with red; primaries, reddish brown, tipped with light red, and spotted with the same on the inner webs; secondaries, spotted on the outer webs and barred on the inner with red. The tail, light red, barred on the inner webs with eight bands of brown, the end one being three quarters of an inch in width; the tip dull reddish white, underneath it is light reddish yellow. At the first moult the bluish grey tint appears in the male, and the bars on both webs. The legs and toes light yellow; the feathers light reddish yellow-some of them with a dusky line in the centre. Claws, brownish black, the tips being paler.

'The dark markings become smaller as the bird advances in agc: those on the outer webs of the tail wear off first: those on the inner webs continue for two years. The female alters but little, assuming in a faint degree the greyish blue tint on those feathers which are of that colour in the male-the tail always remains barred. 



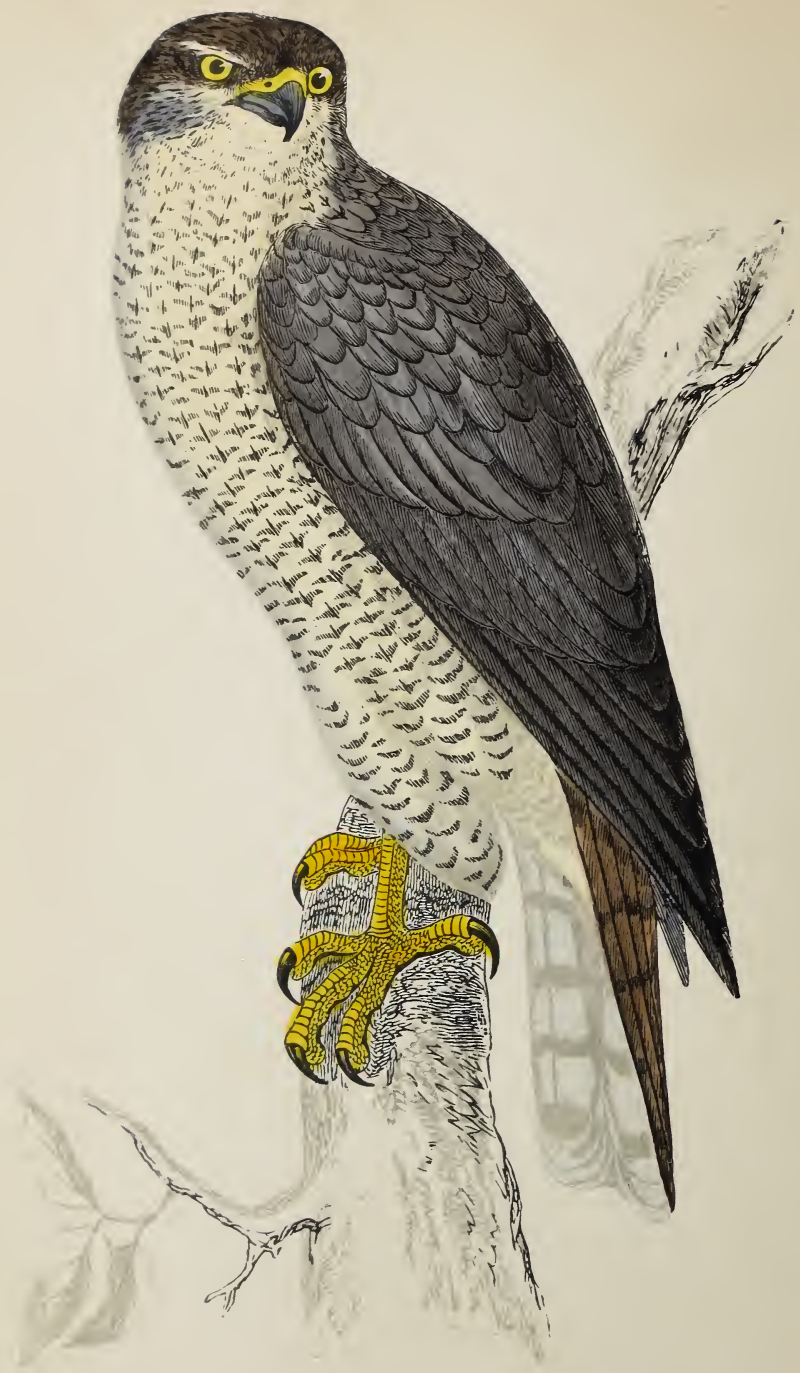





\section{GOSHAWK.}

Astur palumbarius,

Falco palumbarius,

Buteo palumbarins, Accipiter palumbarius,
Selby. Gould.

Pexxayt.

Fleming.

Jexyss.

Astur-Conjectured from Asturia, in Spain. Palumba-A Pigeon.

Palumbarius-

THIs species occurs in Europe, Asia, Africa, and perhaps in America; in the former, it has been known in Holland, Denmark, Norway, Russia, Sweden, Germany, France, Italy, and Switzerland; in Asia, in Chinese Tartary and Siberia; North Africa, also in North America, according to some opinions.

The Goshawk, though a short-winged species, and differing therefore in its flight from those most esteemed in falconry, was highly valued in that art, and flown at hares and rabbits, pheasants, partridges, grouse, ducks, geese, herons, and cranes. In Yorkshire, the only occurrence of this bird on record, was at Cusworth, near Doncaster, where one was killed in the year 1525, by the gamekeeper of W. B. Wrightson, Esq., M. P. A fine specimen in immature plumage was shot at Westhorpe, near Stowmarket, in the county of Suffolk, on the 20th. of November, 1819. An adult male was trapped by a gamekeeper in the same county, in the month of March, 1833; and in November in the same year, another was obtained in the adjoining county of Norfolk: it had alighted on the rigging of a ship, and was brought into Yarmouth. An immature male Goshawk was killed near Bellingham, in Northumberland, in the month of October, in the same year. A very fine female was shot at Bolam Bog, in the same county, on the 18th. of February, 1St1. Another female near the Duke of Northumberland's Park, at Alnwick, in the same year; and again a fourth, also a female, was caught in a trap near Beddington, by the gamekeeper of Michael Langridge, Esq. Dr. Moore records it as having been found occasionally on Dartmoor, 
in Devonshire. One was caught near Egham, in Surrey, early in the year 1846, in the following curious manner:- It was perched upon a gate-post, so intently engaged in watching a flock of starlings, that it did not perceive the approach of a man who came behind it, and caught it by its legs.

In the Orkney Islands it is not very unfrequently seen, according to Mr. Low, in his 'Fauna Orcadensis,' and also Mr. Forbes: it most probably occurs in the Hebrides also, if the fact be so, but Mr. Yarrell doubts whether the Peregrine may not have been mistaken for it. In Ireland, Mr. Thompson, of Belfast, says that it cannot be authentically determined to have occurred. In Scotland it seems to be indigenous, particularly in the central parts, in the Grampians of Aberdeenshire; on the Rivers Spey and Dee, where it has been said by Pennant to breed, and in the forest of Rothiemurcus, where it is known to do so. One was killed near Dalkeith.

Mountains as well as level districts are frequented by the Goshawk, but in either case it seems to prefer a variety of woodland and open country, and not to be partial either to the dense monotony of a forest, or the dangerous exposure of an open unsheltered plain. Mudie says that it also dwells in the rocky cliffs of the sea coast, but he gives no authorities for, or instances of, this being the case.

In general habits this species is considered to resemble the Sparrow-Hawk. At night it roosts in coppice wood in preference to lofty trees, and the lower parts of such instead of the top, rarely on rocks in the more open part of the country. 'When at rest,' says Meyer, 'he sits in a slouching attitude, with his back raised, and his head rather depressed; but does not drop his tail in the manner that some other birds of prey are in the habit of doing:' The male is said to be a much more spirited bird than the female, and to have been on this account the rather valued in the gay science; though its training was more difficult than that of some other species. It was flown at hares, rabbits, pheasants, grouse, partridges, pigeons, wild-geese, and herons. Great havoc is committed in preserves when the young ones are expecting food in the nest. At other seasons of the year the more open country is traversed for its own supply by the Goshawk. Like several others, perhaps all of the Hawk kind, the one before us is the object of the persevering and unaccountable attacks of the Rooks. Who that has lived in the country has not seen this, and observed it even from his childhood? Yet there are those, whose lot has unfortunately 
been cast in towns, who have never seen even so common a sight as this. I well remember, travelling some years ago on a stage coach over the Dorsetshire Downs, a lady who was going down into Devonshire with her son from London, seeing some gleaners in a field, observed that they were the first she had seen that year: 'they are the first,' said the youth, 'that I have ever seen in my life.'

This bird for the most part flies low in pursuit of its prey, which it attacks from below or sideways, not from abore like other Falcons, but occasionally it soars at a considerable elevation, wheeling round and round with extended tail, in slow and measured gyrations. Its flight is very quick, though its wings are short, and its game is struck in the air, if belonging to that element.

The food of the Goshawk, which is carried into its retreat in the woods, to be devoured there without interruption, consists of hares, rabbits, and sometimes mice; and of pigeons, pheasants, partridges, grouse, wild-ducks, crows, rooks, magpies, and other birds. 'According to Meyer,' says Selby, 'it will even prey upon the young of its own species.' Living prey alone is sought, and before being devoured it is plucked carefully of the fur or feathers-very small animals are swallowed whole, but the larger are torn in pieces, and then swallowed: the hair or fur is cast up in pellets. Sometimes a pigeon is heedlessly followed into a farm-yard, and sometimes the 'biter is bit' in the ignoble trap, in the act of attempting, like the Kestrel, to carry off the decoy birds of the fowler. Its appetite, though it is a shy bird, leads it into these difficulties, and so, again, when replete with food, and enjoying, it may be, a quiet 'siesta,' the sportsman steals a march, and down falls the noble Goshawk. Yarrell says that in following its prey, 'if it does not catch the object, it soon gives up the pursuit, and perching on a bough waits till some new game presents itself.'

'Its mode of hunting,' says Bishop Stanley, 'was to beat a field, and when a covey was sprung to fly after them, and observe where they settled; for as it was not a fast flyer, the Partridges could outstrip it in speed: it then sprung the covey again, and after a few times the Partridges became so wearied that the Hawk generally succeeded in securing as many as it pleased. To catch it a trap or two was set in its regular beat, baited with a small rabbit, or the stufled skin of one; but a surer mode, particularly in open unenclosed countries, was by prejparing what were called bird-bushes, about half-a-mile 
from each other. A large stake was driven into the ground and left standing, about seven feet in height; bushes and boughs were then laid round this post and kept loosely open, and hollow at the bottom, to the extent of ten or twelve yards round the post, for the Partridges to run into when pursued by the Goshawk, which they usually did after being disturbed two or three times. The Goshawk finding itself disappointed, and unable to follow them with its long wings amongst the bushes and briers, after flying round them for some turns, was sure to perch upon the top of the post, as the only restingplace at hand, and was as sure to be taken by a trap set there for the purpose.'

'His voice in times of danger,' says Meyer, 'is a loud single note, many times repeated, and bears a great resemblance to that of the Sparrow-Hawk; besides this cry, he utters another much resembling the note of the Peregrine-Falcon, which is chiefly used when engaged in a contest with some other bird of prey.

Its nest is said to be built in tall fir or other trees, near the trunk, and to be large in size, flat in shape, and composed of sticks, grass, and moss, loosely put together. The bird is believed to be in the habit frequently of occupying it for several years in succession, making the necessary repairs from time to time. Mr. Hewitson says that it 'is placed in some high tree in the interior of the woodland, except in those parts which are cleared, and free from timber.' During the time that the female is sitting she is fed by the male.

The egg's are from two to five in number, greenish or bluish white, often with and sometimes without, or nearly without streaks and spots of brown, or reddish, or yellowish brown. They are hatched about the middle of May, after an incubation of about three weeks.

The Goshawk is very strong and robust in make. Male; length, from one foot six, to one foot nine inches; bill, light blue at the base, bluish black towards the end, and bristled on the sides; cere, yellow; iris, bright yellow in the fully adult bird; over the eye is a broad white line spotted with black; head, flat, dark brownish black on the crown; neck, as the back, behind, the base of the feathers white, dull white in front; nape, white at the under end of the feathers, which are tipped with brownish black. Chin and throat, white, streaked with dusky; breast, greyish white, transversely waved with small bars of greyish black; each feather has 
several bars; the shafts of the same colour; back, dark bluish grey tinged with brown; there is an evanescent bloom of ash colour on the living bird, which fades away shortly after it is dead.

Wings, rather short; expanse about three feet seven inches; greater and lesser wing coverts, as the back; primaries, brown, barred with a darker shade, except towards the tips, which are dark brown; the shafts reddish, the inner margins whitish, especially towards the base; underneath, greyish white, the dark bars shewing through; secondaries and tertiaries, as the back; greater and lesser under wing coverts, barred with dusky transverse lines. The tail, which is long, wide, and rounded at the end, is brownish grey, with four, five, or six broad bands of blackish brown; the final band the widest, the tip white, the shafts yellowish brown, the base white; upper tail coverts, as the back; under tail coverts, white, with a few slight dark markings. The legs, which are yellow, of moderate length, and feathered rather more than a third down, are reticulated on the sides, and behind and before with large scales or plates: the feathers on the legs are shafted and marked as the breast, but the bars are narrower; toes, strong and yellow, the third and fourth united by a web which extends as far as the second joint of each; the first and second are nearly equal in size, the fourth longer and more slender, the third much longer; the sole of the foot is prominently embossed; claws, black, strong, and very sharp.

The female is much larger than the male, but closely resembles him in colour, the plumage only on the back being of a browner tint. When very old there is hardly any apparent difference between them. Length, from one foot ten to two feet two inches; bill, horn colour or bluish black; breast, as in the male, but tinged with rust colour; back, dark brown. The wings expand to about three feet nine inches; the bars on the tail are of a dark brown.

The young birds are at first covered with white or buffcoloured down. Bill, dark brown, paler at the base; cere, greenish yellow; iris, grey, pale yellow, reddish or yellowish orange, according to age: there is a white band over the eye, speckled with brown; head, reddish brown, the centre of each feather broadly streaked with dark brown, and edged with light yellowish red; crown, dark reddish brown, the feathers edged with dull white or rufous; neck behind, yellowish or 
reddish white, or light brown streaked with dark brown. Nape, light reddish brown, with an oblong dusky mark on the centre of each feather; throat, white or cream white, speckled with brown; breast, reddish or yellowish white, streaked longitudinally with brown on the centres of the feathers, the shafts still darker, narrowing towards the tip of each, until after the second moult: when the transverse bars appear, they are at first fewer in number and larger than in after years; back, reddish or yellowish brown, the feathers edged with a paler shade, or yellowish white; primaries, dusky, with dark brown, and tipped with whitish; secondaries and tertiaries, dusky, with greyish brown bars; greater and lesser under wing coverts, light brown, or rufous white, streaked as the feathers on the breast; tail, greyish brown, with four or five bars of blackish brown alternating with the former colour, and tipped with white; underneath, greyish white, barred with five bars of greyish brown; tail coverts as the back; under tail coverts as the breast, but only marked with brown at the tips. Legs and toes, dull yellow, inclining to green at the joints: the feathers on the legs are light brown or rufous white, streaked, but only on the shafts, as the feathers on the breast; claws, brownish black, those of the inner toes larger than those of the outer.

The young female is lighter coloured than the young male, and the dark markings on the breast are larger. It is some years before the fine grey of the back and the bluish white of the breast are assumed.

White varieties of this species have been sometimes met with, and some of a tawny colour with a few brown markings.

'I have compared,' says Macgillivray, 'British and French with American specimens, both in the adult and young states, and am perfectly persuaded that no real difference exists between them. Were we to form specific distinctions upon such trifling discrepancies as are exhibited by the Goshawk of America and that of Europe, we might find that our common ptarmigan, our bullfinch, wheatear, and kestrel, are each of two or three species. Cuvier, in my opinion, very strangely refers to the 'Falco atricapillus' of Wilson, which is the American Goshawk, as a species of 'Hierofalco,' that is, as intimately allied to the Jer-Falcon. The only name by which this species is known in Britain, is that prefixed to this article, but variously written-Goshawk, Goss-hawk, or Gos-hawk, and apparently a corruption of Goose Hawk.' 



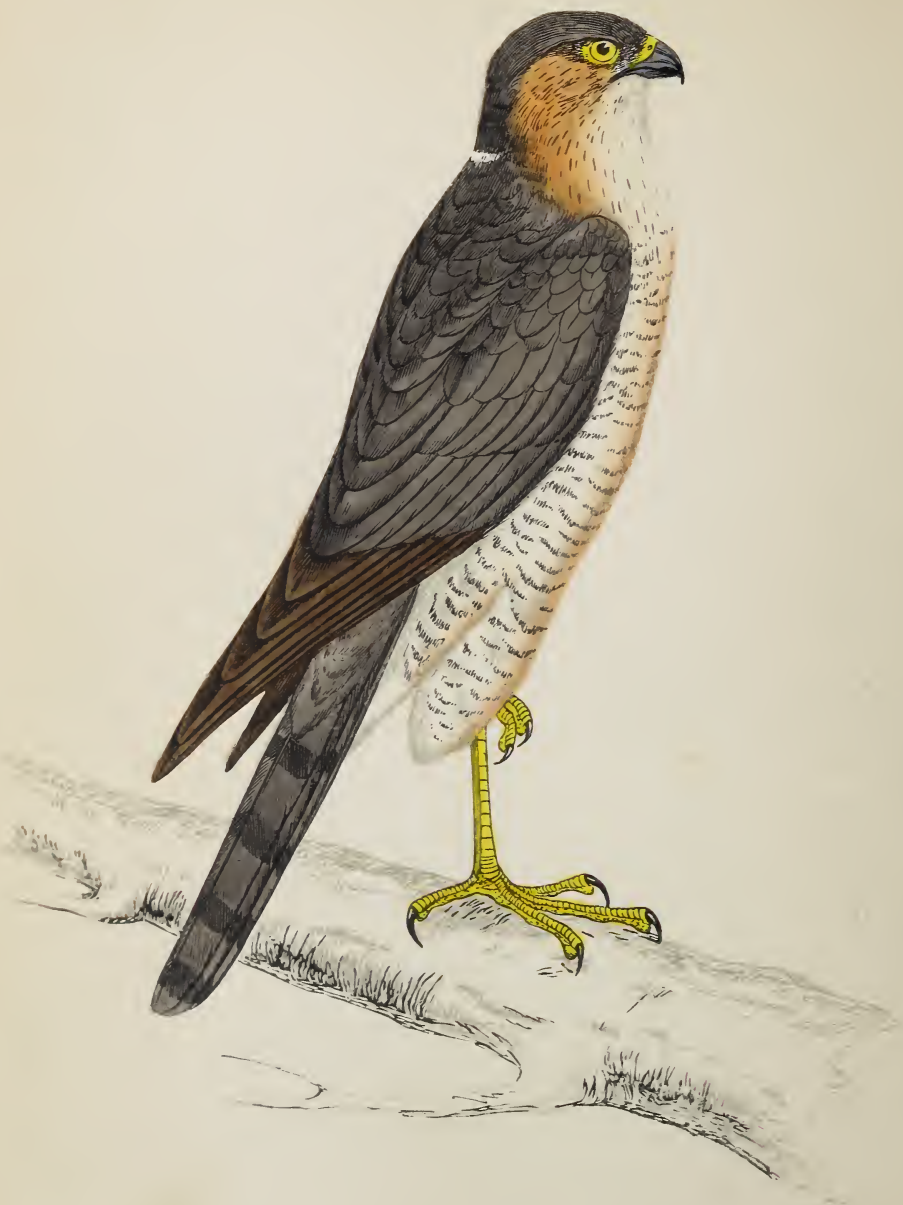






\title{
SPARROW-HAWK.
}

\author{
GWEPIA, OF THE ATCIENT BRITISH.
}

\section{Accipiter Fringillarius, Falco nisus, Buteo nisus,}

Shatw. Selby.

LiNNeCs. Lathaj. Flemixg.

Accipiter. Accipio-To take.

Fringillarius. Fringilla-A Finch.

'TAKE it for all in all,' there is perhaps no bird of the Hawk kind more daring and spirited than the one before us-next to the Kestrel, the most common of the British species of that tribe. It hunts in large woods, as rell as in the open fields, and may frequently be seen sweeping orer hedges and ditches in every part of the country. In the winter the males and females, like the chaffinches, appear to separate: the motive is of course unknown.

The Sparrow-Hawk is very numerons in various parts of the world; throughout Europe, from Russia, Denmark, Sweden, and Norway, to Spain; in Africa, even as far as the Cape of Good Hope; in Asia Minor and Japan; but does not occur. I believe, in America. It is numerous also in Ireland and Scotland, and occurs likewise in the Hebrides.

It prefers cultivated to uncultivated districts, even when the latter abound in wood, though wooded districts are its favourite resorts. The Rev. Leonard Jenyns says that in Cambridgeshire the males are much less frequently seen than the females; and this observation appears to be also general in its application, not as we may suppose from any disparity in numbers between the two, but from the female being of a more bold, and the male of a more shy and retiring disposition.

The organ of combativeness, according to phrenolog sts, would aplear to be largely developed in this bird: it seems to have universal letters of marque, and to act the part of a 
privateer against every thing that sails in its way-a modern specimen of 'Sir Andrew Barton, Knight.' It will fearlessly attack in the most pugnacious manner even the monarch of the air-the Golden Eagle, and has been known so far to obtain the mastery, as to make him drop a grouse which he had made a prize of: one has been seen after a first buffet, to turn again and repeat the insult; and another dashed in the same way at a tame Sea Eagle of R. Langtry, Esq., of Fortwilliam, near Belfast.

The Sparrow-Hawk occasionally perches on some projection or eminence of earth, stone, or tree, from whence it looks out for prey. If successful in the ken, it darts suddenly off; or if otherwise, launches into the air more leisurely. When prowling on the wing, it sweeps along, apparently with no exertion, swiftly, but gently and stealthily, at one moment gliding without motion of the wings, and then seeming to acquire an impetus for itself by flapping them; every obstacle in the way being avoided with the most certain discrimination, or surmounted with an aerial bound. Sometimes for a few moments it hovers over a spot, and after flying on a hundred yards or so, repeats the same action, almost motionless in the air. Its flight is at times exceedingly rapid, and it was formerly employed in the art of falconry, for hunting partridges, landrails, and quails. It often flies late in the evening. 'During the course,' says Sir William Jardine, 'some stone, stake, or eminence is often selected for a temporary rest; the station is taken up with the utmost lightness-the wings closed with a peculiar quiver of the tail, and the attitude assumed very nearly perpendicular, when it often remains a few minutes motionless; the flight is again resumed with as little preparatory movement as it was suspended.' It takes its prey both in the air and on the ground, but so great is the celerity of its flight, that a spectator sometimes cannot tell whether it has seized it on the latter or in the former element.

Unlike the Kestrel, which has a predilection for quadrupeds, the food of this species consists principally of the smaller birds, and some that are larger-snipes, larks, jays, blackibirds, swallows, sparrows, lapwings, buntings, pigeons, partridges, thrushes, pipits, linnets, yellow-hammers, bullfinches, finches, as also, occasionally, mice, cockchaffers and other beetles, grasshoppers, and even sometimes when in captivity, its own species: small birds are devoured whole, even legs and all; 
the larger are plucked. Of two which I lately had in my possession, kept in an empty greenhouse, one was found dead one morning, and partly devoured; and I have heard of another similar instance. Whether it had died a natural or a violent death is uncertain; but as they quarrelled over their food-they were both females-the latter is the most probable. Mr. Selby says that he has often known such cases. The first blow of the Sparrow-Hawk is generally fatal, such is the determined force with which, with unerring aim it rushes at its victim; sometimes indeed it is fatal to itself. One has been known to have been killed by dashing through the glass of a greenhouse, in pursuit of a blackbird which had sought safety there through the door; and another in the same way by flying against the windows of the college of Belfast, in the chase of a small bird. The voracity and destructiveness of this species is clearly shewn by the fact, witnessed by A. E. Knox, Esq., of no fewer than fifteen young pheasants, four young partridges, five chickens, two larks, two pipits, and a bullfinch, having been found in and about the nest of a single pair at one time. The young appeared to have been catered for in the place of their birth by their parents, even after they were able to fly to some distance from it. A pigeon has been known to have been carried by a female Sparrow-Hawk, a distance of one hundred and fifty yards.

Small birds in their turn sometimes pursue and tease their adversary in small flocks, but generally keeping a respectful distance; either a little above, or below, or immediately behind: their motive, however, is at present, and will probably remain, like many other arcana of nature, inexplicable. A male Sparrow-Hawk which had a small bird in its talons, has been seen pursued by a female for a quarter of an hour through all the turns and twists by which he avoiled her, and successfully so long as the chase was witnessed. Several instances have been known where houses, and in one instance a church has been entered by this bird, in pursuit of its prey-its own capture being generally the consequence; and one has been seen, immediately after the discharge of a gun, to carry off a dunlin which had been shot, and had fallen upon the water, poising himself for a moment over it in the most elegant manner, so that he might not be wetted, and then drooping his legs and clutching it most cleverly.

Great however as is the power of flight of the Sparrow-Hawk, 
as evinced in pursuit of its prey, the latter sometimes manage to rush into covert, or crouch very close to the ground, in time to save their lives. In one instance, considerable stratagy has been witnessed on both sides-a thrush, pursued by one of these birds over the sea, made the most strenuous effort: to gain a wood on the land, but her retreat was each time cut off by the Hawk, until the former took refuge on the mast of a steamer: the pirate dashed boldly after his prize, and was with difficulty scared from seizing it there and then. Baffled for the moment, he flew off himself to the wood, but on the poor thrush after some time, but alas! too soon, leaving her asylum and making for the shore, he was observed to sally from his ambush, and secure his reprieved victim. A lark thus harried has been known to make several attempts to fly into the breast of a gentleman-a swallow to find an actual sanctuary in that of a lady.

The author of the 'Journal of a Naturalist,' confirms the idea that their prey are sometimes fascinated by Hawks, by the following fact:- 'A beautiful male bullfinch, that sat harmlessly pecking the buds from a blackthorn by my side, when overlooking the work of a labourer, suddenly uttered the instinctive moan of danger, but made no attempt to escape into the bush, seemingly deprived of the power of exertion; on looking round, a Sparrow-Hawk was observed, on motionless wing, gliding rapidly along the hedge, and passing me, rushed on its prey with undeviating certainty.'

'In pursuit of prey,' says Bishop Stanley, 'they will not unfrequently evince great boldness. We knew of one which darted into an upper room, where a goldfinch was suspended in a cage, and it must have remained there some time, and continued its operations with great perseverance, as on the entrance of the lady to whom the poor bird belonged, it was found lead and bleeding at the bottom, and its feathers plentifully scattered about.' See, however, the affect-the good effect, of education. 'Even the Sparrow-Hawk', says the same kind-hearted writer, 'which by some has been considered of so savage and wild a nature, as to render all means for taming it hopeless, has nevertheless, in the hands of more able or more patient guardians, proved not only docile, but amiable in its disposition. About four years ago, a young SparrowHawk was procured and brought up by a person who was fond of rearing a particular breed of pigeons, which he greatly prized on account of their rarity. By good management and 
kindness, he so far overcame the natural disposition of this Hawk, that in time it formed a friendship with the pigeons, and associated with them. At first the pigeons were rather shy of meeting their natural enemy on such an occasion, but they soon became familiarized, and approached without fear. It was curious to observe the playfulness of the Hawk, and his perfect good humour during the feeding time; for he received his portion without any of that ferocity with which birds of prey usually take their food, and merely uttered a cry of lamentation when disappointed of his morsel. When the feast was over, he would attend the pigeons in their flight round and round the house and gardens, and perch with them on the chimney-top or roof of the house; and this voyage he never failed to take early erery morning, when the pigeons took their exercise. At night he retired and roosted with them in the dove-cote, and though for some days after his first appearance he had it all to himself, the pigeons not liking such an intruder, they shortly became good friends, and he was never known to touch even a young one, unfledged, helpless, and tempting as they must have been. $\mathrm{He}$ seemed quite unhappy at any separation from them, and when purposely confined in another abode, he constantly uttered most melancholy cries, which were changed to tones of joy and satisfaction on the appearance of any person with whom he was familiar. The narrator of the above concludes his account by adding, that he was as playful as a kitten, and as loving as a dove.' Meyer records an instance near Weybridge, of a pair of wood-pigeons building their nest and rearing their young in a cedar tree, which was at the same time the 'locale' of a pair of Sparrow-Hawks.

Before the nest is begun to be built, and while it is building, the birds may be seen soaring, though not very high, over the eyrie, and darting and diving about. When first the female begins to sit, she is shy, but becomes by degrees more assiduous in her task. The male does not watch, nor does either bird display the emotions evinced by the true Falcons in the care of their nest. When the young are hatched, rather more anxiety is depicted, and much courage shewn, at least in the case of the female, the male flying off from an enemy; and one instance is recorded of a female dashing at an intruder and knocking off his cap. A male has been known to feed the young for eight days after his partner had been captured, and as it would seem, by dropping the 
food to them from the air, so as to avoid the trap himself: all the birds thus brought to them were plucked, and had the heads taken off. Meyer says that the Sparrow-Hawk hides himself behind a bush to devour his prey, being very jealous of observation: he sometimes pounces on the decoy birds of the fowler.

Nidification commences in April.

The nest, which has frequently been the previous tenement of a crow, magpie, or other bird, is built in fir or other trees, or even bushes of but moderate height, as also in the crevices or on ledges of rocks, and on old ruins. It is large in size, flat in shape, and composed of twigs, sometimes with, but often without, a little lining of feathers, hair, or grass. It seems, however, to be but seldom its own architect, but the same nest is sometimes resorted to from year to year; in fact, it is the opinion of Mr. Hewitson, no mean one, that the Falcons very rarely make a nest for themselves-an action of ejectment is commenced in person against some other tenant at its own will of its own property-no notice to quit having previously been given; and, notwithstanding this legal defect, forcible possession proves to be nine points of the law, and 'contumely' is all the explanation that 'patient merit of the unworthy takes.'

The eggs are of a rotund form, bluish white in colour, much blotted, particularly at the base, with very deep reddish brown, and from three to five or six, or even seven, in number. They vary, however, very frequently in their markings, which, in some instances, are obscure and indistinct, and in others, the dark blots are at the smaller instead of the larger end. The young are hatched after an incubation of three weeks.

In no species of Hawk is the disparity in the size of the sexes more conspicuous than in the one at present before us. Male; weight, from five to six ounces; length, from eleven inches and a half, to one foot one inch. Bill, light blue at the base, bluish black at the end; cere, greenish yellow; iris, bright yellow: it is protected above by a strong bony projection, on which the feathers are partly white: bristles from the base of the bill overhang the nostrils. The feathers on the back of the head are white at the base, and seen more or less as they are raised, giving that part an iudistinct mark. The forehead and sides of the head are yellowish red. Neck, pale red in front, the shafts dark; chin and throat, very pale or rusty or yellowish red; each feather has five 
bands of white, and six of pale red and dusky; shafts partly dark. Breast, as the throat, waved in bands, the shafts with two or three dark marks on the upper part, but without on the lower; back, deep greyish blue, the shafts darker; an evanescent bloom pervades this colour in the bird, which fades away more or less quickly after its death. The wings are of moderate length, reaching beyond the middle of the tail, and expanding to the width of one foot eleven inches; in some specimens the fourth quill is the longest, the fifth almost as long; in others these relative lengths are transposed; shewing, as pointed out by me some years ago in the 'Naturalist,' that no distinctive character ought to be considered as certainly established from the length of the quill feathers of the wing. The first is rery short, equal only to the tenth, the second to the serenth, the third to the sixth. Greater wing corerts, pale red, barred with dusky brown; primaries, brownish, tipped with dark grey, marked on the inner webs with dusky bands, the inner margins of which are reddish white: the bands are conspicuous on the under side; the tips are darker than the rest; secondaries and tertiaries, marked as the primaries. The tail long, even, and consists of twelve rather wide and rounded bluish grey feathers, and has from three to six broad bands of blackish brown: it is tipped with greyish white; under tail coverts, reddish white, barred with rufous brown; the feathers on the legs barred with the same. Legs, light yellow, thin, and long; toes, light yellow; the latter are also long, the middle one being remarkably so, even in comparison with the others: the third and fourth are connected at the base by a web, which extends beyond the second joint of the latter, and curves forward as far as that of the latter: the soles of the feet are very protuberant; claws, black, pale bluish at the base: they are very thin at the points; the inner and hind ones are of equal length, and longer than the others.

Female; weight, about nine ounces; length, from about one foot two to one foot four inches; bill and cere, as in the male; iris, as in the male; head and crown, blackish grey; a white band passes from the forehead orer each eye, and runs into the white on the back of the neck; neck and nape, brown, the shafts dark in front; chin and throat, reddish white, with longitudinal lines of dark brown; throat and breast, reddish white, transversely barred more or less clearly with dark brown, each feather having five bars; in age the whole colouring approximates to that of the male; back, rufous or greyish 
brown. The wings expand to about the width of two feet four, or two feet five inches; underneath they are pale grey, more or less tinged with rusty red, and barred with dark brown; under wing coverts, light red, barred with dusky brown, primaries, secondaries, and tertiaries, greyish black, obscurely barred on the outer webs with dark brown, and spotted with two or more large yellowish white spots on the inner webs in the intervals, excepting towards the tips; greater and lesser under wing coverts, as the breast, but the bars are broader. The tail, which is brown, has four darker bars of the same on the middle feathers, and five on the side ones; their edge is better defined on the lower than on the upper side; tip, whitish; under tail coverts, white, with a few dark markings on the outer ones, as on the breast, but broader; legs and toes, yellow; claws, black.

The young are at first covered with white or greyish white down-even in the nest the females are distinguishable by their superior size. When fledged, the bill is dusky brown at the tip, and bluish at the base; cere, greenish yellow; iris, light brown. Head and neck, reddish brown, with some partly white feathers on the back of the latter; the middle of each feather being dark greyish brown; breast, reddish white, with large oblong spots of a dark brown colour; the middle of each feather being of that colour, transversely barred with yellowish red or light rust-colour--the bars becoming by degrees narrower and brighter. Back, reddish brown; legs and toes, greenish yellow, tinged with blue. Wings and tail, dark reddish brown, then bluish grey, which becomes more pure as the bird advances in age; the tail has three dark brown bands. The female is larger: she also has the partly white feathers on the back of the head; the breast is whiter than in the male, and the marking on it larger; the upper parts browner. I have recently seen in the admirably well-preserved collection of Mr. Chaffey, of Dodington, Kent, a most remarkable variety of this bird -a male, the whole plumage as white as snow. 



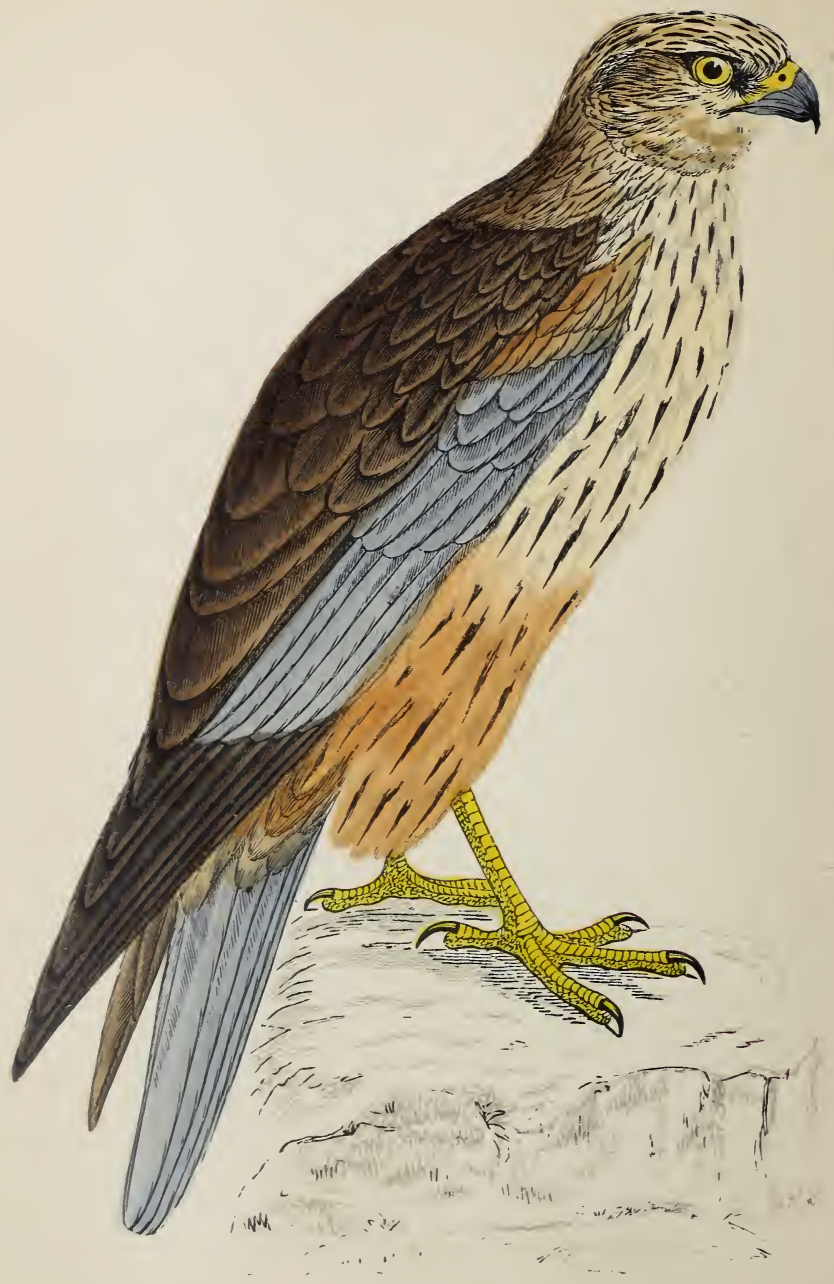






\section{MARSH HARRIER.}

HOUR BUZZARD. WHITE-HEADED HARPY. PUTTOCK.

DUCK HAWK.

Circus rufus,

Fulco aruginosus,

"6 arundinaceus,
Brisson. Selby.

Linxeus. Pennaxt.

Bechsteis.

Circus-The Greek name of some species of Hawk.

Rufus-Red.

WHY the birds of the genus at which we have now arrived should be called Harriers more than any others of the Hawk family, I know not. Yarrell suggests that the origin of the name has probably been derived from their beating the ground somewhat in the manner of a dog hunting for game. Their natural order is certainly in close proximity to the Owls; the most remarkable 'feature' of similarity being the ruff-like circle of feathers round the face, somewhat after the fashion of what in the human subject is called a calf-lick, and which is set up or depressed by the voluntary action of the bird.

These Harriers are found in the temperate regions of three, if not four quarters of the globe. They are common in Norway and Sweden, Denmark and the south of Russia, Germany, France, Italy, Spain, Holland, and Turkey; less frequently in Switzerland, and the south of Europe: in Egypt, and other parts of Africa; the Himalaya Mountains, Asia Minor, and other districts of Asia. Wilson and Buonaparte consider this species to be the same as the American one they describe by the name of the Marsh Hawk, but several distinctive marks, as for example the difference in the length of the tail beyond the wings, will appear on reading their account, though they are right in overruling the erroneous reason given by Pennant, namely, the thickness of the legs, for supposing the birds distinct; whether, therefore, our species is found in America, I am not able to say. 
In this country they are indigenous, remaining with us all the year round, in most of the counties of England and Wales; in Ireland, from Antrim to Cork; in Scotland and the Hebrides. Their numbers however, like those of so many others of the birds of prer, are becoming gradually fewer, and anything but 'beautifully less.' From Scotland to Sussex an ornithological lament over the glories of the departed is raised. 'Fuimus' must soon be the motto of the Marsh Harrier, as well as of 'the Bruce,'

They frequent, as the name suggests, open moors and wild plains, in which marshes or lakes are found, but appear to be partially migratory. Attempts have been made to train them for falconry, but they have been found very intractable.

The flight of these birds, which is not very swift, is light and airy, but unsteady. Occasionally they rise to so great a height as to be all but invisible to the eye, and at the time when the female is sitting, the male is often to be seen soaring above the nest, and performing a variety of attractive erolutions. They seldom alight on trees, even to roost at night, but resort to the concealment of beds of reeds, and in the day-time perch on a hillock, a rail, or the ground. They do not long remain stationary, but keep beating their hunting grounds in search of prey, and they often frequent the same locality for sereral days together, and follow the like course at the same hour of the day.

The food of the Marsh Harrier consists of rabbits, waterrats, mice, and other small animals, whether found dead or alive; land and water reptiles, the young of geese, ducks, and other water-fowl, and of partridges; as also small birds, such as quails and larks; the eggs of birds, insects, and Bewick and others say fish, and Mudie large carrion. They take their prey from the ground or the water, not in the air. In the autumn they sometimes leave the moors, and come down to the coast in quest of sea-birds, perching on the rocks until they perceive any that they can seize. A singular anecdote of one of this species, communicated by Mr. R. Ball, is recorded in Mr. Thompson's 'Natural History of Ireland:''One of these birds, which I had some year's since, lost a leg by accident. I supplied it with a wooden one, and the dexterity it acquired with this stump, both in walking and killing rats, was astonishing. When a rat was turned out, the bird pounced at it, and never failed to pin the animal's head to the ground with the stump, while a few grasps of 
the sound limb soon terminated the struggle.' This reminds one of the gallant Witherington immortalized in 'Chevy Chase,' 'For when his legs were shot away, he fought upon his stumps.'

Towards the end of the month of March, nidification commences, and incubation in April; the young are hatched in May. The nest is usually built in the high reeds which fringe the margin of the lake, pond, or swamp; in a tuft of rushes, fern, or furze; on a mound, at the edge of a bush, or on the top of the stump, or in the hollow of the branches of some tree in the former situation. It is a very rude fabrication, and composed of sticks, with reeds, flags, sedge, rushes, grass, or leaves; sometimes forming a mass a foot and a half above the ground.

The eggs are from three to five in number, slightly tapered at one end, and generally perfectly white, or white with a slight tinge of blue. Bewick says that they are irregularly spotted with dusky brown; and Macgillivray describes some he had seen which had a few faint light brown marks.

This species varies exceedingly in plumage. Male; weight, about twenty-one ounces; length, one foot seven to one foot nine inches; bill, bluish black; cere, yellow; iris, yellow; head, but sometimes only the crown, yellowish or white; in some specimens the shafts are dark; in others, it, as well as the whole of the plumage, is ferruginous brown; in others it is yellowish white tinged with rufous, and streaked with dark brown; and in others, only a shade lighter than the rest of the brown plumage. The upper part of the neck is encircled by a ruff of stiff feathers; nape, yellowish white, or white; chin and throat, nearly white. Breast, ferruginous brown, streaked with a darker shade; the shoulders are sometimes white. Back, ferruginous brown, the feathers margined with a lighter shade

The wings, when cinsed, reach nearly to the end of the tail; greater wing coverts, ferruginous brown, but in older birds partially or entirely ash grey; and in some tipped with reddish brown; sometimes yellow; lesser wing coverts, the same; primaries, brownish black, or dark grey in old birds; the third is the longest in the wing; the first and second are short; secondaries, ash grey, tipped in some cases with reddish brown; tertiaries, ferruginous brown, margined with a lighter shade; in old birds partially or entirely ash grey; larger and lesser under wing coverts, light brown. Tail, ash grey; in some instances tipped with reddish brown; tail coverts, ferruginous 
brown; under tail coverts, the same, each feather streaked with dark brown. Legs, long and yellow, feathered to within three inches of the foot; toes, long and yellow; claws, black and slender, and not much hooked; the outer and middle ones are united by a membrane, and the latter is somewhat dilated on the inner edge.

Female; weight, twenty-eight ounces and a half; length, from one foot ten inches to two feet; bill, dusky or bluish black; cere, yellow; iris, yellow; Selby says dark brown; but this must be a young bird. Head, yellowish, sometimes streaked with brown. The neck is surrounded by a ruff of stiff feathers; nape and chin, as in the male; throat, as the head; breast, reddish brown; back, dark brown. The wings expand to the width of four feet five or six inches. Greater and lesser wing coverts, primaries, secondaries, tertiaries, greater and lesser under wing coverts, tail, and tail coverts, legs, toes, and claws, as in the male.

The young in the first year, formerly described as a separate species by the name of the Moor Buzzard, have the bill bluish black; cere, pale yellowish green; iris, dark brown; crown of the head, dark cream-colour. Neck, nape, and chin, brown; throat, yellowish white or light rust-colour; breast and back, dark reddish brown with a metallic tint. Greater wing coverts, sometimes tipped with white; lesser wing coverts, primaries, secondaries, and tertiaries, as the back. Larger and lesser under wing coverts, brown of a lighter shade; tail underneath, pale ash grey; tail coverts, as the back. Legs and toes, pale yellowish green; claws, black. In their second summer the plumage becomes more rufous in some parts, the tail lighter coloured, and on the ruff and the shoulders, and front of the neck, some yellowish white spots shew themselves; and an ash grey gradually spreads itself on the greater wing coverts. In the third year, the back is light rufous brown; the tail pale grey, without any bars, and its under surface, as are the wings underneath the quill feathers, of a silvery white.

Latham describes a specimen of this bird as of a uniform brown, with a tinge of rust-colour; Montagu one which had the head, some of the wing coverts, and the four first quill feathers, white; Selby one which had the four quill feathers, throat, part of the wing, and the outer tail feathers, white; and the Rev. Leonard Jenyns one of which the lower half of the breast was white, and others spotted with white in various parts. Some have the upper part of the breast, and others 
part of the back of the neck white; others, without the white head, have a greyish spot on the throat. Sir William Jardine describes one as entirely brown, excepting the forehead and back of the head, throat, sides of the mouth, and tips of the quills, which were white; another, pale reddish brown, the upper tail coverts and base of the outer tail feathers pale yellowish red, the former shewing a bar; the back of the head pure white, extending over each eye.

I have much gratification in communicating the following new theory of what will, I have hardly a doubt, prove to be the fact of the case respecting the striking changes in the plumage of this bird. Mr. Arthur Strickland has written down for me the substance of a previous conversation on the subject, as follows:- This bird has a regular periodical change of plumage, that has not, as far as I know, been before explained. It begins life in a dark plain brown plumage, with a distinctly defined dark cream-coloured head; it then leaves this country, as it is a regular migratory species; it returns the next spring in a much lighter brindled brown plumage, with a pale orange-coloured head, which pale orange in old specimens extends over part of the neck and shoulders; but in the intermediate time it has undergone a marked change of plumage, losing entirely all portions of the cream-colour of the head, which is in fact only a breeding state of dress. In this winter dress it is of very rare occurrence in this country, but if by chance it does occur, it will be found as above described, in all respects answering the description of the Harpy Hawk of Brisson; but specimens taken upon their first arrival in spring, may be often got with the creamcoloured head only partly developed.'

It is a very curious fact that Mr. Arthur Strickland has met with no young birds from the nests in Yorkshire without the white cap on the head, and the Rev. Leonard Jenyns none in Cambridgeshire that had it; and further, in a communication to Mr. Allis, Mr. Strickland says that the only adult bird without the white cap he ever saw, was from Cambridgeshire, which is certainly very singular. Can there be two species confounded together? 


\title{
HEN HARRIER.
}

\begin{abstract}
WHITE HAWK. DOVE HAWK. BLUE HAWK, (MALE.) RINGTAIL, (FEMALE.)
\end{abstract}

Circus cyaneus,
Falco cyaneus,
" torquatus,
" pygargus,

Circus-The Greek name of some species of Hawk.

Cyareus-Blue-blue-coloured.
Fleming. Selby.

Montagu.

BRISSON.

LinNAUS.

IT is somewhat surprising that Mr. Yarrell should appear to give Montagu the credit of determining that the two supposed species, the Hen Harrier and the Ringtail, are identical, when the fact had been long previously observed by Willughby.

'It has become known,' says Yarrell, 'on account of a supposed partiality to some part of the produce of the farm-yard, by the more general name of Hen Harrier.' The Kite and the Sparrow-Hawk have, however, an equal claim to the distinction. 'The male,' says Mr. St. John, 'is distinguished from afar by his nearly white plumage.' Bewick's description of this bird seems to me, in some particulars to apply to the next species.

The Hen Harrier is widely distributed, being found in the low and flat districts of France, Germany, Holland, Scandinavia, Russia, Italy, Turkey, Greece, and other countries of Europe; in India, Japan, Asia Minor, Siberia, and other parts of Asia; in Africa; and possibly in New Holland, and in America; but Selby observes that some doubts still remain as to the specific identity of the latter species and ours.

In this country it is generally dispersed in England, Ireland, and Scotland, though in no part numerous. It is a perennial inhabitant of the Hebrides and Orkneys. It seems 




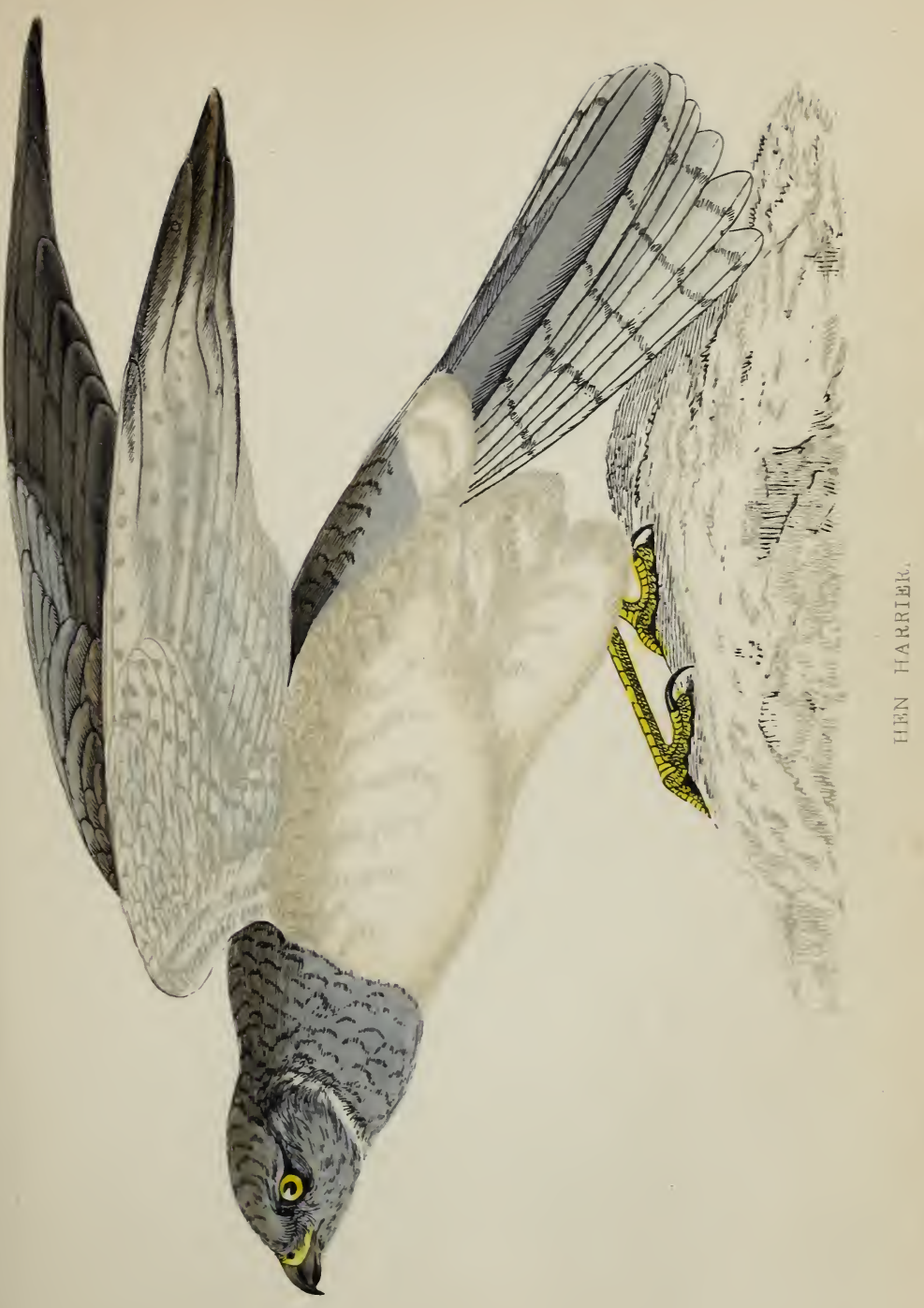



to frequent the lower lands in the winter, and the higher in the summer.

The Hen Harrier attaches itself to open wastes, downs, and commons, wide moors, fens, and marshy situations. It appears to roost only on the ground, and is easily trapped.

Its flight is low, but light and buoyant, though not very swift. Sometimes it hovers in the air for a short time, somewhat in the manner of the Kestrel: again it sails on motionless pinions, but generally with quick pulsations of the air. Before commencing the nest, both birds may be seen soaring about and sporting in the air: occasionally they do so at a considerable elevation, wheeling in circles. Its attitude when settled, is nearly erect, and it generally selects some little eminence to alight on.

It beats its hunting grounds with regularity, both of plan and time, and with careful investigation. Game, both old and young-curlews, partridges, pheasants, fowls, lapwings, buntings, larks, snipes, stonechats, and other larger and smaller birds, leverets, rabbits, rats, mice, and other small animals, lizards, vipers, snakes, and frogs, and occasionally dead fish compose its food, and all these it pounces on on the ground. If it does chase any thing in the air, it does not seize it there, but drives it first to the earth. One, however, has been seen flying off with a grouse. Mr. Thompson relates of another as follows:- A sportsman having killed a snipe, was in the act of reloading his gun, when the Hawk sweeping quickly past him, made a stoop to carry off the snipe, and when just seizing the bird, was itself brought down by the second barrel.' No fewer than twenty lizards were found in one which was killed near London. In one kept in confinement, the upper bill grew so much hooked as almost to prevent the bird from feeding; but by cutting half an inch off it, the difficulty was removed.

The note is loud and clear, and resembles in some degree that of the Kestrel.

The nest, which is built on open wastes, and frequently in a furze cover, and placed on or near the ground, is composed of sticks rudely put together, sedge, reeds, flags, and other coarse materials. It is made of considerable height, as much as a foot and a half; perhaps as a safeguard against flood. One has been known thus raised to the height of four feetperhaps a second story had been added to a former tenement. The male assists the female occasionally in the task of incu- 
bation. The young are hatched early in June: both parents are said to supply them with food.

The eggs are four or five in number, sometimes, I believe, six; and most frequently white, or bluish, or greenish white, and in some instances more distinctly spotted, but often slightly marked with yellowish brown, or light brown. Bewick describes some as of a reddish colour, with a few white spots.

Male; weight, about twelve or thirteen ounces; length, from sixteen to eighteen inches, or eighteen inches and a half; bill, black; cere, yellow; iris, yellow; a number of bristles almost hide the cere at the base of the bill. The head, which is bluish grey, is surrounded by a wreath of short stiff feathers, white at the base, and slightly tipped with grey; neck, ash grey; nape, the same, but occasionally mottled with brown, as are other parts of the plumage while in the changing state; chin and throat, fine light grey. Breast on the upper part, grey; on the lower part white, or bluish white. Montagu describes one specimen which was streaked with dusky; back, fine light grey. The wings reach to within two inches of the end of the tail, and expand to above three feet-the first quill is shorter than the sixth: all the feathers very soft. Mr. Yarrell quotes in his work an observation which I had recorded some years before in my magazine, the 'Naturalist,' as to the fourth quill feather in the female being the longest, and the third in the male. He suggests that in such cases the birds may have been killed in autumn before the ultimate relative length of the feathers has been gained. The question, however, will a puzzling one, why one feather should grow faster than another-'who shall decide?' A difficulty is certainly put in the way of founding specific distinctions on the relative length of the quill feathers, as I have already pointed out in the case of the Sparrow-Hiawk, and shall have occasion again to do in that of the Snowy Owl.

Greater wing coverts, grey; lesser wing coverts, grey, but they seem to be the last part of the plumage that loses the ferruginous tint of the young bird. The first six primaries nearly black, white at the base, and tipped with grey; the others grey on the outer webs, white on the inner, and faintly barred with dark grey: the first feather is very short, and the lightest coloured; the fourth the longest, the third nearly as long, the fifth a little longer than the second, the seventh about the length of the first; secondaries and tertiaries, grey on the outer webs and tips, white on the inner webs; larger 
and lesser under wing corerts, white. The tail white, except the two middle feathers, which are grey, with sometimes a few markings; the inner webs of the outer ones are barred with eight dark grey or dusky bars; the outer webs grey, without bars generally, but some have them slightly barred with rustcolour: underneath it is greyish white, with traces of five darker bars; upper and under tail coverts, white. Legs, long, feathered, and as the toes, yellow; claws, black.

Female; weight, about eighteen ounces; length, one foot eight to one foot nine inches; bill, black; cere, rellow; iris, yellow; the eyes are surrounded with white or pale greyish yellow; bristles, as in the male; forehead, pale greyish yellow. Head, brown, the feathers margined with rufous, forming a faint collar; neck, as the head; the ruff, which is more distinct than in the male, dusky, or reddish, or yellowish white, or white; the shafts of the feathers brown; nape, rufous; chin, white; throat, light rufous, the feathers marked as on the breast. Breast, yellowish white, or pale rufous brown, streaked with orange brown or dusky in the centre of each feather, and the shafts still darker. Back, brown, varied with yellowish or reddish brown.

The wings as in the male, except as to the length of the quills, (vide supra) - they expand to from two feet and a half to two feet ten inches. Greater and lesser wing coverts, brown, margined with rufous; primaries, dusky, the outer webs cinereous, barred beneath with white and dark brown; secondaries and tertiaries, dusky, slightly edged with a paler shade; greater and lesser under wing coverts, reddish white, with dark centres to the feathers. Tail, light brown, white at the base, barred on the side feathers with waved bars of darker and lighter brown-six on the middle, and four on the side feathers - the lighter ones shaded to rufous on the inner webs, which appear whitish underneath; the last bar is the widest; the inner webs, excepting those of the two middle feathers, pale reddish grey; the shafts pale brown. In some specimens the outer feather on each side is light, and without bars; the tip of the tail whitish or pale rustcolour; underneath the tail is paler, the middle feathers barred with dusky black and dull white. Tail coverts, white, sometimes with a few brown markings; under tail coverts, as the breast, but lighter and less marked, sometimes spotless. Legs, yellow, feathered in front as in the male, one third down; toes, yellow; claws, black. 
The young are at first covered with white down-the males are smaller than the females, and lighter coloured. The females, as they advance in age, change the brown for more of grey, and the light for greyish yellow; the bars on the wings shew more distinctly, from the intervals becoming lighter, which also encroach upon them. The males gradually change from brown to grey, commencing the change when about a year old: the former, however, is their bridegroom's attire. When fully fledged, the bill is blackish brown, yellow at the base; cere, yellow; iris, dark brown; head and neck, brown edged with rufous; the ruff the same, but paler at the edges. Breast, brownish red, each feather having a central band of brown; back, rich brown; primaries and secondaries, edged with brownish grey, the dark bands indistinct, except on the inner webs. The tail has four bands of dark brown, and four of pale red, the end one of the latter colour fades into white; upper tail coverts, white spotted with brown; legs, Jellow; toes, blackish brown 



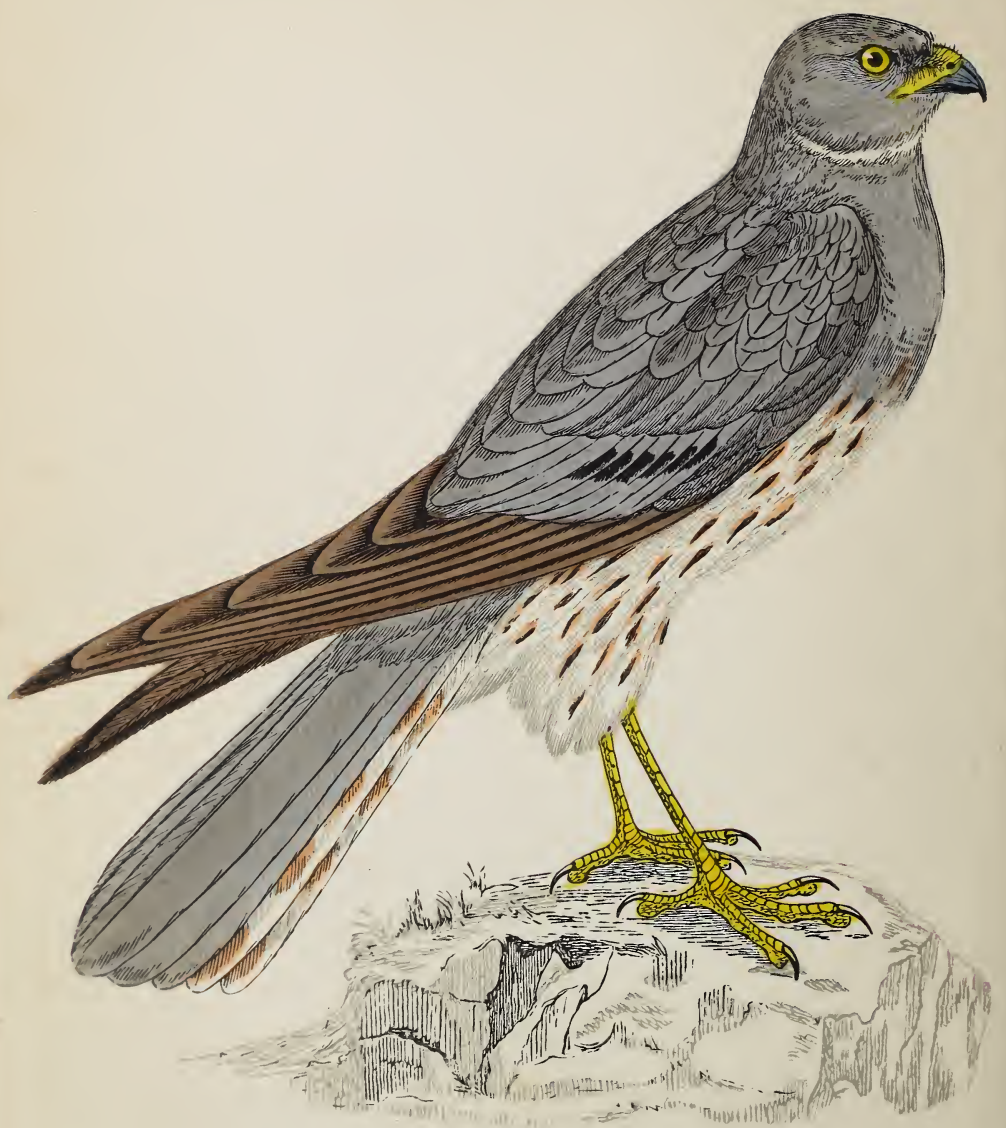






\title{
MONTAGU'S HARRIER.
}

\author{
Circus Montagui, \\ Falco hyemalis, \\ YARRELL, \\ " cineraceus, \\ Buteo cineraceus, \\ Pexsant. \\ Montagu. \\ Flening. Jexins.
}

Circus-The Greek name of some species of Hawk. Montagui-Of Montagu.

I HAVE followed Mr. Yarrell in both the Latin and the English denominations of this species, as the previous one has an equal right with it to the descriptive title of 'ashcoloured.' The compliment too of the name is properly claimed for Montagu, the first to discriminate the two species - 'huic des nominis hujus honorem.'

Montagu's Harrier occurs in the southern countries of Europe -in Hungary, Poland, Silesia, Austria, Dalmatia, Illyria, Italy, Switzerland, Holland, Germany, and France; in Asia, as far east as India, and in Africa. In America it appears to be unknown.

Different views seem to have been taken as to the numbers of this bird among us. Mr. Hewitson's account seems to me to be the correct one, that 'though at one time more abundant than has been supposed, it is now becoming rare, and exceedingly difficult to procure.' It has been mostly met with in the southern and south-western counties: one in my possession, a young bird, was shot on the western borders of Dorsetshire. In Yorkshire various specimens have been obtained, especially, as might readily be imagined by those who know the locality, on Thorne Moor, contiguous to the 'Level of Hatfield Chase.' In Sussex, Mr. Knox says that it has been more often met with than the Hen Harrier. It becomes still less frequent towards the north, but appears to be known in Scotland, in Sutherlandshire, where it breeds near Bonar Bridge, and doubtless in other counties also. In 
Ireland it is believed that one if not more specimens have occurred, but none have been preserved.

The flight of this species resembles that of the Hen Harrier; but, Selby says, that it is more rapid and more strikingly buoyant.

Its food consists of small birds, such as larks and finches; as also lizards, frogs, and other reptiles, and even the eggs of small birds.

Nidification commences in March or April; incubation in May; and the young are hatched in June or July, and moult in August.

The nest is built on the ground, generally in some tuft of furze, and is composed of grass, sedge, rushes, or flags.

The eggs are usually four or five in number, rarely six; they are white, or white with a cast of light blue, and in some instances spotted with brown.

Male; weight, between nine and ten ounces; length, about one foot five or six inches; bill, dusky black, the tip slender and very acute. Cere, dull yellow; iris, yellow; bristles almost hide the cere; head, neck, and nape, light ash-coloured; the ruff is but obscurely visible. Chin, throat, and breast, light ash-coloured on the upper half, white on the lower, the latter streaked down the shafts of the feathers with ferruginous. Back, ash-coloured, rather darker or brownish on the upper part.

The wings expand to the width of three feet eight or nine inches, and extend, when closed, beyond the tail. Greater and lesser wing coverts, ash-coloured; primaries, nearly black, greyish at the tips; the third quill is the longest in the wing, being an inch longer than the second, the first is a little longer than the fifth; the first are the darkest, and gradually become lighter; secondaries, ash-coloured, the latter crossed by three dusky black bars, of which only one is visible above when the wings are closed; tertiaries, ashcoloured; larger and lesser under wing coverts, white, barred with light ferruginous. Middle feathers of the tail, ashcoloured, the outer ones white, barred with ferruginous; underneath it is dull white, barred with dusky grey; under tail coverts, as the lower half of the breast. Legs, slender, yellow, and feathered in front about a fourth down; toes, slender and yellow; claws, black.

Female; weight, between thirteen and fourteen ounces; length, one foot six to one foot seven inches; bill, nearly black; cere, dull yellow; iris, yellow, over the eye is a streak 
of dull white; bristles as in the male. Crown and back of the head, reddish brown, edged with a lighter shade; neck, brown; nape, brown, edged with yellowish white. Chin and throat, light yellowish rufous; breast, iight reddish brown, streaked with a darker shade. Back, dark brown, the feathers margined with ferruginous. Wings, as in the male, in proportion; greater and lesser wing coverts, as the back; primaries, secondaries, and tertiaries, dusky; greater and lesser under wing coverts, brown. Tail, dark brown on the centre feathers, the side ones barred with two shades of reddish brown, except the outer, which are barred with reddish brown and white. Tail coverts, brown, mixed with a little white. Legs and toes, rellow; claws, black. In advanced age the whole plumage becomes lighter.

The young male in the first year has the head and neck ferruginous, each feather streaked with dark brown; chin, throat, and breast, uniform reddish brown. In the young female the breast is without the streaks; back, dark brown, (in my specimen nearly all the feathers are margined with light rufous;) greater and lesser wing coverts, the same, margined with ferruginous; wings underneath, as the breast; primaries, secondaries, and tertiaries, dull black; both the latter tipped with rufous. Tail, with five bands of dark and four of greyish brown; underneath, dull reddish white, with four or five bands of brownish grey; tail coverts, white tipped with rufous; under tail corerts, as the breast. In the next stage the head is brown and rufous; chin and throat, light grey; breast, white. Greater wing coverts, dark brown; lesser wing coverts, lighter brown, varied with rufous and grey; primaries and secondaries, blackish brown. Tail, except the two middle feathers, barred with brown and rufous; the middle ones have the outer webs light grey; the inner grey, with five dark brown bands; underneath it is barred with greyish white and brown. Under tail coverts, white, with a rufous streak on the centre of each feather.

These birds vary extremely in plumage, the males occurring in every stage of gradation from the garb of the female to their own perfect hue; some even vary on different sides. I have seen two in the collection of Mr. Chaffey, of Dodington, Kent, and have heard of another, of a uniform dark colour, almost black. A fourth, a similar variety, is described in the 'Zoologist,' as having the nape irregularly marked with white. 


\section{SHORT-EARED OWL.}

WOODCOCK OWL. SHORT-HORNED OWL. HAWK OWL. MOUSE HAWK.

Strix brachyotos,

" ulula,

Otus brachyotos,
Montagu, Bewick.

LATHAM.

Selby. Gould.

Strix-A kind of Owl.
Ouss, (plural ota)-An ear.

THE remark made at the commencement of the next article, applies in a modified degree to the bird whose natural history is at present under consideration. I hope we shall never ourselves be so overwise as to undervalue the tales of our childhood; and, if so, the question 'what ears you have!' and the philosophical answer 'the better to hear with;' will never be effaced from our recollection.

The Short-eared Owl is found in Germany, Holland, most parts of Europe, and North and South America.

Unlike the next species, this one avoids the shelter of woods, and makes itself conspicuous in the open country, seeming to prefer moist situations: in the eastern side of the island it is the most numerous, as if it had crossed over from the continent.

It is a migratory bird, arriving among us in October, and departing in March; and as five or six are sometimes found roosting together, it is deemed probable that they migrate in flocks, more or less large. On one occasion, in Ireland, thirteen or fourteen were seen together. They breed in Northumberland, and probably other northern counties; in the Orkneys, in Dumfriesshire and other parts of Scotland: several of their nests have been found in Norfolk, and one, it is believed, in Suffolk.

They feed by day, especially in dull weather, and may 




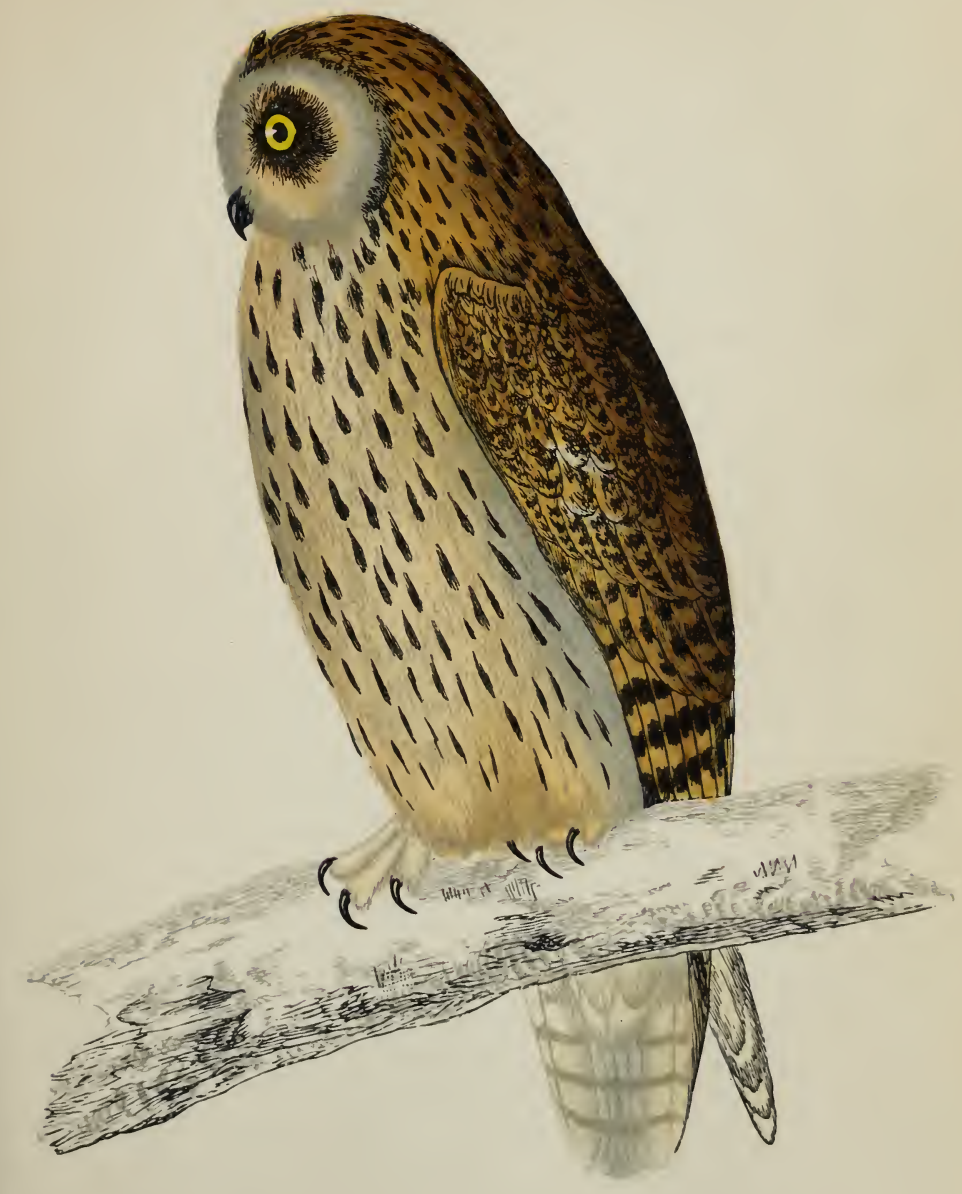



sumetimes be seen hawking over turnip fields, as well as in more wild districts, which they naturally prefer. When disturbed, they fly but a little way, and then alight again on the ground. If captured they defend themselves with much spirit, as does the Long-eared $\mathrm{Owl}$, but are in some degrec tameable; so much so as to take food from the hand. Onc kept by Montagu nerer drank during six months. They have been observed to retreat into rabbit-holes, at the entrance of which they had been stationed, after the manner of the Burrowing Owl of America.

On occasion, this species exhibits considerable powers of flight, and if teased by the pursuit of a Rook or other bird, easily surmounts it, and sometimes ascends to a great height, where it wheels about in circles. It flies much after the manner of a Sea-gull, and seems but very seldom to perch on trees.

Grouse, pigeons, plovers, larks, yellow-hammers, and other small birds, chickens, which it sometimes snaps up eren in the day-time from the barn door, rats, mice, reptiles, beetles and other insects, compose the prey of the Short-eared Owl. The legs of a purre were found in the stomach of one, and in another the remains of a bat. 'Generally speaking,' says Bishop Stanley, 'a more useful race of birds does not exist; since, with the exception of one or two of the larger and rarer species, their food consists entirely of vermin and insects, very prejudicial to our crops; and which, but for these nocturnal hunters, might do serious mischief. A striking instance of their utility occurred some years ago in the neighbourhood of Bridgewater, in Somersetshire, where during the summer such incredible numbers of mice overran the country as to destroy a large portion of regetation; and their ravages might have extended to an alarming degree, had it not been for a sudden assemblage of Owls, which resorted from all parts to prey upon them. Short-eared Owls, to the number of twenty-eight, have been counted in a single field, collected together, no doubt, by swarms of mice which in a favourable season had been bred there.'

The note is said, by Meyer, to be soft and pleasing, and to resemble the words 'kiou, kiou.' If alarmed for their young, they utter a shrill cry, and make, as also at other times, a snapping noise with their bills. The motion is so quick in doing this, that it is with difficulty the opening and shutting of the bill can be observed. 
The nest, which is built on the ground among long grass, heather, rushes, or fern, is composed of moss, hay, or grass, or even formed by a mere hollow in the earth. The young have been found seated on the ground near the nest before they were able to fly.

The eggs, which are white, are from three to five in number.

The whole plumage of these birds is very soft. Male; weight, about eleven ounces; length, one foot two to one foot three inches; bill, bluish or brownish black, and partly concealed by the plumage; cere, the same, the feathers about it also white with black shafts. Iris, yellow, with a tinge of red, surrounded by a ring of brownish black passing into white, and broadest behind; the feathers of the wreath which encircles the face are striped with light ferruginous and black, the latter predominating near the ears. The head dusky, the feathers edged with light ferruginous. The crown is furnished with two tufts or 'soi-disant' ears, but which in this species are not very conspicuous, and are chiefly set up when the bird is asleep or in a quiescent state. Bewick says that if frightened, the tufts are depressed, but the fact is that their then appearance is rather caused by all the feathers of the head being raised, so as nearly to hide the former. The tufts, which are placed near together, are composed of three or four feathers not much longer than the other feathers of the head, the longest being less than an inch in length; they are dusky on the outer webs and yellowish white on the inner. Neck, nape, chin, and throat, pale buff, with oblong dark brown streaks; breast, pale buff, sometimes darker, streaked with dark brown, wider above and narrower lower down on the shafts of the feathers, which are edged with yellowish. Back, dusky, the feathers edged with light ferruginous.

The wings, long and broad, and expand to the width of about three feet, or a little more; underneath they are yellowish white, the dark bars on the inner webs shewing through: they reach about an inch beyond the tail. Greater and lesser wing coverts, mottled with dark dusky and ferruginous, some of them spotted with yellowish white; primaries, very broad, yellowish salmon-colour, greyish towards the tips, white at the base of the outer webs: the second is the longest, the third nearly as long, the fourth a little shorter than the first; some of the quills are strongly serrated on 
the outer edge; the two or three first have one or two dusky bars, the next two or three, and the rest two, three, or four, on the outer webs; and all have one irregular bar, or part of one, on the inner-the bars are only on the outer half of the quills. Secondaries also broad, dusky buff, spotted with dull white, forming irregular bars; tertiaries, dusky buff; larger and lesser under wing coverts, as the wings; underneath, the feathers edged with brown, with a few brown spots.

Tail, rather short, buff, with four or five broad bands of dusky brown on the six middle feathers; the two centre ones spotted with dusky on the interstices; the bars on the outer feathers are fewer and imperfect, and the yellow on the outside feathers is shaded off to whitish; those have only two irregular brown bars on the inner webs; the tip yellowish white. Tail coverts, yellowish brown, faintly edged with a darker shade; under tail coverts, white. Legs, feathered, pale buff, short and thick; the third and fourth toes are united at the base by a short web; the first is the shortest, and has an extensive lateral motion, the third is the longest, the second and fourth nearly equal. Toes, the same, the feathers assuming a hairy appearance. Claws, much hooked, blackish grey, the middle one grooved beneath, with a sharp inner edge.

Female; length, about one foot four inches; the breast is rather deeper tinted than in the male, and the streaks broader. The back is rather lighter than in the male. The wings expand to the width of three feet one or two inches. 


\title{
LONG-EARED OWL.
}

\author{
LONG-HORNED OWL.
}

Strix otus,

Otus vulgaris,
LinNaUs. LATHAM

Fleming. Selby.

Strix-Some species of 0 wl.

Oûs. (plural ota)-An ear

As wisdom is certainly both more to be acquired and more to be considered to exist as the consequence of hearing, than of any other of the senses, the 'ears' of this species may have been the procuring a cause of the agnomen of the 'Bird of wisdom' attaching to its kind. It might, however, possibly be objected to this theory, that if it were correct, the ass should be deemed the wisest of animals.

The Long-eared Owl is plentiful in many countries of all four quarters of the globe. In Europe it occurs in Denmark, Russia, Sweden, Norway, France, Italy, Turkey, and Spain. In this country it is generally distributed, though nowhere numerous. In the fir woods, north-east of York, it is to be commonly met with. It is also a resident in Ireland and Scotland.

This Owl is not only a nocturnal, but occasionally, and and even in bright sunshine, a diurnal feeder: for the most part, however, it keeps quiet by day. It is readily tamed, and affords much amusement by the many grotesque attitudes it assumes, to which its ears and eyes give piquancy. It may often be detected with a small orifice left through which it is peeping when its eyes would seem to be shut; and it has the singular faculty of being able to close one eye while the other is not shut; so that it may appear to be 'wide awake' on one side, while apparently asleep on the other, or, if asleep, may be so literally 'with one eye open.' The ears are raised by any excitement; at other times they are depressed. If attacked, 




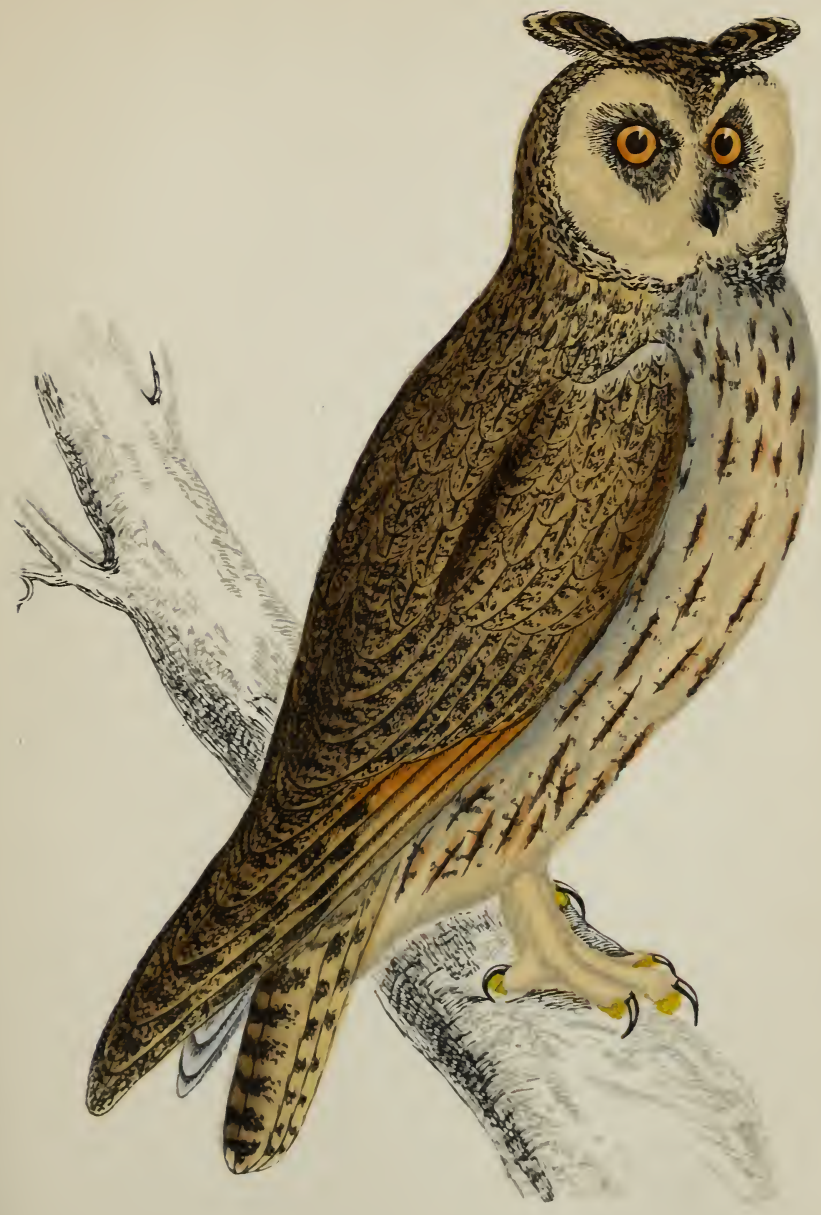



it makes a vigorous defence, throwing itself on its back, striking with its claws, and hissing and snapping with its bill. If provoked only, it merely makes a querulous noise. A friend of Mr. Thompson's, of Belfast, kept this and the preceding species instead of cats, and found them more effective as destroyers of rats and mice. They were, he says, 'very fond of having their ears rubbed,'

The food of this Owl consists of leverets, rabbits, rats, mice, moles, sparrows, snipes, chaffinches, blackbirds, linnets, goldfinches, and other small birds, which it is said to surprise when at roost, as also of beetles and other insects. It seizes its prey with its bill, with which it carries it if not large, but if otherwise transfers it to its foot.

Meyer says that the note is described by the word 'hook.'

Nidification commences early in March.

Other birds' nests, such as crows, magpies, and ringdoves, are generally, if not always, fitted up by the one before us as its domicile, by flattening them and lining them with a few feathers or a little wool. It sometimes even locates itself in that of a squirrel, and is not deterred by its not being far from the ground. Trees give it its 'locus standi,' evergreens, such as spruce, Scotch, and other firs, holly, and ivy, seeming to be preferred, especially in large woods. Ivy-covered rocks, and even the ground it also nestles on. It appears to be thought by some that there is a difference of eight or ten days in the laying of each egg, which are severally sat on in the intervals, causing a corresponding difference in the time of the young being hatched. 'The Long-horned Owl,' says Mudie, 'generally takes possession of the deserted nest of some other bird, such as one of the crow tribe, which nestle earlier, and thus have their brood out of the nest by the time that the Owl lays.' The Long-eared Owl, be it remembered, lays in March, and though I think that $\mathrm{Mr}$. Macgillivray is rather too severe upon Mudie, whose work is actually described by Mr. Neville Wood, as one of 'the two best which have yet appeared!' yet I cannot forbear asking here 'at what time does Rook-shooting commence?' If the young Rooks have fled before March, they must have had but a cold berth of it in February! Such an imagination as this reminds me of a somewhat corresponding mistake developed in an illustrated London paper. 'Our own correspondent,' 'on the spot' I suppose, was describing the circumstance of Her Majesty's witnessing the process of 'shearing' in the Highlands 
of Scotland, and a veritable engraving duly chronicled the barbarous despoiling of sheep of their fleeces in the month of October; and in that part of the Kingdom too! The writer was not aware that the term 'shearing' applied in the north of England to corn, as well as to sheep, and had as little thought for the unfortunate animals, as Mudie for the wretched Rooks.

The eggs, which are of a round shape, and white, are generally two in number, but sometimes three or four, and some writers say five, are laid about the end of March or the beginning of April, by the latter end of which the young are hatched.

'For the first month,' says Mr. Selby, 'they take up their abode in some adjoining tree; and for many subsequent days, indeed for weeks, may be heard after sunset uttering a plaintive call for food, during which time the parent birds are diligently employed in hawking for prey.'

These birds vary considerably in the depth and tone of their markings. Male; weight, nine or ten ounces; length, from one foot two to one foot three inches; bill, dull black-a streak of dark brown extends from it to the eye. Cere, flesh-coloured, hid by the feathers of the wreath, which are light brown on each outer side, with a half-circular boundary line of darker brown; on the inner side, dusky at the base, and white towards the tips. Iris, orange yellow, the radiated circle round the eye is cream-colour, faintly tinged with orange; the bristly feathers between the eyes and the bill are black at the base and white at the tips, the shafts black. Head, yellowish brown, mottled with darker and white. The tufts, which are formed of from seven or eight to twelve feathers, an inch and a half or more in length, are brownish black in the middle, and edged with white, light, or rufous, or yellowish brown-the hind ones are the shortest; the face is ferruginous, speckled with black and rufous, and surrounded in one of my specimens with part of a circle of white on the lower side. Neck and nape, light yellowish brown, much speckled and streaked with brownish black, dusky, ash grey, rufous, or white-the whole elegantly blended. Chin, throat, and breast, dark greyish white or creamcoloured, mixed with light or rufous brown, and streaked with dark brown, the shafts black; back, as the neck.

The wings, when closed, reach a little beyond the end of the tail, and expand to the width of three feet, and from that to three feet two inches. Greater and lesser wing coverts, as the neck; primaries, light brown or salmon-colour, barred 
and mottled towards their base with darker, tawny, or brown, and clouded with reddish grey, and brown at the tips: the second feather is the longest, the first and fourth equal, the third about half an inch shorter. Secondaries and tertiaries, barred more finely with tawny and dull black, and mottled; larger and lesser under wing coverts, light brownish yellow, with a spot of black at the base of the primaries. Tail, barred and speckled irregularly on the middle feathers, and decidedly on the outer with dusky and cinereous brown, yellowish or reddish orange, or dull white. It is square in shape, rather short, and composed of twelve broad rounded feathers; underneath greyish white, crossed with narrow bars of dusky brown. Under tail coverts, light brown, verging to white; legs, feathered with light brown or buff feathers. Toes, the same, except the ends of the two front ones, the third and fourth connected a : the base by a short web; the first is capable of extended sidemotion, the third is the longest, the second and fourth nearly equal. Claws, dull black, inclining to pink at the base, they are rather long, much curved, and sharp.

Female; length, one foot two to one foot four inches; the wreath is lighter, and the back has more greyish white than in the male: the older the birds the more grey. The wings expand to the width of from three feet two to three feet four inches.

The young are at first covered with white down, which next turns to yellowish, with which brown becomes gradually interspersed. At first the bars on the wings and tail are more distinct, and the streaks broader and darker, as indeed is th: whole plumage than in the adult birds. 


\section{EAGLE OWL.}

GREAT OWL. GREAT-EARED OWL. GREAT-HORNED OWL.

Strix Bubo, Bubo maximus,
Linneter. Montagu.

Selby. Gould.

\section{Strix-Some kind of Owl. Bubo-The Latin name of some} kind of Owl.

'What eyes he has!' in the words of the worthy gentleman recorded in Mr. Scropes' 'Days and nights of salmon fishing,' who trolled for a day in the vain attempt to catch a wooden pike stuck at the bottom of a pond; and who declared to the host, who inquired if he had caught it for dinner, that though he had not succeeded in doing so yet, that it had 'run at him several times!'

The Eagle Owl, as may be inferred from its name, bas much of the character and appearance of the former birdthe Owl in fact is merged in the Eagle.

The stronghold of this fine bird appears to be the north of Europe, but it also occurs in many of the Pennine ranges of the south. It inhabits Denmark, Norway, Sweden, Russia, Lapland, Germany, Switzerland, Astrachan, Turkey, Hungary, France, and Spain. It also occurs in China, and other parts of Asia; Meyer says that it is found in Africa, and in North and South America; but though Wilson seems to take it for granted that Pennant was right in considering the Virginian Horned Owl of the latter continent only a variety of the species before us; yet if that is the one meant by Meyer, I think it is distinct, judging from Wilson's own description.

In Yorkshire, a specimen of this bird was shot in the month of March, 1845, in the woods of Clifton Castle, near Bedale, one of the most beautifully-situated residences in the kingdom, the seat of Timothy Hutton, Esq., late High-Sheriff; another 




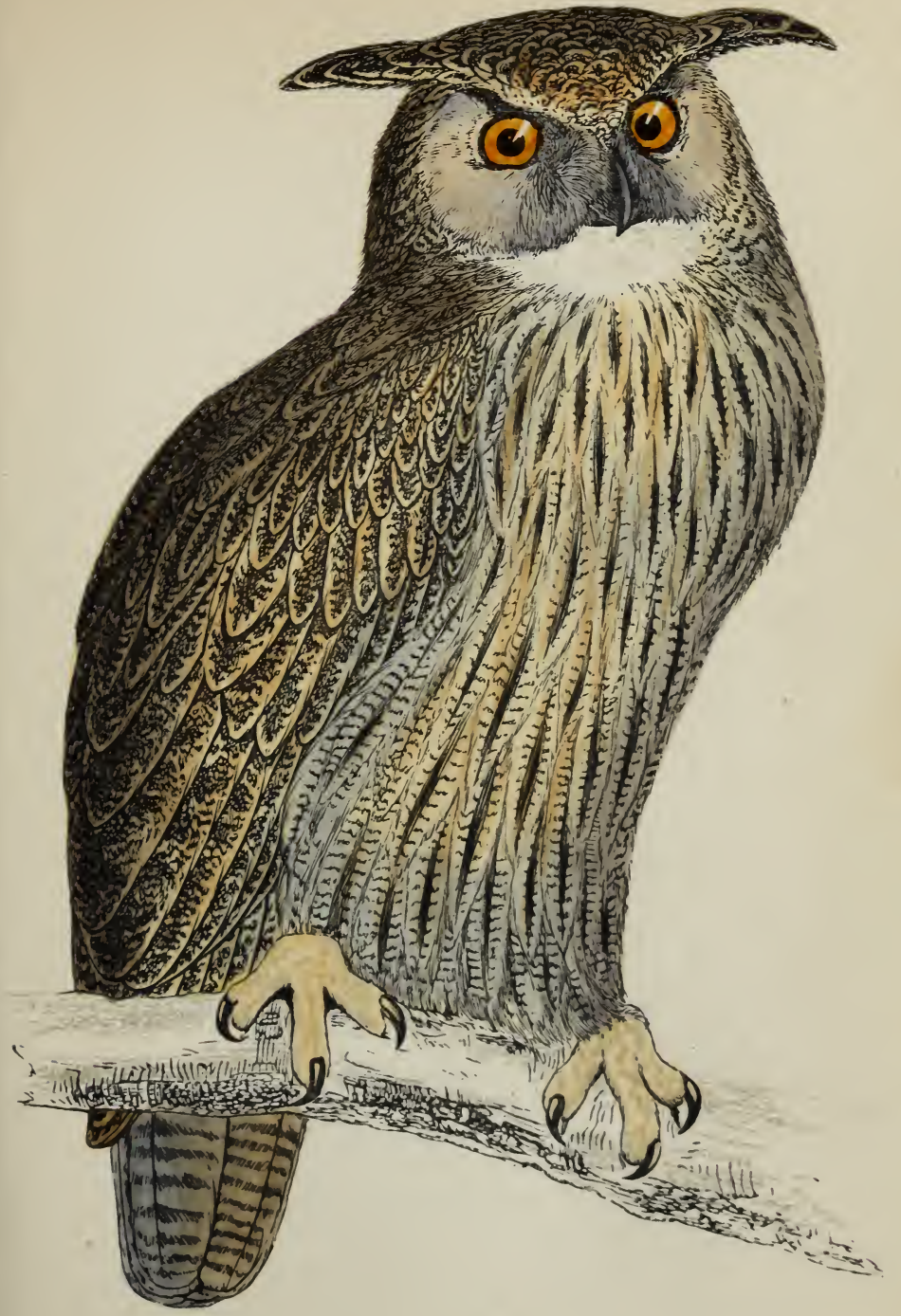



at Horton, near Bradford, about the year 1524; and a third was caught in a wood near Harrogate, in the summer of 1832. One was taken in the year 1848, as I am informed by the Rev. R. P. Alington, in the parish of Stainton Le Vale, Lincolnshire. Others have been met with in Kent, Sussex, Devonshire, Suffolk, and Durham; several near Melbourne, in Derbyshire; one at Shardlow, in 1828; one at Hampstead, near London, on the 3rd. of Norember, 1845, which had been previously wounded in the wing. In Ireland, four specimens visited the county of Donegal, after a great snow-storm from the north-east. In the Orkney Islands it is considered to be a permanent resident.

'Owls have been noticed,' says Bishop Stanley, 'for an extraordinary attachment to their young; whether, however, it exceeds that of other birds or animals may be very difficult to say, but they will certainly visit and feed them long after they have been separated from the nest. Some young Owls which had been so far tamed as to take food from the hand, were observed to lose all their familiarity on being hung out during the night, in consequence of renewed visits from the supposed parent birds, who fed them with as much care and attention as if they had been with them without interruption. Another instance in point was witnessed by a Swedish gentleman, who resided several years on a farm near a steep mountain, on the summit of which two Eagle Owls had built their nest. One day in the month of July, a young bird having quitted the nest was caught by the servants. This bird was, considering the season of the year, well feathered, but the down appeared here and there between those feathers which had not yet attained their full growth. After it was caught it was shut up in a large hen-coop, when to his surprise, on the following morning, a fine young partridge was found lying dead before the door of the coop. It was immediately concluded that this provision had been brought there by the old Owls, which no doubt had been making search in the night-time for their lost young one; and such was indeed the fact, for night after night, for fourteen days, was this same mark of attention repeated. The game which the old ones carried to it consisted chiefly of young partridges; for the most part newly killed, but sometimes a little spoiled. It was supposed that the spoiled flesh had already been some time in the nest of the old Owls, and that they had brought it merely because they had no better 
provision at the time. The gentleman and his servant watched several nights in order that they might observe, through a window, when and how this supply was brought, but in vain; for it appeared that the Owls, which are very quick-sighted, had discovered the moment when the window was not watched, as food was found to be placed before the coop on these very nights. In the month of August, the attention on the part of the old birds ceased; but it should be observed that this was about the usual period when all birds of prey abandon their young to their own exertions, and usually drive them off to shift for themselves in distant haunts. It may be readily concluded, from this instance, how much game must be destroyed by a pair of these large Owls, during the time they rear their young.'

The Eagle Owl is easily reconciled to confinement; and in two instances has been known to breed in captivity. A pair of these birds, in the possession of Mr. Edward Fountaine, of Easton, near Norwich, formed a nest of straw in the corner of their cage: the first egg was laid on the 13th. of April, 1849; and two others about a week afterwards. Two young birds were hatched on the 19th. of May, and the third on the 22nd. Another which was kept in the Zoological Gardens, has also been known to lay an egg. In defence of this, it exhibited the most determined spirit; hissing and snapping with its bill, and ruffling all its feathers.

In moving on the ground, the action of this bird is by a series of jumps, aided by the wings: it does not walk.

The food of the Eagle Owl consists of even the larger animals, such as fawns and lambs; hares, rabbits, rats, mice, and moles; birds-capercali, pheasants, grouse, partridges, crows, rooks; as also snakes, lizards, frogs; and even insects and fish; all indeed seems to be fish that comes to its net. It pounces at its prey on the ground, and is said to destroy life with its claws alone. The smaller prey are swallowed whole, the larger are torn in pieces. 'From its lonely retreat in some deep forest glen,' says Linnæus Martin, 'some rift among hoary rocks, where it reposes in silence during the day, this winged marauder issues forth at night, intent upon its victims; its harsh dismal voice resounding at intervals through the gloomy solitude of a wild and savage scene.'

The note resembles the bark of a small dog, varied sometimes into a 'hout,' or 'hoo,' or 'poo-hoo,' accompanied by a snapping of the bill, and hissing. The female has in addition 
a screech in the breeding season. The young utter a continual hissing and piping noise.

Nidification commences the latter end of March-only one brood is produced in the year. The female sits about five weeks. Incubation begins in April, and the young are hatched in May. The nest is very large, and is placed on rocks or old ruins, amid the desolate sterility of the bleak hill, or the wild unsheltered mountain. It is composed of branches and sticks, and is lined with leaves and straw. Occasionally a hollow in the bare earth answers the purpose. The same eyrie is frequently resorted to year after year.

The egg's are two or three in number, white or bluish white, and, like those of all the Owls, of a rotund form, and, as described by Meyer, of a rough chalky appearance.

Male; weight, about seven pounds; length, from about two feet to two feet two inches; bill, dull black, tinged with greyish blue, and paler at the base: it is nearly hid at the base by the feathers. Cere, dusky, concealed by the feathers; iris, bright orange, it is fringed around the margin with short bristly feathers. The feathers of the head are mottled, reddish brown or yellow, streaked and spotted, especially down the middle, with multitudinous dark brown specks and spots: the centre of each feather is dark, which widens at the tips, and is shaded off and mottled at the sides. The tufts are formed of from seven or eight to twelve dark feathers, barred with light brown on the inner webs. They are about two inches and a half in length beyond the surface of the rest of the plumage. The face light brown, speckled with greyish black and white beneath; the ruff is indistinct and incomplete, extending only from a little above the ear to the chin. Neck, as the head, but more tinged with red, and some of the feathers only spotted; nape, the same; chin, white, a band of mottled and barred feathers - $;$ continuation of the ruff, between it and the throat, which is also white, spotted with black. Breast, above, light brown, ferruginous yellow, and greyish, streaked with dark brown on the lower part, and towards the sides irregularly and numerously barred on each feather with the same, the shafts being black; back, as the head.

The wings are very large, broad and rounded; they expand to the width of about five feet one inch; underneath they are greyish yellow, barred and dotted with dusky brown: greater and lesser wing coverts, as the back. Primaries, as the head, but barred transversely with brownish black, the 
intervals yellowish red margined with yellowish brown; the outer webs spotted and waved with brown, the inner nearly plain; the tips dark brown mingled with grey; the third is the longest, the fourth nearly as long, the first an inch and a half shorter than the second. Secondaries, tertiaries, and larger and lesser under wing coverts, much barred indistinctly with dark brown, and the shafts dark. Tail, as the primaries, but lighter, the bars on the inner webs being narrower; underneath it is barred still more narrowly, and with a still lighter shade: it consists of twelve broad rounded feathers. Tail coverts, as the back; under tail coverts, as the lower part of the breast; legs, feathered and the same; toes, the same; claws, long, much curved, and in colour as the bill.

The female is a little larger and darker plumaged than the male. Weight, between seven and eight pounds; length, about two feet four inches; bill, bluish grey at the base, blackish grey at the tip; chin, white; throat, white; claws, as the bill.

The young are at first covered with white down, which at about the end of a month becomes brownish grey, and in another week or two the feathers begin to shew themselves. The bill is black; iris, yellow; the breast becomes rusty red, striped with dusky. Wings, dark, with reddish brown spots; tail, dark, with round red spots; legs and toes, reddish brown. 




\section{SCOPS-EARED OWL.}

LITTLE-HORNED OWL.

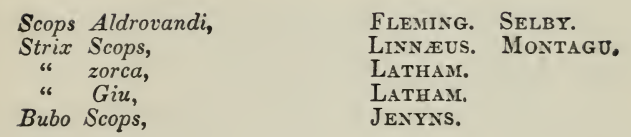

Scops-The Greek name of some kind of 0wl. Aldrovandi-Of Aldrovandus.

THIs little $\mathrm{Owl}$ is a native of the temperate parts of each of the four quarters of the globe. In Europe, it occurs plentifully in France, Italy, Germany, Austria, Switzerland, and other countries. In Holland it is rare.

In Yorkshire, a specimen of this kind was recorded by $\mathrm{J}$. S. Foljambe, Esq., to have formerly occurred. Another was shot near Wetherby, in the spring of 1805 ; another near York; one near Driffield, in 1839; and one at Boynton, Sir George Strickland's, near Bridlington, in July, 1S32; one at Bossal, then the residence of Captain Beaumont, near York; one near Eshton Hall; and four, two old birds and two young ones, at Ripley, Sir William Ingleby's, which were for a fortnight nailed up to a house. Another is said to have been shot at Womersley, one of the seats of Lord Hawke; one in Sussex, at Shillinglee, the seat of Lord Winterton; one near Brill, in Buckinghamshire, in 1833; one in the Island of Tresco, one of the Scilly Islands, in April, $1 S 47$. Another was caught near London; and one in Worcestershire. near Fladbury; and two were shot near Audley End, in Essex, the seat of Lord Braybrooke. It is said to have bred in Castle Eden Dene, in the county of Durham, and does so near the River Oykel, in Sutherlandshiro. 
In Ireland, two specimens have been obtained, one in the month of July, at Loughcrew, in the county of Meath, the seat of J. W. Lennox Naper, Esq.; and another in April, 1847, near Kilmore, in the county of Wexford.

This species inhabits gardens and plantations even in the neighbourhood of towns.

During the day-time they lie 'perdu' in the holes of trees, or leafy recesses, from whence they emerge in the evening to seek their prey. If taken young from the nest they are easily trmed.

Their flight, according to Meyer, is soft and wavering, but tolerably quick.

Their food consists of mice, frogs, small birds, grasshoppers, cockchaffers, moths, and other insects, and worms: with the latter kinds the young birds are fed.

The note, which is very loud, and resembles the words 'kew, kew,' is said to be uttered 'as regular as the ticking of a pendulum,' at intervals of about half a minute.

The nest is generally placed in the hole of a tree or a rock, as also in heather. Selby says that it constructs no nest.

The eggs are white, and from two to four or fire, or, according to Selby, as many as six in number.

These birds vary much in colour, from dark brown of various shades to grey. Male; length, about seven inches and a half; bill, dusky, black at the tip; iris, yellow; the tufts on the head are short and indistinct; the feathers, which are six or eight, to twelve in number, are dark in the centre; the ruff, which is also inconspicuous, is yellowish white at the base, and tipped with black; the face, grey, delicately pencilled with brown. Crown, streaked with dark brown on a pale brown ground, forming a central band between the tufts; breast, dull yellow and grey, mottled with brown in the most beautiful manner; some of the feathers with squareshaped dusky spots, and wared with narrow lines of the same. Back, rufous brown and grey; the former the predominating colour; the whole streaked, barred, and mottled with black.

The wings extend a little beyond the end of the tail, and expand to the width of about one foot eight or nine inches; greater and lesser wing coverts, as the back, with a conspicuous mark of yellowish white, the feathers edged and tipped with dark brown; primaries, barred with yellowish, or greyish, or 
rufous white and brown on the inner webs; and on the outer webs with alternate bars of white and speckled brown, the former shaded at the edges with the latter. The third is the longest, the second nearly as long, the fourth the next, the first intermediate between the fifth and the sixth. The secondaries have an oval spot of white on the outer webs, which together form an interrupted bar across; tail, slightly rounded, and barred alternately with a lighter and a darker mottled space, and one of yellowish or reddish white; underneath it is, as are the under tail coverts, greyish white, mottled and barred with brown. The legs, which are feathered, are dark yellowish or rufous white, streaked and speckled with brown on the centre of the feathers; (Mudie says that ther are bare of feathers, from which fact he supposed that this species belongs to warmer climes;) toes, bluish yellow, not feathered, but covered with scales: the outer one is capable of being turned backwards; claws, horn-colour.

The female does not differ much in plumage from the male; length, eight inches and a half.

The yourg are said to be at first grey, and the iris light yellow. 


\section{SNOTVY OTVI.}

Strix nyctea, Surnia nyctea, Noctua nyctea,
Montagu. Bewior.

Selby. Gouzd. JENYNS.

Strix-Some species of Owl. from Nix-Snow.

Nyctea-An adjective

THe Snowy Owl may derive its name either from the snowwhite colour of its plumage when fully adult, or from the snow-covered regions which are its natural residence.

It inhabits the arctic parts of Europe, Asia, and America; from these it sometimes advances more or less far towards the south, but the farther the seldomer. In Europe it occurs in abundance in Kamtschatka and Siberia; in considerable numbers in Russia, Lapland, Norway, and Sweden; as also in Iceland and Greenland; occasionally in Prussia, Poland, Germany, and Switzerland; and once appeared in Holland, in the winter of 1802 .

This splendid Owl has been one of the 'oldest inhabitants' of the Orkney and Shetland Islands, and specimens have been procured there; but like that well-known character it is now fast becoming apochryphal. Beauty in Owls, as well as in human beings is a dangerous possession, and often entails damage and destruction. One was killed on the Isle of Unst, in the month of August or September, 1812: old birds and young together, have been regularly seen in that island, and also on Yell, in which they have been accustomed to breed. One in Orkney, which had been áriven there in a storm from the norti-west, at the end of March, in 1835. In Yorkshire one was shot near Selby, on the 13th. of February, 1837; and another was seen in company with it at the same time. Another vas shot at Elsdon, in Northumberland, in December, 1822; and two near Rothbury, in the same county, at the end of January, 1823, during a severe 




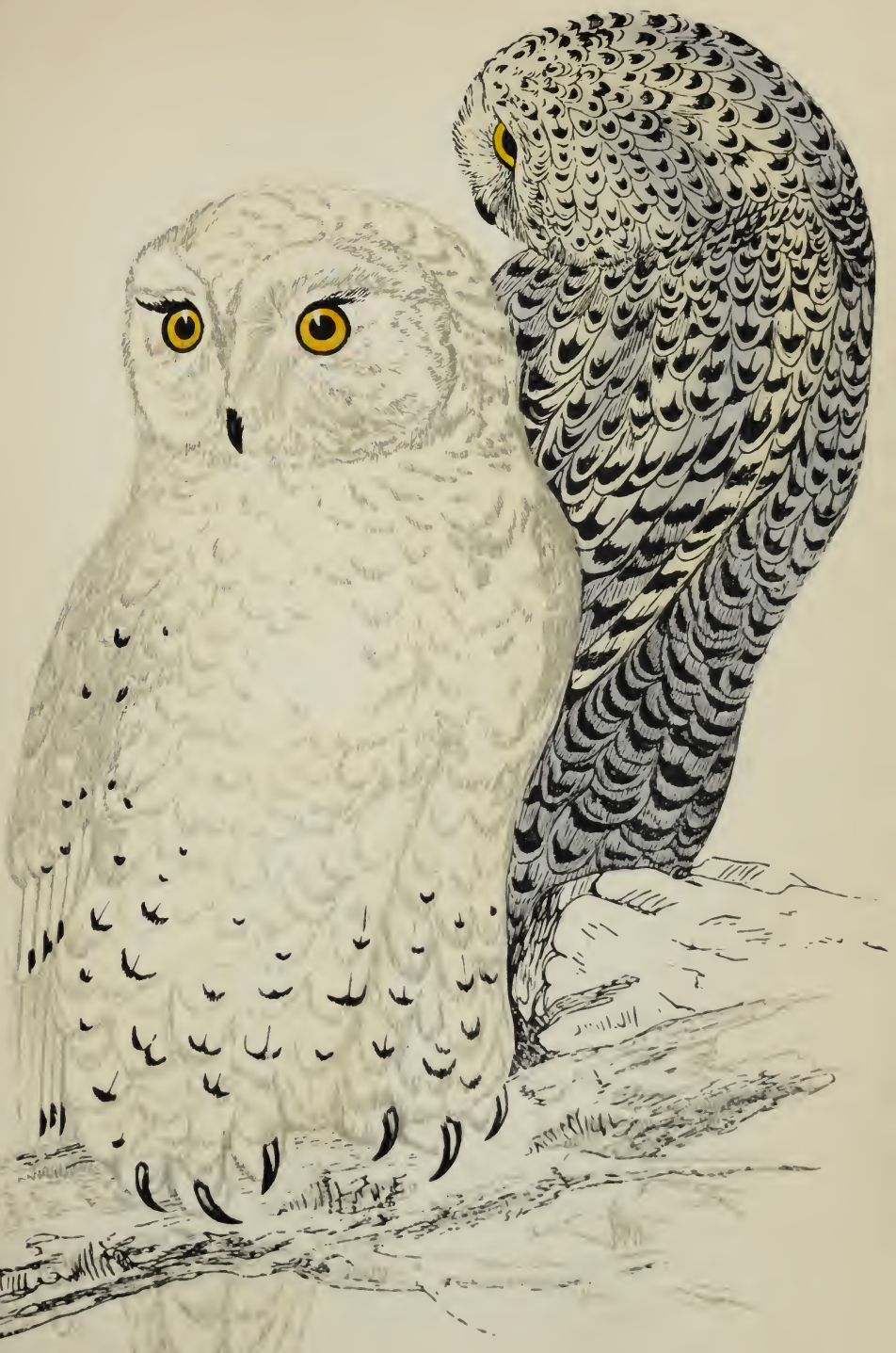



snow-storm; one in Norfolk, in 1814, and one in 1820; third at Beeston, near Cromer, on the 22nd. of January, and a fourth at St. Faith's, about the end of February, 1850. A fifth had beels seen at Swannington, the middle of the preceding year; one was killed at Frinsted, in Kent, in 1844; one at Langton, near Blandford, in Dorsetshire; and one, as I am informed by Mr. R. A. Julian, Junior, was knocked down with a stick by a boatman, on the bank of the River Tamar, near St. Germans, in Cornwall, in December, 1838. One at St. Andrews, in Suffolk, on the 19th. of February, 1847. 'It was shot from the stump of a pollard elm, whence it had been seen to dart down into the field, and then to return to its perch.' It had previously been seen, for there is no reasonable doubt but that it was the same bird, at Brooke, in the county of Norfolk. One was seen near Melbourne, in Derbyshire, on the 20th. of May, 1841; and one obtained near Caithness, in January, 1850, in stormy snowy weather. It was shot with a duck in its talons, which it had carried of from a sportsman by whom the latter had just been killed, and who had previously fired without success to endearour to make it drop.it. In Sutherlandshire these birds are not very unfrequently driven on the north and north-east coasts, after gales from that quarter.

In Ireland specimens have occurred in the years 1812 and 1827: also in 1835, about the 20th. of March, one was shot near Portglenone, in the county of Antrim; on the 21st. another was seen in the same neighbourhood. One was shot in the county of Mayo, also in the month of March; and another in the month of April, in the county of Longford, where another had been procured about the year 1835; one on the 2nd. of December, 1837, on the Scrabo Mountain, in Downshire; and one near Killibegs, in the county of Donegal, in November or December, 1837.

Large flights of these birds were observed on the coast of Labrador, in the month of November, 1S38, on their migration. They accompanied the ship for fourteen days, and frequently alighted on the yards. Four were captured and brought to Belfast by the captain. They have been similarly observed in two different years on the coast of Newfoundland; each time in the month of September.

They hunt their prey by day, occasionally all day long, and even in the brightest sunshine, on which account I cannot think that their being seen sometimes perched under the 
shelter of projecting stones, can be, as some have thought, for the purpose of avoiding a strong glare of light: they seem to have no dread of a 'coup de soleil.' Though the frozen regions are the home of these birds, they appear to be able to bear heat without inconvenience. They are of a shy nature, but will sometimes approach a sportsman, in anticipation of his furnishing them with food, and are not deterred even by the sound of the gun, but rather seem to consider it as a dinner bell, whose summons calls them to a meal. They frequent open snow-covered districts, and also mountains and wooded ones, and perch upon a stone or other eminence, from whence they can keep a look-out. Their similarity of colour to the snow may possibly give then some advantage, as the rifle green to the rifle brigade, at least so it has been suggested. If put up they fly a little way, and then, generally, light again. They are said, when fat, to be good eating. When they begin to prowl about, they are followed, like the Hawks, by Rooks and other birds. Instances are reported to have occurred when they have been surprised asleep, and caught napping. When taken young they may be partially tamed.

In flight these birds are very active, resembling in this respect the Hawks more than the Owls, though the airy lightness of the latter on the wing is by no means lost. Mr. Thompson, of Belfast, has well remarked that rare birds that are met with wandering about the country, are, for the most part, young ones, and the reason doubtless is that touched upon by me in treating of the Kestrel-the parent birds retain possession of their own native haunts-the young are compelled to rove.

The food of this species consists of hares, rabbits, rats, lemmings, squirrels, and other animals; as also of capereali, ptarmigans, ducks, partridges, sandpipers, and any others of the smaller birds. Mr. Mudie's theory is that the hares and ptarmigans would be destroyed by famine and cold in the winter, if they were not devoured by the Showy Owis, so that it would appear that they have to feel indebted to the latter for putting them out of the way of future misery. They prowi for prey near the ground, and strike with their feet. They are said in case of necessity to feed on carrion. Small prey such as young rabbits, and small birds, they occasionally at all events swallow whole. They also feed on fish, which they dexterously skim from the surface of the water, or sometimes 
ike other fishermen, watch for from the brink of a stream. Their mode, however, of angling, is in this case, as described by Audubon, a very peculiar one: they approach the brink of a rock, lay down flat upon it close to the water, and when a fish comes within reach, strike at it with their talons, and secure it with this natural kind of gaff.

The note is said sometimes to resemble the cry of a person in danger, but ordinarily it seems to resemble that of the Cuckoo, but is shorter and quicker. They also hiss and fuff like a catu, and make a snapping noise with their bills, and sometimes croak like a frog.

The nest is made on the ground, or upon rocks, though sometimes, it is said, in trees, and is composed of branches.

The eggs are white, but by Veillot said to be spotted with black, and two, three, or four in number, of which only two are thought to be in general hatched.

Nale; weight, about three pounds or a little over; length; from one foot ten or eleven inches to two feet; bill, black; iris, bright yellow; bristly white feathers nearly hide the bill. The ruff round the head is scarcely apparent; it and the crown, reck, nape, chin, throat, breast, and back, are white in the fully adult bird, but spotted in less mature specimens as in the female, but the spots are not so dark. The wings extend to rather more than two thirds the length of the tail, and expand to about four feet nine inches; greater and lesser wing coverts, white. Primaries also white: the first is sometimes longer than the fifth, but often shorter; the second and fourth are nearly equal, and a little shorter than the third, which is the longest. Secondaries, tertiaries, larger and lesser under wing coverts, all white; tail, wedge-shaped; tail coverts, white. Legs, rough and completely covered with long hairy feathers, which almost conceal the claws; the toes are also coverea by the plumage. Claws, black, very long, and much curred, the inner and miadle ones grooved, the others round.

The female dces not often attain to the perfectly white plumage; the spots are at the end of each feather, and of a crescent shape on the breast, and more elongated on the back. Weight, abore three pounds; length, from two feet one or two, to two feet three inches; bill, black; iris, bright yellow; bristles as in the male. Head on the crown, thickly studded with round black srots; neck and nape, spotted with dark brown; chin, throat, and breast, white, spotted more or 
less with brown, and the sides somewhat barred; back, as the neck. The wings expand to the width of five feet two inches; greater and lesser wing coverts, as the back; primaries, white; barred with dark brown bars, two inches apart; secondaries and tertiaries, white, spotted with dark brown; larger and lesser under wing coverts, as the breast. Tail, white, banded with bars of broad brown spots; tail coverts, as the back. Legs and toes as in the male, but with a few spots; claws, black.

The young are at first covered with brown down, and have their first feathers also light brown. Their next plumage is similar to that of the female, only that they are much more spotted all over: in fact the abundance of spots is a sign of youth, as their absence is of age. 



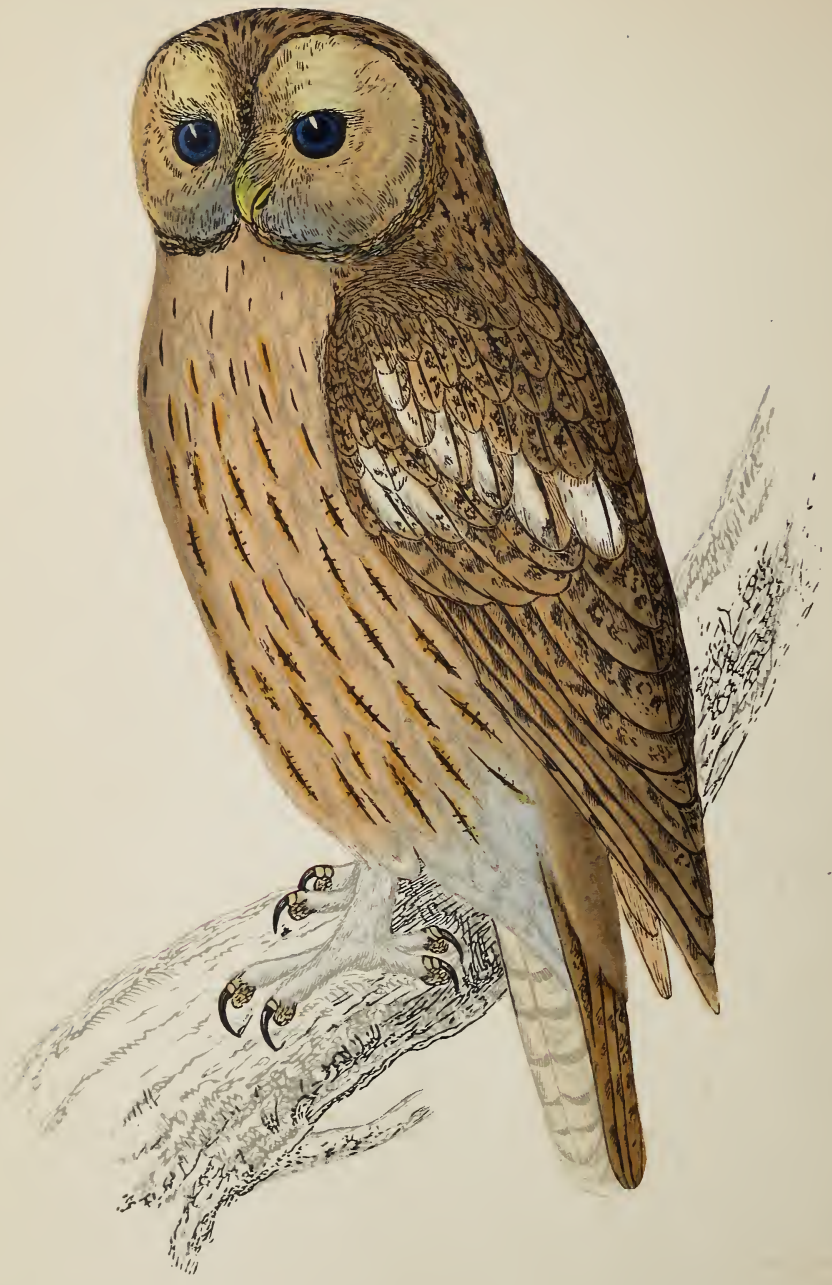






\section{TAWNY OWL.}

BROWX OWL.

Ulula stridula,

Strix stridula,

" aluco,

Syrnium aluco,
Selby.

Lisnats. Fleyixg.

LATHAM.

Jenyxs. TEMMUck.

Ulula.

Ululare-To howl like a wolf. Harsh-grating-creaking.

Stridula-

HERE is another victim of persecution! Were it not for the friendly shelter of the night, and the fostering care of some few friends, where is the Brown Owl that would be able to maintain a place among the 'feathered tribes' of England? Their 'passports' are invariably sent to them in the form of cartridge paper; a double-barrelled gun furnishes a ready, 'missive;' their 'conge' is given with a general 'discharge,' and the unoffending, harmless, nay, useful bird is ordered for ever to 'quit.' His family are not permitted to hold their own, but are themselves outlawed and proscribed; their dwelling is confiscated, a 'clearance' is effected; and if there be is wife and children, 'alack for woe!' They are carried into captivity. You have my pity, at all events, poor Brown Owl; and, believe me, I would that the expression of it might do you a kindness; but I have sad misgivings-you are a marked bird-they have given you a bad naine, and the proverb tells you the fatal consequence.

The Tawny Owl, or Brown Owl, is known in many countries of Europe-Lapland, Scandinavia, Russia, Spain, Italy, and others; as also in Asia Minor and Japan. It is a common species in England, but is more rare in Scotland, especially in the northern parts, and the Orkney Islands: two have been met with in the Queen's County, in Ireland. Wooded districts are its resort, and from these it only issues, voluntarily, at 
night, which, as with our antipodes, is its day. In the winter, when the trees ordinarily no longer afford it a covert, it secretes itself in old buildings, or the hollows of trees, or in evergreens, such as firs and holly, and in ivy.

If disturbed during the day-time, and frightened from its retreat, it flies about in a bewildered manner, the light doubtless being unnatural and uncongenial to it. It may easily, in this state, be overtaken and knocked down with sticks and stones. The twilight of morning and evening is the time to see it enjoying its fitful flight.

The following anecdote of a bird of this species is related by Mr. Couch, in his 'Illustrations of Instinct.' 'A Brown Owl had long been in the occupation of a convenient hole in a hollow tree; and in it for several years had rejoiced over its progeny, with hope of the pleasure to be enjoyed in excursions of hunting in their company; but through the persecutions of some persons on the farm, who had watched the bird's proceedings, this hope had been repeatedly disappointed by the plunder of the nest, at the time when the young ones were ready for flight. On the last occasion, an individual was ascending their retreat, to repeat the robbery, when the parent bird, aware of the danger, grasped her only young one in her claws, and bore it away, and never more was the nest placed in the same situation.' These birds are easily tamed, and become quite domestic. 'They are at first,' says Montagu, 'very shy, but soon become tame if fed by hand. If put out of doors within hearing of the parent birds, they retain their native shyness, as the old ones visit them at night, and supply them with ample provision.' Even if taken in the mature state they may be tamed without difficulty. They have never been known to drink.

The flight of the Brown Owl is rather heavy and slow, particularly at its first entering on the wing.

The food of this species consists of leverets, young rabbits, moles, rats, mice, and other small quadrupeds; birds of various kinds; frogs, beetles, and other insects, worms, and even fish.

The note resembles the syllables 'hoo-hoo-hoo,' and it also occasionally utters a harsh scream. I may here observe, in reference to the generic name prefixed to this species, that the name of the Owl is probably a corruption of the word 'howl.' Meyer describes the note as resembling a satirical laugh. 
Nidification commences in March. The nest, if it deserves the name, is formed of a few soft feathers, a few straws, or a little moss, sometimes merely of the decayed wood in the hollow of a tree in which it is placed; and has once been observed so low down that a person could see into it from the ground; occasionally it is built in rocks, sometimes, it is said, in barns or the like buildings, or even in the deserted nests of other birds, such as buzzards, crows, and magpies. The young are hatched in April: they continue to perch among the branches of trees in the neighbourhood of the nest before finally taking their leave of it, and are fed during this interval by the parent birds.

The eggs are white, and from two or three to four or five in number: the first is sat on as soon as laid, and the young are hatched in about three weeks: they are blind for some days, and their red eyelids look as if inflamed.

The ground colour of these birds varies very much; scarcely two individuals are met with precisely similar in their markings. Male; weight, between fifteen and sixteen ounces; length, one foot one to one foot three inches; bill, pale horn-colour, much hid by bristles; cere, flesh-coloured; iris, dark brown, nearly black, two irregular white stripes extend backwards over the eye. Head, large; crown, dark brown and grey, tinged with rufous; the bristly feathers of the face are greyish white, interspersed with black near the bill; the small rounded feathers of the wreath are black in the middle, edged, spotted, and barred with white and rufous; the grey prevails near the eyes, and brown near the ears; neck, dingy white, the feathers streaked with rufous brown, the shafts dusky, and zigzag lines or spots at the tips. The feathers of the nape are dark brown in the centre, edged with brownish grey, spotted with brown, and tinged with rufous; chin, brownish grey; throat and breast, as the neck, the lines on the lower part of the latter are indistinctly crossed; back, as the nape.

The wings expand to the width of from two feet eight inches to three feet: they do not reach to the middle of the tail; greater and lesser wing coverts, as the back, but more spotted with brown in waving lines, and with some white spots on the greater, forming obscure patehes; primaries, rufous yellow barred with dusky, white at the base; the fourth the longest in the wing, the fifth almost as long; underneath they are dull white, barred with pale brown; secondaries, the same, but the bars are narrower and more distinct tertiaries as the 
back. Greater and lesser under wing coverts, dull white, barred with pale brown; tail, pale rufous grey speckled with dark brown, and barred, but faintly, on the outer webs with the same: the two middle feathers are nearly plain, and rufous; the tip white; underneath it is dull white, barred with pale brown; tail coverts, as the back; under tail coverts, dull white barred with rufous brown, the shafts of the feathers brown; legs, almost entirely covered with yellowish white or grey feathers, spotted with brown; toes, dark yellow or flesh-coloured, and rough; claws, hom-coloured, with black tips, and not very much hooked.

The female chiefiy differs in size, and is less tawny, so that it was formerly thought to be a different species. Weight, nineteen ounces; length, one foot three to one foot five inches.

The wings expand to the width of three feet, and upwards.

The young are at first covered with grey down. The young female assumes a rufous tinge, the tail is scarcely barred, and the bars on the wings are narrower than in the adult birds. The young male resembles the female for the first two years. A variety with the parts light ash grey, which are usually brown, was met with in 1948 , at Pensax, near Worcester. it had previcusly been remarked in the nest. 



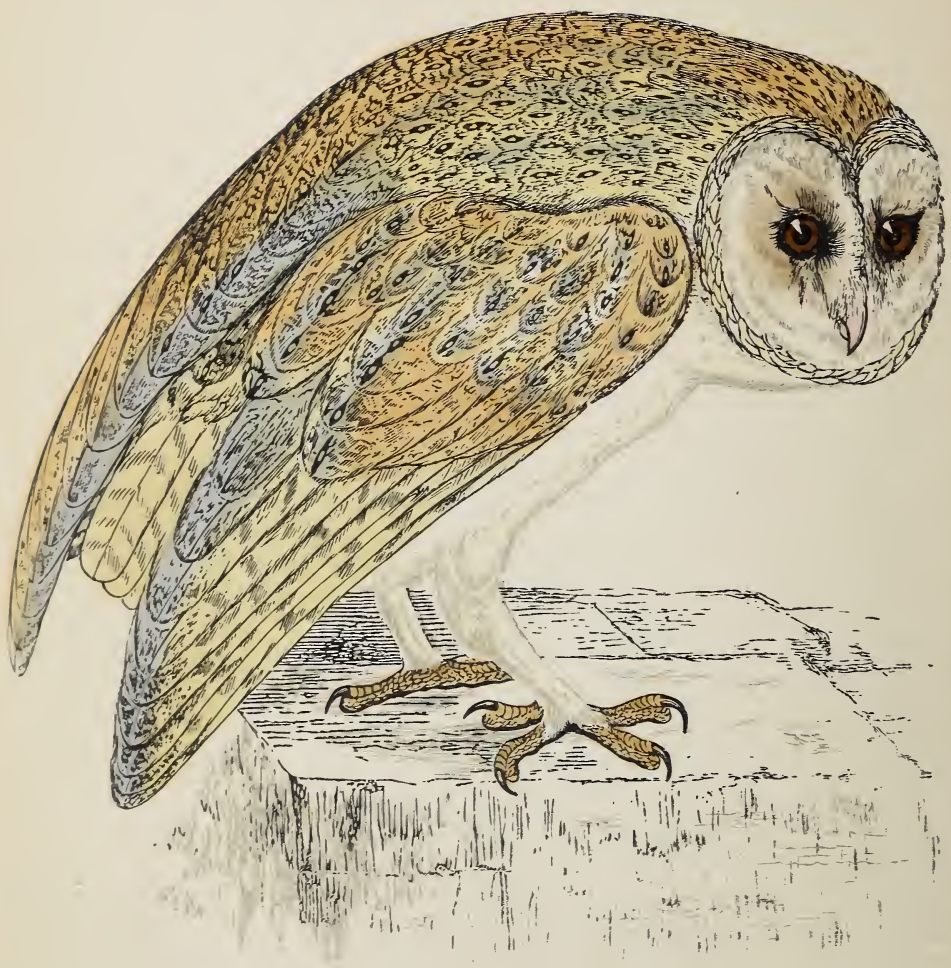

WHITE OWL. 




\title{
WHITE OWL.
}

\begin{abstract}
YELLOW OWL. BARY OWL. SCREECH OWL. GLLLI-HOWLET. HOWLET. MADGE OWL. CHURCH OWL. HISSING OWL.
\end{abstract}

DYLLUAY WEN, OF THE AYCIENT BRITISH.

\begin{abstract}
Strix flammea, Aluco flammeus, " minor,
\end{abstract}

Penvant. Montagu.

FLEMING.

Aldrovandus.

\begin{abstract}
Strix-Some species of Owl. $\quad$ Flammea-Of the colour of fire-yellow.
\end{abstract}

THIs bird, a 'high churchman,' is almost proverbially attached to the church, within whose sacred precincts it finds a sanctuary, as others have done in former ages, and in whose 'ivy-mantled tower' it securely rears its brood. The very last specimen but one that I have seen was a young bird perched on the exact centre of the 'reredos' in Charing Church, Kent, where its ancestors for many generations have been preserved by the careful protection of the worthy curate, the Rev. J. Dix, against the machinations of mischievous boys, and the 'organ' of destructiveness of those who ought to know better.

The White $\mathrm{Owl}$ is dispersed more or less generally, according to naturalists, all over the earth: it is however the least numerous in the colder districts. Northward it occurs as far as Denmark, and Sweden to the south, but is as yet unrecorded as an inhabitant of Norway. Its range extends southward to the Cape of Good Hope; eastward to India and New Holland, as is said; and westward, if indeed the species be the same, to the United States. Madeira is one of its habitats: in Tartary it is said to be very abundant. It occurs throughout England, and that as the most plentiful of its tribe; in Ireland 
it is likewise the most common of the Owls; in Scotland it is less numerous, particularly towards the north-west; and in the Orkney Islands still more unfrequent.

This bird is a perennial resident with us, and if unmolested frequents the same haunts for a succession of years. It displays considerable affection for its young. Mr. Thomas Prater, of Bicester, relates in the 'Zoologist,' that an old ivy-clad tree having been blown down at Chesterton, Oxfordshire, a family of White Owls was dislodged by its fall: the parent bird placed the young ones under the tree, and was not deterred from her maternal duties by the frequent visits of the keeper on his rounds; but one morning as he was turning away from looking at them, flew at him with great fury, and buffeted him about the head.

As a proof, among the many others which have been, and might be given, of the influence of protection and kindness upon wild birds, I may here mention, my informant being Mr. Charles Muskett, of Norwich, that a pair of this species, which lived in a barn near his father's residence, were so fearless that they would remain there while the men were thrashing, and if a mouse was dislodged by a sheaf being removed, would pounce down upon it before them, without minding their presence. They not very unfrequently become of their own accord halfdomesticated, from frequenting the vicinage of man without molestation, where their good services are appreciated, and their presence accordingly encouraged. These birds indeed are very tameable, and will afterwards live in harmony with other birds of various species. Montagu kept one together with a SparrowHawk and a Ringdove; at the end of six months he gave them all their liberty-the Owl alone returned-the others preferred their native freedom to the acquired habits of domestication. Another which escaped from the place of its captivity, returned in a few days voluntarily to it. The movements of this bird, when they can be closely observed, are very amusing; standing on one leg, it draws the other up into its thick plumage; and if approached, moves its head awry after the manner of a Chinese mandarin; or falls flat on its side, like Punch in the puppet-show. To be properly tamed they must be taker young; education, as is the case with the 'bipes implume,' is much less difficult then than afterwards. They will come to a whistle, or answer to their name, and settle on the shouldar of whornsoever they may be acquainted with. They take notice of music, and appear to be fond of it. 
One of these birds after having been tamed for some time, was found to be in the habit for some months, of taking part of its food to a wild one, which oreicame its skyriess so far as to come near the house, and it would then return to the kitchen and eat the remainder of its portion. Another of them is described by Meyer, as so tame 'that it rould cnter the door or window of the cottage, as soon as the family cat down to supper, and partake of the meal, either sitting upon the back of a chair, or renturing on the table; and it was sometimes seen for hours before the time, watehing anxiousiv for the entrance of the expected feast. This exhibition was seen regularly every night.' If captured when grown up, it sometimes refuses food, and its liberty in such, indeed in any case, should be given it. In cold weather a number of these birds have been found sitting close together for the purpose of keeping each other warm. The male and female consort together throughout the year. If aroused from their restingplace during the day, they fly about in a languid, desultory ranner, and are chased and teased by chaffinches, tomtits, and other small birds, by whom, indeed, they are sometimes molested in their retreat, as well as by the urchins of the village.

The flight of this bird, which is generally low, is pre-eminently soft, noiseless, and rolatile. It displays considerable agility on the wing, and may be seen in the tranquil summer erening turning backward and forward over a limited extent of beat. It also, its morements being no doubt directed by the presence or absence of food, makes more extended peregrinations. If its domicile be at some distance, it flies regularly at the proper time, which is that of twilight or moonlight, to the same haunt. During the day it conceals itself in hollow trees, rocks, buildings, and evergreens, or some such covert. It is a bird of cultivated taste, preferring eren villages and towns themselves, as well as their neighbourhoods, to the mountains or forests; and frequents buildings, church steeples, crevices and boles in walls, for shelter and a roosting-place; as also, ocsasionally, trees in unfrequented places. Montagu says that it sometimes flies by day, particularly in the winter, or when it has young. When at rest it stands in an upright position.

Moles, rats, and mice are extensively preyed on by the bird before us: as many as fifteen of the latter bave been found clcse to the nest of a single pair, the proaluce of the forage of one night, or rathei part of the prculuce, for 
others doubtless must have been devoured before morning. $\mathrm{He}$ who destroys an $\mathrm{Owl}$ is an encourager of vermin-nine mice have been found in the stomach of one, a veritable 'nine killer.' It is very interesting to watch it when hunting for such prey-stop short suddenly in its buoyant flight, and drop in the most adroit manner to the earth, from which it for the most part speedily re-ascends with its booty in its claw; occasionally, however, it remains on the spot for a considerabie time; 'and this,' says Sir William Jardine, 'is always done at the season of incubation for the support of the young.' It also oceasionally eats small birds-thrushes, larks, buntings, sparrows, and others, as also beetles and other insects. A tame one kept in a large garden, killed a lapwing, its companion.

Mr. Waterton argues that Owls cannot destroy pigeons, or the pigeons would be afraid of them as they are of Hawks; but this is not quite conclusive; for, as shewn in previous articles, pigeons and other small birds become habituated to the presence of Hawlis, and the latter, as it would seem, to theirs, so that both parties dwell together in amity as much as the Owls and pigeons, from acquired habit, or natural instinct.

'A person,' says Bishop Stanley, 'who kept pigeons, and often had a great number of young ones destroyed, laid it on a pair of $\mathrm{Ow}$ ls which visited the premises; and accordingly, one mconlight night, he stationed himself, gun in hand, close to the dove-house, for the purpose of shooting the Owls. He had not taken his station long, before he saw one of them flying out with a prize in its claws; he pulled the trigger, and down came the poor bird, but instead of finding the carcase of a young pigeon, he found an old rat, nearly dead.' These Owls feed on shrew mice, though rejected by cats and other animals, on account, as is supposed, of their disiliking either their taste or smell, but it would seem that they do not prefer them, for the Rev. Leonard Jenyns has observed that shrews are repeatedly found whole beneath the nest, as if cast out for the like reason; and I cannot help thinking that the very frequent occurrence of these mice dead on pathways in fields, which every one must have observed, may be attributable to the same cause. Fish is also occasionally the prey of this species of Owl, as well as of others, possibly at times of all. It has been suggested that the glare of their eyes may be a means of 
attracting the fish within their reach, but I must place this fancy in the same category with another which I have alluded to under the head of the Snowy Owl. Not to mention that other birds, such as the Osprey and Fishing-Eagle, which take fish in the same manner, by pouncing on them, find them ready to their claw without the need of any attractive influence, and that Owls see as well at the time they fly, as the Osprey at the time that it does, and that fish, as every fly-fisher knows, keep the same general positions by night that they do by day, it may be remarked, as those who have engaged in 'Barbel-blazing' in the River Wharfe well know, that though certain fish may sometimes be attracted more or less by light, as the salmon, yet they are not necessarily so, for that the light oftentimes seems to keep them pertinaceously at the bottom of the stream. Besides, how is the instantaneous catching of the fish by the Owl to be effected? They are caught from the middle of the pool.- Is the Owl to keep hovering over them after the manner of the Kestrel, until they have time to ascend from the depth and answer to the wooing of his eyes, inviting them in the language of Mrs. Bond to her ducks, ' $\mathrm{O}$ ! will you, will you, wont you, wont you, come and be killed?' 'You may call spirits from the vasty deep,' says Shakespeare, 'but will they come when you do call them?' and I am inclined to think that the fishes will be found in their deep, at least as deaf to such an invitation.

The White Owl is said to collect and hoard up food in its place of resort, as a provision agrainst a day of scarcity. It seizes its prey in its claw, and conveys it therein, for the most part, when it has young to feed; one, however, has been seen to transfer it from its claw to its bill while on the wing; but, as Bishop Stanley observes, 'it is evilent that as long as the mouse is retained by the claw, the old bird cannot avail itself of its feet in its ascent under the tiles, or approach to their holes; consequentiy, before it attempts this, it perches on the nearest part of tlie roof, and there removing the mouse from its claw to its bill, continues its flight to the nest. Some idea may be formed of the number of mice destroyed by a pair of Barn Owls, when it is known that in the short space of twenty minutes two old birds carried food to their young twelve times; thus destroying at least forty mice every hour during the time they continued hunting; and as young Owls remain long in the nest, many 
hundreds of mice must be destroyed in the course of rearing them.'

The note of this species is a screech-a harsh prolongation of the syllables 'tee-whit,' and it seldom, if ever, hoots. It has been asserted that it never hoots, but 'never's a bold word.' Sir William Jardine is not the man to misstate a fact. What if the White Owl should be to be added to the number of mocking birds? The Rev. Anđrew Matthews' reasoning on this subject is somewhat obscure: he is of opinion that the White $\mathrm{Orl}$ does not hoot, and in corroboration thereof, says that while a tame Brown Owl lived, the large trees round the house were nightly the resort of 'many wild birds of his species,' who left no doubs a'bout their note; but after his death, though the screeching continued, the hooting ceased.

If attacked these birds turn on their backs, and suap and hiss. The young while in the nest make an odd kind of snoring noise, which seems to be intended as a call to their parents for food.

The White Owl builds its nest, for the most part, in old and deserted, as well as in existing buildings and ruins, chimneys, eaves, or mouldering crevices, barns, dove-cotes, church-steeples, pigeon-lofts, and, but very rarely, in hollow trees. With the pigrons, if there are any in the place, they live in the most complete harmony, and unjustly often bear the blano of the depredations committed by jackdaws and other misciemeanants, both quadruped and biped.

The nest, if one be made at all, for oftentimes a, mere hollow serves the purpose, is built of a few sticks or twigs, lined with a little grass or straw, or, though but seldom, with hair or wool; and this is all that it fabricates, and that to but a small extent either of bulk or surface.

Tho eggs are white and of a round shape, geserally two or three, but sometimes as many as five or six in number, which may be accounted for by the ascertained fast that they will sometimos lay a first, second, and thirc cintch of two eg'ss cach. It will be seen that I have before alluded to sornething of the sort, and I have a most exiraordinary circumstance of the kind to narrate 'in loco,' of the Moorhen. The young have been found in the nest in the months of July and September, and even in December. A pair observed by the Rev. John Atkinson, of Layer MTarney Rectory, Kelvedon, Lissex, for four successive years, crdinarily reared four young. 
but had no more than one brood in the year. The remarks I have before made about the dispersion of birds are horne out by his observation, that 'the old birds remained, but the young ones seemed to leave the immediate neighbourhood; and again, in the list of the birds of Melbourne, Derbyshire, by J. J. Briggs, Esq., he says, writing of this same specis, 'hundreds of individuals have been reared in this spot, but it is never occupied by more than one pair at the same time: for no sooner is a brood fully fledged and able to maintair itself, than a pair of the strongest drive the rest of the family from the spot, and occupy it themselves.'

The appearance of this $\mathrm{Owl}$, owing to its somewhat wedgeshaped face, is very singular, especially when asleep, as it is then eren more elongated. The whole plumage is beautifully clean and pure. Old birds become more white. Male; weight, about eleven ounces; length, about one foot one inch, or a little more; bill, yellowish pink, yellow in the fully adult bird, and almost white in old age; cere, flesh-coloured; iris, deep brown, or bluish black: it is only opened a little laterally during the day, but quite round at night; there is a slight tinge of reddish brown round the inner corner of the eye. Head, pale buff, thinly spotted with black and white; the ends of the feathers are tinted with pale grey, and the tips marked zigzag with dark purple and black and white spots; crown, delicately barred with waves of pale grey; and is darker or lighter in different individuals; neck, pure silky white, sometimes tinged with delicate yellow or buff, and small brown spots; the ruff the same, but often marked on the upper part with yellowish or darkish tips; sometimes the upper part and the lower alternate these colours 'vicè versâ,', and sometimes it is yellowish all round; nape, as the head. Chin, throat, and breast, as the neck; back, as the head, but a shade darker: different specimens have more or less buff and grey.

The wings extend about half an inch beyond the tail, and expand to the width of three feet or over; greater and lesser wing coverts, beautifully spotted with white, like a string of pearls; primaries, buil on the outer webs, paler on the inner, edged with white, or altogether white, and barred or spotted with alternate black and white, both lreckled over: beneath they are yellowish white; towards the ends the dark bars shew faintly through; the second feather is the longest, the first nearly as long; secondaries, pale buff, barred 
or spotted irregularly in like manner with two white and two grey spots on each side of the shafts; tertiaries, as the back: all the quills are pure white on three fourths of the breadth of their inner webs; greater and lesser under wing coverts, white, sometimes pale buff with small dark spots. Tail, pale buff, with four or five blackish grey bars; the tip white; the side feathers almost entirely yellowish white, as are the inner webs of all the feathers except the two middle ones; it is jagged at the end, as are the wings; tail coverts, as the back; legs, feathered with. short white, or sometimes very light rufous hair-like feathers, shortest near the toes, which are flesh-coloured, but covered above with the feathers of the legs; claws, brown, thin, and much pointed; that of the middle toe slightly serrated on the inner side, and all grooved beneath. They become whitish in age.

The female resembles the male, but the colours are duller, and the breast is often marked with the yellowish grey of the back, and spotted on the tips of the feathers at its lower part with greyish black. Length, one foot three inches and a half. The wings expand to the width of three feet two inches or over.

The young birds are at first covered with snow-white down; the yellow plumage is gradually assumed, being at first paler in colour than in the old birds, and the breast less tinged with it; but being considerably like the old ones, there is not much change as they advance in age. It is long before they are able to fly. When fully fledged the length is about twelve inches; the bill pale flesh-colour; iris, black; there is an orange brown spot before it; the face is dull white, the ruff white, its tips rufous; breast, white; back, pale reddish yellow, mottled with grey and brown as in the adult; primaries, light yellowish, tinged with grey, and only a little mottled. Tail, as the primaries, and but faintly barred; claws, pale purple brown.

Varieties of this bird have occasionally occurred. Meyer mentions one which was pied yellow and white; another, of which the ground colour was perfectly white, and the pencillings on the upper plumage very indistinctly defined in the palest possible colouring. 



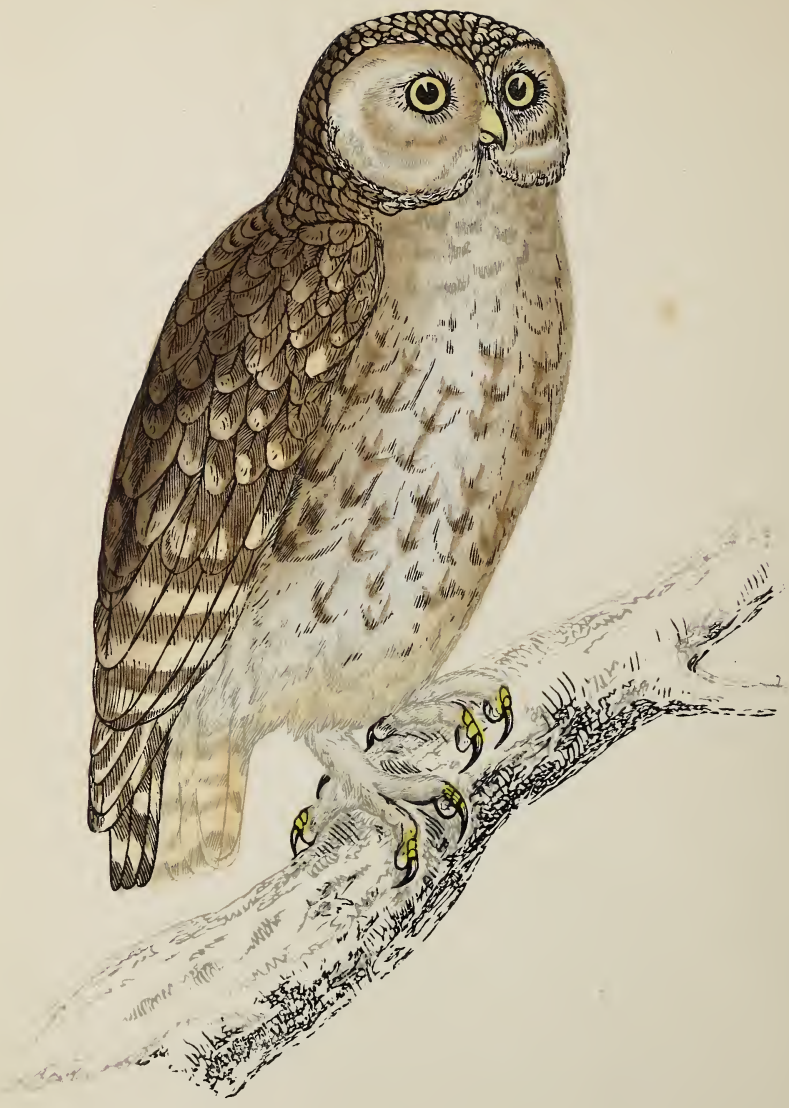






\section{LI'TTLE OWL,}

\section{LITTLE NIGHT OWI.}

\author{
Strix passerina, \\ " indipes, \\ ". dasypus, \\ Noctua passerina, \\ “ nudipes,
}

LixNeUS. IATHAM.

Nillison. Jaknise.

MEYER.

Jexyss. Selby.

Gould.

Strix-Some species of Owl. Passerina. PasserA Sparrow.

'THIs' says Wilson, 'is one of the least of the whole genus; but, like many other little folks, makes up in neatness of general form and appearance for deficiency of size, and is, perhaps, the most shapely of all our Owls.'

The Little Owl is common in Russia, Germany, Holland, Switzerland, Spain, Greece, and the Levant; and in the northern parts of North America, according to Wilson, but his description seems to me to be utterly inapplicable to the bird before us.

Two were taken in chimneys many years ago, in the parish of Lambeth. One was seen in Wiltshire, nailed up against a barn door, and probably many another has adorned the 'gamekeeper's museum.' Three are recorded to have been met with in Devonshire; one in Worcestershire; one in Flintshire; one near Bristol; a pair bred near Norwich, and two other specimens have been authenticated in Norfolk. One was shot at Widrington, in Northumberland, in January, 1812. One was on sale in July, 1842, in the Brighton market, and sud to have been shot in an orchard at Sheflield Park, near Fletching: it was believed from the light colour of its plumage to be a young bird. One was caught near Derby, which lived a long time in captivity, becoming so far tame as to know those who fed it: it used to drink much. 'Two others were met with in the parish of Melbourne, in the same county; 
and one in Herefordshire, in 1838, now in the collection of Mr. Chaffey.

In Ireland it has not hitherto been known to have occurred.

The Little Owl resorts to the vicinity of human dwellings, and finds a retreat in the crannies of old walls and roofs, churches and towers, as also in rocks, and the umbrageous recesses of pine and other forests, woods, and plantations. It is principally nocturnal in its habits, but takes wing occasionally in the daytime in dull weather, as well as in the twilight. It flies well, though its wings are not very long, but with an up-and-down motion, like that of a Woodpecker. If taken young there is no difficulty in rearing and taming it, and it is much used on the Continent as a decoy for entrapping small birds. 'That small birds,' says Bishop Stanley, 'generally speaking, have a great dislike to Owls, is clear, from the uproar that takes place if an unfortunate Owl is disturbed in the daytime, and compelled to appear in broad daylight, pursued, as it is sure to be, by a host of them, who persecute it by every means in their power. And we may therefore conclude, that they either take it for their real eıemy, the Hawk, or that it does now and then, when it can, feast upon any of them which may, by accident, fall into its clutches. Of this antipathy the bird-catchers in Italy know how to take advantage.' They are found alone or in pairs, not in companies, and are pursued themselves by hawks, rooks, magpies, and jays. During the breeding-season they fly about, and chatter even in the daytime.

It feeds on mice, as also on swallows and other small birds, which it sometimes catches on the roost, bats, and insects. According to Bewick, it is said to pluck the birds before it eats them.

The note resembles the syllables 'keu, keu, keewit, or koowit;' and when perched, 'pooh, pooh,' its voice being more drawn out in the breeding-season. It is the opinion of one author that the harsh and dissonant cry of the Owls is for the purpose of alarming their prey, and giving them opportunity to get out of the way to prevent their too great destruction. This is most surely a baseless theory, and runs counter to the whole course of nature. I think I may venture to assert that no peculiar faculty is given to any living creature for the immediate benefit of any other kind but its own-for that of any other individual but itself. Mr. Mudie, with rather more show of reason, suggests on the exact 
contrary, that the object is to alarm the prey sought, and so frighten them out of their coverts into the way of their pursuers, but this too is mere conjecture. One may almost wonder that it has occurred to no 'savan,' to suppose that the sole purport may have been to give different authors an opportunity of promulging each the separate notions of his own imagination on the subject.

Like the rest of the Owls this one breeds early in the spring.

The nest, so far as one is made, is built in chimneys, and other parts of buildings; pine and other trees, about, half-way up; as also in osier beds.

The eggs are from two to five in number, and white. The male takes his turn in sitting on them. They are said by Mr. Hewitson to vary in size and shape. The young are hatched in fourteen or fifteen days.

Male; weight, four ounces; length, eight inches and a half to nine and a half; bill, yellowish grey, edged and tipped with yellowish-very short, strong, much hooked, and surrounded at the base with bristly feathers; cere, dull yellow or greenish yellow; the feathers at its base are bristly at the tips, partially black on the shafts; iris, pale yellow-a streak of black extends from it to the bill; the eye is surrounded with yellowish white. Head, greyish brown, spotted with rufous white, with a central streak of the same on the crown; the ruff incomplete and inconspicuous, the feathers being a little more curved than the rest: the face is greyish white, passing into brown at the outer side of the eye; neck, brown, spotted behind and on the sides with large white spots, forming a collar, and with a large patch of the same in front; nape, brown, spotted with white; chin, white; underneath it a semicircle of yellowish brown, with darker bars; throat, banded with white, curving upward towards the ears; breast, yellowish or greyish white tinged with rufous, with brown streaks and spots, longer on the upper part and smaller lower down, forming bars on the middle of it; back, greyish brown, spotted with two white spots, edged with buff on most of the feathers.

The wings expand to the width of one foot eight or nine inches, and extend three quarters of an inch beyond the end of the tail. Greater and lesser wing coverts, greyish brown, the feathers with one white spot partly hid by the brown of the superincumbent feather, which together form lines of 
white, besides other smaller spots, the shafts being dusky. Primaries, brown, spotted with white or yellowish brown on the outer webs -in some specimens on each web; those on the inner, which are lighter, are larger, and together they form bars which partly shew through; the third is the longest, the fourth nearly as long, the second a very little longer than the fifth, the first shorter than the sixth, and the shortest in the wing. Secondaries, brown, barred with white, shaded at the edges of the bars into reddish brown; tertiaries, as the back; greater and lesser under wing coverts, white, with a few brown spots. Tail, brownish grey, with four, five, or six bars of rounded yellowish white or pale brown spots, and whitish at the tip: it is nearly even, and consists of twelve broad rounded feathers: beneath it is dull greyish brown, faintly barred with yellowish brown; tail coverts, as the back; under tail coverts, unspotted; legs, rather long, greyish yellow, feathered with short hairy yellowish white feathers, tinged with rufous, with a few dusky spots; toes, greyish yellow, slightly covered with bristly feathers on the upper surface; underneath they are rough; claws, yellowish brown, dusky or black at the tips, strong, and not much curved.

The female resembles the male, but is larger. Length, ten to eleven inches; the wings expand to the width of one foot ten inches or over.

In the young bird the head is rufous grey, clouded with white; the large round spots on the back, and the bars on the tail become gradually more marked than in the old birds, and the streaks on the breast appear. In age the birds become lighter-coloured. 


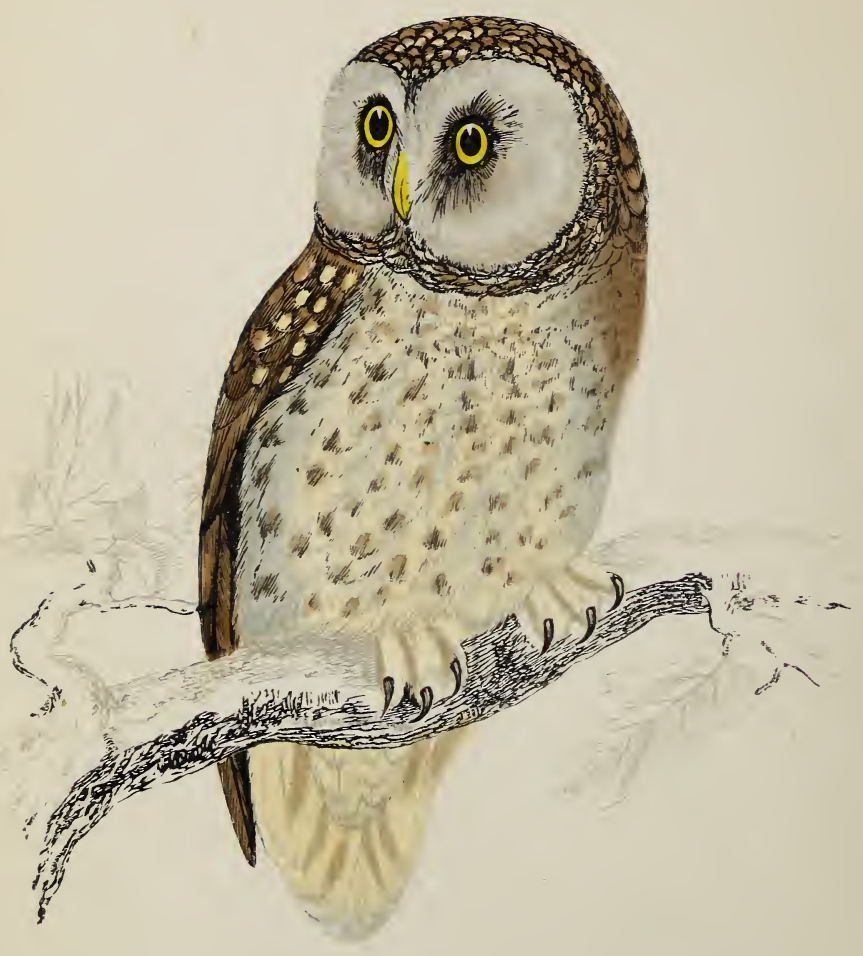

TENGMALM'S OWL. 




\title{
'TENGMALM'S OWL.
}

\author{
TENGMALM'S NIGHT OWL.
}

Strix Tengmalni,
" funerea,
Noctua Tengmalmi,

Strix-Some species of Owl.
Gmelin. Latham.

LiNNAUS.

JENYNS.

THIs pretty little Owl received its specific name from Gmelin, in compliment to the discoverer, Dr. Tengmalm, an able ornithologist, who lived near Stockholm, in Sweden.

It inhabits principally the northern parts of EuropeRussia, Sweden, Livonia, and Norway, and has also been met with in Germany, France, and Transalpine Italy. It is said to be very abundant in North America.

In Yorkshire, one was killed at Hunmanby, in the EastRiding, by Admiral Mitford's gamekeeper, about 1847. In 1836 a specimen, recently shot, was purchased in a poulterer's shop in London; another was killed the same year in Kent; one on the sea-coast, near Marsden, in the county of Durham, in October, 1848; and one near Morpeth, in Northumberland, in 1812 .

There has as yet been no discovery of the occurrence of this species in Ireland. In Scotland one was killed in May, 1847, at Spinningdale, in Sutherlandshire.

This bird is strictly nocturnal in its habits, and is so dazzled by the light of the sun, if by any accident forced into it, that it may easily be caught with the hand. It frequents wooded districts - the thick and extensive pine forests of the north, and orchards, and other lesser plantations. It may be easily tamed, even if taken in the adult state, and exhibits many amusing positions. It erects the feathers of the face at times to a considerable extent.

In flight this Owl is light and easy. 
Its food consists of mice, small birds, moths, beetles, and other insects. It does not swallow its prey whole.

The note sounds like the syllables 'keu, keu, kook, kook,' varied in the breeding-season into 'kuk, kuk,' repeated for several minutes at a time, at intervals of a minute or two. It is one of the superstitions of the Indians to whistle when they hear it, as sailors do in a calm when wishing for a breeze. The silence of the bird in reply, to use an Iricism, is considered an omen of death.

These Owls are said to breed in holes of trees, half way up them, and as being deficient in such an 'exhibition of industry,' to make no manner of nest, or only to use a little grass for the purpose.

The eggs are white, and two in number.

Male; length, from eight inches and a half to nine and a half; bill, pale greyish yellow or bluish white, darker on the sides, hid at the base by the feathers. Cere, sometimes dashed with black; iris, pale yellow; the eyes are surrounded by a dark ring, forming a band, which is broadest on the inner side. Head, reddish brown, spotted with small yellowish white spots; the ruff yellowish or greyish white, mottled or streaked with black over the eyes; crown, reddish brown; neck, spotted behind as the head. Nape, as the head, the spots larger, forming a sort of band; chin and throat, brown and greyish white. Breast, yellowish or greyish white, indistinctly streaked with lighter brown on the centre of each feather in the upper part, but only the tip on the lower; back, as the head, but the spots larger.

The wings expand to the width of one foot eleven inches; greater and lesser wing coverts, as the back, partially spotted with white. Primaries, reddish brown, barred on the outer. webs with three or four oval white spots; the third and fourth are the longest in the wing, the latter the longer of the two; Meyer says the former. They reach to within an inch of the end of the tail. Tertiaries, the same, the spots more square; greater and lesser under wing coverts, white, clouded with brown. Tail, reddish brown, slightly rounded, and barred with four or five series of narrow white spots; it extends about an inch beyond the wings: it is greyish white beneath, the bars shewing through; under tail coverts, white. Legs, short, and, as the toes, yellow, feathered with very soft greyish or whitish yellow hairy feathers, slightly spotted with brown. Claws, slender, yellowish brown, and dusky at the tips. 
The female measures from nine inches and a half to eleven and a half; the face dull white, the black spot over the eye smaller and paler than in the male. Breast, more spotted than in the male, and the brown of the back darker.

Young; length, eight to nine inches; bill, yellowish grey; iris, yellow. The bristly feathers of the face dusky black, with white bases; the ruff brown, but indistinct, a little spotted with white around the eyes. Breast, whitish, mingled with brown; back, reddish brown; primaries, barred with four rows of small round spots. Tail, barred as the wings; under tail corurts, dull white, tipped with brown. 


\title{
MOTTLED OWL.
}

\author{
AMERICAN MOTTLED OWL. RED OWL, (YOUNG.) \\ LITTLE COMMON SCREECH OWL.
}

Strix Asio,

Strix-An Owl.
LinNaUs.

Asio-............?

THIs Owl is a native of North America, and is met with in Oregon and Columbia, as well as, abundantly, in New Brunswick, Nova Scotia, Newfoundland, and Labrador.

A single specimen has occurred in this country. It was shot in Hawksworth Wood, the property of Lord Cardigan, on the banks of the River Aire, near Kirkstall, Yorkshire, in the spring of the year 1852. There was another with it at the time, and no doubt, from the season of the year, they had been building, or would have built; but every rare bird is so hunted, as the saying is, 'from pillar to post,' that there is small chance of any increase of family.

Richard Hobson, Esq., M.D., of Leeds, an excellent and most acute naturalist, recorded the fact, with full particulars, in my magazine, 'The Naturalist,' August, 1855.

These Owls rest or spend the day either in the hole of some decayed tree, or in the thickest parts of evergreens. They are generally found perched on the roofs of houses, on fences, or garden gates.

They have been kept without difficulty in confinement, and seem comfortable and happy uttering their notes with as much apparent satisfaction as if at liberty.

Audubon writes as follows of the bird:- 'The flight of the Mottled Owl is smooth, rapid, protracted, and noiseless. On alighting, which it does plumply, it immediately bends its body, turns its head to look behind it, performs a curious 




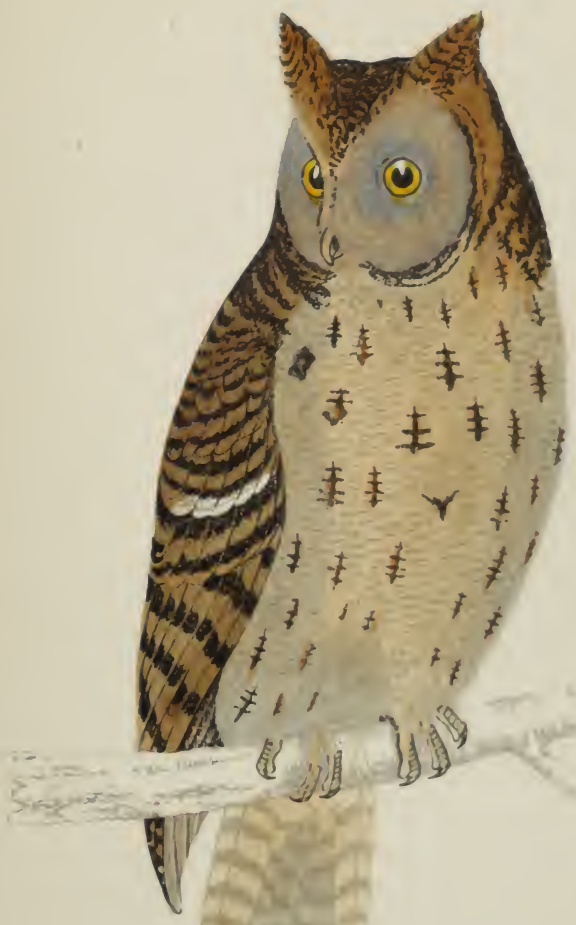



nod, utters its notes, then shakes and plumes itself, and resumes its flight in search of prey. It now and then, while on the wing, produces a clicking sound with its mandibles, but more frequently when perched near its mate or young. This, I have thought, is done by the bird to manifest its courage, and let the hearer know that it is not to be meddled with, although few birds of prey are more gentle when seized.'

They hunt through the woods, or over fields, in search of small birds, field-mice, and moles, from which they chiefly derive their sustenance.

The note, which is heard at the distance of several hundred yards, is a tremulous, doleful, mournful chatter, and, like that of other Owls, is thought of an ominous import, and with as little reason as in their case.

The nest is placed in the hollow trunk of a tree, sometimes only some six or seven feet from the ground, but at other times as high as from thirty to forty. It is composed of a few grasses and feathers.

The eggs are four or five in number, of a round shape, and pure white; only one set of eggs is laid, unless the nest is disturbed. The young remain in the nest until they are able to fly.

The ear-tufts on the head are composed of a series of ten feathers, commencing over the middle of the eye, and extending backwards a quarter of an inch beyond it.

The young are fully fledged by the middle of August. The grey plumage is not assumed till the bird is two years old. In the interval the feathers are sometimes a mixture of both colours - sometimes of a deep chocolate colour, and again nearly black.

Length, from about ten to ten inches and a half; the upper mandible, which is much curved, is black on its basal half, the lower one black, the tip horn-colour. Cere, bright yellow; from twenty-five to thirty black bristles, filamented on their basal half, but single on the remainder, surround the bill. On the crown the feathers are divided along the centre of each with a chocolate-coloured stripe, and edged with light brown. The disc is formed by an extension right and len of stiff feathers, standing out from the tufts covering the ears, which tufts constitute the horns, the feathers of which are an inch and a quarter in length. Neck on the back, and nape, marked in the same manner but the stripe narrower, 
the sides of the neck lighter coloured, but with similar markings. The chin has the feathers half white on the lower portion, the upper covered with light brown pointed spots; the throat similarly marked but gradually darker; the feathers of the breast have broad chocolate-coloured longitudinal patches, crossed with narrow stripes of the same colour. The back on its upper part has chocolate-coloured central stripes on the feathers, with alternate transverse light brown and dark brown bars; on the lower part it is similarly marked but without the longitudinal and central chocolate-coloured stripes.

The wings have the second quill longer than the first, the third than the second, and the fourth than the third. The greater wing coverts have longitudinal and central chocolatecoloured stripes, the lower portions of the outer webs being white, the inner webs light brown; lesser wing coverts marked in the same way, shewing a longitudinal white stripe when the feathers are naturally arranged. Of the primaries, the first has five white bars on the outer web, and three on the inner. It is beautifully pectinated on its outer web for the space of half an inch from the tip; the inner web abruptly notched for an inch and a half. There are on the outer web seven yellowish white patches turned from the margin towards the shaft, and four rather light-coloured yellow bars on the inner web, running obliquely, the last bar being somewhat indistinct; the second feather is pectinated on the outer web for the length of a little over an inch, commencing at about the same distance from the tip, and on this web there are eight rather light yellow patches; on the inner web is an abrupt notch nearly an inch and a half from the tip, and three distinct and three indistinct bars. The third feather begins to be slightly pectinated at not quite an inch and a half from the tip, and extends for only half an inch upwards on its outer web, on which are seven rather light yellow bars; on the inner web, and on its upper portion, are three similarly-coloured bars, and on the lower part four indistinct ones. The fourth feather in place of being pectinated is slightly hollowed; on it are eight rather light yellow bars, and on the inner web are four distinct and four indistinct bars. The five first quill feathers have a delicately-formed fringe on the margin of their inner web, opposite the pectinated portion of the outer web. Greater under wing coverts, white on the upper portion, ash-coloured on the lower; lesser under wing coverts, yellowish, with ash-coloured 
bars. The tail, which consists of twelve feathers, has the two central ones slightly the longest, and the outer one on each side the shortest; on each are eight pale yellow transverse bars, the ends of all these feathers round. The upper tail coverts on their lower portions have a chocolate-coloured central stripe, while the upper portions are a mottled brown. The legs are covered with hairy feathers, having a pale yellow ground with a mottled brown surface; toes partly scutellated, the remainder covered with hairy feathers; claws, very much curved, and of a dark horn-colour. The three lobes under each toe are prominently deep, and of a sharp wedge shape. The above description is compiled from particulars which Dr. Hobson has been so obliging as to favour me with. 


\section{HAWK OWL.}

CANADA OWL.

Strix funerea,
Sturnia funerea,
Noctua funerea,

Strix-Some species of 0 wl.
Temmincr.

Gould.

JENYNS.

Funerea-Funereal.

THE soft plumage of Owls, and the formation of the feathers of their wings is, in the opinion of some writers, to enable them to steal noiselessly on their prey. This, however, I think is at best but a fanciful speculation; as far, at least, I mean, as regards any peculiar advantage being afforded to the Owl, 'par excellence,' on this account. No birds of prey make such a noise with their wings as by it to give their prey timely notice of their approach-the Owl, therefore, is not especially privileged in this respect. Q.E.D.

The Hawk Owl is a connecting link between the Owls and the Hawks, possessing many points of similarity to each; the long tail and small head of the latter, as well as the habit of flying by day; and resembling the former in the ruff and the feet; one might almost think it a hybrid between the two.

This bird is an inhabitant of Germany, France, Denmark, Norway, Sweden, Lapland, Russia, and other parts of the north of Europe: in some years it appears far more abundantly than in others. It is plentiful in all the high latitudes of North America. A single specimen of this Owl was long 'left alone in its glory' as a British species. One was taken at sea in an exhausted state off the Cornish coast, in March, 1830. It lived afterwards for a few weeks in the care of Dr. Birkett, of Waterford, to whom it was given, the ressel having been bound to that port. A second, however, has been now recorded by E. T. Higgins, Esq., in the 'Zoologist,' 


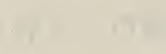

(2) 


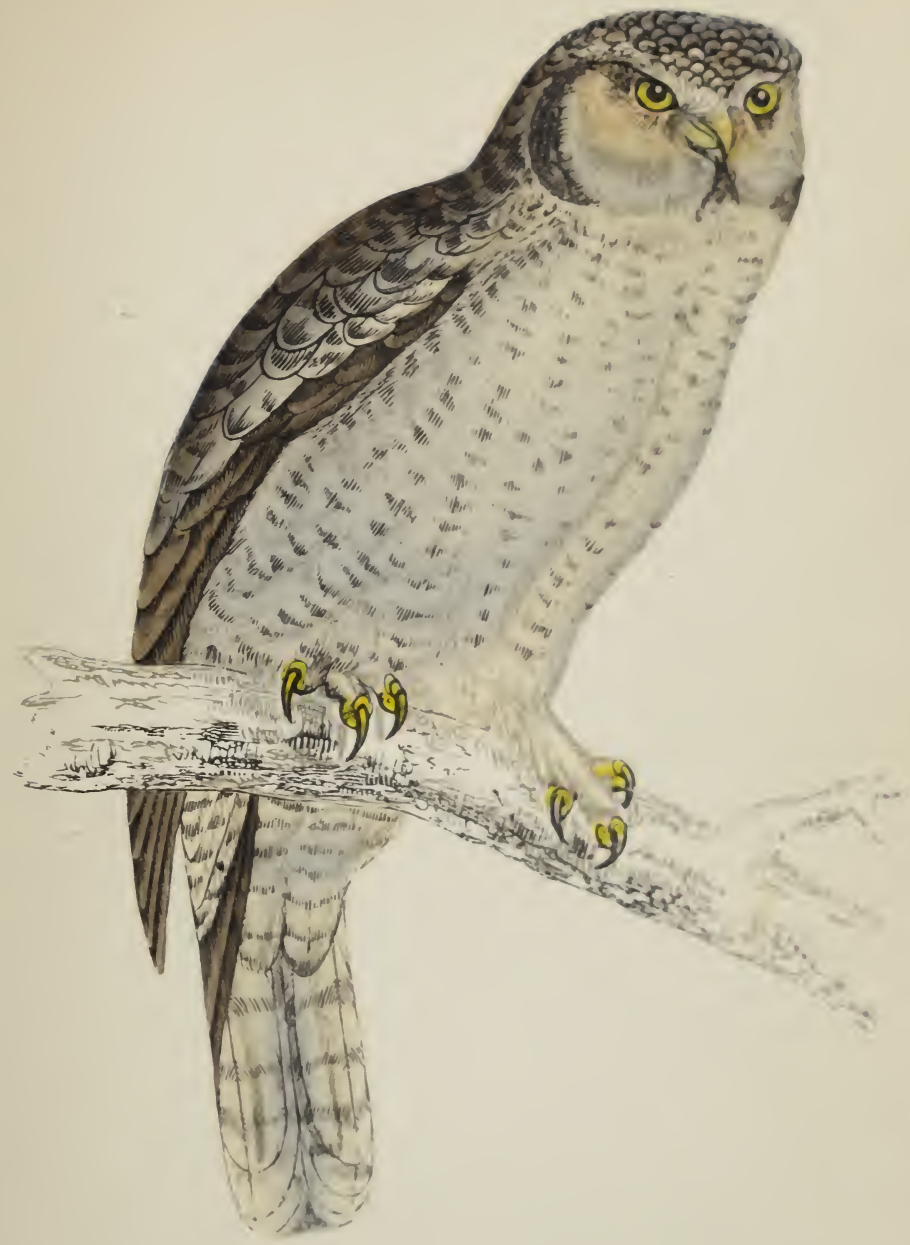



as having been shot whilst hawking for prey on Backwell Hill, near the Yatton (Clevedon) Station, of the Bristol and Exeter Railway, at about two o'clock, on the 25th. or 26th. of August, in the year 1847, the sun shining bright at the time.

This species flies by day, but seeks its food mostly in the morning and evening. It frequents small woods, and is a bold and daring bird, frequently carrying off game from the fowler, whom it attends for the purpose: it is easily tamed. Wilson remarks in writing of this $\mathrm{Owl}$ that it wants the filaments on the outsides of the quill feathers which the Owls that fly by night possess, to enable them, as he imagines, to steal more noiselessly on their prey; but surely such an advantage would be far more useful by day than by night. There is indeed an all-wise reason for everything in nature; but I believe we are in the dark as to by far the most. We are apt to argue that such or such is the reason of this or that fact, or the use of this or that possession, when the presence or the absence of the like in some kindred or dissimilar species at once overturns our shallow hypothesis.

The flight of the Hawk Owl is rather slow: at times it mounts to a considerable height, and is also said to move in circuitous rounds from tree to tree, and to roost sometimes on the ground in marshy situations, as do the Harriers.

Its food consists of rats and mice, partridges and other birds, and insects. In winter it makes great havoc among the flocks of ptarmigans.

The note of this bird is said to resemble that of the Kestrel.

The superstitions of all nations in all ages have associated the doleful note of the Owl with the idea of calamity and death, yet all the while it is for the most part nothing but a love-note that is uttered, or a voice of alarm; as when, as described in Gray's most truly beautiful poem, the 'Elegy written in a country churchyard'-

'The moping Owl does to the moon complain
Of such as wandering near her sacred bower,
Molest her ancient solitary reign.'

The nest is built in a tree, and is composed of sticks, gras., and feathers.

The eggs are white, and like those of the Owls generally, of the dual number. 
Male; weight, about twelve ounces; length, about one font three inches; bill, orange yellow, and almost hid by the feathers: Mr. Higgins describes his specimen as having the upper part white, and the lower horn-colour. Iris, bright orange according to some accounts, but yellow according to others; bristles intermixed with yellowish white feathers cover the parts about the bill. Head, small, dusky, and white on the sides, the feathers being spotted and the face narrow, a black-edged band passes down to the wing; the ruff indistinct, a black crescent only appearing about the ears; crown, dusky black, thickly dotted with white, each feather having three white spots. Neck, olive brown, marked on the sides with a curved streak of brownish black, with another behind it of a triangular form; nape, olive or blackish brown, a good deal marked with white; chin, dusky, with a large spot of brownish olive; throat, dusky in front, white on the sides, the shafts of the feathers being black. Breast, white above, with a blot of dark brown on each side, united by an irregularlyformed band; below elegantly barred with dark brown lines. Back, brownish olive, speckled with broad spots of white.

The wings-greater and lesser wing coverts, as the back, but less spotted; primaries, dark brown, barred with four or five yellowish white spots on the outer web near the tip. Secondaries, the same, with two or three spots forming irregular lines, and some of them have white spots on the inner webs also; tertiaries, brown, spotted on the outer webs, forming, when the wing is closed, a broad and long band of white with a few irregular bars of brown; the first feather is the shortest, the third the longest, the fourth a little shorter, the second a little less than the fourth. Greater and lesser under wing coverts, white with brown bars, some of them regular, but others alternately, on the outer and inner webs. The tail extends about three inches beyond the end of the wings. It consists of twelve feathers, and is wedge-shaped, rounded at the end, and of a brownish olive colour, with six or seven or more narrow bars of white, the three upper ones concealed by the tail coverts; they are much more distinct on the inner than on the outer websin the latter assuming more the character of spots than of bars, and the tips white, the bars shew clearly through, bending in the middle towards the end; tail coverts, as the back, and with a broad terminal white spot; under tail coverts, with broad white bands, and rarrow brown ones. 
I Legs and toes, completely covered with yellowish white plumage, barred with narrow lines of olive brown; claws, horn-colour, long, and finely arched: that on the middle toe is sharp-edged on the inner side.

Female; length, from sixteen to seventeen inches and a half. The breast is blotted on the upper part; on the back her plumage is darker-coloured than that of the male. The wings expand to two feet seven or eight inches-they reach to half the length of the tail; primaries, nearly black.

The young are less clearly coloured than the old birds. 


\title{
GREAT SHRIKE.
}

\author{
GREY SHRIKE. GREAT GREY SHRIKE. \\ ASH-COLOURED SHRIKE. GREATER BUTCHER BIRD. \\ MURDERIYG PIE. SHRIKE. SHREEK.
}

CIGYDD MAWR, OF THE ANCIENT BRITISH.

Lanius excubitor, Innseus. Pennaxt. Montagu. Bewick.

Lanius-A butcher. Excubitor-A sentinel.

THE uncertainty even of Swainson himself as to the distinctness of the supposed species he has described under the name of 'Lanius excubitorides,' and the still farther uncertainty as to whether that variety or species, if it either the one or the other, has been met with in England, obliges me to omit it from the 'British Birds.'

The species before us is found in Denmark, Russia, Norway, Sweden, Lapland, Germany, France, Spain, Italy, Holland, and other countries of Europe, as also in all the temperate parts of North America. In England specimens have been procured in Yorkshire, (one on the 18th. of April, 1849;) Cumberland, Northumberland, Durham, Norfolk, Suffolk, Cambridgeshire, Worcestershire, Dorsetshire Deronshire, Wiltshire, Sussex, Surrey, Cheshire, Essex, Staffordshire, Derbyshire, Bedfordshire, Warwickshire, and Kent.

In Ireland, in the counties of Down, Antrim, Sligo, Londonderry, Westmeath, Dublin, Tipperary, Waterford, Cork, and the Queen's County. A few have been met with in Scotland.

In the Orkney and Shetland Islands it has hitherto been 'non inventus.'

This species is sufficiently scarce in this country to make it a valuable addition to a collection; and at the same time not so extremely rare as to render its acquisition almost hopeless. 



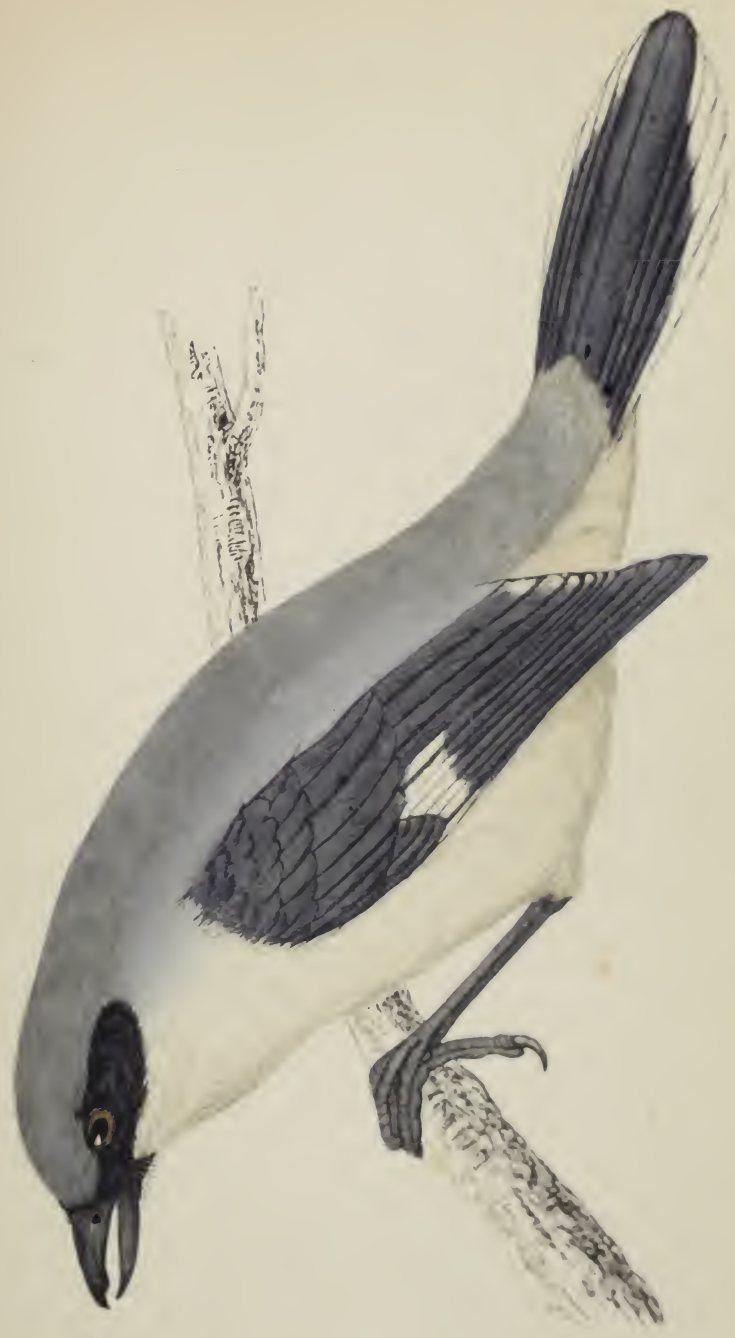



It frequents groves and forests, wooded hedge-rows and parks. During migration it may be seen perched upon some hillock, or hovering in the air, and descending in pursuit of its prey when discovered within reach.

These birds may be readily tamed, even if captured when adult, and will come to a call. When in confinement they follow out their natural bent, adapted to the circumstances they are in, affixing their prey between the wires of the cage, doing so from evident choice, that they may pull it from between them, and leaving it there when they do not require it for immediate consumption. 'This bird,' says Yarrell, 'is used by falconers abroad during autumn and winter when trapping Falcons. The Shrike is fastened to the ground, and, by screaming loudly, gives notice to the falconer, who is concealed, of the approach of a Hawk. It was on this account, therefore called 'excubitor'-the sentinel.' Mr. Knapp, however, the author of the excellent 'Journal of a Naturalist,' says that the name was appropriately given to it by Linnæus, from its seldom concealing itself in a bush, but sitting perched on some upper spray, in an open situation, heedful of danger, or watching for its prey. Rennie relates that in liussia it is trained to catch small birds, and is valuable for its destruction of rats and mice. It is a very courageous bird, attacking fearlessly those that are much its superiors in size, even the Eagle, it is said, and will not allow a Hawk, Crow, or Magpie to approach its nest with impunity. One has been taken in the act of pouncing on the decoy bird of a fowler, 'who,' says Bishop Stanley, 'having kept it awhile in confinement, was soon glad to get rid of it, as the sound of its wice at once hushed to silence the notes of his choir of birds. 'T'beir antipathy when at large, is shewn at times by teasiog it in concert, as they do an Owl, though at other times they surround him without any apparent fei:.' Montagu, who kegit several, found that at the end of two months they lose the affection for each other which they seem to exhibit in the wild state, and quarrel and fight even till one is slain. Civilization it would appear, anong birls tan mong ment, lass its concomitant evils as well as adrantiges. I was aluost in despair for many days,' says some traveller in an wioliahited regrion, 'but at length to my great joy I espied a gibbet - then

I knew at once that I was coming to a civilized pountry: The flight of this species is interrupted and irregelar. When perched, the tail is in constint motion. 
Its food consists of shrew and other mice, smali birds, and occasionally even partridges, fieldfares, and other larger ones; lizards, frogs, as also the larger insects and grasshoppers; and they are said to resort to the same thorn on which to fasten their captures. In carrying a mouse or a bird some distance they have been seen to shift it alternately from the bill to the mouth, as an alleviation of the weight.

In the spring they are noisy. It is said that they imitate the notes of small birds for the purpose of luring them to their destruction, but I cannot myself entertain this supposition. One of their notes resembles that of the Kestrel, and it changes 'ad libitum' from the 'forte' to the 'piano.' Meyer says, 'the call of this bird sounds like the words 'shack, shack,' and 'truewee' is one of its spring notes: it is also said to sing very pleasingly a sort of warbling song.' Mr. Knapp says that these birds breed annually near his residence, in the neighbourhood of Thornbury, I believe, in Gloucestershire; and the Rev. N. Constantine Strickland, at the foot of the Prestbury hills, near Cheltenham. Lewin too has said that he had seen them in Wiltshire, and had no doubt of their breeding there.

While the hen is sitting, the male is very vociferous if any one approaches the nest, and when the young are hatched both exhibit a clamorous anxiety which often defeats their object, and betrays their callow brood to the callous birdnester. The young indeed themselves join in the untoward imprudence.

The nest is built in trees, hedges, or bushes, some height above the ground. It is large and ill-concealed, but well put together; and is composed of grass, hay, small roots, stalks, and moss; and lined with wool or down, or finer parts of the outside materials.

The eggs are four or five, and sometimes it is said, as many as six or seven in number. They are of a greyish, bluish, or yellowish white ground colour, spotted at the thicker end with different shades of grey and light brown, forming an irregular band-the character of the eggs of all the Shrikes.

Male; weight, a little above two ounces; length, from nine to ten inches; the upper bill is bluish black at the base, and there is a strong projection near its point, which is much hooked; the lower one yellowish brown at the base, brownish black at the tip; a black streak runs from it to the eye, and a narrower one under the eye: over the former is a streak 
of white, which runs into the grey of the nape, widening into an oval patch over the ear; iris, dark brown; bristles cover the nostrils; forehead, dull white; head, crown, neck, and nape, light ash grey; chin, throat, and breast, white; back, light ash grey.

The wings, short-they expand to the width of one foot two or three inches; greater and lesser wing corerts, as the back; primaries, black-white at the base, shewing, when the wing is closed, either one or two white spots, according as the upper one is or is not hid by the superincumbent feathers; the first is only half as long as the second, which is nearly as long as the sixth; the third, fourth, and fifth, nearly equal, and longer than the second; the two former the longest in the wing: underneath they are slate-coloured. Secondarics, black, white at the base, and also tipped with white; tertiaries, black tipped with white; this white wears off towards the end of summer; greater and lesser under wing coverts, white. The tail wedge-shaped, of twelve feathers, has the four central ones purple black, the next side feather obliquely tipped with white, the next one fourth, the next one third, and the outer one almost wholly white; underneath, the markings are the same, but less clear; tail coverts, as the back, but paler; legs, toes, and claws, black.

The female resembles the male, but the colours are more dull, the blue grey assuming a brownish tint; and the breast is marked with numerous semicircular greyish lines. The young males resemble the females.

Temminck mentions a variety nearly pure white, the black parts slightly tinged with grey; another is described entirely white with a tinge of rich yellow. Very old birds shew indications of bars on the tail. 


\section{RED-BACKED SHRIKE.}

CHEETER. FLUSHER. LESSER BUTCHER BIRD. MIURDERING PIE. JACK BAKER. WHISKEY JOHN.

Lanius collurio,

Pennant. Montagu. Bewick.

Lanius-A butcher.

Collurio-............?

THE species before us is a native of the three quarters of the globe which comprise the old world, being found in Europe-in France, Spain, Germany, and Italy, and even northward-in Russia, Sweden, Norway, and Denmark. It is met with in Egypt, the rest of the north of Africa, and so far south as the Cape of Good Hope, as well as in the intermediate parts; in Asia Minor also; and Meyer says that it is a native of North America.

This bird is far from uncommon in the south of England, and occurs, though sparingly, towards the north. In Yorkshire it has been frequently seen in the West-Riding, being met with, as I am informed by Mr. Allis, senior, occasionally near Huddersfield and York, not very uncommonly near Sheffield and Doncaster, (though I have never seen it near the latter place,) and he says that it breeds occasionally near Halifax, but is becoming scarce. In Dorsctshire $T$ have scen it as a common species; I have also seen it in Kent.

It is found in Wiltshire, Sussex, Essex, Gloucestershire, Suffolk, Derbyshire, Norfolk, Middlesex, and other southern counties; occasionally in Northumberland, Cumberland, and Durham, and also in Wales; but has not as yet been observed in Ireland and Scotland, which is rather singular, as the latitude of its European range is higher.

It frequents hedge-rows principally, but also the sides of coppices and woods, and such a place as an old deserted quarry or lime-pit. It is seldom found among trees of large 

growth, and is generally seen in pairs. Mr. Mudie's account of the locality of this species is one of the most extraordinary of the many extraordinary ones he has promulgated. He says that though it is a short-winged bird, and therefore 'gets through the air with more labour' than many of the birds which are found in the south-eastern part of the island; it 'leaves the gravelly and clayey districts, and takes up its abode in a central zone, beginning at the channel and terminating at the light soils.' He has himself correctly described this as 'the most remarkable part of its natural history;'"the climate of that zone is warm, and the soil peculiarly adapted to the habits of the larger beetles, which seem the natural and peculiar food of these birds.' He very properly adds that the 'habits of the Red-backed Shrike deserve to be studied.' Its name of 'Flusher,' he considers to be a corruption of 'Flasher,' from its looking like a 'flash of fire' in darting through the air; but I think it much more probable that it is derived from 'Flesher,' another word for a butcher, the name of the bird itself.

The Red-backed Shrike arrives in this country at the end of April or the beginning of May, and quits it again in September or October.

This species also seems to be distinguished for affection towards its partner and its young. The following anecdote, illustrative of this its disposition, is recorded by Meyer:- 'A male Red-backed Shrike was caught in a garden by a cat; the gardener, who saw the circumstance, succeeded in rescuing it from the animal the very moment it happened, in time to save its life. It was put into a cage and placed in a sitting-room, in the house close by. There were several persons in the room at the time; but notwithstanding their moving about, the female, its companion, came in at the window, settled on the cage, and was secured by one of the party, without attempting to fly away; they were subsequently both placed in the same cage.' He further adds - 'the female will hardly fly from the nest when she has eggs; and if disturbed after the young are hatched, both parents remain either in the bush that contains the nest, or on a neighbouring tree, until the danger is past; and, to draw off attention from the spot, they keep moving in opposite directions, uttering all the while their alarm-cry. We have seen them help the young ones out of the nest for the purpose of hiding them in the thicket beneath; and the moment they have reached the 
ground, not another chirp is heard from the nestlings, which have apparently received a signal to be quiet, although the parent birds, perched in a tree at a little distance, keep up a continual clamour.'

It has a habit of moving its tail rapidly from side to side, and twirling it round, when excited by the appearance of danger. It is easily tamed.

The food of the Red-backed Shrike consists of mice, small birds, such as finches and others-one has been seen pursuing a blackbird-frogs and lizards, but principally of grasshoppers, beetles, dragon-flies, cockchaffers, and other insects. Occasionally they are taken in the nets of fowlers, in the act of striking at their decoy birds. They may usually be seen perched on some small isolated spray of a hedge or bush, from whence they dart after their prey, very much after the manner of the Flycatchers. In flying from one place to another, they first drop downwards, and after arriving at their destination, rise upwards again to the spot where they wish to perch.

Most extraordinary is the manner of feeding of the Butcherbirds-whence their name. Occasionally, indeed, perhaps it may be that they are then unusually hungry, they hold the bird or insect they have killed between their claws, or fix it between two stones, or in some narrow place, and pull it to pieces after the manner of the Hawks, breaking the skull, and eating the head first as the most choice morsel. In general, however, after killing their prey, they fix it in its proper attitude on a thorn, or in the cleft of the small branches of a tree, and making these serve as the tenter hooks of a larder, garnish the hedge with their game, and consume it 'secundum artem.' Nay, it has been imagined that they also use such as baits to entice small birds within range; for otherwise the latter are shy of their company, and shew their dislike, if one approaches, by sounds of anger or distress. They are said to have been known to pull young pheasants through the bars of a coop, and are strongly suspected of making free with the nestlings of other birds, when the parents are from home.

In confinement their habit is the same with regard to their prey, as that of the preceding species.

The indigestible part of the food is disgorged from tho mouth of the Shrikes in small pellets, after the manner of the Hawks and Owls.

The Red-backed Shrike makes some pretensions to be a song 
bird, but its vocal powers, though described as pleasing, are not of first-rate order. The note resembles that of the Sparrow, which is not pre-eminent for beauty; but it occasionally warbles a little, and is said to imitate the voices of other birds. The clamorous habit spoken of under the Grey Shrike, is not peculiar to it, but attaches also to the one before us: it seems to run in the family. They are particularly attentive to their young, feeding them after they have left the nest.

The nest is placed, without much attempt at concealment, in a hedge or bush. It is large for the size of the bird, being from six to seven inches across, somewhat deep like a cup, and is composed of the stalks of plants, grass, wool, and moss; and is lined with small roots, and, occasionally, it is said, with hair. The edge of the top rather projects over the side.

G. Grantham, Esq. has favoured me with the egg of this bird, which I have often in former years taken myself, more or less spotted with red. In general they are pale reddish white, spotted with two shades of darker red and reddish brown, and the base is encircled by a belt, formed of an irregular conglomeration of the same. Occasionally they are pale bluish white, or white, and sometimes greenish white, spotted with brown and grey, or rufous. They are five or six in number. The band already alluded to has been occasionally found at the narrow end.

The old and young birds keep up the family connection until the time for migration has arrived. The latter do not moult until after they have left this countyy, but return in the garb of their perfect birdhood.

Male; weight, eight drachms; length, about seven inches or seven and a half; bill, bright black, strong, thick, much hooked, curved, and notched near the point-a black band runs from over the bill, above and below the eye to the nape. Iris, reddish brown; forehead, black; head, bluish grey, sometimes tinged with yellowish; neck, white on the sides; nape, bluish grey, sometimes tinged with yellowish; chin, nearly white; throat, white; breast, pale yellowish pink; back, rufous on the upper part, but lower down bluish grey. The wings expand to about twelve inches and a quarter; greater and lesser wing coverts, rufous; primaries, dusky black, edged with rufous on the outer web; the first feather is not half as long as the second, the second and fourth nearly equal, the third the longest in the wing. Secondaries, the same, with the margins 
broader; tertiaries, bordered with rufous as the secondaries. The tail, which extends about an inch and a half beyond the wings, and consists of twelve feathers, has the two middle ones black; all the rest white at the base, and black towards the end, 'fine by degrees and beautifully less,' until the outside feather on each side, which is about a quarter of an inch shorter than the others, making it slightly wedge-shaped, retains only a single dark spot-all are tipped with white; the shafts are black; upper tail coverts, bluish grey, with a dash of red; beneath it is the same, but less distinct; under tail coverts, white. Legs, black, long, and slender; toes and claws, black.

The female in very old age assumes, at all events occasionally, the plumage of the male, but in general she differs much; her weight, about ten drachms; bill, dark brown-the base of the lower part yellowish white. Iris, dark brown; over the eye is a light streak-no dark one-a brown streak below it; head, ferruginous brown. Neck and nape, ferruginous brown, tinged with grey below; chin, dull white; throat, greyish white; breast, greyish white, the feathers margined with a semicircular dusky line; back, ferruginous brown above, lower down with a tinge of grey. Primaries, secondaries, and tertiaries, as in the male, but the rufous margins narrower; tail, ferruginous, the outer web of each outside feather and the tips, dull white; underneath it is grey, tipped with white; under tail coverts, dull white. Legs and toes, blackish brown.

The young nearly resemble the female. Over the eye there is a yellowish white streak; breast above, yellowish white, below, the same, barred with brown on each feather. The feathers on the lower part of the back have a narrow dark border, the rest of the back is yellowish brown, tinged with grey, and the feathers barred at the tip with brown, edged with a lighter shade. Tail, yellowish brown, darker at the tip, the two outer feathers edged with white.

A variety of this bird has been met with near Lewes, of a uniform pale fawn-colcur. 


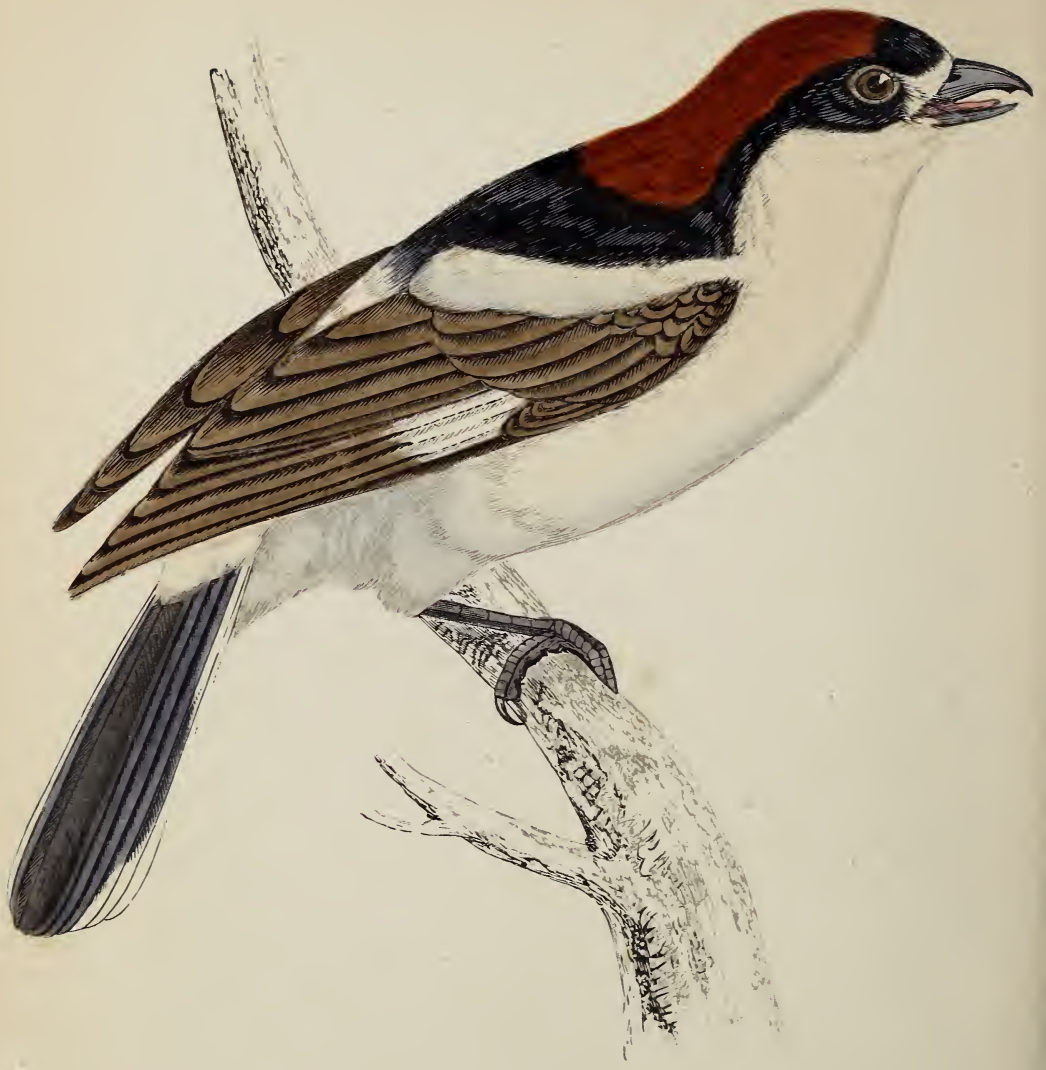






\section{WOODCHAT.}

WOOD SHRIKE. WOODCHAT SHRIKE.

$\begin{array}{cl}\text { Lanius } & \text { rufus, } \\ \text { " } & \text { rutilus, } \\ \text { pomeranus, }\end{array}$

Lanius-A butcher.
Brisson. Bewrok.

Latham. Mostagu. Gaelix.

This Shrike is found in Europe-in Germany, France, the Netherlands, Switzerland, Sicily, Italy, and Greece. In Africa -in Egypt, Senegal, and at the Cape of Good Hope.

The following are the only specimens of the Woodehat that appear to have been recorded as having occurred in England: -In Yorkshire, one; in Kent, two, one of them near Canterbury; in Norfolk, two, one of them near Swaffham; in Suffolk, two; in Worcestershire, one, near Evesham; two in the Scilly Islands, one an adult male, the other an immature bird, in September, 1849; one in Derbyshire, May 19th., 1839; and one near Guildford, in Surrey. In Ireland and Scotland none have been met with.

The Woodchat is by no means of a shy nature, but builds in the immediate vicinage of houses and public roads. It exhibits an antipathy against other birds, even those which it cannot prey on, such as magpies and pigeons, chasing and driving them from its haunts.

The most extraordinary fact connected with this bird, as with others of its species, is its mode of dealing with its food-already described: one has been seen fixing a yellowhammer on a thorn. It feeds occasionally on such small birds, but also on worms, caterpillars, and insects; it takes its prey on the ground, as well as in the air. I have in a previous article given my opinion as to its having beon fancied that the Shrikes' motive in fixing their prey in the curioue way they do, was to ect as a decoy. 'Credat, non ego.' 
The nest is said to be placed in the angle of the branches of a tree-a preference being given to the oak. It is composed of sticks, wool, and moss, and lined with wool and fine grass.

The eggs are described by Mr. Hoy, as being four or five in number, and varying much in marking, as well as in size. In some the ground colour is pale blue; in others dull white, with a band round the lower end of rust-coloured spots; in others the whole surface is more or less spotted with a lighter colour. Mr. Hewitson describes one from the fine collection of the Messrs. Tuke, of York, in which the spots, which are large and deep in colour-of a brown or neutral tint, are scattered equally over the whole surface. Both birds sit on the eggrs in turns.

Male; length, seven inches and a half, bill, black, notched near the tip, and depressed at the point: the feathers around its base are whitish. Iris, dark brown, the eye is surrounded by black, ending in a small patch; on the cheek is a narrow streak of white. Forehead, brownish black; head, bright olive brown; crown and nape, rich chesnut red; with a large patch of white above the wing coverts; chin, throat, and breast, white, or yellowish white; back, dusky black above, ending below in grey. Greater and lesser wing coverts, brownish black, the former faintly edged with white; primaries, dusky black, white at the base, forming a spot when the wing is closed: the first feather is less than half as long as the second; the third, fourth, and fifth, longer than the second; or, according to Selby, the second longer than the fifth, but this may be another instance of the uncertainty of the relative length of the quill feathers in some cases; the third the longest in the wing; secondaries, dusky black, white at the ends. The tail, which is graduated, has the middle feathers brownish black, with indistinct bars; the outer one on each side white, excepting one or more dark bars on the inner web; the next, white on the inner half, black on the end half, white at the tip; the next, with a white tip only. Upper tail coverts, white, sometimes tinged with yellowish; under tail coverts, the same. Legs, toes, and claws, black, sharp, grooved, and curved.

Female; length, eight inches; bill, dark brown; head, rufous, but more dull than in the male; neck, rufous, as the head; nape, dull rufous; a large patch of white above the wing coverts, but not so clear as in the male. Chin and throat, 
dull white; breast, dull white, tinged with red, particularly on the sides, where the feathers are tipped with brown, forming bars more or less in some individuals; back, rufous brown, fading into grey below. The wings expand to the width of one foot one inch; greater and lesser wing coverts, edged with rufous; primaries, dark brown, without any transverse lines; secondaries, dark brown; tertiaries, dark brown, edged with yellowish white; tail, brown; legs and toes, dark brown.

The young bird is distinguished by transverse brown lines on the back, and grey ones on the breast. 


\section{GREAT TJT.}

OXFYE. BLACK CAP. GREAT TITMOUSE. TOMTIT. GREAT: BLACK-HEADED TOMTIT. SIT-YF-DOWN.

Parus major,

Pennant. Montagu. Bewick.

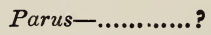

Major-Greater.

THE plague of British ornithology, useless novelties in nomenclature, according to the 'whims and oddities' of every self-styled 'Field naturalist,' may be illustrated by the example of the name of 'Parus hortensis,' or 'Garden Tit,' assigned to the Oxeye, as if it were more a frequenter of gardens than the Blue-cap, and therefore claimed a new specific name!

Mr. Macgillivray, in discussing the affinities of the genus, at the head of which, in this country at least, the Oxeye stands, gives it as his opinion, that the family of the Titmice is allied to that of the Jays; and there is certainly some sort of cousin-germanship between them.

The gay party-colour of this species-the chief of its clan - makes it a great ornament to our country. It is abundant in wooded districts; less so in others.

It is common in Russia, Holland, and Italy, and various other countries of Europe, as far north as Norway, Sweden, and Siberia, and is also said to be met with in Africa, near the Cape of Good Hope; as well as in Asia Minor, where it has been seen by my friend, Hugh Edwin Strickland, Esq. In England, Ireland, and Scotland, it is plentiful.

The Oxeye remains with us all the year round, but evidently makes partial migrations, whether caused simply by the quest of food or no, I know not. One has been met with half-way across the Atlantic.

Mr. Hewitson has well observed of the Titmice, that they are perfect mountebanks; it making no difference to them 




in their gambols and antics whether their heads or their heels are uppermost. This species, however, is less of a Harlequin, except in plumage, than some of its congeners. It is a bold and courageous bird, and bites vigorously if captured. In confinement it becomes tolerably tame; and even in its wili state will come to the window-sill for crumbs of bread. Other smaller birds frequent its vicinity without any apparent fear, notwithstanding its occasional destructive propensities, but it attacks them furiously if they advance against its nest. More than two or three of this species are seldom seen together, nor does it associate much with its generic relatives. One which Bewick kept, used to rest at night on the bottom of the cage. It is not at all a shy bird.

The flight of the Oxeye is usually short--from tree to tree, performed by a repeated flutter of the wings; but if its travel be farther it is somewhat undulated.

Its food consists principally of insects, small caterpillars hid in leaves, and seeds, which latter, if hard, it holds in its bill, and knocks against a tree till it breaks the shell--even hazel nuts it demolishes in this way. It also pulls off the moss from trees, to pry for the insects underneath, destroys bees at their hives, and makes havoc among the peas in a garden. It sometimes seeks its food on the ground, but for the most part in trees, where it exhibits much of the fantastic agility of its race. It may also be seen at times hanging under the eaves of a thatched cottage, from which it pulls out the straws it quest of concealed insect́s. It has also been known to eat smali birds, killing them by repeated taps on the head; and shews the same carnivorous propensity in the readiness with which it will pick a bone, or make a meal of a carrion.

The provincial name of this species, 'the Oxeye,' has in my opinion no reference to a derivation from the 'glaucopis Athene,' but has been given to it from its note, which, in the spring, resembles this word often repeated-a low and a high note in succession; and it has also, in addition to a chatter, another which resembles the word 'twink.' I know no bird whose voice, though monotonous, is more cheerful and exhilarating in connection with the returning spring. It begins its merry 'oxeye, oxeye, oxeye' about the beginning of March, and continues it till the middle of May. It has, however, says Mr. Thompson, been heard as early as the 23rd. and 24.th. of December, the 5th. of January, and the end of January; when, at the latter date, there was ice an inch thick 
on the pools. It is loud, so that it may be heard at the distance of lalf-a-mile. It has been likened by the country people to the words-'sit-ye-down.'

The nest is usually made in a hole of a tree or of a wall, or crevice of a rock; sometimes the forsaken nest of a crow or magpie is converted into a tenement. Not unfrequently it is placed in a pump, either used or unused, the door-way being by the orifice for the handle. Another has been known to build far up among the rafters of a house; one in a windowframe, the entrance being through the opening for the weight; and another under an inverted flower-pot. It is composed of a quantity of moss, feathers, leaves, hair, and other materials, loosely compacted. Occasionally the eggs are laid on the dust of the wood alone; and if I may offer a conjecture on the subject, possibly these cases may be when a first nest has been taken or destroyed, and the bird is in a hurry about her second brood. Since writing the above, I perceive that Montagu has made a similar sugggestion. The same site is often frequented from year to year, if its tenants are not disturbed.

The eggs, from six to eleven in number, are pure white, dotted all over irregularly with reddish brown. The hen sits closely on them, and the male keeps a station not far off, both of them equally pugnacious in defence of their progeny, the latter uttering loud cries of anger or distress, and the former hissing as she sits. The young are said, after they have left the nest, not to return to it, but to perch for some time in the neighbouring trees, and to keep together until the following spring. It is somewhat singular that the eggs of this bird resemble those of the Nuthatch, to which bird it also has some similarity in the loud tapping noise it occasionally makes against the trunks of trees, and which has been conjectured to be for the purpose of frightening insects out from under the bark.

Male; weight, about ten drachms; length, six inches and a quarter; bill, black; the upper part has a broad festoon on the edge- a characteristic of all the Titmice; iris, dusky brown, lighter on the sides and at the tip; head, black on the crown, white on the sides, sometimes tipped with yellow; neck, bluish black in front, and banded on the side with the same, and behind the white patch. The nape has a few white feathers on it, making a spot; chin, black, united to the black on the nape; throat, black; breast, yellow, tinged with 
green, divided all down the middle by a broad black line; back, olive green, bluish grey below.

The wings expand to the width of ten inches, and extend to one third of the length of the tail; underneath they are bluish grey; greater wing coverts, bluish black, edged with olive green, and tipped with white, forming a bar across the wings; lesser wing coverts, bluish, and some greenish ash-colour. Primaries, dusky bluish, edged with grey, except the first two, and tipped with bluish white, except the first three; they are margined on the inside with white, and on the outside with pale blue, excepting the third, fourth, fifth, and sixth, which are white on the narrower part, and the inner three, which are yellow: the first feather is very short, the second not so long as the third, the fourth a little longer than the fifth, and the longest in the wing, being a little longer than the sixth. Secondaries and tertiaries, the same, edged with greenish white, the white of the latter being broader; greater and lesser under wing coverts, white; tail, dusky bluish, darkest on the inner web, the outer feathers white on their outer webs more or less, and on part of the inner web towards the tip of the feather, the others margined with bluish grey; it is the latter colour underneath. Upper tail coverts, bluish grey; under tail coverts, white; legs and toes, dark lead-colour; claws, dark brown.

The female resembles the male in plumage, but the colours are less bright. Length, five inches and three quarters to six inches; head, dull black; breast, dull yellow; the black band narrower, and not quite so far extended downwards. The wings expand to the width of nine inches and a half.

The young male has the black streak narrower than in the adult bird, but continued all the way.

Lewin has recorded a curious variety of this bird, which had the upper and lower bills crossed. 


\section{COLE TIT.}

COTE TITMOUSE. COLEMOUSE.

$\underset{66}{\text { Parus ater, }}$ atricapillus,

Parus-............?
Pennant. Montage. Brisson.

Ater-Black.

THE Cole, or Coal Titmouse is dispersed over Europe, North America, and the northern parts of Asia: it is also found in Japan, according to M. Temminck. It suits itself to the genial climate of Italy, and severe Siberia; and inhabits alike Russia, Germany, Norway, Sweden, and France.

The Cole Titmouse is to be met with in every part of England-north, east, south, and west. It is by no means rare, and yet can hardly be said to be an abundant species. In the immediate neighbourhood of London it is not uncommon, and has even been seen in the great metropolis itself; but doubtless only 'en passant.' Mr. Edwards has observed it in the neighbourhood of Banff; Mr. Thompson, about Aberarder, Invernesshire; and Mr. St. John, in Sutherlandshire, in plenty; in fact, in Scotland it is a very abundant species in all the pine and fir woods; birch, oak, and alder it is also partial to. In Ireland it has been observed in the counties of Clare, Donegal, Kerry, Cork, Tipperary, Wexford, and Dublin; and therefore, there is no doubt but that it may at times be met with in every part of the 'sister island.' It is there more numerous than the Marsh Titmouse; the reverse being the case in England.

This neat little bird abides with us throughout the year, but is seen more abundantly in the winter, in consequence of partial migrations.

Though this species may be observed on almost any tree at times, the Scotch fir seems to be that in which it is most 



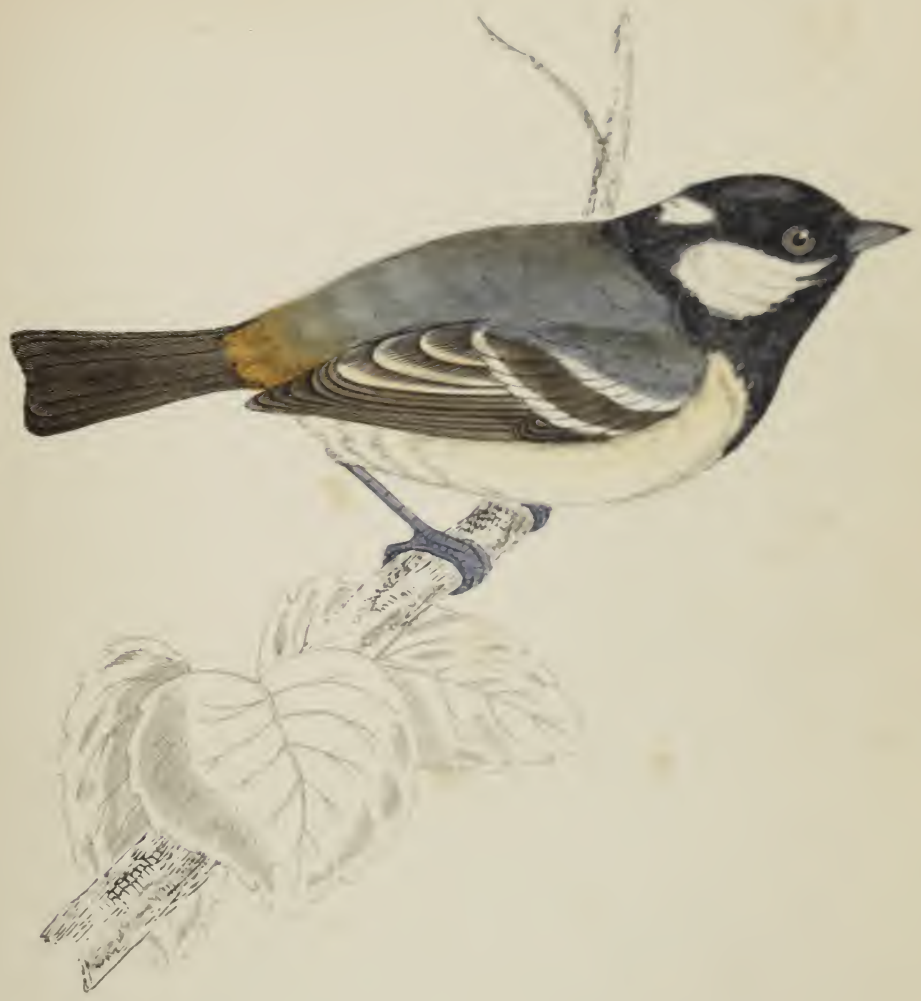



at home. It is of an apparently restless disposition, moving like 'Young Rapid,' from place to place, from helge to hodge, from tree to tree, from wood to wood, from district to district. It is addicted to woods, as supplying its food, but I have met with it in ordinary cultivated distriets. It frequently seeks its food on the ground.

It is more shy than the preceding species, or the Blue-cap. I copy the following life-like description of this interesting little bird and its associates from Mr. Macgilivray; its truthfulness I can fully attest:- 'It is pleasant to follow a tmop of these tiny creatures, as they search the tree tops, spreading all around, fluttering and creeping along the branches, ever in motion, now clinging to a twig in an invertel position, now hovering orer a tuft of leares, picking in a crevice of the bark, searching all the branches, sometimes visiting the lowermost, and again winding among those at the very tops of the trees. In wandering among these woods you are attracted by their shrill cheeping notes, which they continually emit as they flutter among the branches; and few persons thus falling in with a flock, can help standing still to watch their motions for a while.' It is also observable how suddenly, without any apparent cause, the whole troop, as if under marching orders, flit in a body from the tres, and alight elsewhere, again to go through their exercises, evolutions, and manœuvres.

Its flight is short and unsteady, produced by a continoul flutter.

The food of the Cole Titmouse consists of insects, wortos, caterpillars, and seeds. In search of the former it will pick with extreme rapidity all round in a circle, without so much as disturbing a single 'sere and yellow leat,' though porehed on the centre of its under side. It is said to be particularly fond of the berries of the woodbine, and to hold any lard seed with its feet agrainst a branch, and pock at it till it obtains the kernel. In the winter it also feeds on wheat and oats, and appears to hoard up some portion of a surumbundant supply of food against a day of scrercity. Ocenaionally it will pick a bone or other fragment with much zest.

The note, which is first heard in February, is amonowioal, and is rendered by Meyer, by the syllables 'zit, bit,' and 'aittee;' 'che-chee, che-chee' may also serve werposs it. In tho spring it is very loud, and may be heard nearly no far as that of the Oxeye-suspended for the nost part watil Augual, 
it is then renewed. When the female is sitting, at least towards the end of her confinement, she hisses at any approaching enemy, and will also bite if molested. Mr. Knapp says of this species and the Oxeye, that 'they will often acquire or compound a note, become delighted with it, and repeat it incessantly for an hour or so, and then seem to forget, or be weary of it, and we hear it no more.'

At the beginning of winter, when the plumage is new, all the feathers of the back are tipped with brownish yellow, which wears off into bluish grey in summer; and those on the lower part of the front of the neck, from being tipped with white, turn altogether black.

The nest is placed in a hole of a tree, and according to Mr. Hewitson, at a less height from the ground than that of the other Titmice, even in the hollows about the roots, sometimes in a hole of a wall, or of a bank, or in that of a mouse, rat, or mole: it is made up of moss, wool, hair, fur, and feathers. This bird, like the Oxeye, and doubtless others of its race, will enlarge a hole for its accommodation by removing the pulverised particles of wood which have partially filled or lined it.

The eggs, from six to eight in number, are like those of its fellows-white, spotted with light red.

Incubation lasts about a fortnight, the male and female sitting by turns: the young are fed principally with caterpillars. Two broods are hatched in the year, of which the first is fledged in May.

Male; weight, about two drachms and a quarter; length, four inches and a quarter; bill, blackish or dark horn-colour, lighter at the edges and tip; iris, dusky; head, white on the sides, black glossed with blue on the crown; neck, white on the sides, black near the wing, with an oblong patch of white. Chin and throat, black; breast, dull white in the middle above; below and on the sides, light buff with a tinge of green; back, bluish grey above, verging to brownish buff; the feathers are singularly long, as is the case with most of the other Titmice.

The wings underneath, grey; they expand to the width of seven inches and a third; greater and lesser wing coverts, bluish grey, the feathers tipped with white, forming two bars across the wings; primaries, brownish grey, edged with greenish grey on the outside, and on the inside with greyish white; the first feather is very short, the second shorter than the 
third, and equal to the seventh; the third, fourth, and fifth, of nearly equal length, and the longest in the wing; secondaries, the same; tertiaries, the same, tipped with dull white. 'The tail, which is slightly indented at the end, and extends a little beyond the wings, is brownish grey, the feathers margined with greenish; underneath grey, with white shafts; upper and under tail coverts, greenish buff; legs, toes, and claws, very dark lead-colour; the latter are rather thick.

The female resembles the male. The black on the head is less glossy, and does not extend so far down, and the white is less pure: the grey of the back is tinged with greenish brown.

The young resemble the female: the first feathers hare a tinge of green. 


\section{CRESTED TIT.}

CRESTED TITMOUSE.

Parus cristatus,
Pennant. Montagu.

Cristatus-Crested.

'IF any of my readers,' says Macgillivray, 'should be anxious. to know how an author may contrive to talk a great deal about nothing, he may consult the article, 'Crested Tit,' in an amusing work entitled 'The Feathered Tribes of the British Islands." I have only hereon to remark that Mr. Macgillivray is very seldom wrong, and this is not one of the few instances in which he is. Mudie certainly disproved the truth of the proverb 'ex nihilo nihil fit,' for though his stock of knowledge of any bird might be 'nil,' that had nothing: whatever to do with the 'quantum' he wrote about it; and thus he made his book.

The Crested Titmouse is an European bird, being found in plenty in Denmark, Russia, Sweden, Norway, Germany, France, Switzerland, and Poland.

In our own country it occurs more sparingly, is of very local distribution, and appears to be confined to the northern districts of one island, where, in the extensive pine forests, its shy habits and the secluded character of its chosen habitat, render its discovery a matter of rarer occurrence, than under other circumstances would probably be the case.

In Yorkshire, one is stated by Mr. Allis, on the authority of Mr. J. Heppenstall, to have been seen in a garden at Thorne, in the West Riding. In the county of Durham, one was shot on Sunderland Moor, in the middle of January, 1850. About the year 1789, a considerable flock was observed in Scotland, as also in various parts there in the autumn of 1848 ; in other seasons they have been met with, but not so 



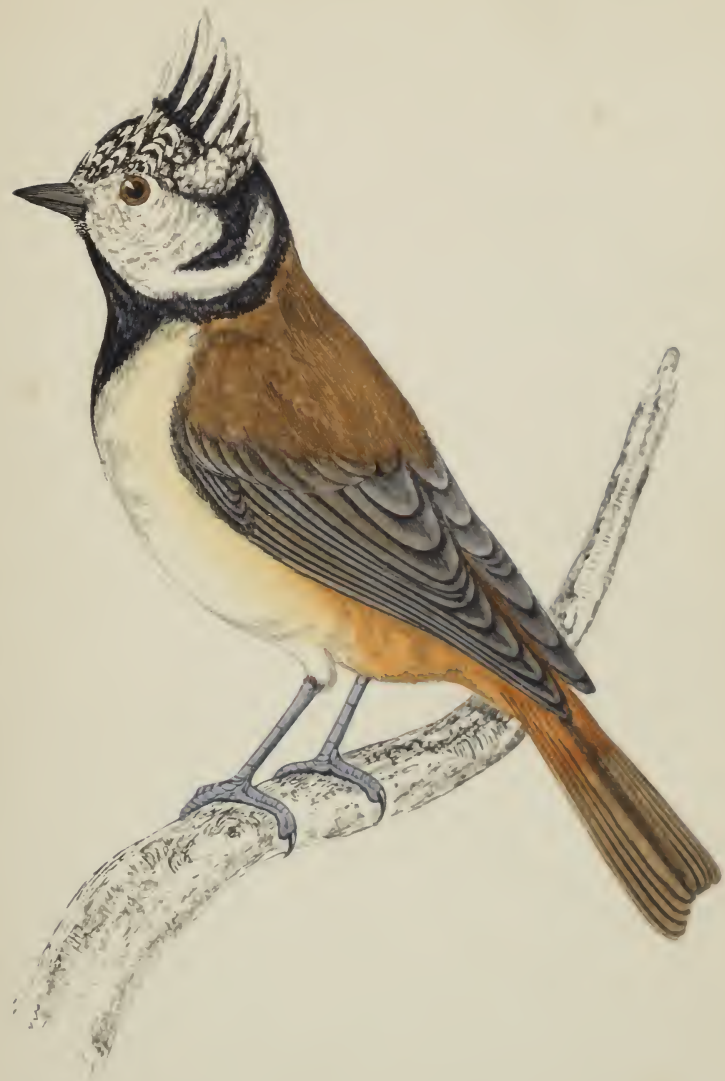



plentifully, though for the most part in small flocks. They are known to breed annually in plantations near Glasgow, and there is therefore no doubt that either the species is permanently resident in Scotland, or that it may be met with there in some part of every rear. The instances of its occurrence that have been recorded, have been in the neighbourhood of Edinburgh, and of Glasgow, the forest of Glenmore, the pass of Killiekrankie, and near the River Sper, where two were killed in 1\$36, and where on another occasion, they were seen in considerable numbers-also in Argyleshire. In Ireland none have been yet seen.

They appear to make partial migrations, or what may perhaps be better described as regular movements.

Birds of this species are said to be of retired habits, to associate but little with their congeners, to keep together in small flocks, sometimes in company with others of their kind, but to be quarrelsome one with another. In their "light fantastic,' performances, they resemble the Blue 'Titmouse. They appear to be not at all shy, and hare been observed to erect and depress the crest at pleasure. They are said to hatch two broods in the year. They are easily tamed.

Their food consists of insects, spiders, the small seeds of evergreens, and berries.

The note is described as resembling that of the Cole Titmouse, but as having a peculiar quaver at the end. Meyer renders it by the words 'ghir-r-r-kee.' The bird h-s also a chirp.

The nest, which is composed of grass, moss, or lichens, and feathers, and doubtless any soft materials, is placed in a hole of a tree-the oak being said to be preferred, as also, according to Temminck, in rocks, or in the deserted nests of crows or squirrels; probably the particular's related of the other Titmice would apply to this one also, is to its location, for a nest examined by Mr. Hewitson was thus scooped out. He writes as follows:- 'When trees are felled in the forests, their trunks ar' left standing about two feet above the ground;' (he is speaking, I should observe, of the forest of Kissingen, in Bavaria,) 'and in the decayed wood of one of these, a hols was scooped to contain the nest of which I have spokenjust such a situation as would have been chosen by the Cole Titmouse.'

I may here be permitted to remark, that Mr. Sulby's assertion, that he lad seen one of the 'Titmice engaged in hollowing out 
for itself a place for a nest in the wood of a 'decayed' tree, which has been impugned, on the ground that it could not be understood by a writer opposed to the belief of the account how the bird could scoop out for itself a hole in a 'sound' tree, is most fully borne out by all the writers on the subject who are best entitled to credit. There seems in fact among such to be no difference of opinion about it, so that it is difficult to imagine, in the presence of facts, how the contrary opinion could have suggested itself.

The eggs are from seven to ten in number, white, spotted and speckled, most so at the larger end, with light purple red.

Male; weight, about two drachms and a half; length, a little above four inches and a half; bill, black. Iris, dark brown, over it is a dull white streak towards the nape, and from behind it runs a black streak, which unites with a curved band of the same; this is succeeded by a patch of white, and this again by another black band, which comes round in front of the shoulders, until it meets the black of the throat; forehead, black and white, the feathers small and scale-like. The head is surmounted by a pretty crest of black feathers, deeply margined with white; it is of a conical shape, somewhat, not inappropriately, in the form of a Scotch cap; the feathers are shortest in front, and gradually heighten, arching forwardsthe longest is about an inch in length: at the side it is yellowish white, with a few black specks. Chin, throat, and upper part of the breast, black, in a triangular shape; beneath it is a very light dull fawn-colour, darker at the lower extremity, and tinged with rust-colour, as also the sides; back, pale brown, with a slight tinge of green.

The wings extend to the width of eight inches, and within an inch of the end of the tail; underneath they are dark grey Greater and lesser wing coverts, as the back, and margined with pale grey; underneath, light grey; primaries, secondaries, and tertiaries, as the back, but darker; the firstnamed are edged with pale grey on the inner webs; the first feather is less than half the length of the second, the third and fifth nearly equal, larger than the second, and not quite so long as the fourth, which is the longest in the wing. Greater and lesser under wing coverts, dull white, tinged with rust-colour; tail, as the wing feathers, but not so dark, and edged with light rust-colour, except the outer ones, which have narrow white edges; underneath, light grey-it is of twelve feathers; tail coverts, as the back, but lighter; under 
tail coverts, as the breast below. Legs and toes, b!uish grey; claws, brownish black.

Female; length, four inches and a half; crest, rather shorter than in the male. The black round the neck narrower, and interrupted; the black patch on the breast of smaller size.

The young are said to have a rudimentary crest even in the nest. Chin, nearly black; throat, grey; breast, dull white, mixed with grey, as are all the under parts. 


\section{BLUE TIT.}

BLUE-C.IP. BLUE-BONNET. NUN. TOMTIT. BLUE MOPE. BILLY-BITER. HICKMALL.

Parus caruleus,

Parus-...........?
Montagu. Bewick. Selby.

Ceruleus-Blne-azure.

From the window of one of my studies, that in which, 'ubi quid datur' (or rather detur) 'otî,' the 'midnight oil' is burned, by which 'illudo chartis' - in plain English, in which this work is written, I have almost daily opportunities of watching the interesting actions of this pretty little bird, which I shall accordingly describe.

The Blue Titmouse frequents the whole of Europe, except the extreme north, but is found as far as Denmark, Norway, Sweden, and the south of Russia; southwards, in Greece, Holland, France, and Switzerland, as also, it is said, in the Canary Islands; and in Asia-in Japan, according to Temminck. It is very common throughout England and Ireland, as also in Scotland, except the extren:e north.

They are not migratory, but in or before hard weather they move southwards, to escape the severity of the north, returning when that cause is removed. In the autumn, after the cares of bringing up a family are over, they often approach nearer to houses and gardens, and may be seen on almost every hedge.

These birds are of a pugnacious disposition, and frequently quarrel with their neighbours, as well as among themselves: the Robin, however, is quite master of the field. Two were once observed so closely engaged in combat, that they both suffered themselves to be captured by a gentleman who saw them. They are very bold and spirited, and are caught without difficulty in traps. They often assail their enemy, the Hawk 



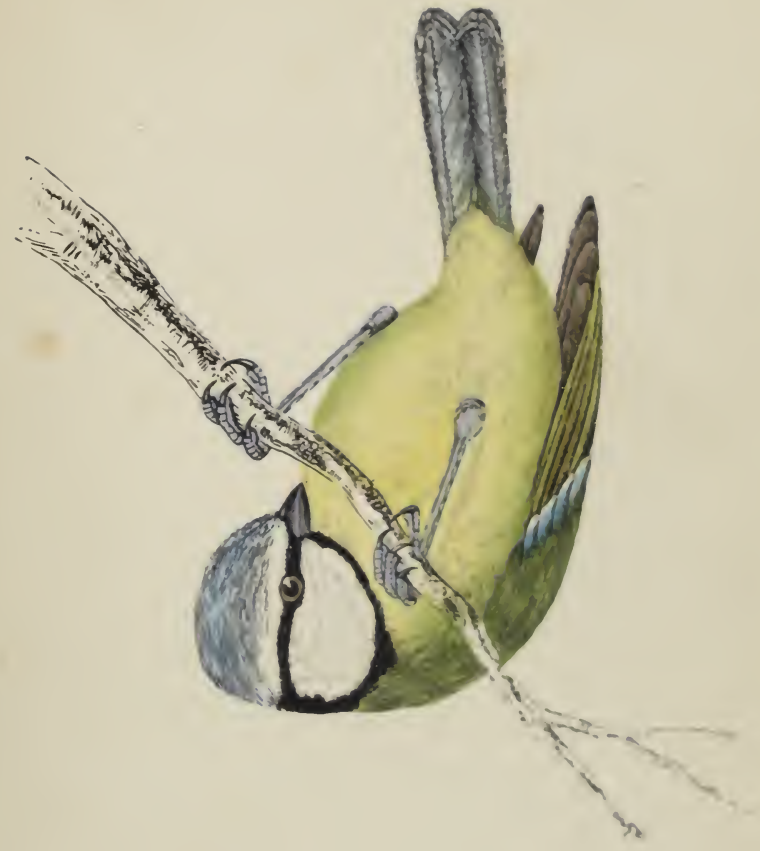



- the destrorer of their species, chasing him in the same way that Swallows do; as also Magpies, Thrushes, and any other suspicious characters; and the $\mathrm{Owl}$ they are particularly inveterate against. They bite severely if caught, and the hen bird in like manner will attack any one who molests her when sitting, in the discharge of which duty she is so devoted, that she will sometimes suffer herself to be taken off the nest with the hand; otherwise, if the nest be disturbed in her absence, she forsalkes it. One has been known to sit still while a part of the tree which guarded the entrance of her retreat was sawn off. Another, mentioned by Yarrell, which built in a box hung up against a house, kept in it while carried into the house, and did not forsake it when replaced.

When the young are hatched, both birds become very clamorous, and have even been known to fly at and attack persons approaching the nest. They pass most of their time in trees, after the manner of the other Titmice; often frequenting the same locality from day to day for some time, in search of food. 'So nimble are they', say the Rev. Messrs. Matthews, 'in this operation, that having once alighted on the stem of a plant, be it ever so fragile, and though it bends from its perpendicular until the end almost touches the roots, the bird rarely quits his hold until he finishes his examination of the leaves.' They also alight on the ground, or in a stubble field, to pick up what they may have met with there, and cling with perfect ease, for the like purpose, to the smooth bark of a tree, a wall, or a window-frame, when they sometimes tap at the window, like the familiar Redbreast, possibly looking at the reflection of themselves: frum these habits their claws are often much worn. All their motions are extremely quick, nimble, and active. In the spring they are mostly seen in pairs, in the summer in families, and later on in the year, occasionally, in small flocks. They frequent cultivated distriets, and are to be seen in any and every place where timber abounds, or hedge-rows exist, in greater or less abundance. 'They roost at night in ivy, or the holes of walls and trees, and under the eaves of thatched places, or in any snug corner. They are the most familiar, and perhaps the most lively of the genus. In severe winters they often perish from cold.

Mr. Thompson, of Belfast, in describing the extent to which these birds are capable of being tamed, speaks of one which 'from its familiarity and vivacity was most amusios. The cage was covered with close netting, which it several times 
cut through, thereby affecting its escape into the room. It then flew to the children, and having taken hold of a piece of bread or cake, in the hand of the youngest, would not forego the object of attack, though shaken with the greatest force the child could exert; indeed, the latter was so persecuted on one occasion for a piece of apple, that she ran crying out of the apartment. It was particularly fond of sugar. Confined in the same cage with this bird were some other species, and among them a Redbreast, which it sometimes annoyed so much as to bring upon its head severe chastisement. A favourite trick was to pull the feathers out of its fellow-prisoners. The young. Willow Wren before alluded to was sadly tormented in this way. A similar attempt was even made on a Song Thrush, introduced into its domicile, but it was successfully repelled. This mischievous Tit escaped out of doors several times, but always returned without being sought for.'

The flight of this species is rather unsteady, executed by repeated flappings, and if lengthened is undulated.

The Blue-cap seems to be omnivorous in its appetite, Its principal food consists of caterpillars, spiders, moths, and other insects and their eggs. In quest of these it plucks off numberless buds, but it is at least questionable whether the remedy is not even in this case far better than the disease, for doubtless the insects or their eggs, which it thus destroys, would eventually otherwise consume those very leaves, now, though prematurely, 'nipped in the bud.' 'In what evil hour, and for what crime,' says Mr. Knapp, 'this poor little bird could have incurred the anathema of a parish, it is difficult to conjecture. An item passed in one of our late churchwardens' accounts, was 'for seventeen dozen of Tomtits' heads.' ' A few peas are the extent of its depredations. Grain, especially oats, which they hold between their claws, and pick at until they twitch them from the husk, seeds and berries they likewise feast on; are fond also of animal food, and will, occasionally, so some say, destroy other small birds. They have been observed by the Rev. Messrs. Matthews, to carry food-a caterpillar, or an insect, to the young, three or four times every ten minutes. Mr. Weir communicated to Mr. Macgillivray his observations on their feeding their young, from a quarter-past two in the morning to half-past eight in the evening, and found that they did so in that period, on the average of the different hours, four hundred and seventy-five 
trmes, each time bringing one caterpillar, at others two or three, so that probably this one pair of birds destroyed six or seven hundred in the course of a single day. The destruction of the Blue-cap by the farmer or gardener is an act of economical suicide. Well has the author of the book of Ecclesiasticus written, 'all things are double one against another, and God has made nothing imperfect.'

The 'Journal of a Naturalist' records the following:- 'I was lately exceedingly pleased in witnessing the maternal care and intelligence of this bird; for the poor thing had its young ones in a hole of a wall, and the nest had been nearly all drawn out of the crevice by the paw of a cat, and part of its brood devoured. In revisiting its family, the bird discovered a portion of it remaining, though wrapped up and hidden in the tangled moss and feathers of their bed, and it then drew the whole of the nest back into the place from whence it had been taken, unrolled and resettled the remaining little ones, fed them with the usual attentions, and finally succeederl in rearing them. The parents of even this reduced family laboured with great persererance to supply its wants, one or the other of them bringing a grub, caterpillar, or some insect, at intervals of less than a minute through the day, and prohably in the earlier part of the morning more frequently; but if we allow that they brought food to the hole every minute for fourteen hours, and provided for their own wants also, it will admit of perhaps a thousand grubs a day, for the requirements of one, and that a diminished brood; and gives us some comprehension of the infinite number requisite for the summer nutriment of our soft-billed birds, and the great distances gone over by such as have young ones, in their numerous trips from hedge to tree in the hours specified, when they have full broods to support.'

Meyer renders the note of the Blue Tomtit by the words 'zit, zit;' 'tzitzee,' and 'tsee, tsee, tsirr,' which is, I think, as near as it can be approached; and shews that a comparison of it by one of my schoolfellows to the words in the Latin Grammar 'me te se, preter que ne ve,' was far from heing inapt, as in truth it is not. Macgillivray gires us 'chica, chica, chee chee,' as also 'chirr-r-r.' It has also a sort of scream - a signal of alarm, and the hen bird, when sittisg on the nest, hisses at any enemy, and spits like a kitten, rutling up her feathers at the same time. 'Many a young intruder, says Mr. Knapp, 'is deterred from prosecuting any farther 
search, lest he should rouse the vengeance of some lurking snake or adder.'

The nest, which is composed of grass and moss, and linel with hair, wool, and feathers, and is built in March or April, is usually placed in a hole of a tree, about half a dozen or a dozen feet from the ground, or even close to it. Frequently a hole in a wall is made use of, sometimes the top of a pump, though the bird may be continually disturbed, or the nest even in the first instance destroyed by the action of the handle, the entrance being the cleft for the handle to work in.

Speaking of one instance of this kind, Bishop Stanley says, 'It happened that during the time of building, and laying the eggs, the pump had not been in use; and when again set going, the female was sitting; and it was naturally supposed that the motion of the pump handle would drive her away. 'The young brood however were hatched safely, without any other misfortune than the loss of a part of the tail of the sitting bird, which was rubbed off by the friction of the pump handle.' And again, 'We knew of another pair of Titmice, which, for several days persevered in inserting, close upon the point of the handle, the materials for a nest; though every time the handle was raised, they, were either crushed or forced out, till the patience of the persevering little builders was fairly exhausted.' The most extraordinary situation, however, that I have heard or read of for the location of the nest of this, or of any other species of bird, was within the jaws of the skeleton of a man, who had been executed and hung in chains for murder. It would almost seem a realization of the fable of our childhood, respecting a somewhat similar locality therein assigned to the nests of Swallows.

Mr. Hewitson records the following, communicated to him by Mr. Heysham, of Carlisle:-'A few years ago, when upon an entomological excursion, wishing to examine the decayed stump of a tree, which was broken to pieces for that purpose, and the fragments dispersed to a considerable distance by a severe blow, a Blue Titmouse was found sitting upon fourteen eggs, in a small cavity of the root; and, notwithstanding the above severe shock, she remained immovable, till forcibly taken off the nest: sometimes, even if taken off, she will return.' Again, 'An earthen bottle was placed on the garden wall of Mrs. Chorley, of Bolton, near Lancaster; 
in this a pair of Blue Titmice built their nest, hatched their eggs, and reared their young. There was no cork in the bottle, and the birds had no other way of entrance than through the mouth; going up and down the neck of the bottle every time they carried food to their young ones, all of which, ten in number, were reared without accident, and made their escape unmolested through the neck of the bottle. When they were fairly gone, the bottle was taken down, and the old nest found within. The bottle was fifteen inches deep, and the neck one inch in diameter. I am at a loss to know how the birds could manage to ascend.' Mr. Thompson mentions a similar case in an ornamental jar; and another, communicated by Mr. Poole, in which the male used to feed the female through the neck of the jar. The nest is also often placed under the eaves of houses, the tiles of the roof, or any suitable part of an out-of-doors building; if in a tree, the outer passage leading into an inner apartment is hollowed out by the bird itself in a truly marvellous manner, as smoothly as if wrought by the hand of man: one has been known to build in the end of a disused leaden pipe.

Mr. M. Saul has narrated in the 'Zoologist,' the following most singular instance of something akin to reasoning in a case of the kind, if indeed the motive was such as he has imagined:- "Two birds made their appearance; one entered the hole, and appeared to be pecking away at the wood inside, for as it managed to separate piece after piece, it brought them to the other bird, which remained at the entrance; and this last flew away with each piece, and carrying it to a distance from the tree, dropped it on the middle of the road, as if to avoid the detection which was almost sure to follow, if the chips had been carelessly dropped at the foot of a tree in a frequented thoroughfare.'

In the 'Gloucestershire Chronicle' of June 17th., 1837, was recorded the following:- 'In the course of the present week, two men engaged in sawing into planks an oak tree at $\mathrm{Mr}$. Hunt's timber yard, near the canal basin, found in a hole in the centre the nest of a Blue Tit, containing several eggs. The nest must have been in this situation, it is supposed, for the last century, and when taken out was quite wet. The surface of the tree was entirely sound, and there was no appearance of a communication to this hidden cavity.'

The same nest is frequently repaired from year to year: the Revs. Andrew and Henry Matthews have known one 
resorted to for twelve successive years. It is said, however, that if two broods are brought up in the year, two different situations are chosen for the purpose: sometimes two pairs will quarrel for the same situation.

The eggs are generally seven or eight in number, but have been known as few as six, and as many as sixteen, and some have said even eighteen or twenty; the usual number being from eight to twelve. They are of a delicate pink white, more or less spotted, and most so at the larger end, with clear rufous brown.

Male; weight, under half an ounce; length, four inches and a half; bill, bluish grey or dusky, lighter at the edges, almost black at the tip. Iris, dark brown; there is a bluish black streak before and behind the eye, running, as it were, through it; forehead and sides of the head, white, surrounded by a collar of deep blue, which meets the streak from the eye. Crown, bright blue; a white band runs over the eyes, and encircles the head; neck in front, greenish yellow; nape, deep blue, bluish white beneath; chin, deep blue, almost black. Throat, deep blue, with a stripe of the same, almost black; breast, yellow; a stripe of deep blue runs down the middle of it; below it is nearly white. Back, greyish blue, with a tinge of green.

The wings reach to within an inch of the end of the tail, and expand to the width of seven inches and three quarters; greater wing coverts, blue tipped with white, forming a band across the wings; lesser wing coverts, light blue. Primaries, pale blue, blackish or greyish brown on the inner webs, margined with whitish; the first less than half the length of the second and eighth; the fourth and fifth about equal, and longest; the third and sixth equal, and next in length. Secondaries, bluish green, blackish brown on the inner webs; tertiaries, the same, tipped with white. Tail, pale blue, slightly wedged; some of the outer feathers brown on the inner webs and towards the tip, the outer with its margin white; tail coverts, lighter than the back, and faintly mottled with whitish. Legs and toes, bluish grey; claws, brownish.

The female resembles the male, but is a little smaller, and her colours not so bright. Weight, three drachms; the breast has the blue stripe not so well defined, and less prolonged, and both it and the yellow fainter and less pure.

The young resemble the female, but the colours still duller, and tinged with grey. Bill, light yellowish brown; the black 
streak is indistinctly defined, being dull light bluish grey: over the eye a dull yellow streak running round the head. Forehead, dull yellow; sides of the head the same; crown, dull light bluish grey; the ring on the neck the same; throat, dull yellow. The streak down the breast also obscure in the young male, and wanting in the female: the breast itself dull yellow, tinged with grey on the sides, and lower down; back, light green, with a grey tinge. Greater wing coverts, grevish blue, tipped with yellow; lesser wing corerts, greyish blue; primaries, greyish blue, edged narrowly with greyish white; secondaries, the same, edged broadly with light green, and tipped with yellowish white; tertiaries, greyish blue. Toes, dull bluish grey; claws, light jellowish brown.

At the first mouic in August the bill is dark horn-colour, edged with white; the sides of the head and the mark round the crown are yellow, mottled with white; the crown greenish, interspersed with the coming blue feathers, and tho dark streak through the eye and collar dusky. There is a very great and striking dissimilarity in the sizes of different individuals of this species, so much so as almost to make one fancy that they might prove two species, and not one. Individuals vary also in brightness of colouring; and at the time of moulting, in the autumn, they often become of a curious dull and dingy colour, as if in very ill health.

A white variety of this bird was observed at Northrepps, in the county of Norfolk, in the year 1S19; and another is recorded by the Revs. Andrew and Henry Matthews, in their 'Catalogue of the Birds of Oxfordshire and its neighbourhood,' published in the 'Zoologist,' 'in which all the feathers of the wing were more or less marked with large brown spots.' 


\title{
MARSH TIT.
}

\begin{abstract}
MARSH TITMOUSE. BLACK-CAP. SMALLER OXKYE. WILLOW-BITER. JOE BENT.
\end{abstract}

Furus palustris,

Parus-...........
Pexnant Hovitace. Grelin.

Ir Europe this is a perennial inhabitant, in Russia, Siberia, Norway, Denmark, Sweden, France, Holland, and Italy; and doubtless in all other countries of the continent. Meyer says that it is also found in North America. and the northern parts of Asia.

In Yorkshire, as in every county in England, the Marsh Titmouse may be met with, here in greater, and there in less plenty than the Cole Titmouse-not that it is by any means to be called a very common species. One of these birds was shot on the river which runs through the town of Louth, as I am informed by the Rev. R. P. Alington, in the winter of 1849. In Scotland, except in the extreme north, it occurs as in England. In Ireland it seeins to be very unfrequent, but not to be partial in its distribution.

This species remains with us throughout the year. 'It is perhaps even less shy than the Cole Titmouse, and may easily be tamed. Though its name would lead one to suppose the contrary, it is not by any means exclusirely confined to marshy districts, but may be found occasionally in any situation, but principally by the wooded margins of streams and ponds, preferring low trees and brushwood to hedgerow timber, the wood, or the forest. Itș habits and actions are those of the other Titmice. 'They dwell torether,' says Linnæus Martin, 'in considerable numbers, and are perpetually in motion, going 


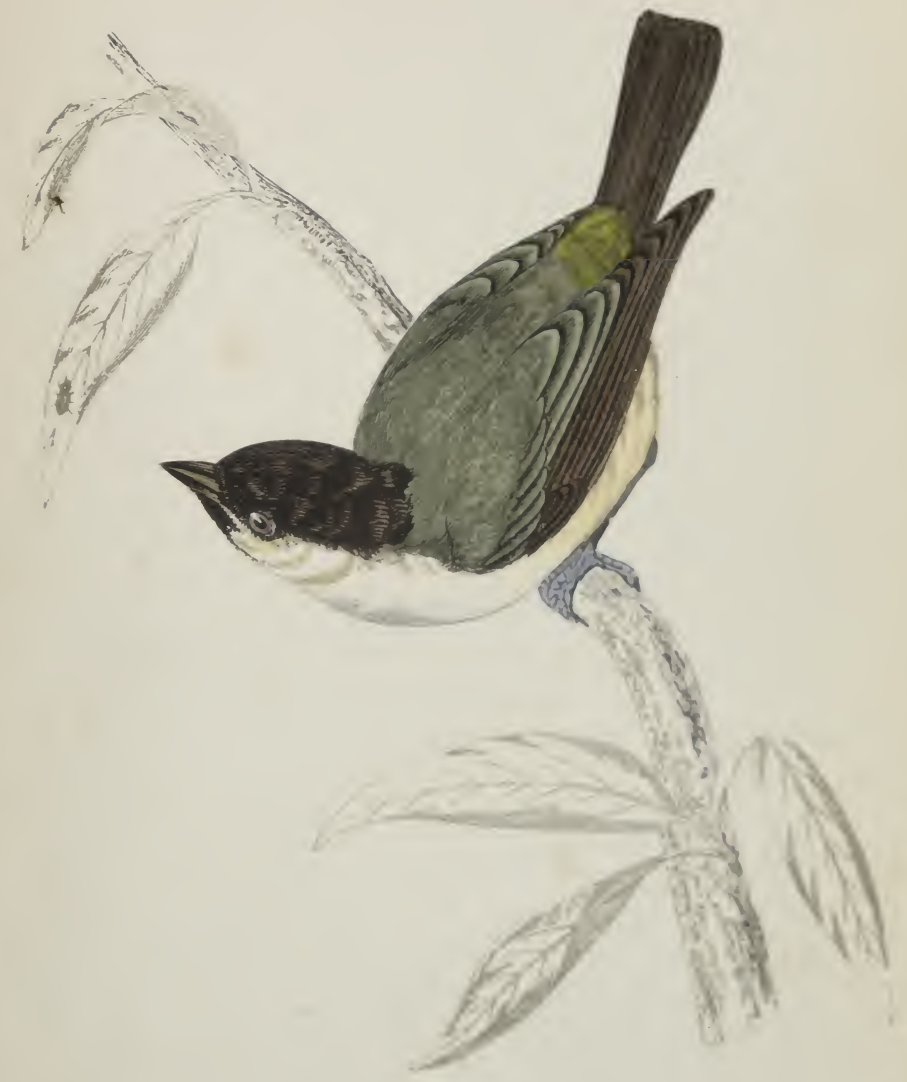



in and out of their nests, feeding their young, flying of in search of food, or seeking for it in the crevices of the neighbouring trees. It is truly gratifying to witness their sprightly gambols, and the entertaining positions into which, as it were, in the very exuberance of spirit, they are continually tirrowing themselves.'

In winter these birds collect in small flocks, the individuals of which pair together in the spring; they are said to lay up a little store of food against the former season, and to roost generally in trees at night, hiding themselves in small holes. The male is believed to choose a partner for life, and occasionally to feed the female, which receives the food in the same shivering manner that a young bird does; and the female displays the same disinterested guardianship of her family as the others of the Titmice. Both parents shew a very affectionate disposition towards their family, and the members of the latter to each other; so that if one is caught, and placed in a cage, the others come to it, and may be captured likewise. Let it be hoped, however, that no reader will act upon this information, but leave the Marsh Titmouse to the liberty of which, as just shewn, it makes so good a use. Small flocks of six or eight may be seen together in the autumn-probably the members of the family which the summer has produced.

Its flight is rather quick and undulated.

Its food consists principally of insects, but when they are not to be had in sufficient plenty, it realily puts up with seeds, both of wild and garden plants; and will, if need be, pick at a carrion. It is said to be fond of the seeds of the thistle and the sun-flower, to have a 'penchant' for bees and wasps, and not, in case of necessity, to turn away from an oat rick. It has been known to eonsume more than half its own weight of food in a day. The young aro fel with caterpillars; Mr. Weir observed the old birds to feed them about twenty times an hour: he observes, "The female came within fifteen or twenty yards of me, but the male was shy, and remained at a considerable distance.'

'The note resembles the syllables 'che-chee, che-chee;' as also, according to Macgillivray, 'chica-chica-chee; and to Meyer, 'tzit, tzit, dea-dee,' as also, 'witgee,' uttered maxy times in succession. He thinks that the name Titmouse has perhaps been derived from the note-a sharp sort of chirp quickly performed, gay and rather rich, though unmmsingl. 
It has also a variety of chatters, a shrill cheep, and a 'twink.'

It may be heard even in the winter, if a mild season.

Mr. Hewitson, on the authority of Montagu, says that considerable pains is taken by this species in hollowing and scooping out a suitable cavity for its nest, as it works, always downwards, in forming a passage to a larger apartment at the end. Montagu has observed it carrying away the chips to some distance in its bill. The nest is described by the former as being somewhat more carefully made than that of the other Titmice. It is formed of moss, wool, grass, willow catkins, horse-hair, and any other soft materials, and is placed in the hollow of a tree, such as is afforded by the head of a pollarded willow, whose decapitation has been followed, as a necessary consequence, by decay.

The eggs are from five to seven, or eight, nine, or even twelve in number, of a rotund form, white, spotted with light red, and most so at the thickest end, the other being free from them: they are hatched in about thirteen days. The young do not fly until the end of July, and even nests and eggs have then been found, but it is possible that these may have been second broods.

Male; weight, a little under three drachms; length, four inches and a half; bill, black; iris, dark brown; head on the sides, greyish white, on the crown black, slightly tinged with brown; neck, the same behind, greyish white on the sides, and greyish black in front, the feathers tipped with greyish white; chin, as the crown; throat, the same as the front of the neck; breast, brownish white, with a tinge of yellow; back, greyish brown tinged with green. Greater and lesser wing coverts, as the back; primaries, dark brownish grey, margined with yellowish grey; the first is half the length of the second, which is about the same length as the ninth, the fourth the longest, the fifth and sixth almost as long, and nearly equal, the third equal to the seventh. Secondaries, the same, but margined with yellowish brown; tertiaries, the same; larger and lesser under wing coverts, brownish white; tail, as the primaries, the outer feathers having the outer webs paler; it is nearly even at the end; underneath it is brownish white; upper tail coverts, as the back; legs, toes, and claws, bluish black.

The female only differs from the male in being more dull in colour, especially in the black parts, which are more tinged with brown. 
'The young, when fully fledged, differ from the advilt only in having the tints more dull. Bill, black; iris, dusky brown; head, blackish brown,-dull pale yellowish grey on the sides; throat, blackish brown, the feathers tipped with yellowish grey; breast, dull pale yellowish grey; back, light greyish brown, slightly tinged with green. Primaries, secondaries, and tertiaries, dusliy; tail, dusky; toes, light blue; claws, dusky greyish blue. 


\section{LONG-TAILED TIT.}

LOYG-TAILED TITMOUSE. MIUM RUFFIN. BOTTLE TIT. LONG-TAIL PIE. LONG TOM. BOTTLE TOM. POKE PUDDING. LONG POD. HUCK-MUCK. LONG-TAILED MIAG. MUEFLIN. LONG-TAILED MUEFLIN.

I BENLOYN GNYFFONHIR, OF THE ANCIENT BRITISH.

Parus caudatus,

" longicaudatus, Mecistura vagars,

Parus-............?
Pennant. Montagu. Brisson.

LEACH.

Caudatus-Tailed.

'How pleasant it is,' says Macgillivray, 'to gaze upon these little creatures, streaming along the tops of the tall trees by the margin of the brook, ever in motion, searching the twigs with care, and cheeping their shrill notes as they scamper away, one after another.' This is from the life. Thus have I often seen them jerking off from tree to tree, or branch to branch, and pleasant they are to behold. Mr. Hewitson also well observes, 'I have never met with the Long-tailed Titmouse so common, or seen them so often, as to destroy the novelty and interest which their appearance never fails to excite, as they come flitting across my path in rapid succession.'

The Long-tailed Titmouse inhabits the whole of the continent of Europe, as a permanent, but moveable resident, from Siberia and Russia, to Holland and Italy. In Asia, M. Temminck records it as a native of Japan; and Latham of the West Indies.

This species is common in this country, frequenting plantations, woods. thickets, shrubberies, and tall hedges. It is to be met with throughout England and Wales, as also in Ireland, 



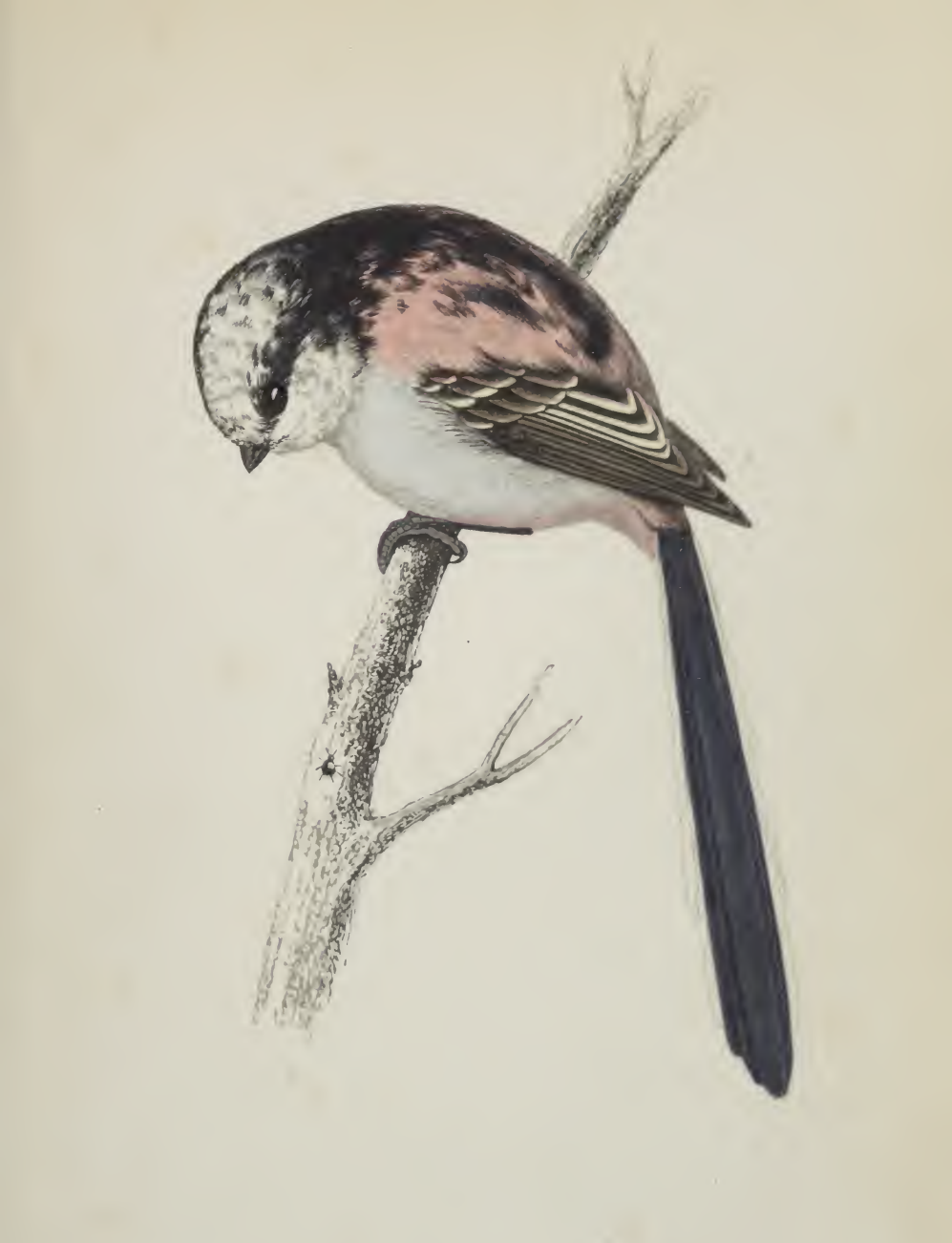



but not very numerously there, and in sicotland in abundance, except in the northern parts. It remains with us the whole year.

The habits of this little bird resemble those of the rest of the family, of which it is the miniature; but it is, if possible, still more active, from the very first peep of day till the sun has again gone down, being incessantly occupied in yuest of food. The young consort with their parents during the first autumn and winter, and when roosting at night, huddle up all close together, as if one mass of fuathers, probsbly for the sake of warmth. In April the different members of the famils separate, to become in their turns the founders of other branches. While engaged in nidification, they attack with the utmost fearlessness any birds that approach their nest, even if three or four times larger than themselves. 'They do not appear to be rery tameable, though they shew but comparatively little fear of man in their wild state.

In flying, as they do from tree to tree in an irregular string, these little birds have a singular appearance; they seem also so light, and, as it were, overburdened by the length of their tails, that but a moderate gust might be thought to $b=$ too much for them. 'Constantly in motion,' says Meyer, from tree to tree, and flying in a straight line with much rapidity, they remind the spectator of the pictured representation of a flight of arrows.' 'Away,' says Mr. Knapp, 'they all scuttle to be first, stop for a second, and then are away again, observing the same order and precipitation tho whole day long.'

Their food consists entirely, or almost entirely, of insects and their larræ: seeds have been found in them, but so very few, that possibly they may, I think, have been swollowed accidentally with their other food.

That which Shakspeare truly describes as so pleasing in a woman, a 'small voice,' goes to the heart of the naturalist when nttered by the tiny bird belore us. It is the very embodiment of gentleness, weakness, and tenderness. It bas however, a second note-a louder twitter, and a thind ehirp, still hoarser. Macgillivray deseribes it by 'twit, twit,' and 'churr, churr,' and Meyer by 'te, te,' and 'tse-re-re:' others by 'zit, zit.' In the spring it even attains to somew bat of a low and pleasing, though short, song.

Nidification commences early in March.

The nest of this little bird, the situation of which is 
resorted to frequently from year to year, is beautiful, and I may say wonderful. It is a hollow ball, generally nearly oval, with only one orifice; some have said two, to account for the location of the tail, which is said to project through one of them; and Mr. Hewitson describes one that he saw which had two openings, leaving the top of the nest like the handle of a basket, but such must be exceptional or accidental cases. A French writer has explained that one orifice is intended for a front and the other for a back door! Mudie writes as follows:- They, in the case of two apertures, sit with the head of the male out at the one, and the tail of the female out at the other, so that both the apertures are partially closed, and the male is ready to start out as soon as there is light enough for hunting,' 'the male going out first in the morning, and the female last at night!' (Bewick says that the male has his head and the female her tail out of the one hole.) There being, however, in reality, but one orifice, through which they 'have their exits and their entrances,' will perhaps be a sufficient answer to both these theories. How the birds manage is another question, but certain it is that it is so. The nest is so admirably adapted, by the lichens or moss it is so elegantly covered with, to the appearance of the tree it is built on, as to make it oftentimes very difficult to be detected. It is generally placed between the branches of a tree, unlike those of the other Titmice, and frequently not far from the ground, or firmly fixed in a bush; is composed of moss, small fragments of bark and wool, compacted with gossamer-like fibres, and the cocoons of spiders' eggs, and the chrysalides of moths, and plentifully lined with feathers, so much so, as in some parts of the country to have acquired for it the 'sobriquet' of 'feather-polee; one, on their being counted, was found tc contain two thousand three hundred and seventy-nine. It is, as may be supposed, waterproof and very warm.

It is from five to seven inches long, by three or four wide, and the aperture about an inch and a half in diameter, and the same distance from the upper end. The elasticity of the materials of the nest tend to keep it rather closed. One has been seen in which a feather of the lining acted as a valve or door, but I think that this was probably accidental. The fabrication of the nest occupies from a fortnight to three weeks; and the credit of the handiwork belongs to both the male and female; she not being, as has been asserted, the 
sole architect. They both, as it were, knead it during its formation, with their breasts and the shoulders of their wings, aided by every variety of posture of the body.

The eggs are from ten to twelve in number, and occasionally, but very rarely, as many as sixteen. In refurence to these cases, Mr. H. Horsfall, of Calverley House, near Bradford, Yorkshire, writes as follows in the 'Loologist,' page 2567:- I suspect where the greater number is found, there will be more than one pair of birds attached to the same nest. I have known several instances where a considerable number of birds have had one nest in common: in one instance there were nine.' They are sometimes entirely white, or with the spots almost obsolete, but generally spotted a little with pale red. They are, as may be imagined, very small, being about the size of a pea.

The whole plumage of these birds is soft and downy, and, being much puffed out, gives them even a larger appearance, small as that is, than their real size; and the neck appears, as it were, covered by a cape from the head. In summer, the white is purer and the wings more brown. Male; weight, about two drachms; length, about fire inches and a half; bill, glossy jet black, and nearly hid by the bristly feathers, white with brown tips, which surround its base. Iris, hazel; over the eye is a narrow black stripe, said to disappear in old birds; head on the sides, forehead, and crown, neck on the under part, and nape, greyish white; throat, as the head; breast, greyish white, tinged on the sides with rusty roseate, shaded with purple or vinous. Back, dull roseate; on the upper central part of it is a triangular patch of black, a continuation of the junction of the black stripes orer the eyes.

The wings are less in length than the tail by two incles and a quarter; the first quill is half an inch lorig, the second shorter than the third, the third than the fourth, the fourth than the fifth, which is the longest, the nimh noont the same as the second. Greater wing coverts, browmish black: lesser wing corerts, brownish black, tippod with white; primaries, brownish black; the first feather is very short, tho second longer, the third still longer, the foirth a litule longer, the fifth the longest in the wing; underniatly they are grey, with silvery edges; secondaries, the sams, broally edged with white; tertiaries, the same, edged with white; larger and lesser under wing coverts, white. The tail, wheh 
is full three inches long, and resembles that of the Magpie, has the three middle pairs of feathers very long and black, the next three pairs half an inch shorter each than the other, black on all the inner webs except the end, which is as white as the outer web; on the third feather the white extends only half way down. Upper tail coverts, black, running into the red of the back; under tail coverts, greyish white tinged with roseate, or rusty red; legs, toes, and claws, dull black.

The female resembles the male in plumage, but the black streak over the eye is wider.

The young, which are fledged about the end of June, attain the complete plumage in November; until then the bill is pale reddish, which gradually darkens; iris, lighter than in the old bird. Head on the sides, mottled with a streak of dusky brown on each feather; crown, white; neck on the sides, as the head, on the front in the second plumage, greyish white with small light brown spots, and behind as in the adult. Breast, white, afterwards reddish white; back, as in the adult bird, but the colour less pure, and more brown; at first nearly entirely so. Wings, as in the adult; secondaries, white on the outer edges. The tail has the outer webs of the three side feathers, and part of the inner webs of the two outer, white; in the second plumage it becomes the same as in the adult bird; under tail coverts, brownish red. Legs and toes, as tne bill.

Sir William Jardine describes one which had the crown and under parts white, but all the rest of the plumage black, tinged only on the scapulars with rose red; Montagu others, as ulack on the whole of the upper part of the neck, and with an obscure dusky band across the breast; and Bewick one, in which the black band through the eyes was wholly wanting, the back of the neck black, and the sides reddish brown, mixed with white. 



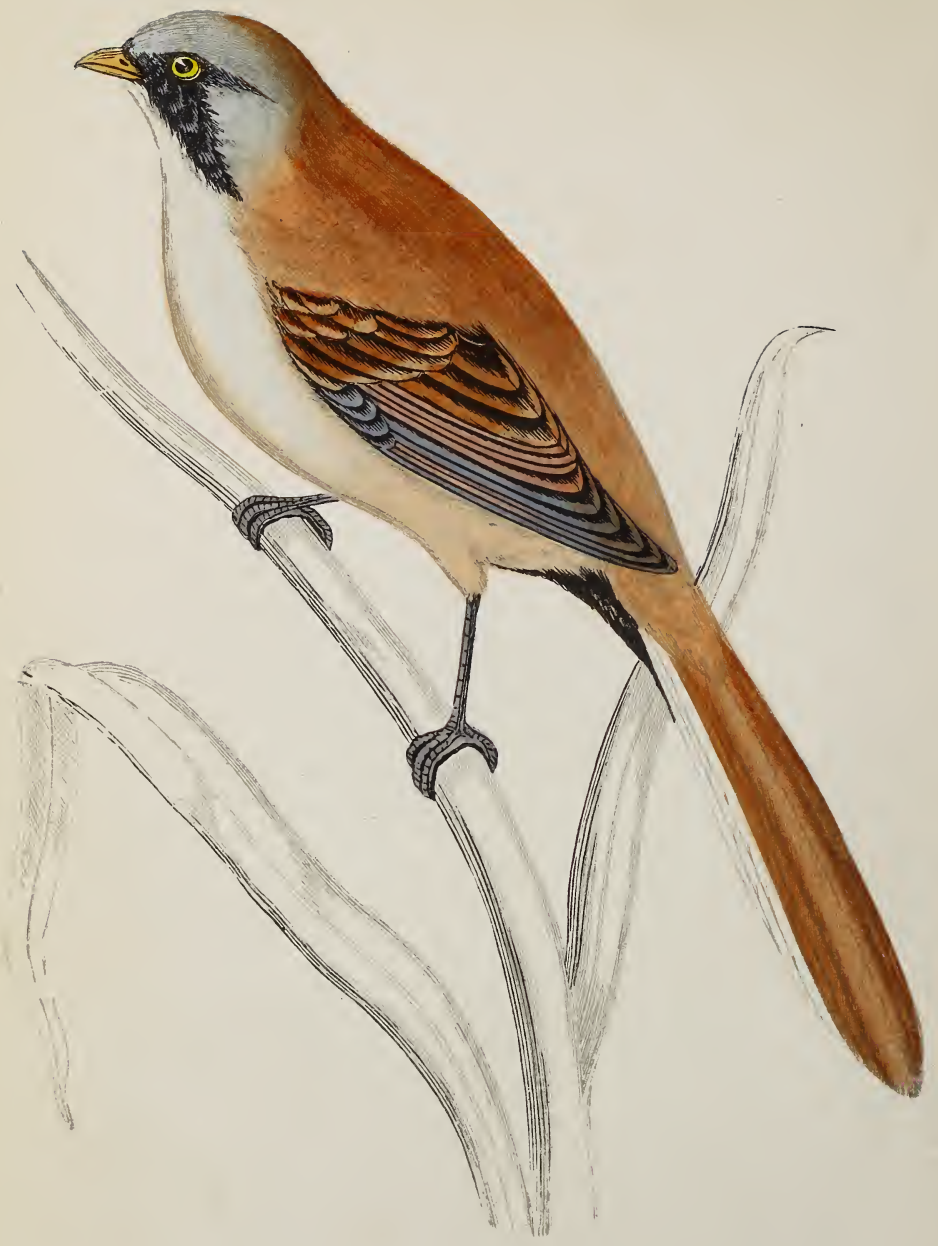

BEARDED TIT. 




\title{
BEARDED TIT.
}

\begin{abstract}
BEARDED TITMOUSE. LEAST BUTCHER BIRI). PINSOOK. BEARDED PIYNOCK. REEI) PIIEASAYT.
\end{abstract}

I BARFOG, OF THE ANCIENT BITISII.

\author{
Parus barbatus, \\ ". bicrmicus, \\ Culamoplilus biarnictos,
}

Birieson.

Lixs.es. GuFir. Jr:xxs. Gould.

$$
\text { Parus-........ ? Burbatus-Bearded. }
$$

IT has long been my opinion that this bird partakes somewhat of the characteristics of the Shrikes, as well as of the Titmice. In confirmation of this view, I would refer to Bewick's figure, which is, I think, strikingly corroborative of it, as also to the name of Least Butcher Bird, given to it so long ago as the time of Edwards, and that of 'laniellus,' by some modern writer.

The Bearded Titmouse is a native of Europe, feing abundant in Holland, and also met with in France and Italy. It is likewise found in Asia, on the borders of the Bluck Sea and the Caspian Sea, and doubtless in numberless other parts.

In Yorkshire, a bird of this species was abeorved at Kirkleatham, in Cleveland, in 1841 or 1842 . The only other account apparently of its occurrence, is on the astbority of Mr. W. Eddison, who, in a communication to Mr. Allis, ppeaks of it as not very uncommon near Huddentield. and san that he has seen three or four living specimens. In some of the southern counties of England it is to he met with: the following localities have, at least hitherto, boon froquentod by it:- Hoveton, Hickling, and Horsey, in Norfolk; Whittlona, 
in Cambridgeshire; the Lincolnshire fens; the Suffolk coast; Barking, and between Erith and London, and other parts down the river, in Essex; near Cowbit, in Lancashire; Winchelsea, in Sussex; the banks of the Thames upwards towards Oxford; one near Elston, in Cornwall, in January, 1846; and formerly near Gloucester. In Surrey, near Godalming; in Kent, down the river; in Hertfordshire, near Tring, and near Hitchin, both in December, 1848, and therefore probably the same flock. In Scotland it is unknown. In Ireland, one was taken on the banks of the Shannon.

Marshy situations, as producing the reeds which furnish its food, are naturally frequented by this most exceedingly elegant species.

In their attitudes, while feeding, these birds resemble the other Titmice; if disturbed, they drop down among the reeds, which they afterwards climb up again with nimble dexterity; 'apropos' of which, I must not forget to mention that the origin of the name 'Titmouse' has been conjectured to be from the mouse-like stealthy creeping of the family around the branches of trees. Their flight is in general only just sufficiently protracted to clear the summit of the reeds, on the tops of which they also alight to feed on the seeds. In the autumn and winter they go in small flocks of two or three families. They are easily tamed.

Their food consists of seeds, principally of the reed, insects and their larvæ, and minute snails.

The note somewhat resembles that of the Blue Titmouse, and has also been likened to the syllables 'ping, ping;' possibly one of its names, the Pinnock, may be hence derived. It is said to be very soft, musical, and clear in its tone. A contributor to Loudon's 'Magazine of Natural History' thus described it in giving an account of a flock which he had had an opportunity of observing:- - They were just topping the reeds in their flight, and uttering in full chorus their sweetly musical note; it may be compared to the music of very small cymbals; is clear and ringing, though soft, and corresponds well with the delicaey and beauty of the form and colour of the bird. Several flocks were seen during the morning. Their flight was short and low, only sufficient to clear the reeds, on the seedy tops of which they alight to feed, hanging, like most of their tribe, with the head or back downwards. If disturbed, they immediately descend by running, or rather by dropping. Their movement is rapid along the 
stalk to the bottom, where they creep and flit, perfectly concealed from view by the closeness of the covert, and the resembling tints of their plumage.'

Nidification commences towards the end of April; one nest, however, was found in 1846, that spring having been very mild, which must have been built the latter end of March.

The nest is placed among tufts of grass on the ground, and is formed of dry stalks and blossoms of grass, reeds, and sedge; the finer ones on the inside, and the coarser on the outside.

The eggrs, which are from four to six, rarely saven in number, are of a white or faint pink colour, irregularly speckled, spotted, and streaked with reddish brown, with a tinge of purple.

Male; length, about six inches; bill, clear orange; the upper part the longest; between it and the eye and downwards beyond it, is a jet black moustache, ending in a point. The bird seems to have the power of puffing out these feathers when excited. Iris, clear orange; forehead, head, and neck, delicate grey; nape, yellowish brown, tinged with orange; chin, throat, and breast, pure white, sometimes tinged with grey, verging into yellowish or faint pink below, and on the sides to salmon-colour. Back, fawn-colour, as the nape.

The wings reach to within two inches and a quarter of the end of the tail; greater wing coverts, fawn-colour; lesser wing coverts, black; primaries, dusky greyish brown, with narrow white outer edges; the first feather very short, tho second and fifth equal, the third longer, the fourth the longest. Secondaries edged with orange brown; tertiaries, buff white on the inner webs, on the outer black, broadly edged with dark fawn-colour. The tail, which is wedge-shaped, has the four middle feathers fawn-colour, the outer one black at the base, and pale reddish white at the end; the two nert white on the outer webs, and pale buff on the imner, whitening towards the tip; the middle pair are the longest, the others graduated, each shorter than the other. Upper tail coverts, fawn-colour; under tail coverts, jet black; legs, toes, and elaws, black.

The female is rather less than the male. Ietween the bill and the eye is a dusky spot; the moustache is white, the feathers elongated as in the male. Head on the crown, brown, more or less dark, spotted with black on the poll; neck, brownish white on the sides; chin, throat, and breast, 
brownish or yellowish white, paler than in the male. Back, dark fawn-colour, streaked on the middle with dusky on the shafts of the feathers. The tail is not so long as in the male; under tail coverts, as the breast.

In the young the moustache is marked by a narrow black line; breast, fawn-colour; back, black, which wears off by degrees. Wings patched with black, which gradually wears off; the tertiaries want the white inner webs; tail patched with black, which gradually becomes less.

ENT OF VחI I. 
$$
\text { , }
$$ 



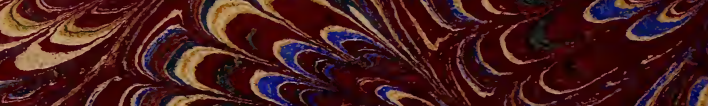

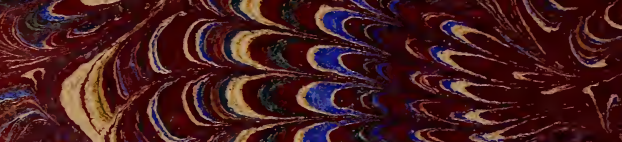
$a_{6}$

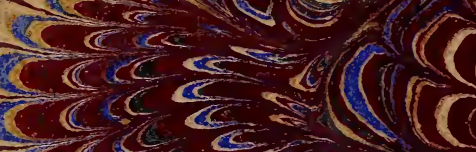
4) $c<1$ cer

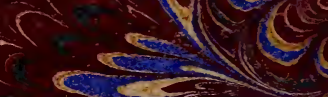
16 आccers

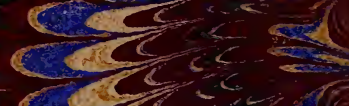
बreces

ace

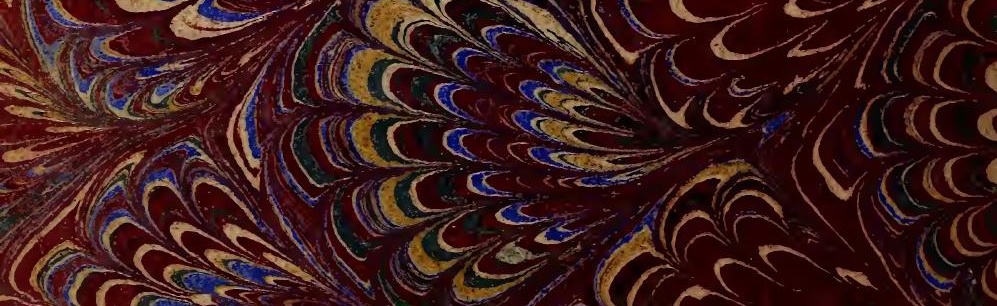
(C) (r)

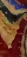



1) Whoth

1

4. 30 .

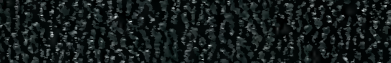

W.

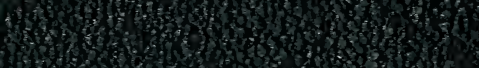

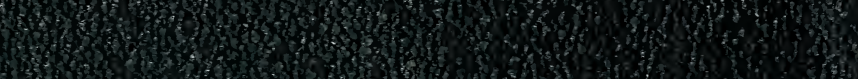

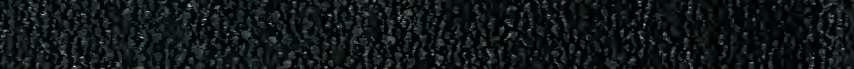
3. 6. 15.

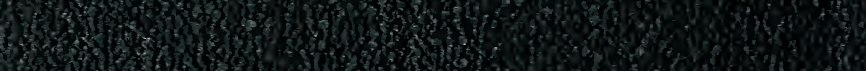

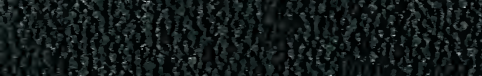

How

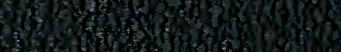

76)

(3) W. 20. W.

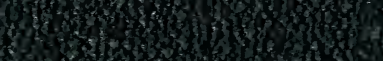
Kontor.t.

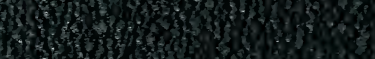
Whos

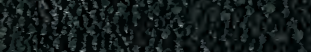
40.74 .

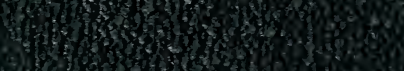
W. 3.

(19)

b.

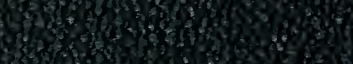

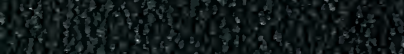
How 